\title{
Leaching Impact on Compressibility and Shear Strength of Undisturbed and Cement-treated Champlain Sea Clay
}

\author{
by \\ Mohammad Afroz \\ BSc. Civil Engineering \\ Bangladesh University of Engineering \& Technology, 2005 \\ Dhaka, Bangladesh
}

\author{
A thesis \\ presented to Ryerson University \\ in partial fulfillment of the \\ requirements for the degree of \\ Master of Applied Science \\ in the program of \\ Civil Engineering
}

Toronto, Ontario, Canada, 2019

(C) Mohammad Afroz, 2019 


\section{AUTHOR'S DECLARATION FOR ELECTRONIC SUBMISSION OF A THESIS}

I hereby declare that I am the sole author of this thesis. This is a true copy of the thesis, including any required final revisions, as accepted by my examiners.

I authorize Ryerson University to lend this thesis to other institutions or individuals for scholarly research.

I further authorize Ryerson University to reproduce this thesis by photocopying or by other means, in total or in part, at the request of other institutions or individuals for scholarly research.

I understand that my thesis may be made electronically available to the public. 


\title{
Leaching Impact on Compressibility and Shear Strength of Undisturbed and Cement-treated Champlain Sea Clay
}

\author{
Master of Applied Science, 2019 \\ Mohammad Afroz \\ Department of Civil Engineering \\ Ryerson University
}

\begin{abstract}
This research investigated the impact of leaching on the compressibility and shear strength properties of undisturbed and cement-treated Champlain Sea clay. A total of five undisturbed clay samples were leached with distilled water in the laboratory to reduce the salinity from initial values ranging from 9.5 to $15 \mathrm{~g} / \mathrm{L}$ to the salinity values of $2.75,1.45,1.03,0.55$, and $0.35 \mathrm{~g} / \mathrm{L}$. A series of geotechnical tests were conducted on these samples at different salinity levels, including constant rate of strain consolidation tests, consolidated isotropic undrained triaxial compression tests, and vane shear tests. The experimental results showed that leaching leads to an increase in the compressibility and a reduction in shear strength of undisturbed Champlain Sea clay. The experimental results revealed that cement, mixed at a dosage of $50 \mathrm{~kg} / \mathrm{m}^{3}$, can significantly decrease the compressibility and increase the shear strength of Champlain Sea clay. A leached cement-treated sample exhibits a relatively higher compressibility than that of unleached cementtreated one. An increase in compressibility was also observed as salinity declines for the cementtreated samples. Moreover, a cement-treated sample at a lower salinity level displays slightly a higher shear strength compared to that of a cement-treated sample at the original salinity level.
\end{abstract}




\section{ACKNOWLEDGEMENTS}

Firstly, I would like to express my sincere gratitude to my advisor Prof. Dr. Jinyuan Liu for the continuous support of my MASc study and my research, for his endurance, inspiration, and vast knowledge. His guidance helped me during the research and writing of this thesis. I could not have imagined having a better advisor and mentor for my MASc study.

I also want to thank Dr. Tareq Salloum of OPG, Dr. Laifa Cao of WSP, and Mr. Naresh Gurpersaud of the Keller Foundation Ltd for their time, support and guidance. I would also like to thank National Sciences and Engineering Research Council of Canada, Ontario Centre for Excellence, Keller Foundations Ltd, and Golder Associates for the financial support of this research. The permission of OPG in using the clay samples is greatly appreciated.

Lastly, I would like to acknowledgement the contributions of many students and researchers,

including Mr. Ali Ahmed, Mr. Mouley Youssef, Mr. Kun Yong, and Mr. Allan Gasper of Ryerson University for various laboratory tests. 


\section{Table of Contents:}

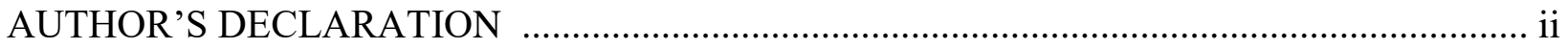

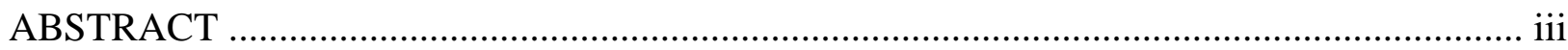

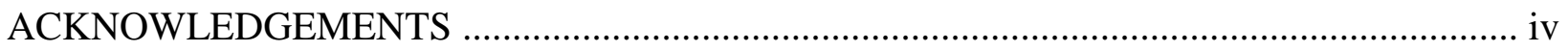

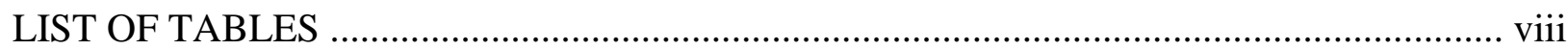

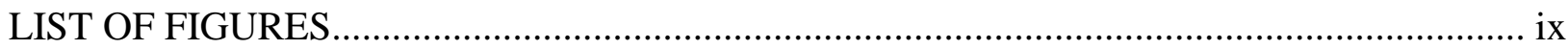

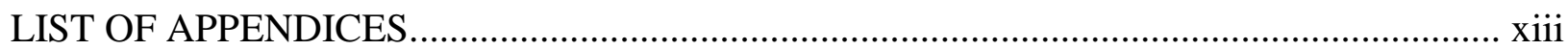

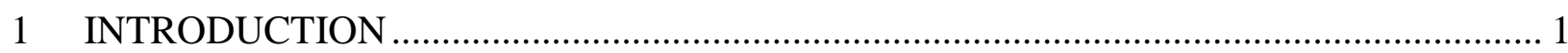

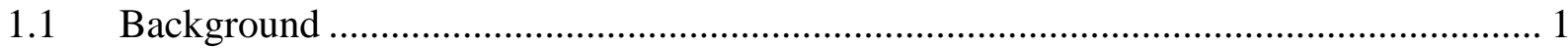

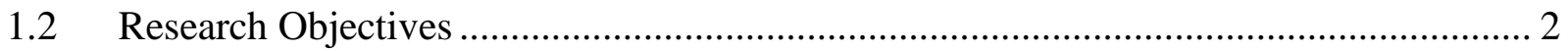

$1.3 \quad$ Research Methodology …………………………................................................. 2

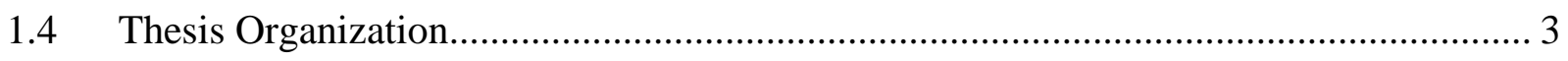

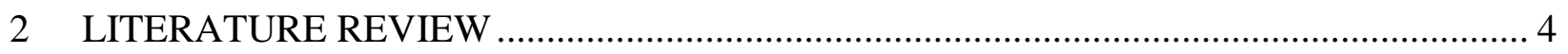

$2.1 \quad$ Champlain Sea Clay ................................................................................................... 4

2.1.1 Mineralogy of Champlain Sea sediments .............................................................. 4

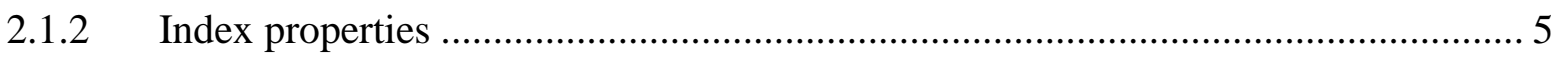

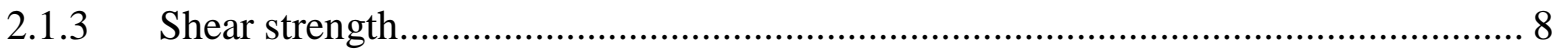

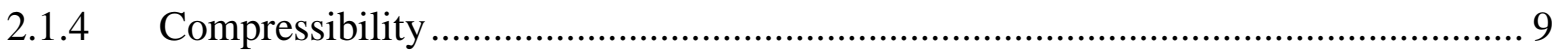

2.2 Leaching Impact on Soft Clays ……………….................................................. 10

2.2.1 Effect on soil index properties ........................................................................ 10

2.2.2 Effect on compressibility ......................................................................... 12

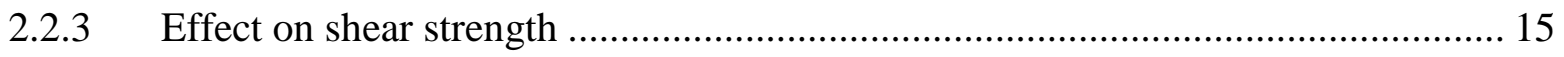

2.3 Deep Soil Mixing for Ground Improvement............................................................. 18

2.3.1 Mechanism of binder strength improvement ..................................................... 18

2.3.2 Factors affecting strength increase................................................................... 20

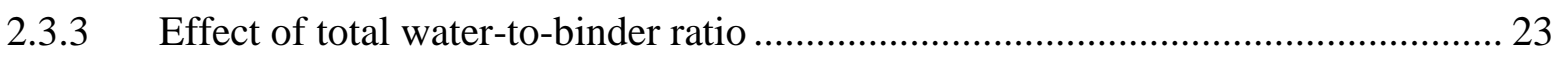

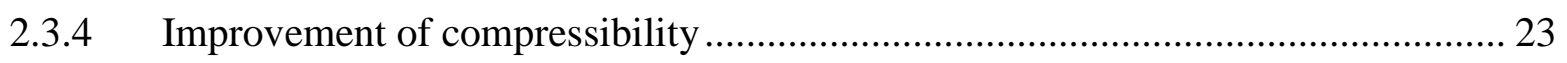




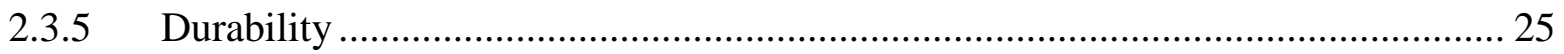

2.3.6 Applicability of DMM to soft clays..................................................................... 26

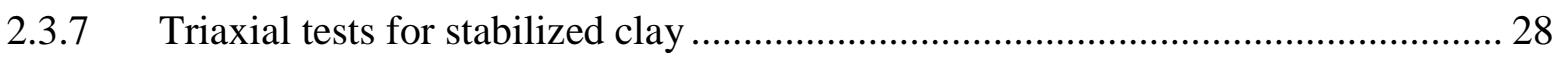

2.4 Leaching Impact on Cement-Treated Soft Clay ......................................................... 30

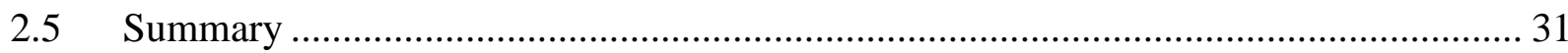

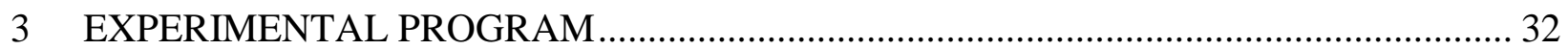

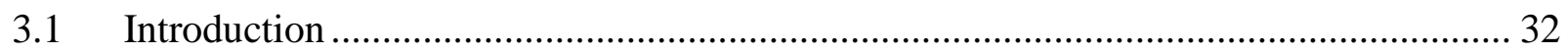

3.2 Index Properties of Undisturbed Champlain Sea Clay.................................................. 32

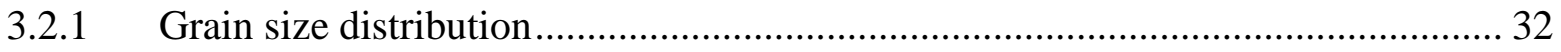

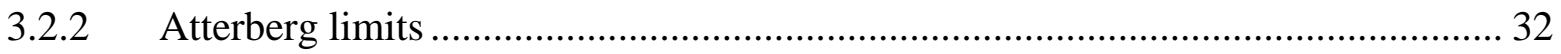

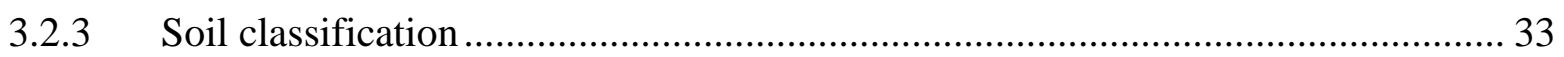

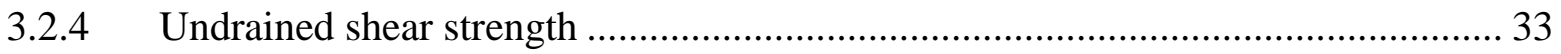

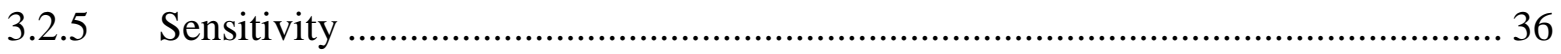

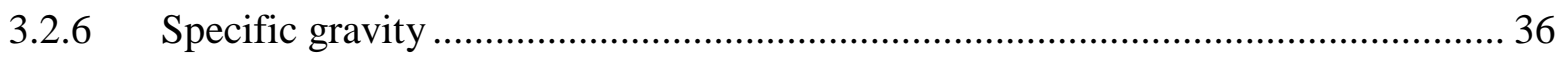

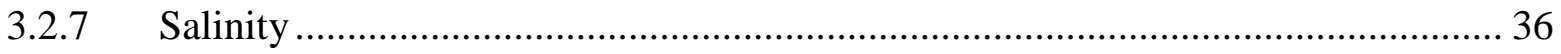

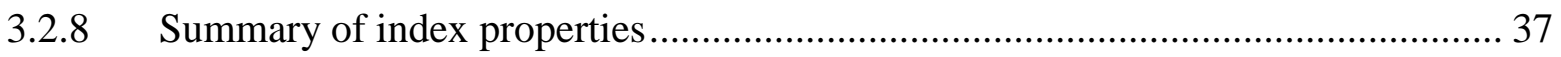

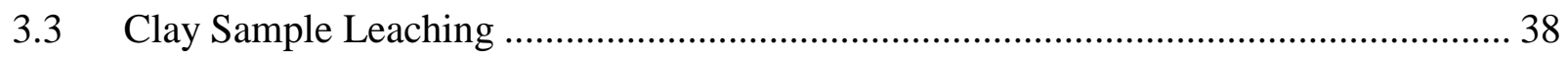

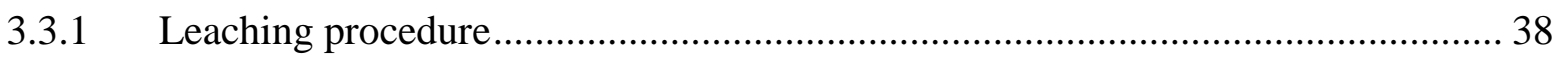

3.3.2 Index properties of leached soil ........................................................................ 42

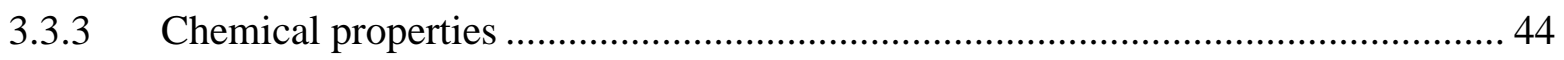

3.4 Shear Strength Properties Obtained from Test by Triaxial Testing ................................ 46

3.4.1 Sample Preparation for the triaxial testing......................................................... 47

3.4.2 Consolidated isotropic undrained test (CIU) ........................................................ 49

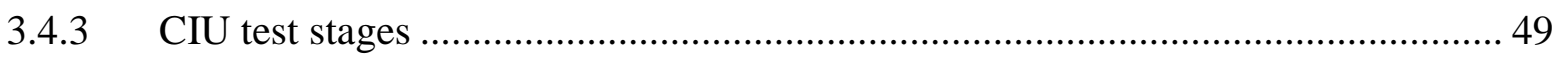

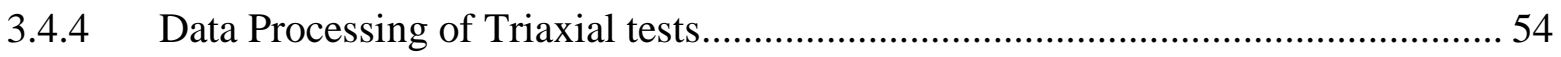

3.5 Compressibility Tests by CRS Testing Machine ………............................................... 56

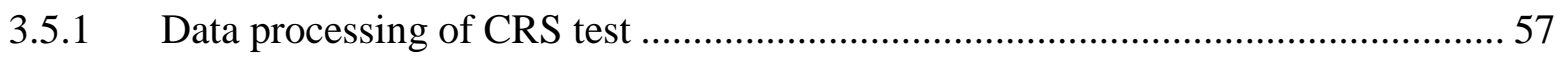

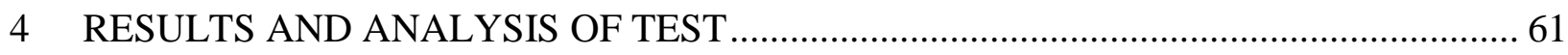

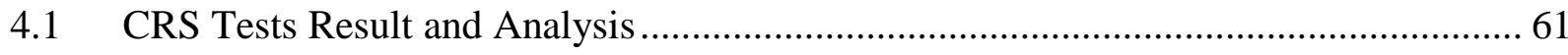


4.1.1 Leaching impact on the undisturbed Champlain Sea clay ............................... 61

4.1.2 Compressibility of cement treated Champlain Sea clay ..................................... 67

4.1.3 Compressibility of cement treated leached Champlain Sea clay ......................... 72

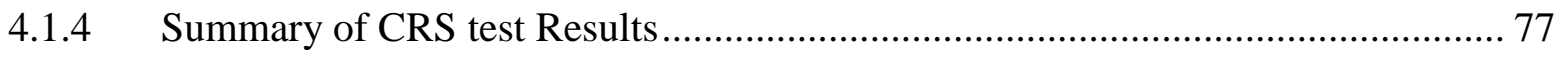

4.2 Shear Strength Tests Result and Analysis ........................................................... 83

4.2.1 Leaching impact on the undisturbed Champlain Sea clay …............................. 83

4.2.2 Shear strength of cement treated Champlain Sea clay ...................................... 89

4.2.3 Shear strength of leached cement treated Champlain Sea clay............................. 91

4.2.4 Summary of shear strength tests results .................................................... 93

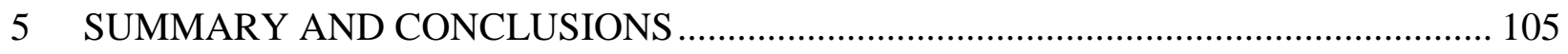

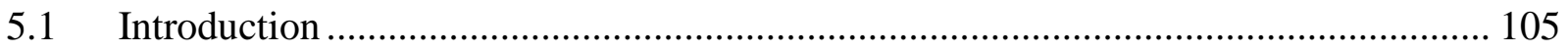

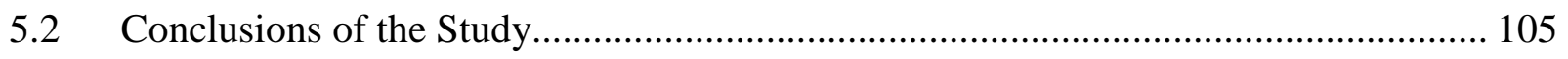

5.3 Recommendations for Future Study ............................................................. 106

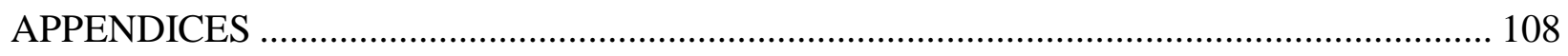

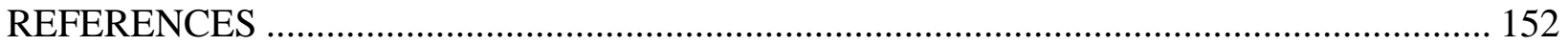




\section{LIST OF TABLES:}

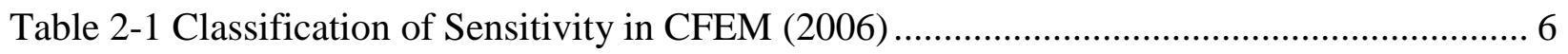

Table 2-2 Leaching effect on the soil Atterberg limits (Bjerrum, 954) .................................... 11

Table 2-3 Comparison of soil physical properties before and after leaching (Ismael, 1993) ....... 11

Table 2-4 Undrained shear strength parameters at different leaching level (Woo \& Moh, 1977) 17

Table 2-5 Factors affecting strength increase (Terashi, 1997) ............................................ 21

Table 3-1 Index properties of unleached Champlain Sea clay used in this study...................... 37

Table 3-2 Atterberg limits test results for leached and native soil samples in this study ............ 43

Table 3-3 Influence of back pressure and saturation time on B-value of native and DMM samples 51

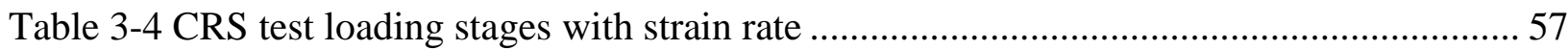

Table 4-1 Summary of consolidation parameters for native and leached samples.................... 64

Table 4-2 Summary of consolidation parameters for native and cement-treated native samples 70

Table 4-3 Summary of consolidation parameters for cement-treated leached and native samples

Table 4-4 Summary of consolidation parameters for all samples........................................ 1

Table 4-5 Shear strength parameters of the undisturbed native and leached samples................ 85

Table 4-6 Summary of mini vane shear strength results for native and leached samples .......... 87

Table 4-7 Shear strength parameters of the undisturbed unleached and leached soil samples..... 90

Table 4-8 Shear strength parameters for native, leached and cement mixed native soil samples 93

Table 4-9 Summary of CIU triaxial test results for all samples ......................................... 78 


\section{LIST OF FIGURES:}

Figure 2-1 Distribution of Champlain Sea clay (in gray color) in Canada (Quinn, 2013) ............ 4 Figure 2-2 Soil profile, Atterberg Limits, field moisture content of Champlain Sea clay near Lemieux, Ontario (Scott, 2003) .......................................................................................... 7

Figure 2-3 Undrained shear strength along the depths of Champlain Sea clays at Ottawa region obtained from laboratory tests, Field Vane test and SPT correlation (Nader, 2014).................... 8

Figure 2-4 Typical $e-\log p$ ' plot for soft sensitive clay (Nataraj, et al., 1990) ........................... 9

Figure 2-5 $e-\log p^{\prime}$ curves of 1-D traditional consolidation tests (Liu, et al., 2017) .................. 10

Figure 2-6 Grain size distribution of samples before and after leaching (Ismael, 1993)............ 12 Figure 2-7 Effect of leaching on soil sensitivity as measured from vane shear test (Woo \& Moh,

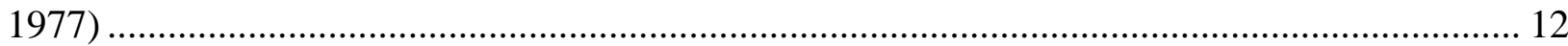

Figure 2-8 Void ratio against time for leached and unleached remoulded marine clay (Torrace,

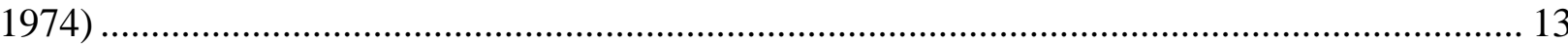

Figure 2-9 e log p plots for natural and leached samples (Ismael, 1993) ................................. 14

Figure 2-10 e log p curve for leached and unleached samples (Kim \& Do, 2009) .................... 15

Figure 2-11 Variation of compression index with salinity (right) and variation of swelling index

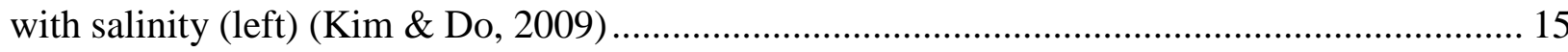

Figure 2-12 Stress-strain curves for leached and unleached marine clays (Torrace, 1974) ......... 16 Figure 2-13 Effective stress paths and envelopes of soils S35 (salinity level $35 \mathrm{~g} / \mathrm{L}$ ) and S7 (salinity level 7 g/L) (Woo \& Moh, 1977) ....................................................................... 17

Figure 2-14 Effective stress path and failure envelop for natural and leached specimen (Ismael, 1993) 18

Figure 2-15 Stages of cement stabilization (Kitazume \& Terashi, 2012)................................ 19

Figure 2-16 Mechanism of pozzolanic reaction (Ingles \& Metcalf, 1972).............................. 20

Figure 2-17 Relationship between cement content and unconfined compressive strength for cement treated soils (Mitchell, 1976) 22

Figure 2-18 Effect of curing time on unconfined compressive strength of cement treated soil (Mitchell, 1976) 22 
Figure 2-19 Unconfined compressive strength versus total water-to-cement ratio for laboratorymixed and tested specimens (Anon., 2013) 23 Figure 2-20 Consolidation curve for Bangkok clay with 25\% cement content (Bergado, et al.,

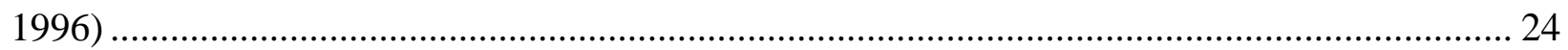

Figure 2-21 Influence of cement content on co-efficient of consolidation (Uddin, et al., 1997) . 25 Figure 2-22 Relationship between unconfined compressive strength and durability of cement treated soils based on Portland Cement Association durability criteria (ACI230.1R-90, 1990).. 26 Figure 2-23 Comparison on the compressibility of a native sample and a cement treated sample (Ahmad, 2018) 27

Figure 2-24 Stress- strain curve for the cement-treated Bangkok clay samples (Uddin, et al., 1997)

Figure 2-25 Undrained Stress-path for cement-treated Bangkok clay (Uddin, et al., 1997) ....... 29

Figure 2-26 e-log p curves of treated leached samples due to curing (Ahmad, 2018) ............... 31

Figure 2-27 e-log p curves of treated unleached samples due to curing (Ahmad, 2018) ............ 31

Figure 3-1 Grain size distribution of Chaplain sea clay at 22.20m depth................................ 33

Figure 3-2 Atterberg limit at different depth of Champlain Sea clay soil (Liu, et al., 2017) ....... 34

Figure 3-3 Soil classification at different depth of Champlain Sea clay soil sample (Liu, et al.,

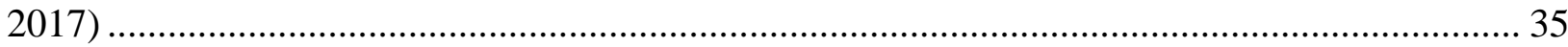

Figure 3-4 Undrained shear strength of Champlain Sea clay at different depth........................ 35

Figure 3-5 Sensitivity of Champlain Sea clay soil at different depths ................................... 37

Figure 3-6 Salinity of Champlain Sea clay at different depth .............................................. 38

Figure 3-7 Schematic diagram of the leaching test procedure ........................................... 39

Figure 3-8 Typical graph showing decrease in percentage of salinity level in the collected leachate

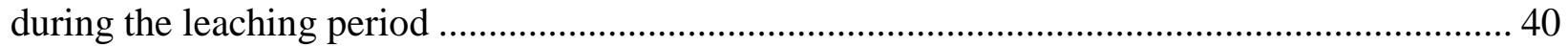

Figure 3-9 Typical cumulative mass of salt collection in leachate over time.......................... 41

Figure 3-10 Extruding the leached sample (right) and leached sample after being extruded (left)

Figure 3-11 Typical grain size distribution comparing leached and native samples .................. 42

Figure 3-12 Atterberg limits for native and leached soil samples ....................................... 44

Figure 3-13 Elemental composition as determined by the EDS for the unleached soil at $23.17 \mathrm{~m}$ depth (salinity level 9.75 g/L) 45 
Figure 3-14 Elemental composition as determined by the EDS for the leached soil at $23.17 \mathrm{~m}$ depth

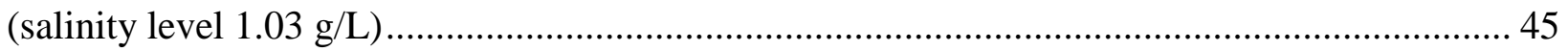

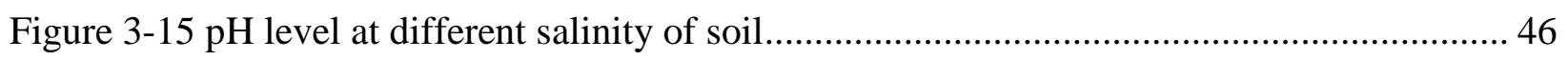

Figure 3-16 Native clay specimen before placing to a triaxial cell ............................................ 48

Figure 3-17 DMM sample preparation- a) DMM sample homogenous mixing, b) sample mold with filter paper, c) pouring DMM sample inside the mold, d) sample inside mold after being compacted, e) sealing the sample with the plastic wrap .......................................................... 48

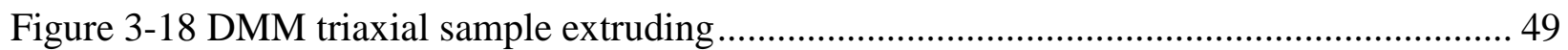

Figure 3-19 Sample saturation by increasing back pressure ............................................................ 50

Figure 3-20 Typical curve of increase in B-value with time .................................................... 51

Figure 3-21 Typical graph showing consolidation stage with time......................................... 52

Figure 3-22 Typical undisturbed soil specimen back and pore pressure response during shearing 53

Figure 3-23 Typical DMM specimen back and pore pressure response during shearing............ 54

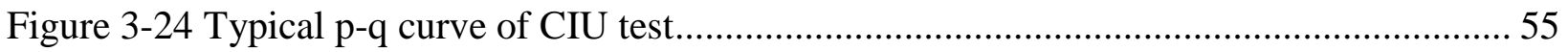

Figure 3-25 Typical stress-strain curve for sample of CIU test................................................... 56

Figure 3-26 Determination of pre-consolidation stress using the Pacheco Silva construction

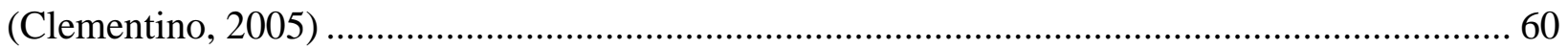

Figure 4-1 $\varepsilon-\log \sigma^{\prime}$ compression curve for untreated leached and unleached samples.................... 61

Figure 4-2 e-log $\sigma^{\prime}$ plot comparing untreated leached and unleached samples ............................. 62

Figure 4-3 Influence of leaching on e-log p curve of undisturbed Sample at 38m depth of Champlain Sea clay (Ahmad, 2018). 63

Figure 4-4 Variation of Mv versus log effective stress of untreated leached and unleached samples 65

Figure 4-5 Hydraulic conductivity of untreated leached and unleached samples 66 Figure 4-6 Variation of $\mathrm{Cv}$ versus log effective stress of untreated leached and unleached samples 66

Figure 4-7 $\varepsilon-\log \sigma^{\prime}$ compression curves for undisturbed unleached and unleached treated samples 68

Figure 4-8 e-log $\sigma^{\prime}$ curves of undisturbed unleached and unleached treated samples 68 
Figure 4-9 Variation of Mv versus effective stress of undisturbed unleached and unleached treated

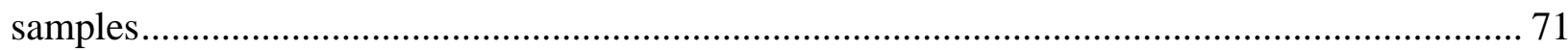

Figure 4-10 Hydraulic conductivity of undisturbed unleached and unleached treated samples... 71

Figure 4-11 Cv-log $p$ curves of undisturbed unleached and unleached treated samples ............. 72

Figure 4-12 $\varepsilon-\log \sigma^{\prime} p$ compression curve for cement-mixed native and leached samples ........... 73

Figure 4-13 e-log $p p^{\prime}$ curves of cement-treated Champlain Sea clay samples ......................... 74

Figure 4-14 Mv-log $p$ curves of cement-treated leached and unleached samples .................... 76

Figure 4-15 Hydraulic conductivity of cement-treated leached and unleached samples............. 76

Figure 4-16 Cv-log $p$ of cement-treated leached and unleached samples ................................. 77

Figure 4-17 Typical e-log p' plot for different clay samples ............................................... 78

Figure 4-18 Impact of salinity on pre-consolidation pressure $\left(p^{\prime} c\right)$ for different samples .......... 79

Figure 4-19 Impact of salinity on vertical strain $(\varepsilon)$ for different samples .............................. 79

Figure 4-20 Impact of salinity on compression index (cc) for different samples ...................... 80

Figure 4-21 Impact of salinity on recompression index (cr) for different samples ................... 80

Figure 4-22 Typical deviator stress vs axial strain from CIU triaxial tests for undisturbed unleached

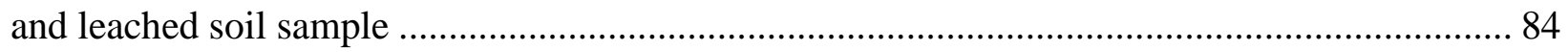

Figure 4-23 Comparison of normalized deviator stress-strain for undisturbed unleached and

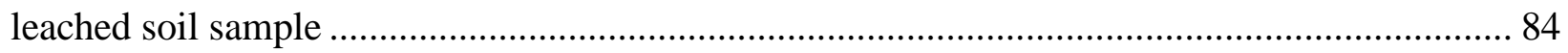

Figure 4-24 Effective stress paths and envelops of unleached and leached soil sample ............. 86

Figure 4-25 Undrained shear strength of soil sample at different leaching level ...................... 88

Figure 4-26 Sensitivity of soil at different leaching levels compared to the native soil............. 88

Figure 4-27 Comparison of normalized deviator stress-strain for undisturbed unleached and

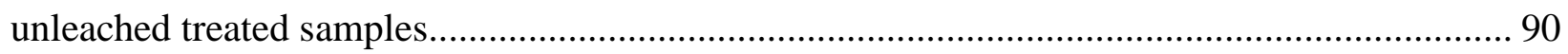

Figure 4-28 Effective stress paths and envelops of undisturbed unleached and unleached treated

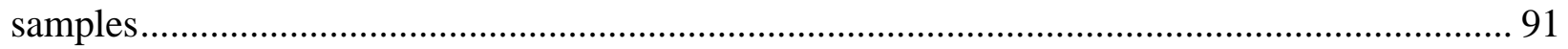

Figure 4-29 Effective stress paths and envelops of unleached treated and leached treated samples 92 


\section{LIST OF APPENDICES:}

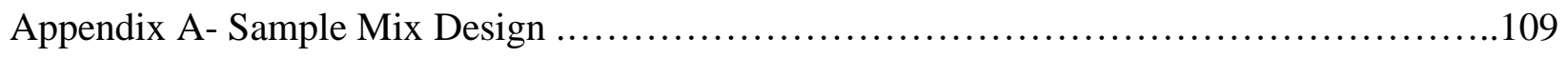

Appendix B - Leaching process ............................................... 112

Appendix C- Triaxial Test Results ...............................................116

Appendix D- CRS Test Results ................................................ 129 


\section{INTRODUCTION}

\subsection{Background}

Champlain Sea clay or Leda clay is the late Glacial marine clay, found throughout the Ottawa-St. Lawrence lowlands. This type of clay was deposited in a marine estuarine type environment where sediments were comprised mostly of clay-sized particles $(\leq 2 \mu)$. The clay is susceptible to land slides which constitutes one of the principal terrain of hazards affecting property and human life in the eastern Canada. This type of clay is also known for its low shear strength, high compressibility and highly sensitive characteristics.

Since Champlain Sea clay was deposited under the marine environment, a high initial pore water salt concentration is expected. As the soil is exposed above the sea-level, the salt concentration in the pore water can be reduced by leaching with fresh water, flood, and the soil may eventually transformed into quick clay. Many researchers have investigated the leaching effects on the geotechnical properties of soft clays through leaching and consolidation tests. A decrease in the

salinity of the clay can cause an increase in its compressibility and lower its shear strength and liquid limit which has been reported by many researchers (Torrace, 1974; Woo \& Moh, 1977; Ismael, 1993; Kim \& Do, 2009).

Due to the high compressibility and low shear strength of Champlain Sea clay, it is essential to improve the soil properties for any infrastructure development in that area. Different ground improvement techniques are available today. Deep mixing method (DMM) is one kind of ground improvement technique that introduces a cementitious binder mixed to the problematic soil to improve its strength and compressibility properties. DMM technique was first used in Japan in early 1970s (Kitazume \& Terashi, 2012). The unique advantages of DMM over other ground improvement methods include a quick strength increase, high cost efficiency, minimum environmental disturbance, and wide range of soil applicability (Bruce, 2000). Due to DMM's ability to treat difficult soils, it soon became a popular technique with many applications in the United States, western Canada, and the rest of the world. DMM is rarely used in eastern Canada. Terashi et al. (1997) has demonstrated that pore water of soil can affect the strength improvement. However, investigation of the effect of pore fluid salinity level on the strength and compressibility behaviour on the cement mixed sensitive clay is scarce. Therefore, geotechnical investigation in this area became necessary. 


\subsection{Research Objectives}

As formed under high salinity condition, Champlain Sea clay is susceptible to leaching by the fresh water, percolation of rainwater, and hydraulic pressure at the base of the soil layer. Studies conducted by the researchers on soft marine clays demonstrated that leaching has an impact on the geotechnical properties of soil. On the other hand, Deep mixing method (DMM) that is intended to improve the soil strength and compressibility properties of soft clay, may also susceptible to leaching. Leaching impact on stabilized Champlain Sea clay has rarely investigated by the researchers. The main objectives of this research are to investigate the leaching impact on the shear strength and compressibility behaviour on the undisturbed and cement-treated Champlain Sea clay soil. First, the soil sample will be leached by using leaching test apparatus at Ryerson geotechnical laboratory. Next, a series of laboratory tests will be conducted including index properties, vane shear tests, triaxial tests and constant rate of strain (CRS) tests on undisturbed and cement-treated samples at different salinity levels.

\subsection{Research Methodology}

In order to achieve the research objectives, a series of mechanical test will be performed which are shown below:

$>$ Evaluate the shear strength and compressibility properties of native clay samples through a series of laboratory tests;

$>$ Conduct leaching tests on native soil samples and continue the leaching process until desired salinity level has been achieved;

$>$ Determine the shear strength and compressibility of leached clay soil properties at different leaching levels through a series of laboratory tests;

$>$ Determine the shear strength and compressibility properties of cement mixed clay samples through a series of laboratory tests. General use Portland cement will be used to treat the sample at a dosage of $50 \mathrm{~kg} / \mathrm{m}^{3}$ per total volume of the mix and samples will be cured for 7 days;

Determine the shear strength and compressibility properties of cement-treated leached clay samples at different pore fluid salinity levels through a series of laboratory tests;

> Finally, analyze and evaluate the leaching impact on shear strength and compressibility properties of the native and cement-treated soil. 


\subsection{Thesis Organization}

This thesis is organized in five chapters, including this chapter.

Chapter 1 provides the background information, objectives, and study methodology of research. Chapter 2 presents literature review of the behaviour and parameters of sensitive Champlain Sea clay clays in Ottawa including shear strength, compressibility, sensitivity, salinity, $\mathrm{pH}$, and Atterberg limits. This chapter also contains previous studies that were conducted on the leaching phenomenon and its impact on the shear strength and compressibility of soil. And, DMM as a ground improvement technique and its impact on the strength and compressibility of soil is also discussed in this chapter.

Chapter 3 explains the experimental lab program, parameters obtained from experiments, experimental devices developed for this study, and the testing machine used. The sample preparation procedure, testing method and procedures, data processing and calculations are also presented in this chapter.

Chapter 4 discusses all the test results obtained from CRS and triaxial test results and analyzes the impact of leaching on the compressibility of undisturbed and cement-treated samples.

Chapter 5 presents summary and conclusion of this thesis. 


\section{LITERATURE REVIEW}

The literature review covered unleached and leached Champlain Sea clay soil index, strength and compressibility properties. The shear strength and compressibility properties of cement stabilized Champlain Sea clay before and after leaching is also covered.

\subsection{Champlain Sea Clay}

Champlain Sea clay or Leda clay is one of the sensitive and fine-grained late glacial marine clays commonly found along the St. Lawrence Lowlands region in Ontario and Quebec (Duhaime, et al., 2013). Figure 2-1 illustrates the distribution of Champlain Sea clay near Ottawa, Montreal, and other high population areas along the St. Lawrence River. Champlain Sea clay is also known for its susceptibilities to landslides that mostly occurred along the valley slopes of rivers.

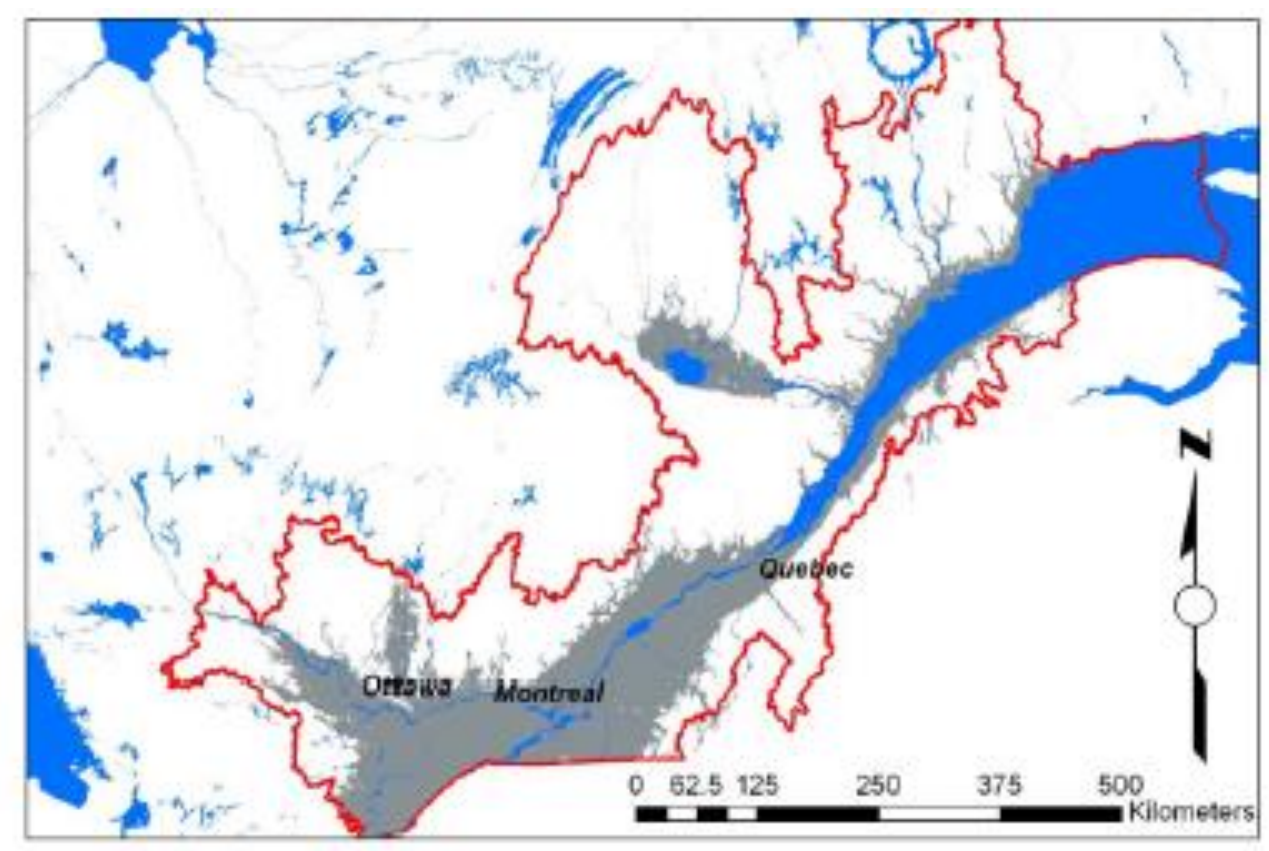

Figure 2-1 Distribution of Champlain Sea clay (in gray color) in Canada (Quinn, 2013)

\subsubsection{Mineralogy of Champlain Sea sediments}

Clay sized $(<2 \mu \mathrm{m})$ material of late glacial marine clays mostly ranges from 43 to 93 percent with an average of 83 percent (Quigley, et al., 1985). Approximately 50 percent of the clay fraction consists of quartz, feldspars, carbonate and amphiboles, and remainders are illite, vermiculite and chlorite with minor amount of swelling clay minerals (Scott, 2003). 


\subsubsection{Index properties}

Water content and its relation to the liquid limit and liquidity index value can be important indicators of geotechnical behavior of Champlain Sea clay. Liquidity index is measured by the relationship $\mathrm{I}_{\mathrm{L}}=\left(\mathrm{W}_{\mathrm{N}}-\mathrm{W}_{\mathrm{P}}\right) /\left(\mathrm{W}_{\mathrm{L}}-\mathrm{W}_{\mathrm{P}}\right)$ where $\mathrm{W}_{\mathrm{N}}, \mathrm{W}_{\mathrm{P}}$ and $\mathrm{W}_{\mathrm{L}}$ are the natural water content, plastic limit, and liquid limit, respectively. Taha (2010) collected samples from depths around 8 to 12 meters at the Tenth Line Road in Ottawa and reported an $\mathrm{I}_{\mathrm{L}}$ value of 1.4. Quigley et al. (1985) mentioned that the average $I_{L}$ value is close to unity, and the $I_{L}$ value increases with depth for the upper clays (in usual situation) whereas in the lower clays generally decreases with depth. A similar pattern of $I_{L}$ values was also reported by Scott (2003) as shown in Figure 2-2. Liquidity index more than unity might be one of the contributing factors for Chaplain clays to become highly sensitive as mentioned by Eden and Crawford (1965).

Scott (2003) mentioned that soils with moisture content above their liquid limits would be transformed from solid or plastic state to fluid when remolded. An induced stress or remolding of the clay may lead to de-structuration of natural soil fabric that contributes to the change in state of sensitive clay from solid to fluid. High water contents and weak bonds between soil particles could possibly be the reason of this change in state (Quigley, et al., 1985). The ratio of the undrained shear strength of undisturbed soil sample to that of remoulded one at the same water content is called soil sensitivity. Table 2-1 shows the soil sensitivity classification according to the Canadian foundation engineering manual (CGS, 2007). Champlain clay near Lemieux (Ontario) area was found to be highly sensitive since sensitivity value was greater than 4 in most soil layers (Scott, 2003), as shown in Figure 2-2. Other researchers also mentioned about the highly sensitivity of Champlain sea clay (Eden \& Crawford, 1957; Quigley, et al., 1985; Nader, 2014). Quigley (1980) stated that the factors producing low remolded strength and high sensitivity are as follows:

i. High in-situ water content $\left(\mathrm{W}_{\mathrm{N}}>\mathrm{W}_{\mathrm{L}}\right)$

ii. Low specific surface of soil grains

- High silt content or high rock flour in $<2 \mu$ m fraction

- High primary mineral = low clay mineral content

iii. High Zeta Potential

- Expanded double layers = high inter-particle repulsion

- High Inter-particle repulsion $=$ dispersed or peptized state 
- Low salinity by leaching $(<2 \mathrm{~g} / \mathrm{L})$

- Organic and inorganic dispersants (anion adsorption)

- High monovalent cation adsorption relative to divalent cations

iv. Low amorphous content

v. Low smectite content

Table 2-1 Classification of Sensitivity in CFEM (2006)

\begin{tabular}{|l|l|}
\hline Sensitivity & Clay Sensitivity \\
\hline $\mathrm{S}_{\mathrm{t}}<2$ & Low sensitivity \\
\hline $2<\mathrm{S}_{\mathrm{t}}<4$ & Medium sensitivity \\
\hline $4<\mathrm{S}_{\mathrm{t}}<8$ & Sensitive \\
\hline $8<\mathrm{S}_{\mathrm{t}}<16$ & Extra-sensitive \\
\hline $\mathrm{S}_{\mathrm{t}}>16$ & Quick Clay \\
\hline
\end{tabular}

The pore fluid salinity also plays a very important role in shear strength of soil. The values of total salinity expressed in grams/litre, $\mathrm{NaCl}$ equivalent, usually obtained by conductivity measurements. Haynes (1975) tested four boreholes in Hawkesbury, Ontario to study their geochemical and mineralogical profiles. In the report it was mentioned that sensitivity is inversely proportional with its salinity, which is supported by findings from other researchers (Quigley, et al., 1985). Torrance (1975) mentioned that the remolded shear strength increased significantly when pore salinity values increases from $0.34 \mathrm{~g} / \mathrm{L}$ to $3 \mathrm{~g} / \mathrm{L}$, while the increase in shear strength is less significant when salinity increases from $3 \mathrm{~g} / \mathrm{L}$ to $20 \mathrm{~g} / \mathrm{L}$ (Torrace, 1975). This research also mentioned that the interaction between clay particles is influenced by porewater salt concentration and the high porewater salinity contributes to maintain a high remoulded shear strength, which was consistent in all the boreholes he tested. 


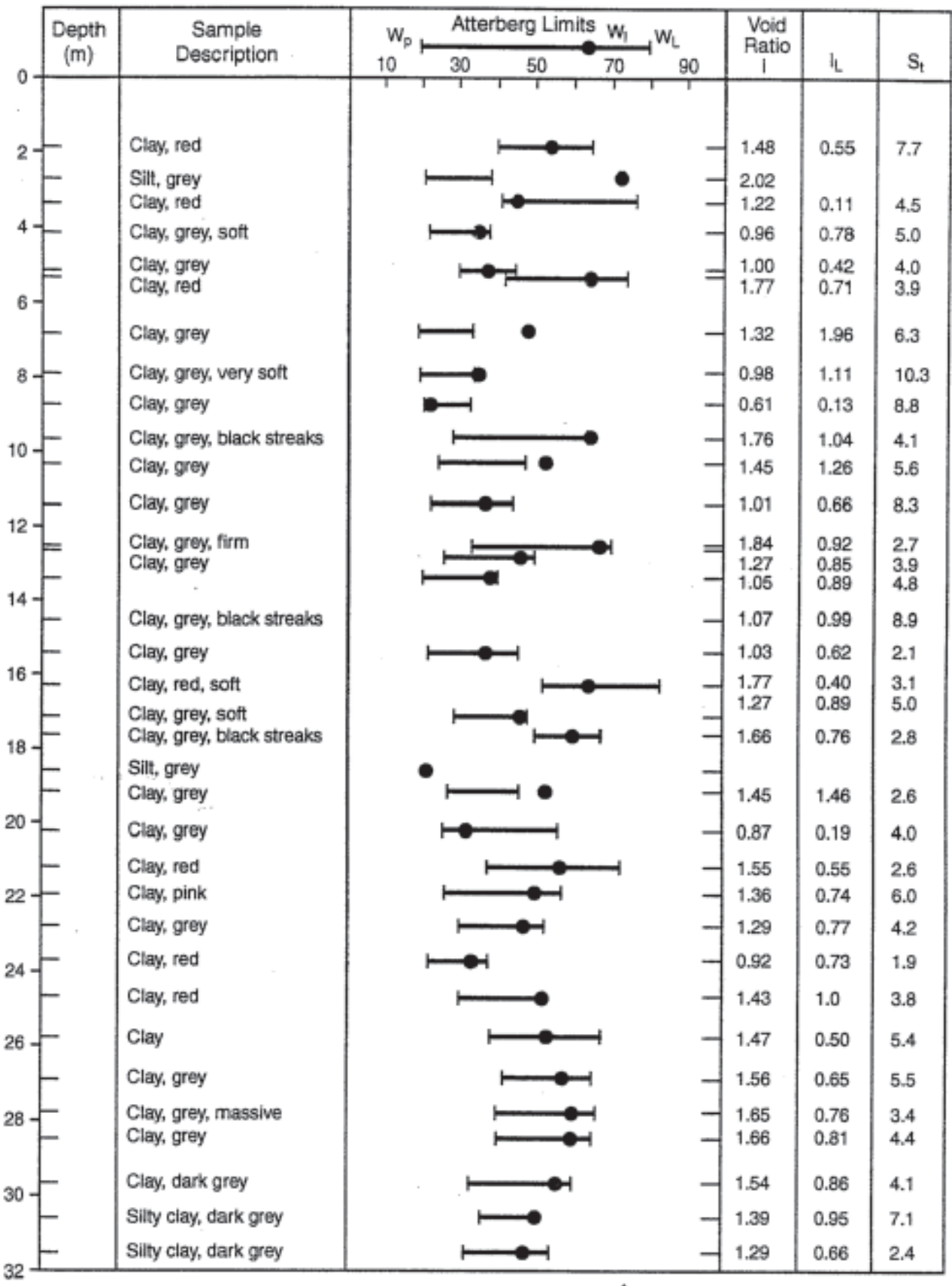

Figure 2-2 Soil profile, Atterberg Limits, field moisture content of Champlain Sea clay near Lemieux, Ontario (Scott, 2003) 


\subsubsection{Shear strength}

In any geotechnical design the undrained shear strength of soft clays is an important parameter, particularly for the design of foundations and embankments on soft clay. Some common methods to estimate the undrained shear strength of clay - correlations with cone penetration data, correlations with standard penetration test (SPT) data, direct measurement with field or laboratory vane shear test (VST) and unconfined compressive strength (UCS) test. Since in many cases it is too hard to form a disturbed UCS specimen, vane shear test is often used to replace the UCS for measuring the sensitivity of soft soil in field and laboratory.

The distribution of undrained shear strength of Champlain Sea clay over depth is reported by many researchers. Yafrate and Dejong (2006) mentioned that in Gloucester, Ontario the values of undrained shear strength of Champlain Sea clays at 4.5 and $8.5 \mathrm{~m}$ is 20 and $34 \mathrm{kPa}$ respectively.

Nader (2014) summarized different tests conducted along the depth of Champlain Sea clays at the Ottawa region. He mentioned that the field vane tests (FVTs) may give higher values than that of the laboratory results. He found that from $5 \mathrm{~m}$ to $25 \mathrm{~m}$ the undrained shear strength varying from 20 to $35 \mathrm{kPa}$ whereas the values from 50 to $75 \mathrm{kPa}$ was obtained by using FVTs.

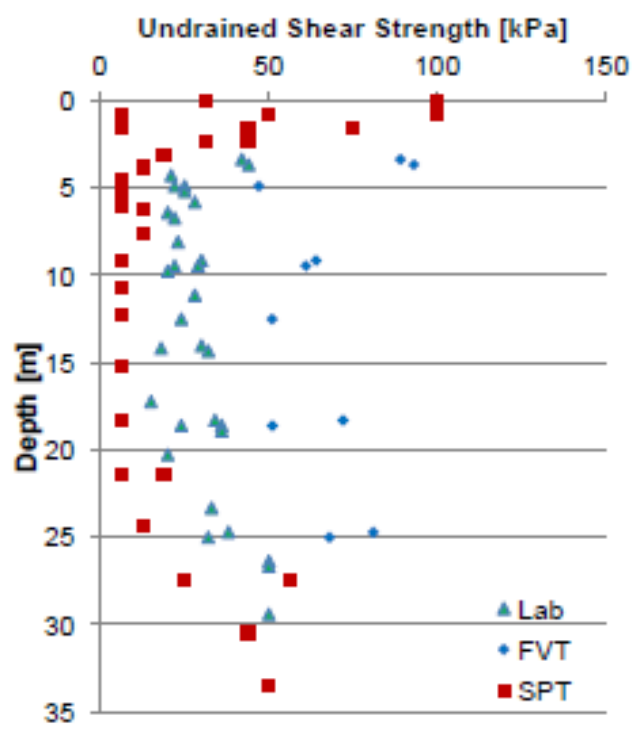

Figure 2-3 Undrained shear strength along the depths of Champlain Sea clays at Ottawa region obtained from laboratory tests, Field Vane test and SPT correlation (Nader, 2014) 


\subsubsection{Compressibility}

Settlement issues have posed a special problem that restricts the development in the coastal regions due to the highly compressible marine clays. Void ratio versus effective consolidation pressure ( $e$ $\left.\log p^{\prime}\right)$ relationship provides important information in solving the settlement issues. This can be obtained by performing either 1-D oedometer test or constant rate of strain (CRS) test on undisturbed soil samples.

Nataraj, et al. (1990) briefly explained $e$ - $\log p^{\prime}$ curve for the undisturbed and remolded soft sensitive clay, as shown in Figure 2-4. He mentioned that usually up to $1 \%$ of strain, compression is negligible. As the strain passes by $1 \%$, a steep slope is observed in the virgin compression line which indicates sudden compression of the specimen and formed an inverse S-shaped curve. He divided the curve into 3 zones: zone 1 as the zone where the response is nearly rigid; zone 2 as gradual breakdown of soil bonds; and zone 3 as completely breakdown of bonds behaving as remolded soil.

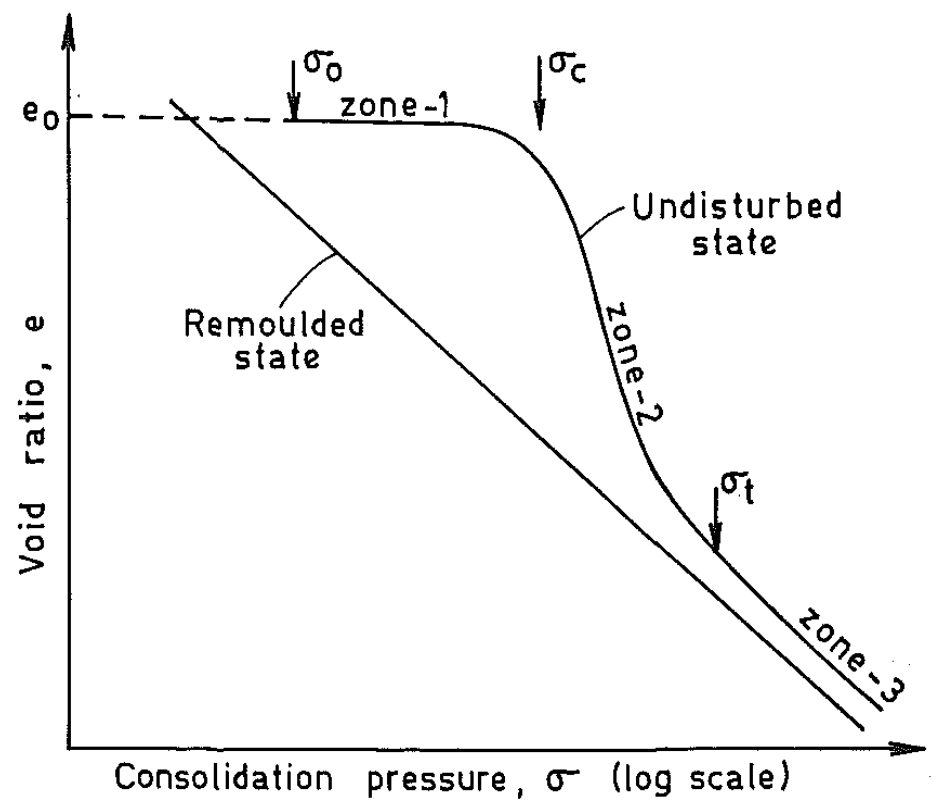

Figure 2-4 Typical $e-\log p$ ' plot for soft sensitive clay (Nataraj, et al., 1990)

Liu et al. (2017) also conducted 1-D Oedometer test on the Champlain Sea clay sample. It was mentioned that the clay sample is highly compressible as shown briefly in Figure 2-5. 


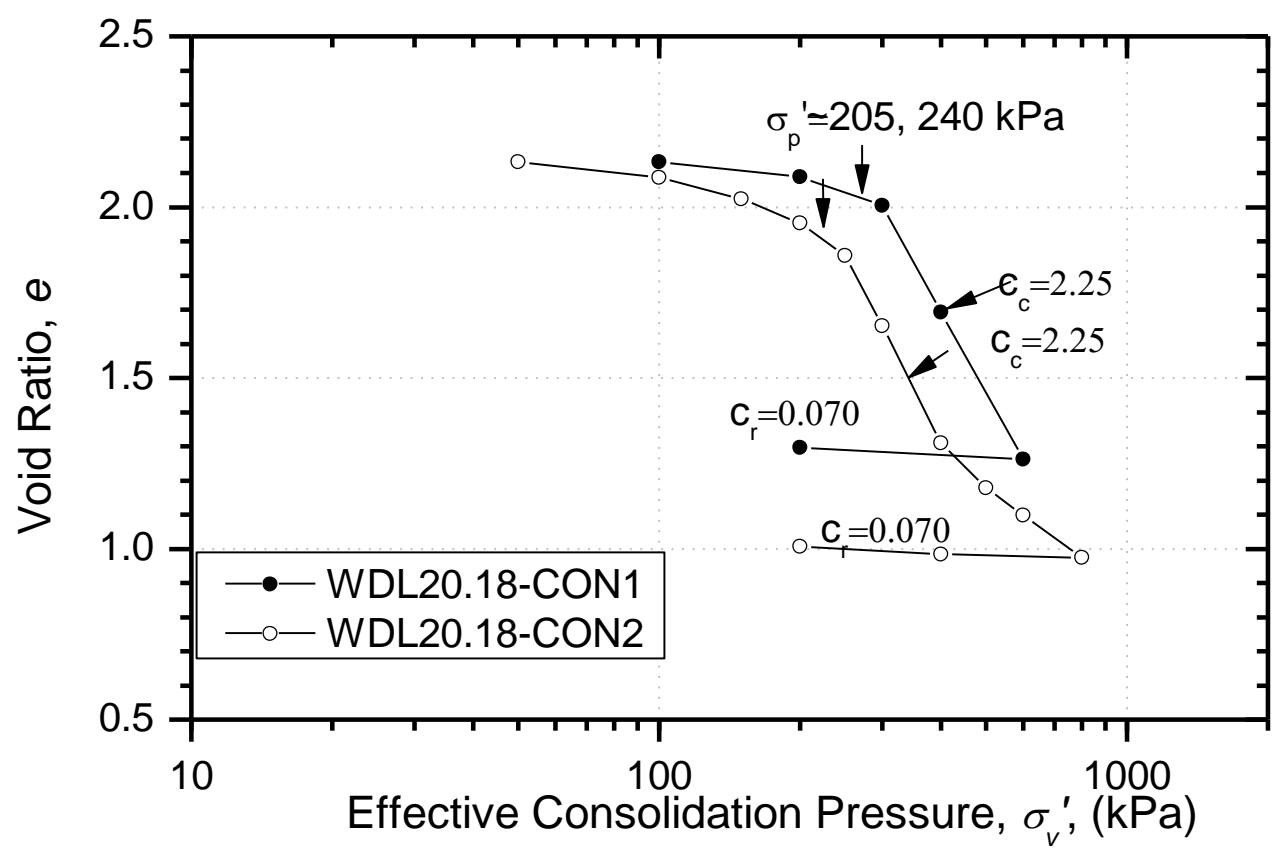

Figure 2-5 $e-\log p^{\prime}$ curves of 1-D traditional consolidation tests (Liu, et al., 2017)

\subsection{Leaching Impact on Soft Clays}

Due to seepage of rain water, flood water through soil, and fresh water of sea could leach salt away from the marine clay deposit. La Rochelle et al. (1970) stated that a valley like substructure underlying the clay deposits created a downward percolation and an upward flow gradient by leached actively the salt content of the clay. Salt leaching upsets the balances of the interparticle electrical forces and particles alignment, which in turn causes the instability of the soil structure. Champlain Sea clay was formed under high salinity water conditions with high electrolyte. One phenomenon which increased the sensitivity of Champlain Sea clay is salt leaching. Penner \& Burn (1977) mentioned that leaching reduces the electrolyte concentration at points of contact, causing water release from the pores of the soil fabric destroying soil's bond and structure integrity.

\subsubsection{Effect on soil index properties}

Bjerrum (1954) investigated the leaching effect on Norwegian marine clay. He found a decrease in liquid limit when the soil was leached, as shown in Table 2-2. 
Table 2-2 Leaching effect on the soil Atterberg limits (Bjerrum, 954)

\begin{tabular}{|l|c|c|c|}
\hline Parameters & Remarks & Natural clay & Leached clay \\
\hline Water content (\%) & Unaltered & 40.4 & 41.0 \\
\hline Liquid limit (\%) & Decreased & 43.4 & 27.4 \\
\hline
\end{tabular}

A series of laboratory and field testing on native and leached marine clay soil samples were conducted by Ismael (1993). The project site is located near the Persian Gulf coast in Doha, Kuwait. The tests data reveal that the bulk density, specific gravity, Atterberg limits, unconfined compressive strength, clay contents, and conductivity was decreased when the samples were leached, as shown in table 2-3. In his study, he also observed that the percentage of fines was substantially increased due to breaking of sand-size particles into smaller sizes of silt, as shown in Figure 2-6.

Table 2-3 Comparison of soil physical properties before and after leaching (Ismael, 1993)

\begin{tabular}{|l|c|c|c|c|c|c|c|c|c|}
\hline $\begin{array}{l}\text { Sample } \\
\text { type }\end{array}$ & $\begin{array}{c}\text { Total } \\
\text { dissolve } \\
\text { salts } \\
\text { (TDS) }\end{array}$ & $\begin{array}{c}\text { Unit } \\
\text { weight } \\
\left(\mathrm{Mg} / \mathrm{m}^{3}\right)\end{array}$ & $\begin{array}{c}\text { Moisture } \\
\text { Content } \\
(\%)\end{array}$ & $\begin{array}{c}\text { Specific } \\
\text { gravity }\end{array}$ & $\begin{array}{c}\text { Liquid } \\
\text { limit }\end{array}$ & $\begin{array}{c}\text { Plastic } \\
\text { limit }\end{array}$ & $\begin{array}{c}\text { Passing } \\
\text { no. } 40 \\
\text { sieve } \\
(\%)\end{array}$ & $\begin{array}{c}\text { Passing } \\
\text { no. 200 } \\
\text { sieve } \\
(\%)\end{array}$ & $\begin{array}{c}<0.002 \\
\mathrm{~mm}\end{array}$ \\
\hline Natural & 30,000 & 1.69 & 17.7 & 2.28 & 35 & 33 & 84 & 60.4 & 4.2 \\
\hline Leached & 2,200 & 1.57 & 17.0 & 2.22 & 23 & N.P. & 99.35 & 97.4 & 3 \\
\hline
\end{tabular}

A series of laboratory vane shear test was conducted by Woo \& Moh (1977) where the impact of salinity on the soil sensitivity was analysed on Bangkok clay. Sensitivity was analysed by slowly reducing the salt concentration from $35 \mathrm{~g} / \mathrm{L}$ to $5 \mathrm{~g} / \mathrm{L}$. Test results showed that soil sample sensitivity increased as the salt concentration was decreased as shown in Figure 2-7.

Kim (2008) also investigated the leaching effect on the Atterberg limits in Busan clay and found that liquid limit decreased when the sample leached. 


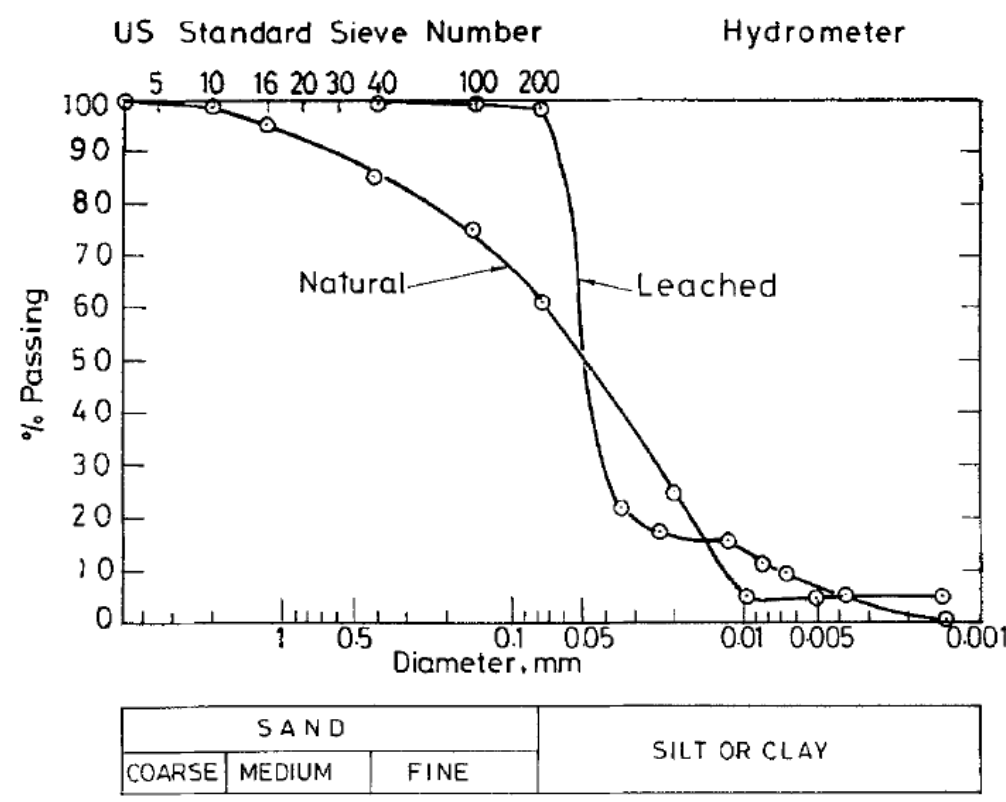

Figure 2-6 Grain size distribution of samples before and after leaching (Ismael, 1993)

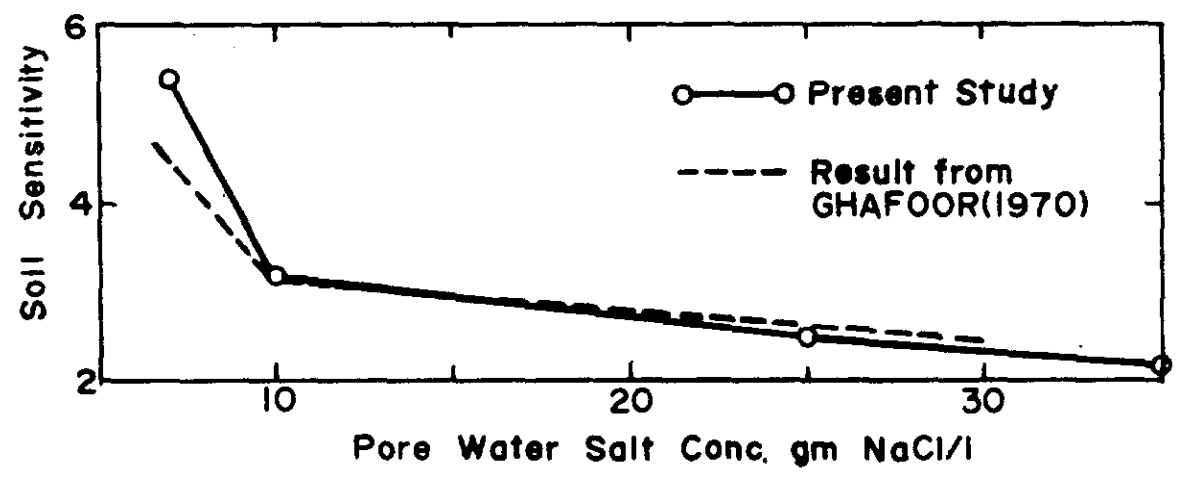

Figure 2-7 Effect of leaching on soil sensitivity as measured from vane shear test (Woo \& Moh, 1977)

\subsubsection{Effect on compressibility}

Torrace (1974) conducted leaching experiments with undisturbed and remoulded samples of Norwegian marine clay. He mentioned that the major changes in liquid and plastic limits, remoulded shear strength and sensitivity occurred when salinity was reduced to be below $2 \mathrm{~g} / \mathrm{L}$. He observed that when sample was leached, liquid limit and undrained shear strength were 
decreased, whereas sensitivity was increased. The experimental results showed that a spontaneous settlement was occurred as pre-consolidation pressure reduced when the salt was leached from undisturbed marine clay sample as shown in Figure 2-8.

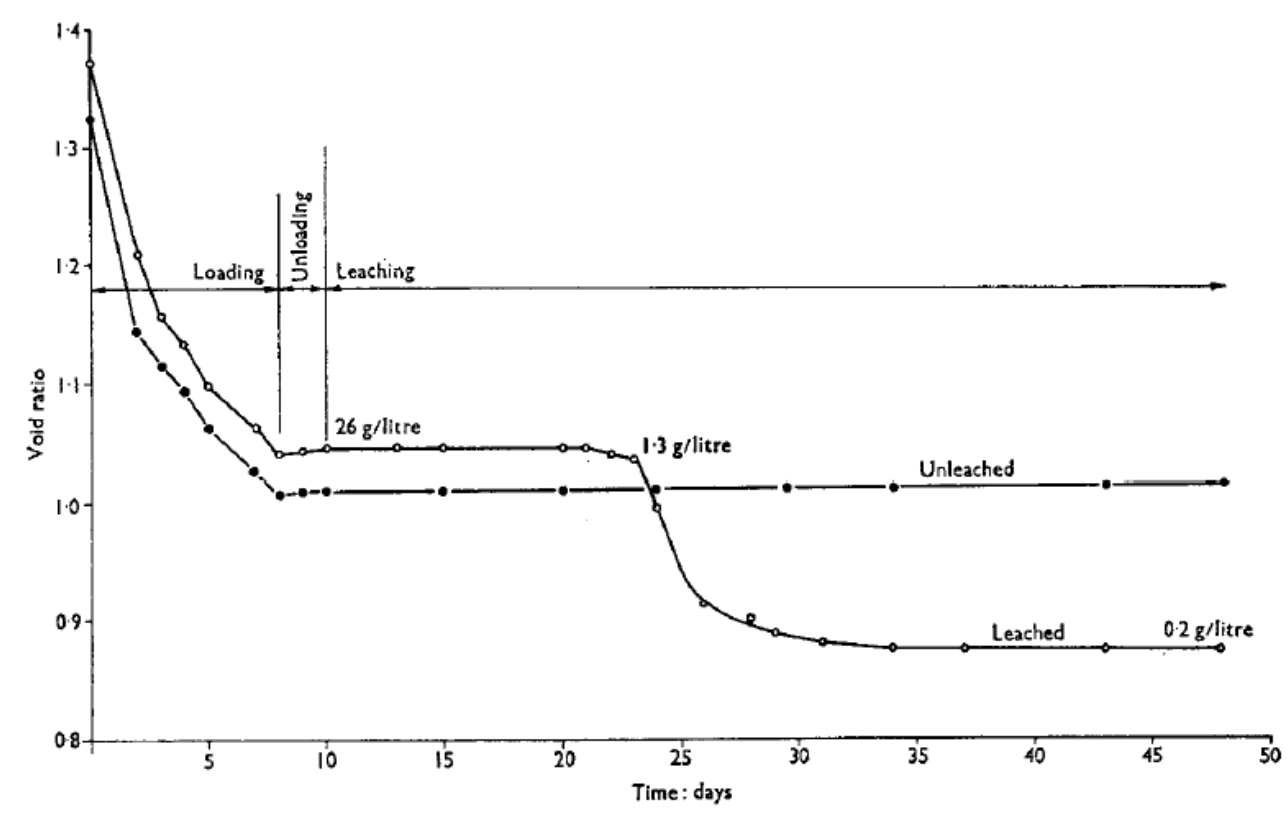

Figure 2-8 Void ratio against time for leached and unleached remoulded marine clay (Torrace, 1974)

Ismael (1993) analysed the compressibility of leached and natural marine clay sample using a Rowe apparatus. From his tests, an increase in the compressibility was evident when the sample was leached. The compressibility was increased by $30 \%$ when total dissolve salt level decreased from 30,000 to 2,200 unit when native sample leaches, as shown in Figure 2-9. 


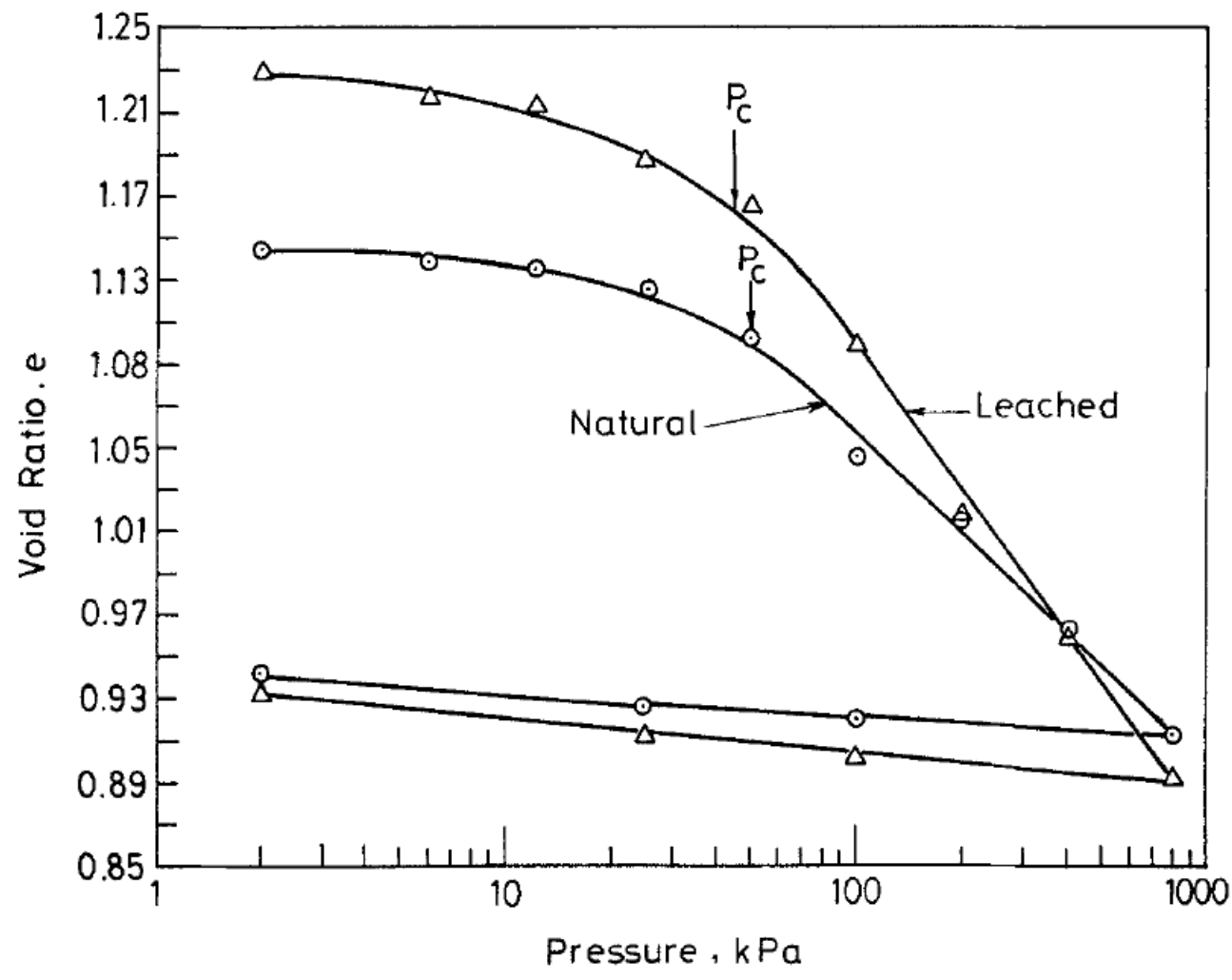

Figure 2-9 e $\log$ p plots for natural and leached samples (Ismael, 1993)

Kim \& Do (2009) did a series of CRS tests on Busan clay to evaluate the effect on compressibility on leached sample comparing with the uneached one. When the sample was leached, it becomes more compressible as mentioned by Torrace (1974) and Ismael (1993). Figure 2-10 shows briefly that when the salinity in the sample was leached from $16 \mathrm{~g} / \mathrm{L}$ to $3 \mathrm{~g} / \mathrm{L}$, the sample becomes more compressible with a reduction in the pre-consolidation pressure. Figure 2-11 also shows that the compressibility index and swelling index increased as the salinity level decreased. 


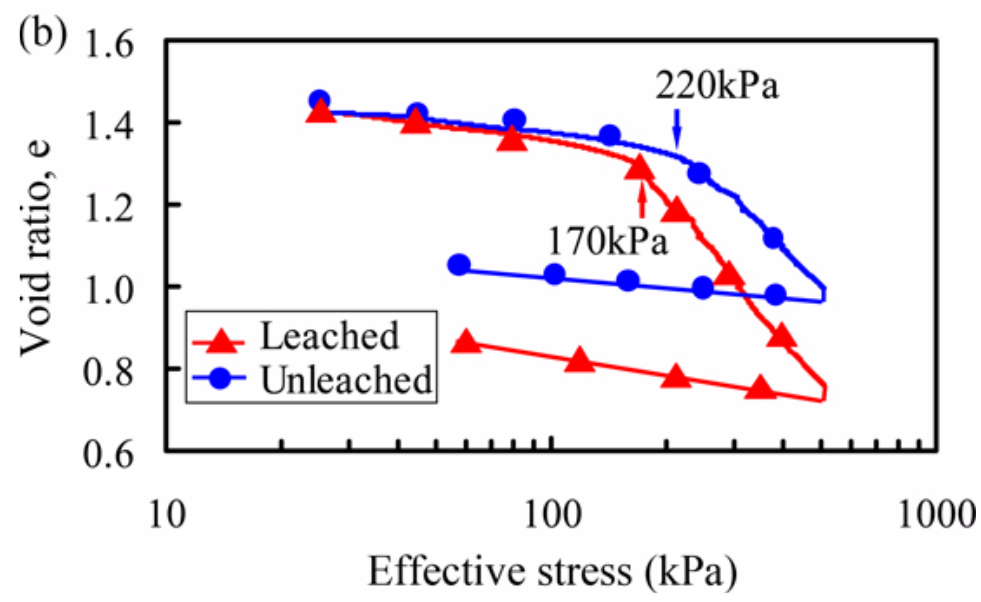

Figure 2-10 e log p curve for leached and unleached samples (Kim \& Do, 2009)
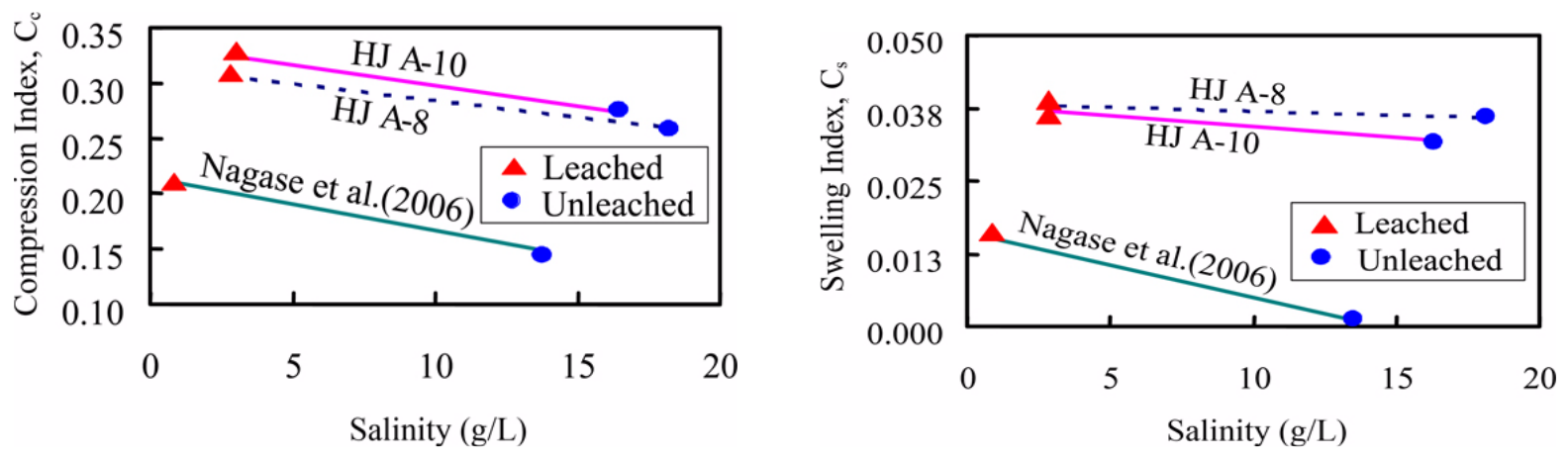

Figure 2-11 Variation of compression index with salinity (right) and variation of swelling index with salinity (left) (Kim \& Do, 2009)

\subsubsection{Effect on shear strength}

Shear strength of soil can be defined as the resistance to shearing stresses and a consequent tendency for shear deformation. Shearing strength can be derived from the resistance due to interlocking of soil particles, frictional resistance between the individual soil grains, and adhesion between soil particles or cohesion.

Torrace (1974) conducted a series of experiments on samples before and after leaching. The natural sample with a salinity of $26 \mathrm{~g} / \mathrm{L}$ was leached to $0.47 \mathrm{~g} / \mathrm{L}$. Figure $2-12$ shows that for leached soil 
shear strength reduction continued up to a large strain. The strength of leached marine clay is less than that of the unleached one.

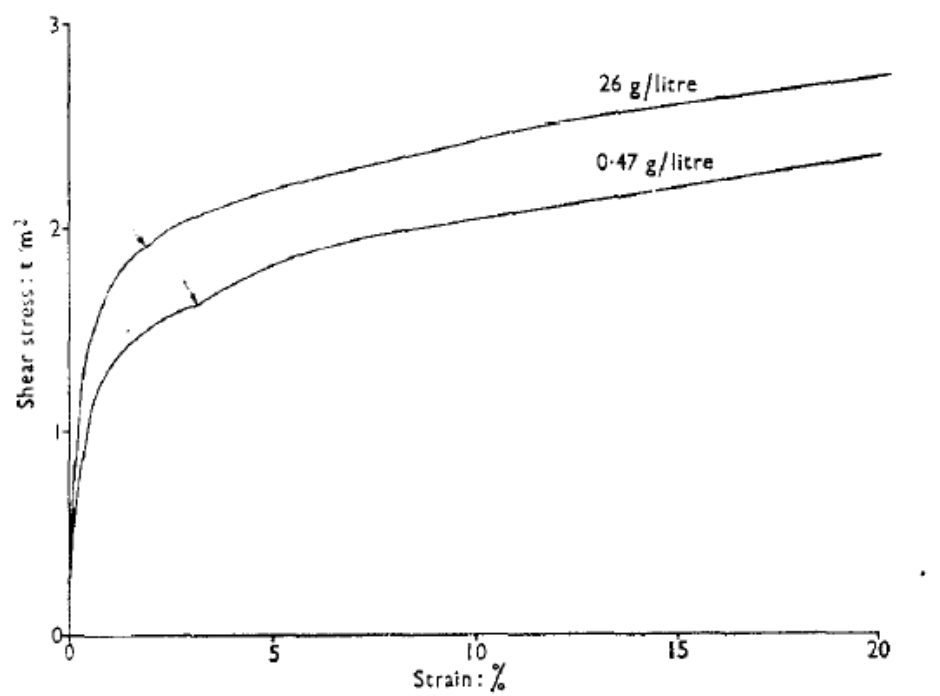

Figure 2-12 Stress-strain curves for leached and unleached marine clays (Torrace, 1974)

Woo \& Moh (1977) investigated the shear strength parameters of soil at different salt concentrations from $35 \mathrm{~g} / \mathrm{L}$ to $7 \mathrm{~g} / \mathrm{L}$. He found that the shear strength parameters decrease when salt concentration goes below $10 \mathrm{~g} / \mathrm{l}$, which is shown in Table 2-4. He also mentioned that reduction of friction angle $(\varphi)$ calculated from angle of inclination, a $(\sin \alpha \alpha=\tan \varphi$ '), indicates that soil become less stable when the salt content in the pore fluid decreased. In Figure 2-13, the triaxial test results are shown briefly as effective stress path and envelops for soils S35 (salt level $35 \mathrm{~g} / \mathrm{l})$ and S7 (salt level $7 \mathrm{~g} / \mathrm{l})$. 


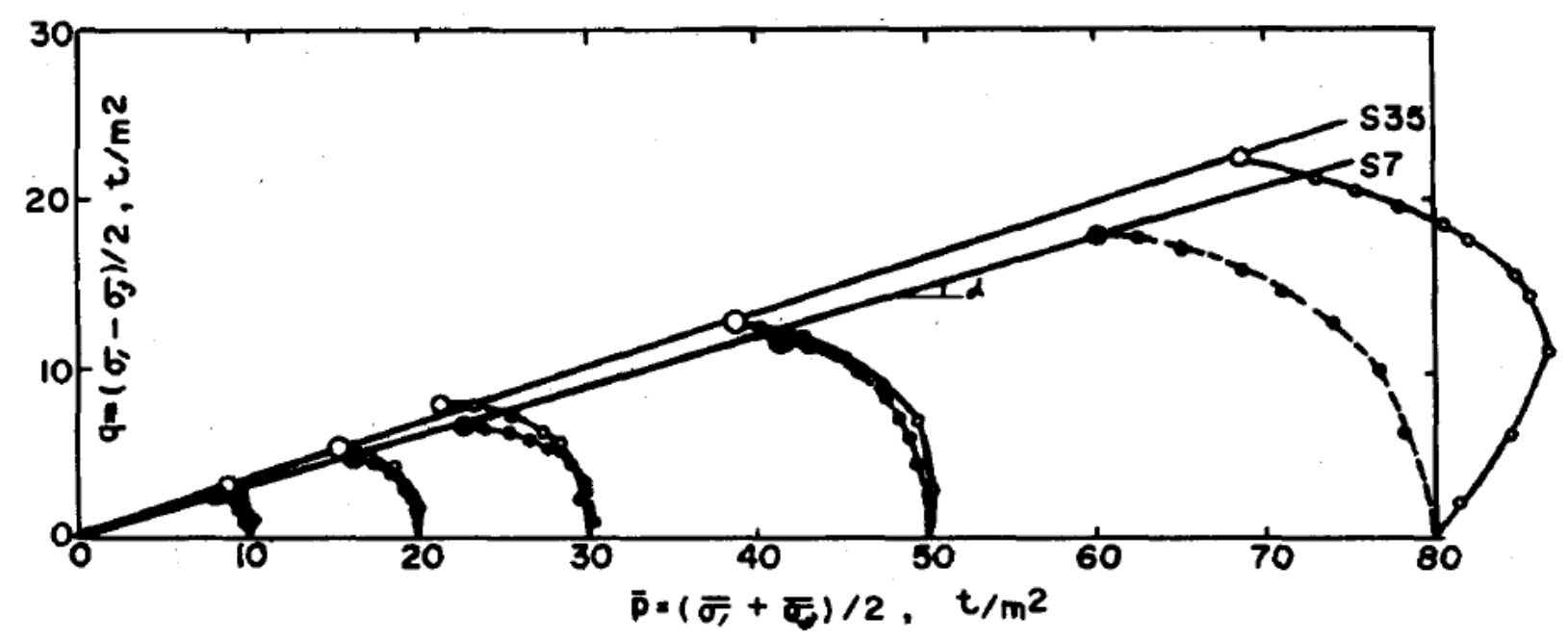

Figure 2-13 Effective stress paths and envelopes of soils S35 (salinity level 35 g/L ) and S7 (salinity level 7 g/L) (Woo \& Moh, 1977)

Table 2-4 Undrained shear strength parameters at different leaching level (Woo \& Moh, 1977)

\begin{tabular}{|c|c|c|c|c|c|c|c|c|}
\hline \multirow{3}{*}{\multicolumn{2}{|c|}{ Type of clay }} & \multirow{3}{*}{$\begin{array}{c}\text { Leaching } \\
\text { Level } \\
(\mathrm{g} / \mathrm{l})\end{array}$} & \multirow{2}{*}{\multicolumn{2}{|c|}{$\begin{array}{l}\text { Total stress at } \\
\left(\sigma_{1}-\sigma_{3}\right)_{\max }\end{array}$}} & \multicolumn{4}{|c|}{ Effect stress } \\
\hline & & & & & \multicolumn{2}{|c|}{ at $\left(\sigma_{1}-\sigma_{3}\right)_{\max }$} & \multicolumn{2}{|c|}{ at $\left(\sigma^{\prime}{ }_{1} / \sigma^{\prime}{ }_{3}\right)_{\max }$} \\
\hline & & & $\alpha$ & $\varphi$ & $\alpha$ & $\varphi$ & $\alpha$ & $\varphi$ \\
\hline \multirow{4}{*}{$\begin{array}{l}\text { Leached } \\
\text { clays }\end{array}$} & S35 & 35 & 12.0 & 12.3 & 18.0 & 19.0 & 19.0 & 20.2 \\
\hline & $\mathrm{S} 25$ & 25 & 11.5 & 11.8 & 19.0 & 20.2 & 20.0 & 21.4 \\
\hline & $\mathrm{S} 10$ & 10 & 11.0 & 11.2 & 17.5 & 18.4 & 18.5 & 19.6 \\
\hline & S7 & 7 & 10.5 & 10.7 & 16.0 & 16.7 & 16.0 & 16.7 \\
\hline
\end{tabular}

Ismael (1993) conducted triaxial tests on natural and leached soil sample and got similar results as Woo \& Moh (1977). There is a reduction in strength due to leaching and the angle of shearing resistance, $\varphi^{\prime}$ was decreased from $36.5^{\circ}$ to $34^{\circ}$ due to leaching, as shown in Figure 2-14. 


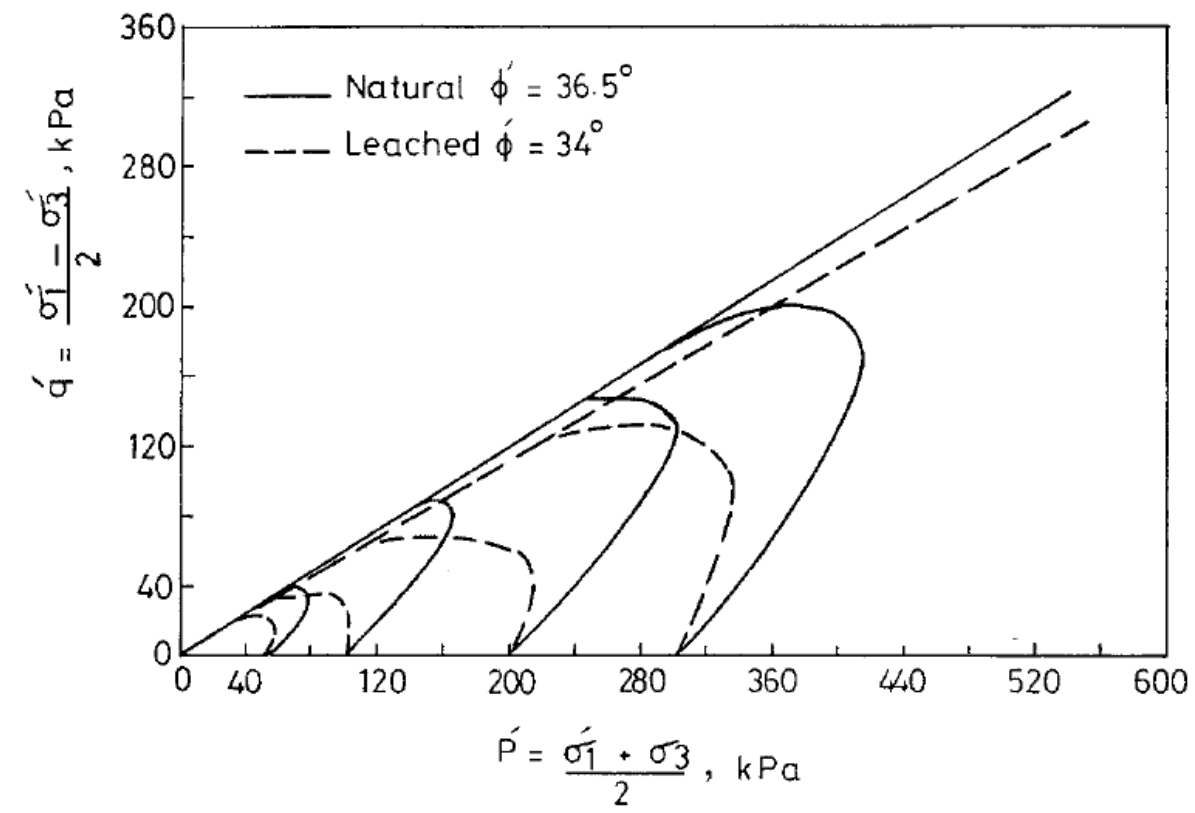

Figure 2-14 Effective stress path and failure envelop for natural and leached specimen (Ismael, 1993)

\subsection{Deep Soil Mixing for Ground Improvement}

Deep mixing method (DMM) is a ground improvement technique that introduces a cementitious binder material mixed to the target soil to improve its strength and compressibility properties. DMM technique was first established in Japan in early 1970s (Kitazume \& Terashi, 2012). The unique advantages of DMM over other ground improvement methods include a quick strength increase, high cost efficiency, minimum environmental disturbance, and wide range of soil applicability (Bruce, 2000). Due to DMM's ability to treat difficult soils, it soon became a popular technique with many applications in the United States, western Canada, and the rest of the world. However, due to the lack of test data DMM has never been applied in Ontario soil.

\subsubsection{Mechanism of binder strength improvement}

The mechanisms of DMM stabilization consists of four stages: 1) hydration of binder; 2) ion exchange reaction; 3) formation of cement hydration product; and 4) formation of pozzolanic product (Kitazume and Terashi 2012). The four stages of cement stabilization, which is presented in Figure 2-15. 


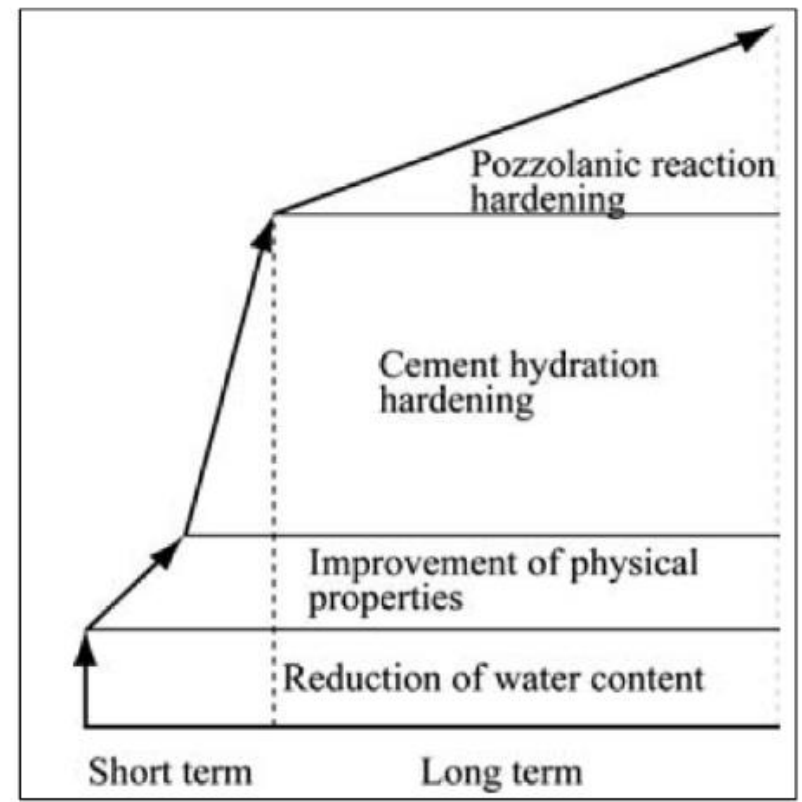

Figure 2-15 Stages of cement stabilization (Kitazume \& Terashi, 2012)

At beginning, water content is being reduced and calcium silicate hydrate $(\mathrm{C}-\mathrm{S}-\mathrm{H})$ produced due to initial cement hydration. This process improves the soil strength over a short period of time. Long-term pozzolanic reaction is activated when more and more calcium hydroxide is being released, and thus produces calcium aluminate and/or calcium silicate to improve soil's strength.

Calcium hydroxide $\left(\mathrm{Ca}(\mathrm{OH})_{2}\right)$ and calcium silicate hydrate $(\mathrm{C}-\mathrm{S}-\mathrm{H})$ are produced and released into the environment as ordinary Portland cement becomes hydrated. Calcium hydroxide also promotes flocculation and agglomeration of the soil, further improving its strength. The following equation demonstrates how tricalcium silicate's and water's reaction to produce C-S-H and calcium hydroxide.

$$
2\left(3 \mathrm{CaO} \cdot \mathrm{SiO}_{2}\right)+6 \mathrm{H}_{2} \mathrm{O}=3 \mathrm{CaO} \cdot 2 \mathrm{SiO}_{2} \cdot 3 \mathrm{H}_{2} \mathrm{O}+3 \mathrm{Ca}(\mathrm{OH})_{2} \quad \text { Equation 2-1 }
$$

Pozzolanic reaction occurs when a high concentration of calcium ions and hydroxyl ions are present at the surface of clay minerals, the mineral's silica and aluminum dissolve into the pore water and react with the calcium ions to form calcium-silicate and/or calcium-aluminate (Kitazume 
\& Terashi, 2012). This reaction produces tough water insoluble gel which improves the long-term strength of soil. Figure 2-16 illustrates a soil particle under pozzolanic reaction.

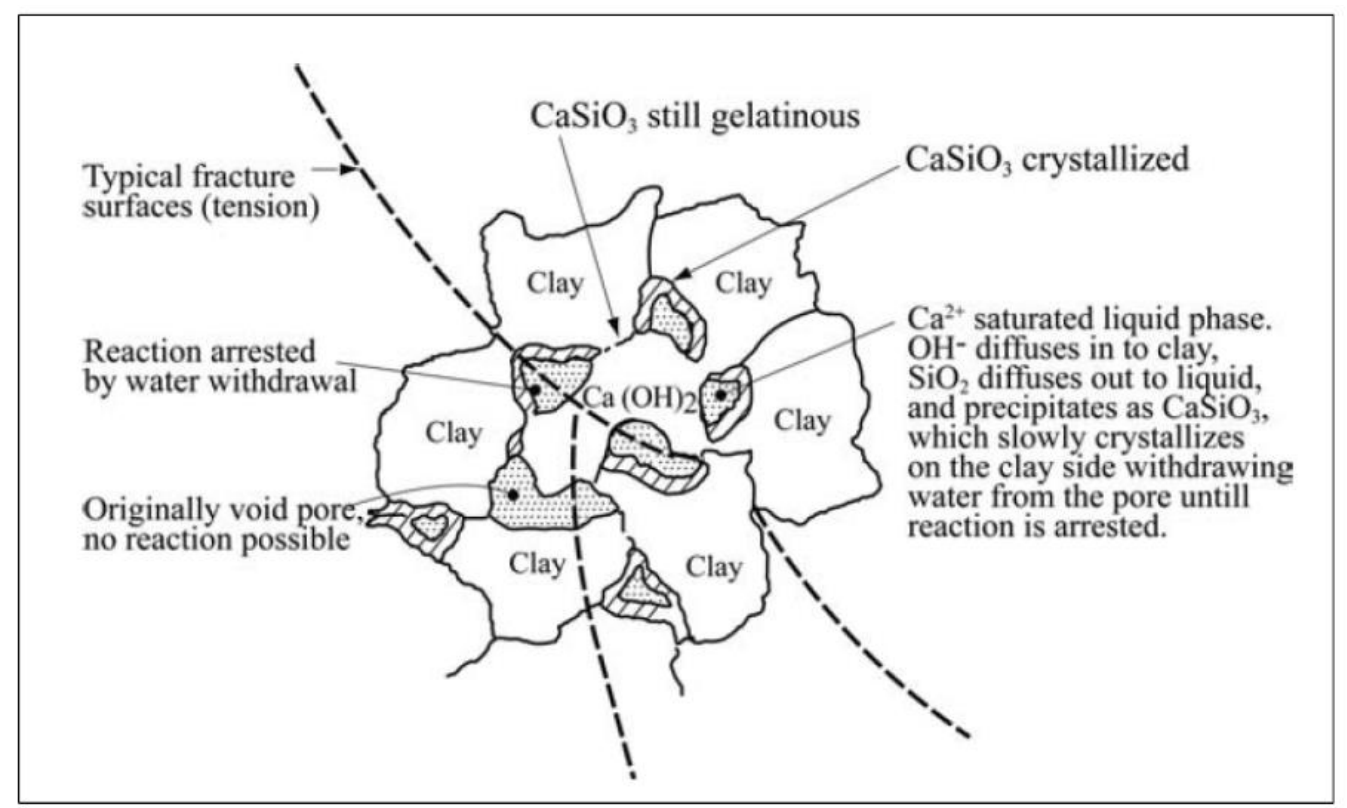

Figure 2-16 Mechanism of pozzolanic reaction (Ingles \& Metcalf, 1972)

\subsubsection{Factors affecting strength increase}

The strength of lime and cement stabilized soils is closely related to chemical reaction between soil and binder. The factors that influences the strength increase can be divided into four categories: 1. Characteristics of binder, 2. Characteristics and conditions of soil, 3. Mixing conditions, and 4. Curing conditions (Kitazume \& Terashi, 2012), which is illustrated in Table 2-5.

Figure 2-17 illustrates the effect of cement content on unconfined compressive strength for 28 days curing. Mitchell (1976) observed that for both fine-grained and coarse-grained soil unconfined compressive strength increases as the cement content increases. It was also reported that as the curing time increases, unconfined compressive strength also increases as shown in Figure 2-18. 
Table 2-5 Factors affecting strength increase (Terashi, 1997)

\begin{tabular}{|l|l|}
\hline Categories of strength increase & Strength increasing factors \\
\hline 1. Characteristics of binder & i. Type of binder \\
& ii. Quality \\
iii. Mixing water and additives
\end{tabular}




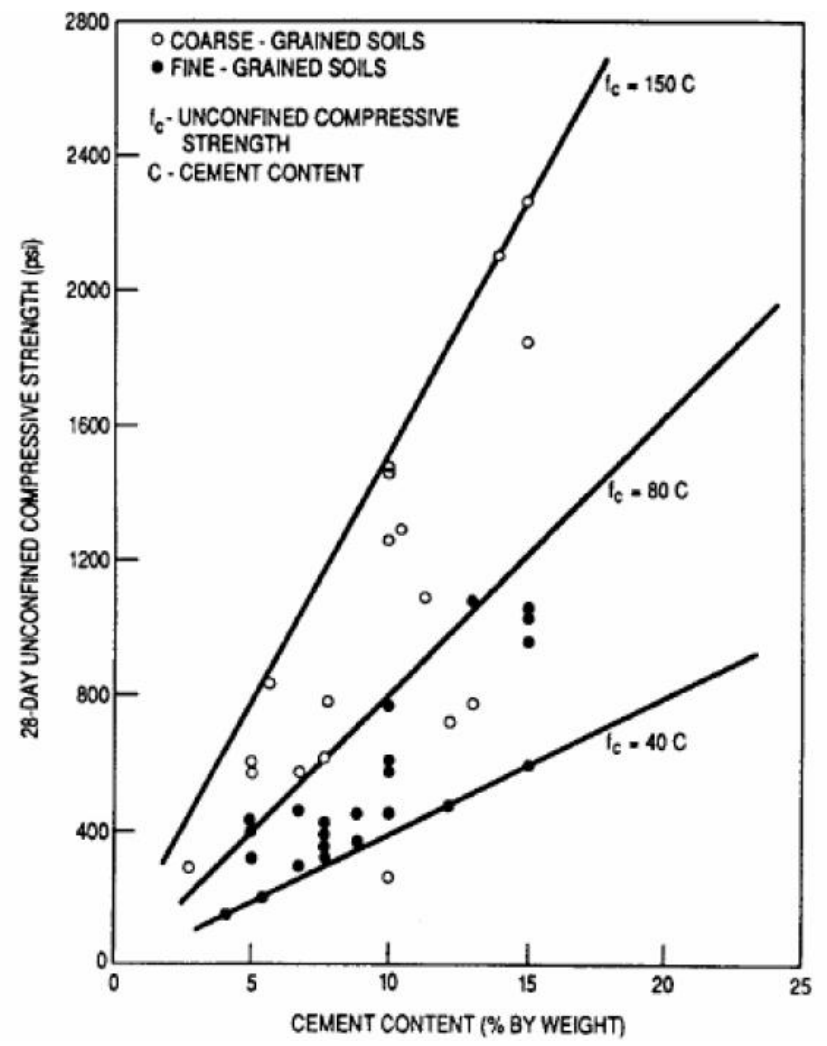

Figure 2-17 Relationship between cement content and unconfined compressive strength for cement treated soils (Mitchell, 1976)

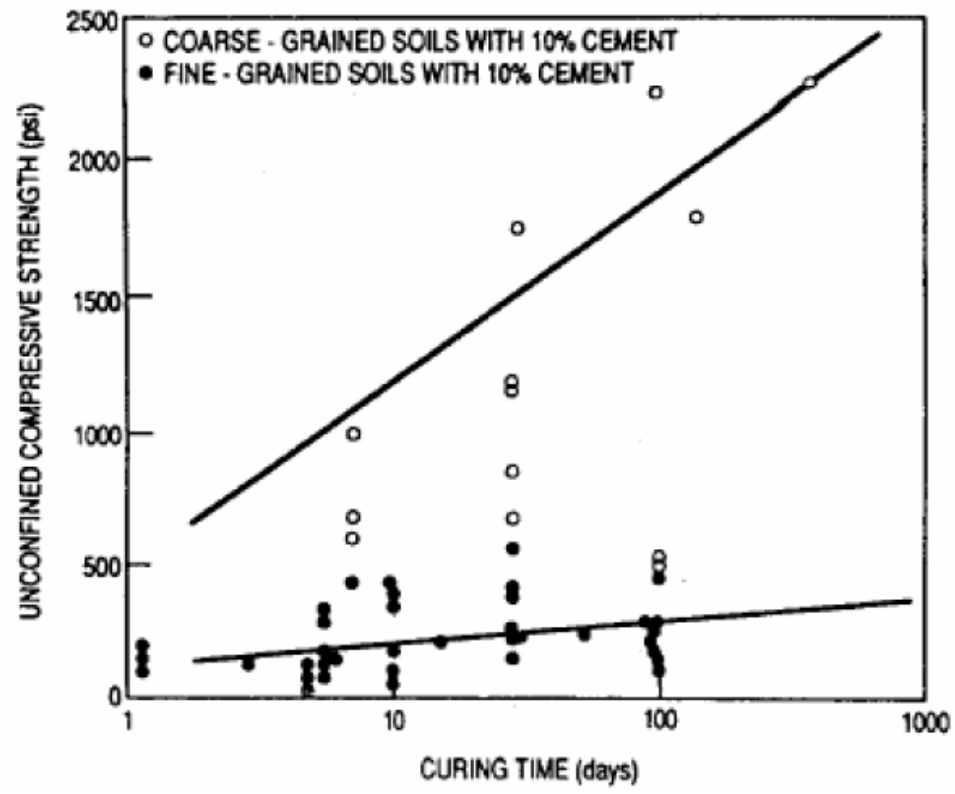

Figure 2-18 Effect of curing time on unconfined compressive strength of cement treated soil (Mitchell, 1976) 


\subsubsection{Effect of total water-to-binder ratio}

Total water-to-binder ratio is defined as the ratio of weight of water in the mixture to the weight of dry binder. It is one of the most crucial factors affecting the strength of DMM sample. Figure 2-19 illustrates the trend of an increasing compressive strength with a decreasing total water-tocement ratio, which includes both dry and wet mixing results. It is evident that this trend of a decreasing strength for an increasing total $w: c$ for deep mixing is the same as for concrete, but $w: c$ values much larger than typical $w: c$ values for concrete (Anon., 2013).

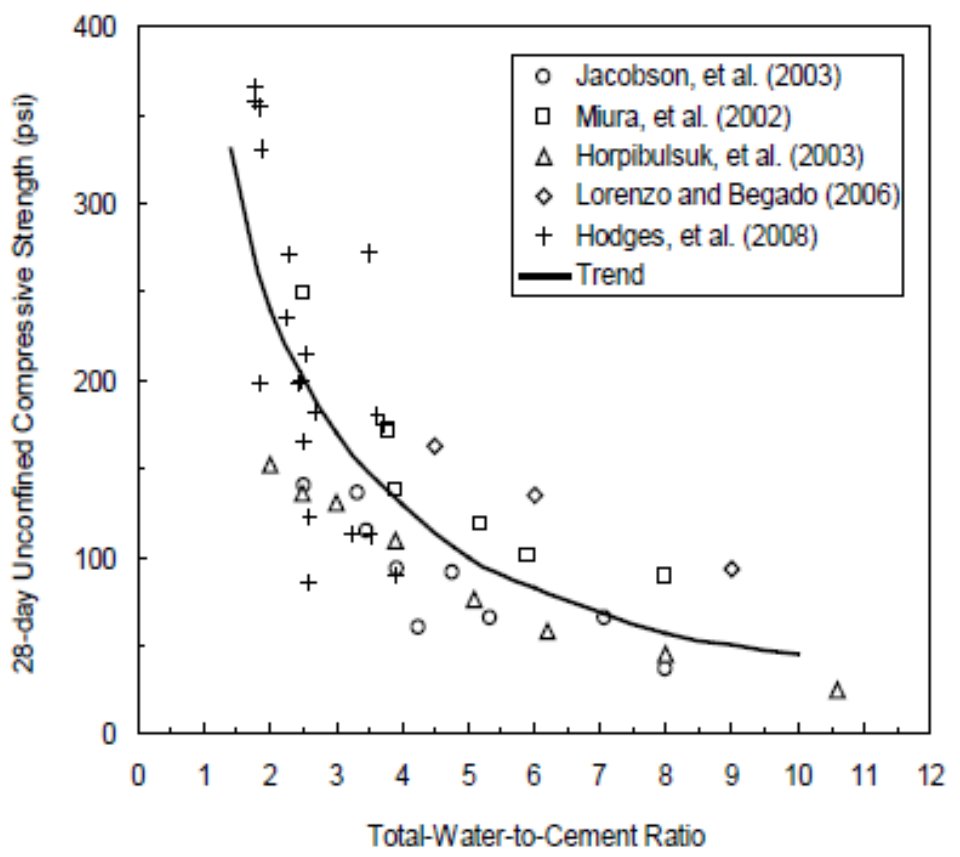

Figure 2-19 Unconfined compressive strength versus total water-to-cement ratio for laboratorymixed and tested specimens (Anon., 2013)

\subsubsection{Improvement of compressibility}

Bergado et al. (1996) reported that there is a significant improvement on the compressibility of cement treated soil, as shown in Figure 2-20. They observed that due to the addition of cement in clay soil sample, the pre-consolidation pressure increases significantly. As the consolidation pressure increases, the coefficient of consolidation gradually decreases with an increasing consolidation pressure. Based on the test results it is evident that a greater value of the coefficient of consolidation can be achieved with a higher cement content as shown in Figure 2-21. 
In most guidelines and manuals in United States, soil with a plasticity index greater than 15 was not recommended for cement stabilization. Prior to cement stabilization, a small amount of lime is recommended to add to soil for the highly plastic clay soil with plasticity index greater than 15 (Muhunthan \& Sariosseiri, 2008).

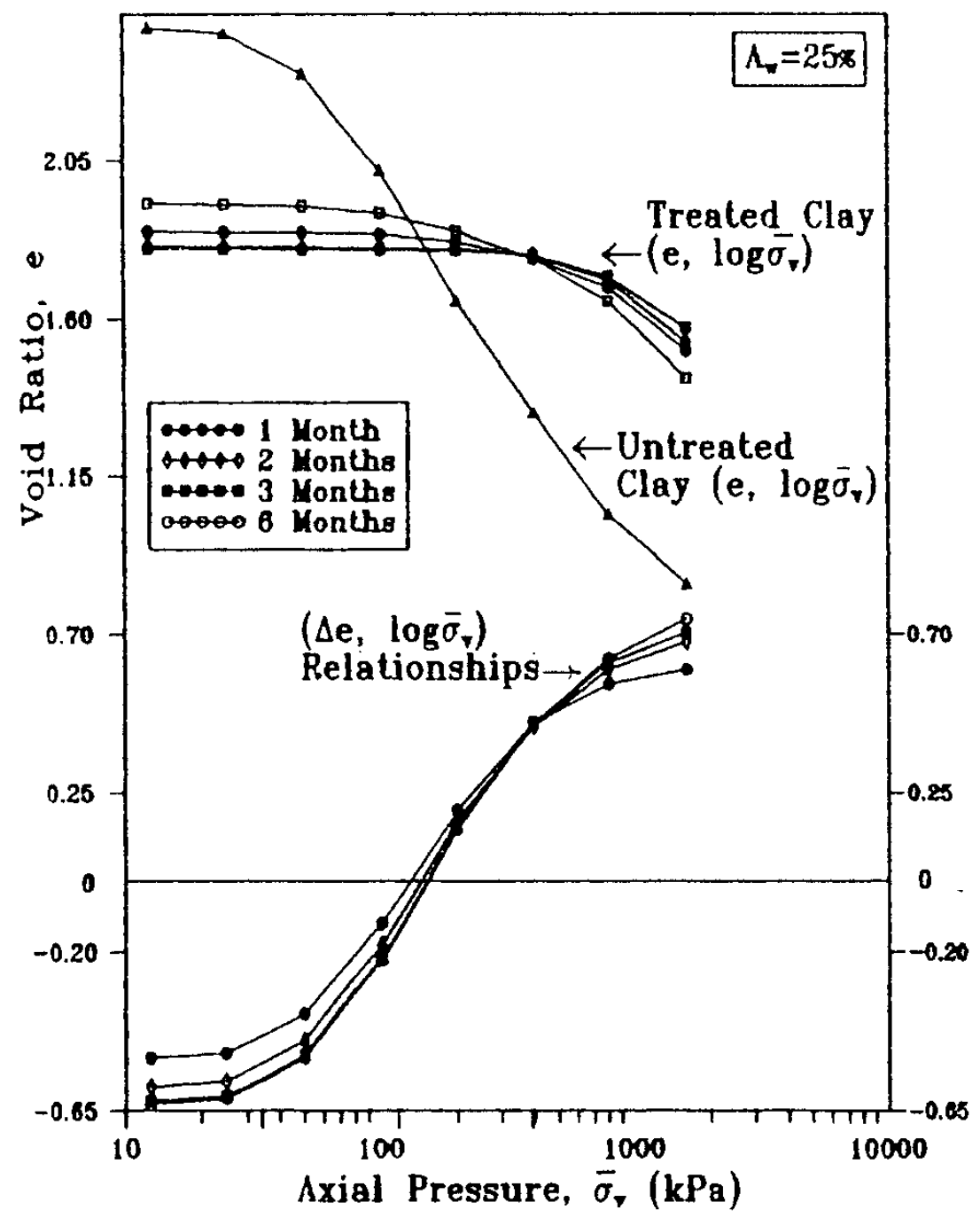

Figure 2-20 Consolidation curve for Bangkok clay with 25\% cement content (Bergado, et al., 1996) 


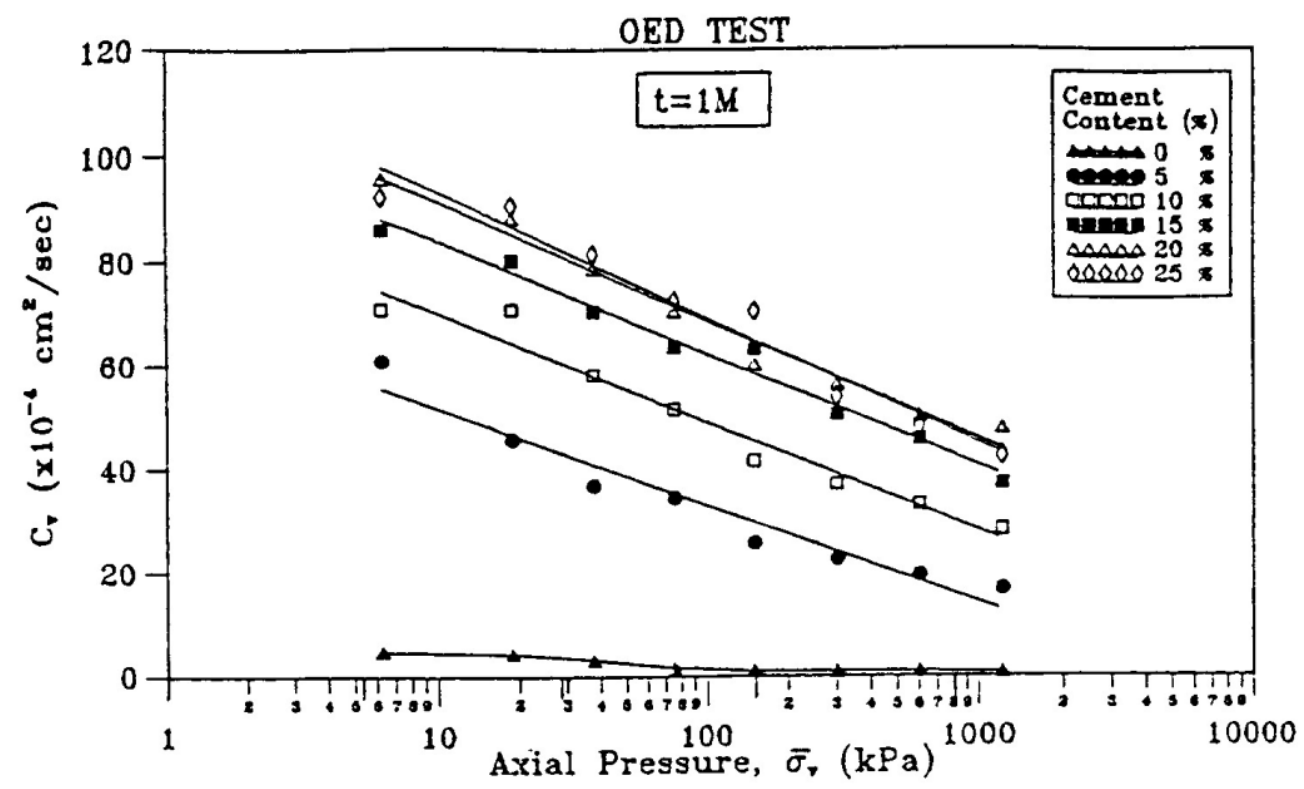

Figure 2-21 Influence of cement content on co-efficient of consolidation (Uddin, et al., 1997)

\subsubsection{Durability}

Attaining an optimum level of durability is desirable in all stabilization projects. Cement treatment is documented to provide resistance against freeze-thaw cycles (Muhunthan \& Sariosseiri, 2008). From the figure 2-22, it evident that as unconfined compressive strength increases, resistance against freeze-thaw cycles increases as well. Therefore, it can be said that with more cement a DMM treated sample becomes more durable with an improved unconfined compressive strength. 


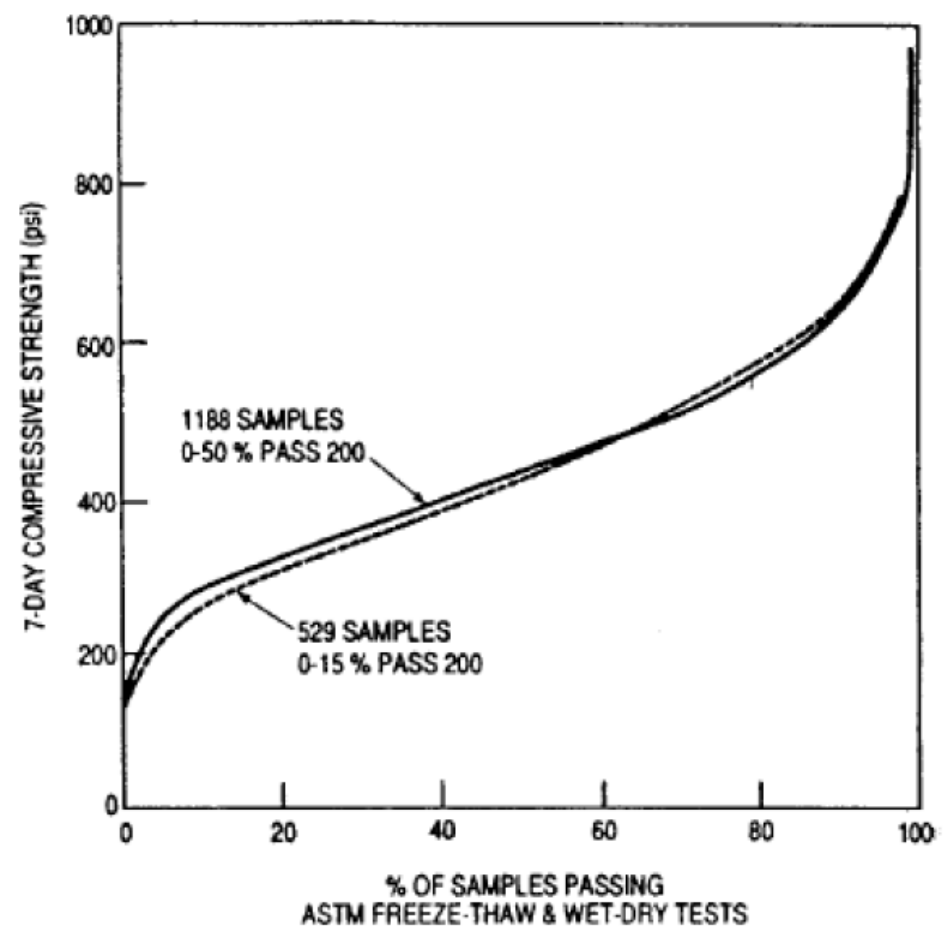

Figure 2-22 Relationship between unconfined compressive strength and durability of cement treated soils based on Portland Cement Association durability criteria (ACI230.1R-90, 1990)

\subsubsection{Applicability of DMM to soft clays}

DMM is one of the most suitable ground improvement methods while dealing with sensitive clay. The method may be used to increase bearing capacity, minimize settlement, prevent slope stability failure, lower seepage of soft ground. Researchers around the world studied the applicability of DMM technique to stabilize sensitive soft clay, but very few from eastern Canada.

Bergado et al. (1996) mentioned that there is significant improvement on the compressibility of cement treated sensitive Bangkok clays.

Locat, et al. (1990) has mentioned that investigations on lime stabilization of sensitive clays are not done often. These results confirmed the viability of using DMM to improve strength of soft sensitive Leda clay. 
Over the last few years, a series of studies have been conducted by the research team at Ryerson University to apply DMM in stabilizing Champlain Sea clay. Li et al. (2016) conducted a series of UCS tests to investigate the effectiveness of cement as a binder to improve the strength of Champlain Sea clay. Samples were collected from the sites near the City of Ottawa. The authors mentioned in their report that a minimum dosage of $5 \%$ by weight is required to have meaningful improvement in the UCS of the sample. It was also mentioned in the report that the strength of the samples increases with an increase in both cement dosage and curing period.

Ahmad (2018) performed a series of constant rate of strain (CRS) tests on Champlain Sea clay samples extracted near the City of Ottawa. The purpose of his tests was to study the compressibility behaviour of cement-treated leached and native Champlain Sea clay soil under different leaching conditions. In his research, he used $50 \mathrm{~kg} / \mathrm{m}^{3}$ dosage of cement by weight which roughly translated to $5 \%$ dosage by weight. He mentioned in his report that an inclusion of cement at $50 \mathrm{~kg} / \mathrm{m}^{3}$ dosage to the native Champlain Sea clay decreases the compressibility of the soil sample to a considerable amount. A sample test result can be seen in Figure 2-23 where after treated with cement the coefficient of compressibility is decreased from 2.32 to 0.43 . i.e. a more than $80 \%$ reduction in the compressibility.

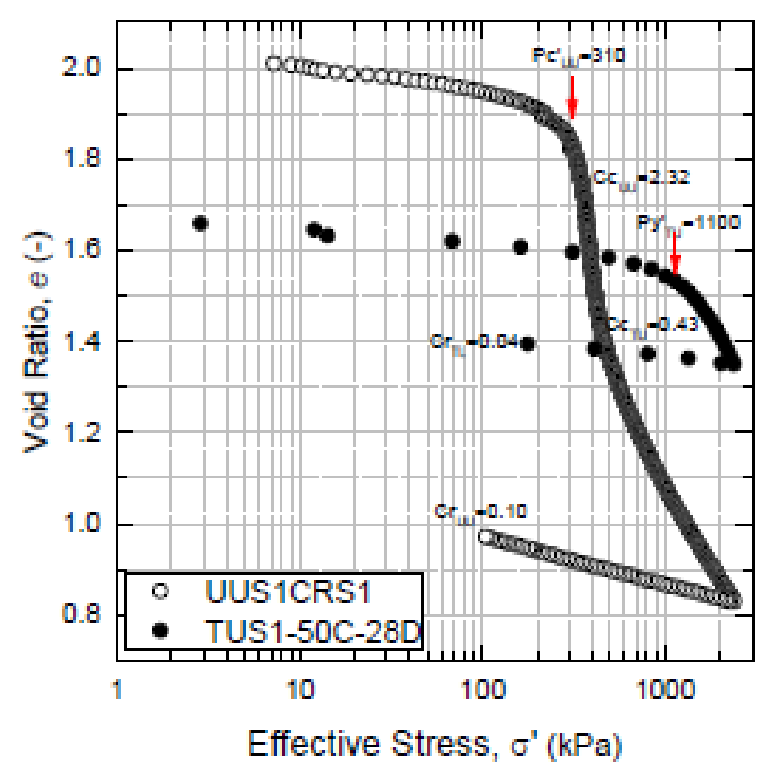

Figure 2-23 Comparison on the compressibility of a native sample and a cement treated sample (Ahmad, 2018) 


\subsubsection{Triaxial tests for stabilized clay}

Triaxial testing for stabilized clay is occasionally conducted in North America and no standard has been developed till to date. Triaxial testing is being mentioned by some researchers. Uddin, et al. (1997) conducted a series of CIU triaxial test on cement-treated Bangkok soft clay. Cement content ranging from $5 \%$ to $40 \%$ by weight were used to prepare cement treated clay samples. From the test results the authors claimed that cement that was introduced to the soft clay increased the peak deviator stress and increased soil modulus. They also found that the more the cement content was used the more peak deviator stress and higher modulus obtained due to the cementitious bond formed between soil and cement, as shown briefly in Figure 2-24. The authors also mentioned about the cement-mixed clay soil samples p-q' stress path of the CIU tests. They mentioned that cement mixing changed the stress path of the soft clay due to change in soil consolidation where the normally consolidated samples became over-consolidated soil as shown in Figure 2-25.

\section{CIU TESTS}

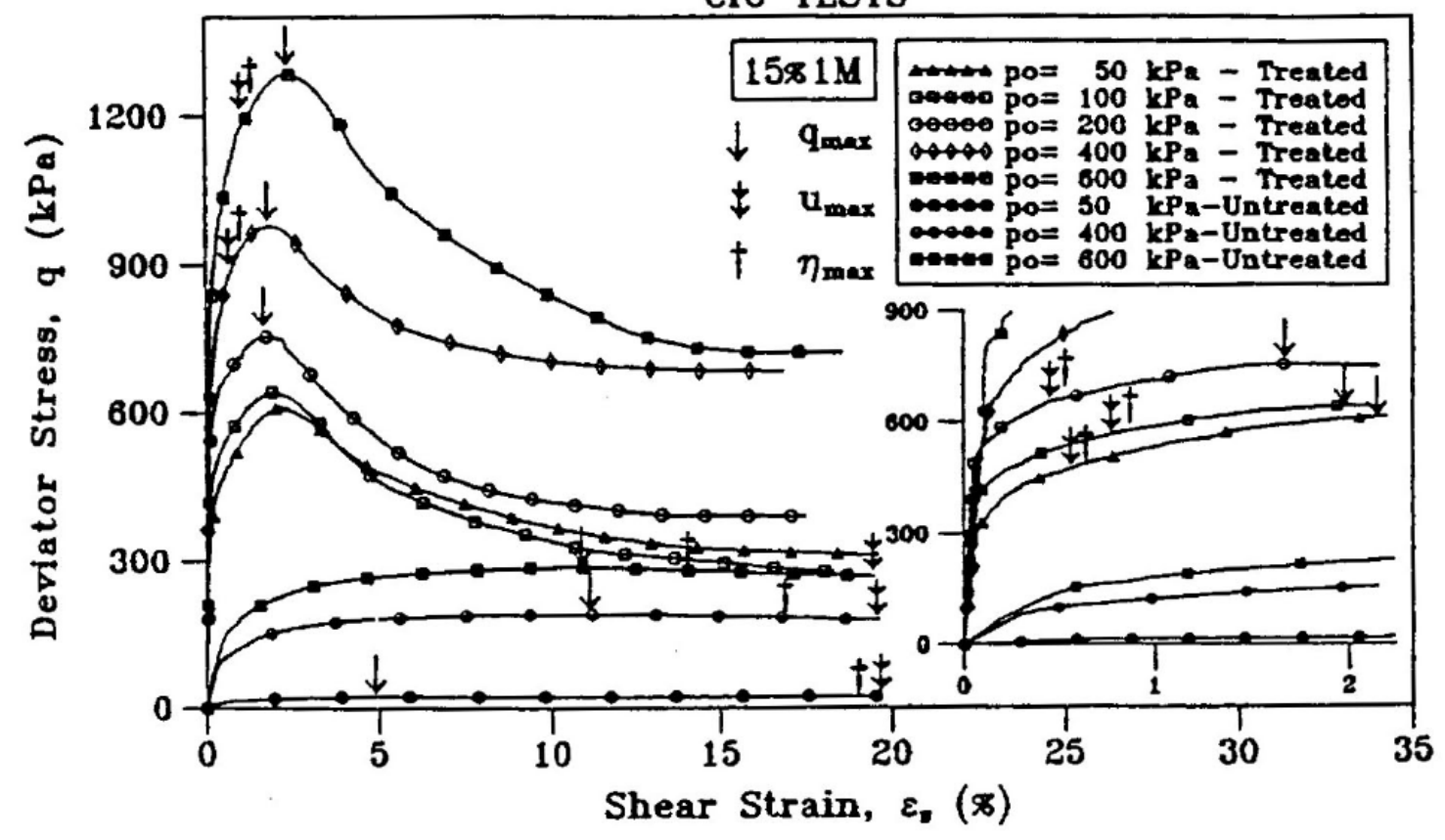

Figure 2-24 Stress- strain curve for the cement-treated Bangkok clay samples (Uddin, et al., 1997) 


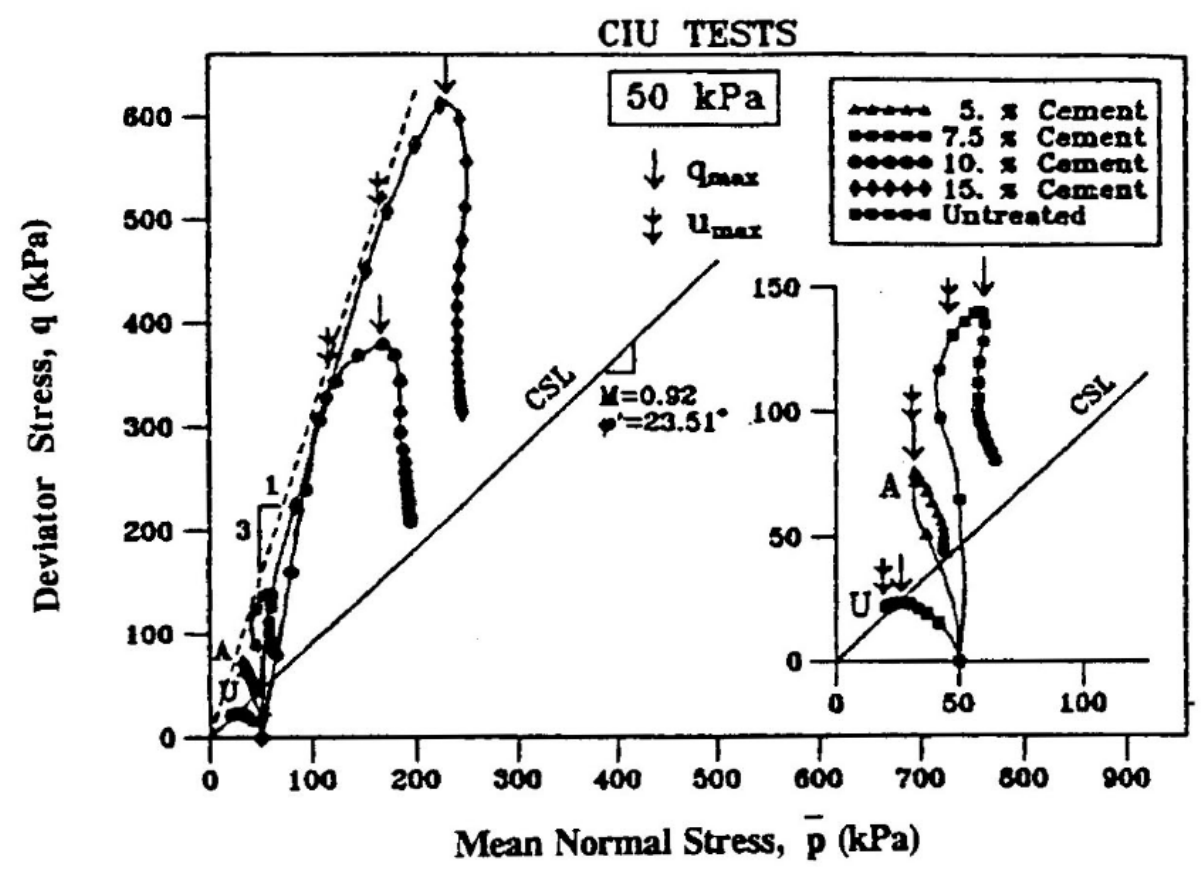

Figure 2-25 Undrained Stress-path for cement-treated Bangkok clay (Uddin, et al., 1997)

Åhnberg (2006) investigated the influence of back pressure and strain rate on stabilized soils. It was mentioned that back pressure has a significant affect on the measured strength of stabilized soil. A low back pressure of $20 \mathrm{kPa}$ for short-term condition and a high back pressure of $400 \mathrm{kPa}$ for long-term conditions were reported. Different back pressures affect the degree of saturation, the higher the back pressure, the higher the degree of saturation, vice versa.

Baker (2000) conducted triaxial tests on stabilized clay samples. In his report, he mentioned that as the curing period increases, the strength increases, and the stiffness and modulus $\left(E_{m o d}\right)$ increase as well. The modulus $\left(E_{m o d}\right)$ obtained from triaxial tests is slightly higher than that obtained from unconfined compressive tests (Baker, 2000).

Amin (2015) conducted a series of triaxial tests on cement and cement/lime stabilized clay samples. A $100 \mathrm{~mm}$ height and $50 \mathrm{~mm}$ diameter triaxial test samples were used in his studies. He used a cylinder of the same diameter of the sample preparation and compacted that with the sample in three lifts, and then stored in a refrigerator at $7^{\circ} \mathrm{C}$ by sealing the end faces of sample with a tape. 


\subsection{Leaching Impact on Cement-Treated Soft Clay}

The leaching impact on cement-treated soft clay was hardly reported by the researchers. Ahmad (2018) conducted a limited number of CRS tests on cement-treated leached Champlain clay samples. First, a native clay sample was leached by flushing distilled water through and reduced salinity from $19.81 \mathrm{~g} / \mathrm{L}$ to 0.79 from. Second, a cement dosage of $50 \mathrm{~kg} / \mathrm{m}^{3}$ using wet mixing method (water to cement ratio of slurry is 1:1) was applied to mix with the leached clay sample. Third, the author prepared the CRS test sample and then let it cure. CRS tests were conducted at strain rate of $0.8 \%$ and $1 \% / \mathrm{hr}$. The strain rate had very little to no influence on the test results as reported. It was mentioned that the salinity level has affect on the cement compressibility improvement. According to the author, cement-treated leached Champlain Sea clay samples exhibit better compressibility behaviour compared to the cement-treated unleached samples. The author also mentioned that as the more the curing days the better compressibility behaviour was observed from the test results as shown in Figure 2-26 \& 2-27. The author also reported that the curing days has no effect on the permeability of leached treated Champlain Sea clay samples as he tested permeabilities for $2,7 \& 28$-day curing periods. Throughout the research conducted by Ahmad (2018), two different salinity levels of 19.81 and $0.79 \mathrm{~g} / \mathrm{L}$ were only investigated on Champlain Sea clay. The comprehensive impact of salinity on the compressibility of native and treated samples is still unknown and requires further investigation. 


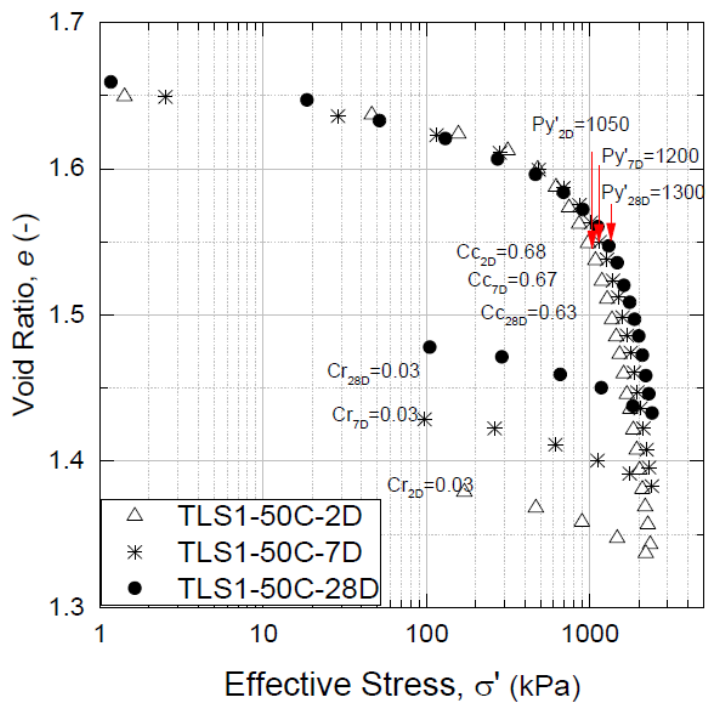

Figure 2-26 e-log p curves of treated leached samples due to curing (Ahmad, 2018)

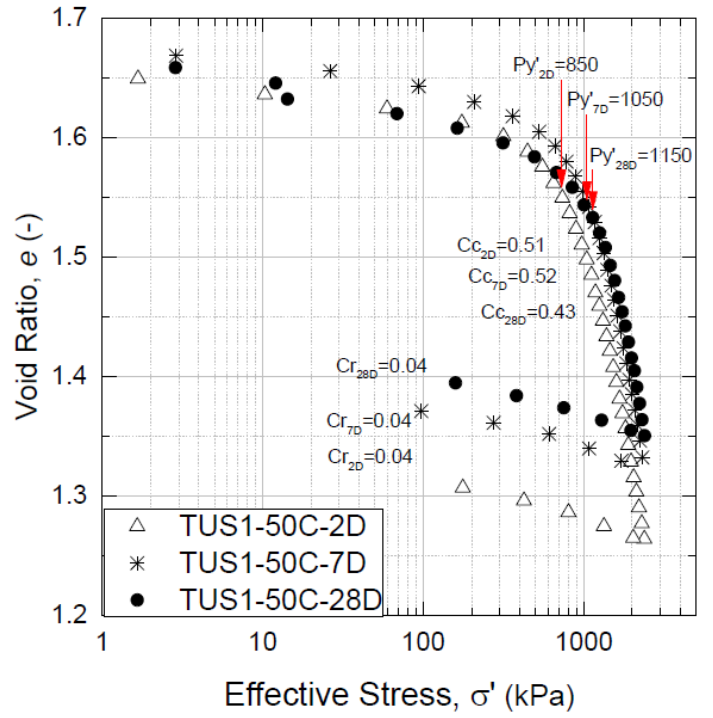

Figure 2-27 e- $\log \mathrm{p}$ curves of treated unleached samples due to curing

(Ahmad, 2018)

\subsection{Summary}

This chapter introduced the formation, index, sensitivity, shear strength and compressibility of properties of soft sensitive clays including Champlain Sea clay. Impact of leaching on the sensitivity, index, shear strength and compressibility of soft clays were also addressed. Moreover, deep mixing method (DMM) as the treatment method to improve the strength and compressibility properties of the soft marine clay around the world including Champlain Sea clay was reviewed.

However, the investigation of the effect of different levels of pore fluid salinity on the strength and compressibility behaviour on the cement mixed sensitive Champlain Sea clay is scarce. Therefore, geotechnical investigation in this area is significant. 


\section{EXPERIMENTAL PROGRAM}

\subsection{Introduction}

This chapter first presents some index properties, undrained shear strength and the sensitivity of the Champlain Sea clay sample used in this study. Next, leaching process of undisturbed Champlain Sea clay will be explained. Then, some physical and chemical properties, undrained shear strength, the sensitivity of the leached soil will be presented compare with those of undisturbed unleached samples. In addition, the procedures for sample preparation of the DMM clay will be discussed. Finally, the formula and the parameters used to interpret the test results of CRS and triaxial will be explained.

\subsection{Index Properties of Undisturbed Champlain Sea Clay}

\subsubsection{Grain size distribution}

In soil mechanics, grain size distribution is used to quantify the size of grains in a type of soil. In this study, the Champlain Sea clay samples were obtained from 20 to $25 \mathrm{~m}$ depth of foundation of Waba dam, near Ottawa city. A sieve analysis was performed on the Champlain Sea clay sample at $22.20 \mathrm{~m}$ depth according to the ASTM D422 specification, as shown in Figure 3-1.

\subsubsection{Atterberg limits}

The Atterberg limits are known as a basic measure of the critical water contents of a fine grained soil. The Atterberg limits test were conducted according to ASTM D 4318 (ASTM, 2017) on clay samples. Liquid limit obtained in the study area are ranging from 80 to 84 , and plastic limit from 28 to 35 . The results obtained from the native soil sample are almost identical to the results reported by Liu et al. (2017) at the similar depth as seen in Figure 3-2. 


\subsubsection{Soil classification}

A plasticity chart for Champlain Sea clay for different depth was formed by Liu, et al. (2017) as shown in Figure 3-3. Test results shows that the clay sample in the study area falls in the $\mathrm{CH}$ part (Clay with high plasticity) of the plasticity chart.

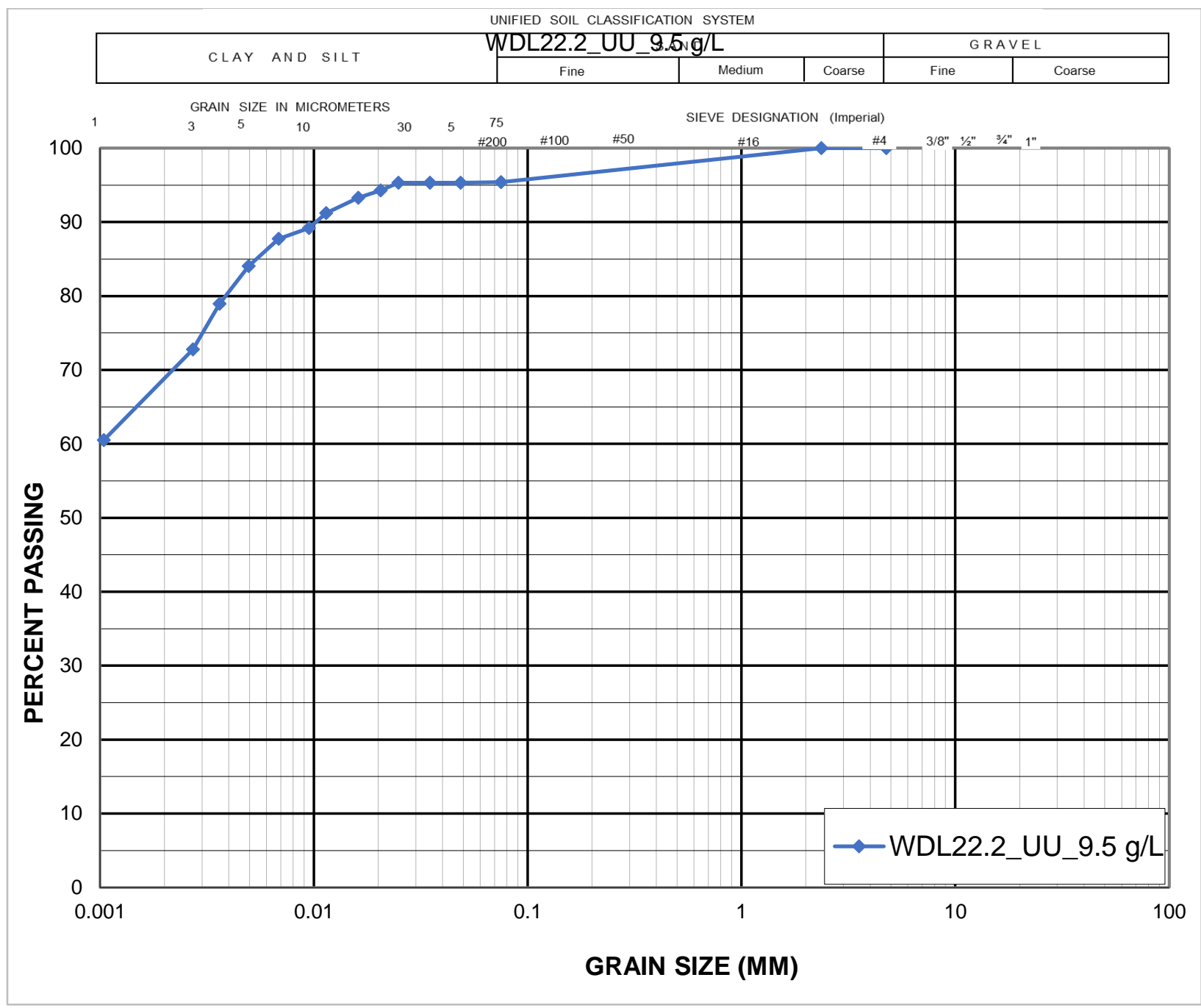

Figure 3-1 Grain size distribution of Chaplain sea clay at 22.20m depth

\subsubsection{Undrained shear strength}

Undrained shear strength can be defined as the magnitude of the shear stress that a soil can sustain at an undrained condition. In this study, mini vane undrained shear strength tests were conducted at depth from 20 to $25 \mathrm{~m}$ according to the ASTM D4648/ D4648M specification. Test results shows 
that the undrained shear strength varies from 35 to $45 \mathrm{kPa}$ as shown in Figure 3-4. Similar results were reported by Liu et al. (2017).

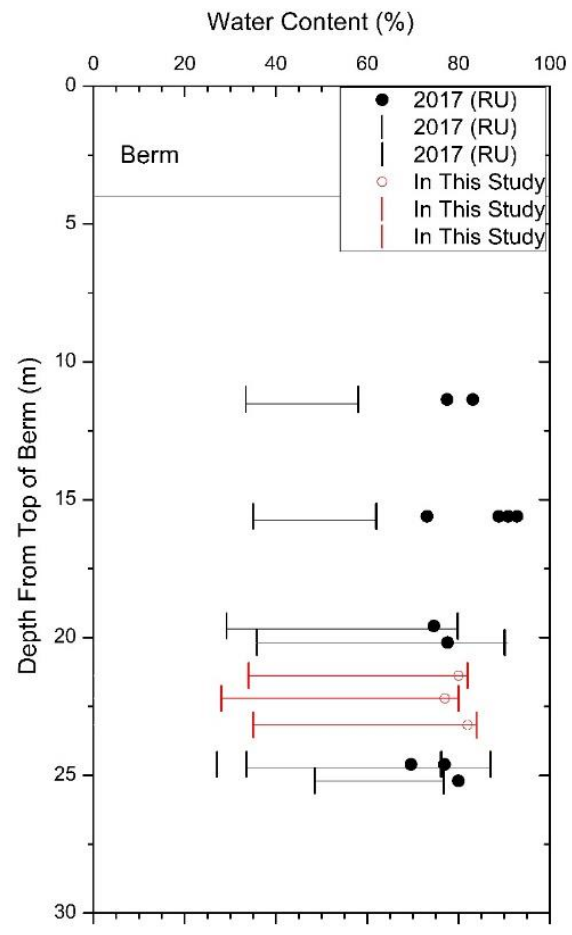

Figure 3-2 Atterberg limit at different depth of Champlain Sea clay soil (Liu, et al., 2017) 

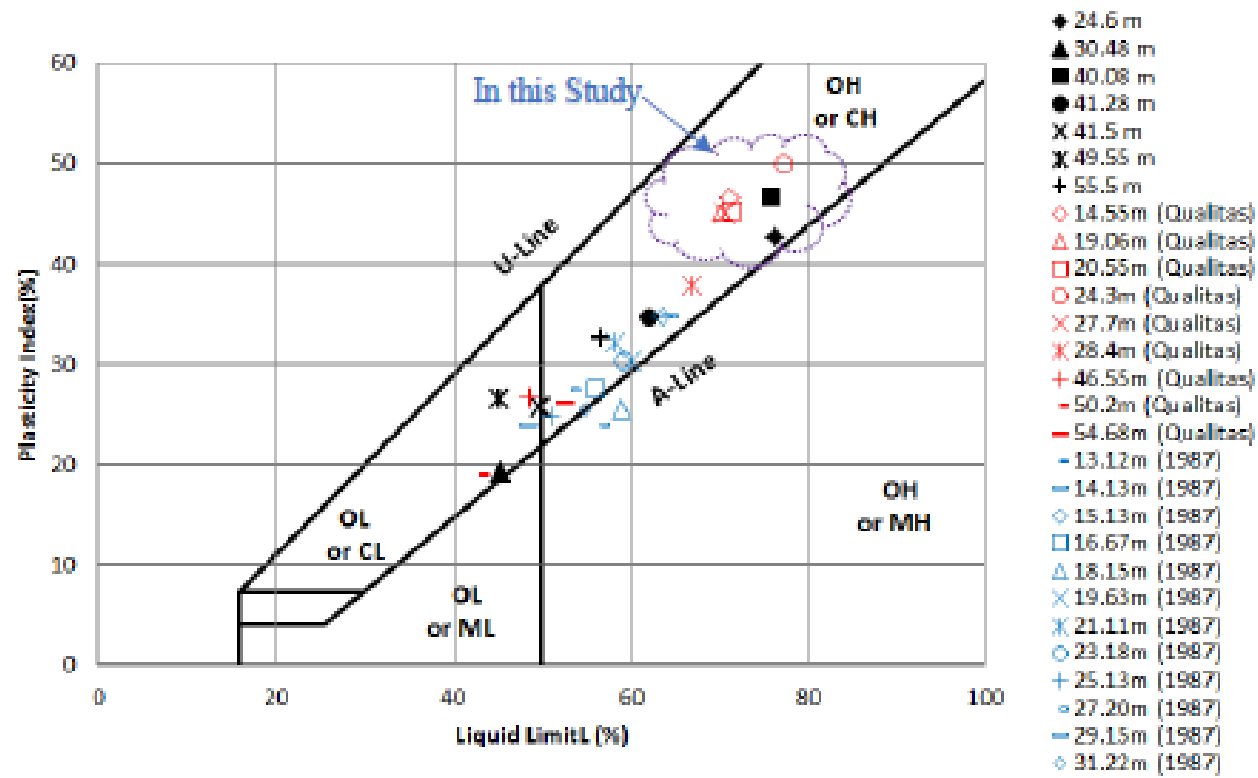

Figure 3-3 Soil classification at different depth of Champlain Sea clay soil sample (Liu, et al., 2017)

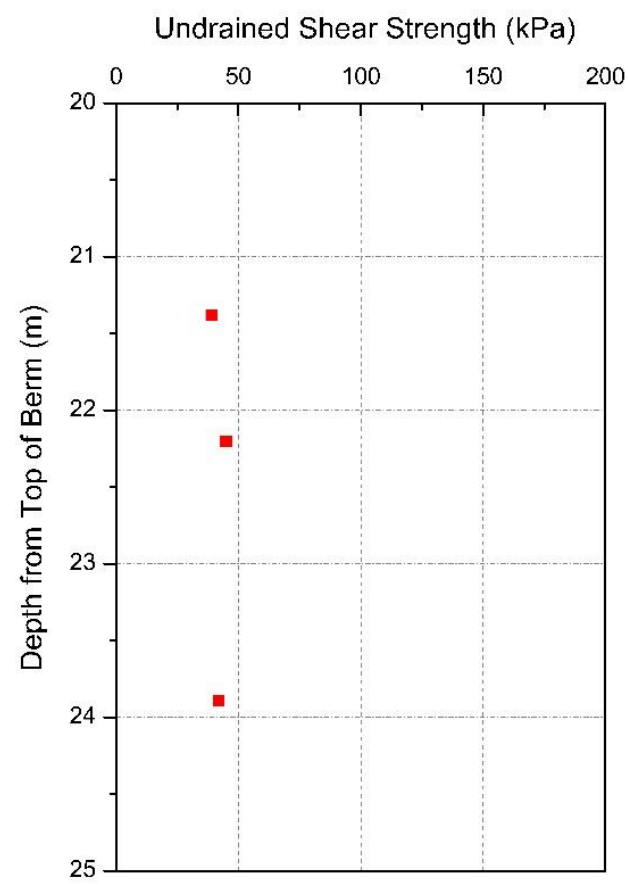

Figure 3-4 Undrained shear strength of Champlain Sea clay at different depth 


\subsubsection{Sensitivity}

Sensitivity is calculated as the ratio of the undrained shear strength of the undisturbed clay and the undrained shear strength of the remoulded clay. In this study, mini vane undrained shear strength tests for both undisturbed and remolded soil samples were conducted according to the ASTM D4648/ D4648M specification. Test results reveal that sensitivity of Champlain Sea clay in the study area varies from 4 to 10 which fall in region of highly sensitive to extra sensitive zone as shown briefly in Figure 3-5.

\subsubsection{Specific gravity}

The specific gravity can be defined as the ratio of the unit weight of soil solids to the unit weight of water. The average specific gravity of the clay was determined 2.67 from the tests performed according to ASTM D854 (Ahmad, 2018).

\subsubsection{Salinity}

Salinity can be defined as the amount of dissolved salts present in the soil. Clay soil salinity was measures by the diluted fluid method. First, the clay sample was dried in the oven. Second, known mass of the soil sample was mixed with distilled water. Third, the salinity level was recorded using salinity meter. The salinity of the study area varies from 9.5 to $15 \mathrm{~g} / \mathrm{L}$, as shown in Figure 3-6. 


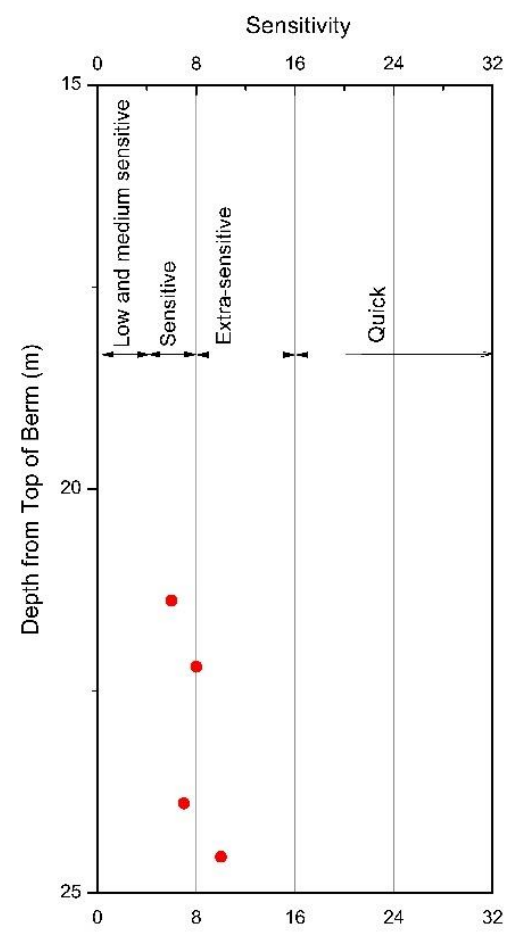

Figure 3-5 Sensitivity of Champlain Sea clay soil at different depths

\subsubsection{Summary of index properties}

Index properties of the Champlain Sea clay soil at depth 20 to $25 \mathrm{~m}$ are summarized in the Table below.

Table 3-1 Index properties of unleached Champlain Sea clay used in this study

\begin{tabular}{|c|c|}
\hline Soil Classification & CH (Clay with high plasticity) \\
\hline Water Content (\%) & $75-82$ \\
\hline LL (\%) & $78-85$ \\
\hline PL (\%) & $28-35$ \\
\hline Undrained Shear Strength (kPa) & $38-50$ \\
\hline Sensitivity (MV) & $6-10$ \\
\hline Salinity (g/L) & $9.5-15.0$ \\
\hline
\end{tabular}




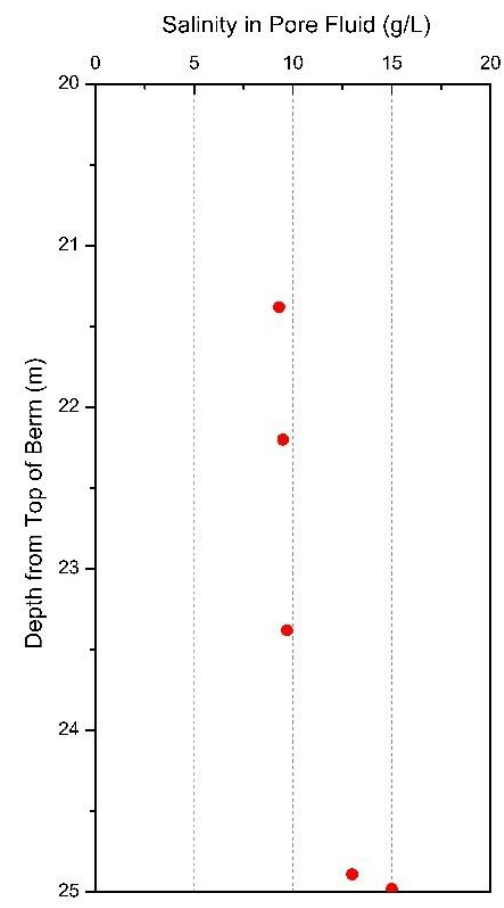

Figure 3-6 Salinity of Champlain Sea clay at different depth

\subsection{Clay Sample Leaching}

\subsubsection{Leaching procedure}

The objectives of leaching tests are to obtain the impact of salinity on the index properties, compressibility, and strength parameters of Champlain Sea clay by conducting a series of CRS, triaxial, and vane shear tests along with other tests. The clay samples are being leached by flowing DDW through the samples to reduce their salinity levels. During the leaching process, the leachate was collected in a beaker, the leached amount and the salinity level were recorded using a portable salinity meter within an interval of 24 to 48 hours. Each time, after recording, the beaker was replaced with another clean beaker. The process was repeated during the whole leaching period. A schematic diagram of the leaching test procedure is shown in Figure 3-7.

The whole leaching process can be divided into three stages. In Stage 1, usually within 7 to 15 days, the salt level remained the same as the unleached sample. In Stage 2, the salt was decreased 
radically between 15 to 35 days after the start of leaching. In Stage 3, a decrease in salinity was at a much slower at the time goes by, which was also mentioned by another researcher (Ahmad, 2018). The amount of leached collected from the test was not equal all the time because of different collection times.

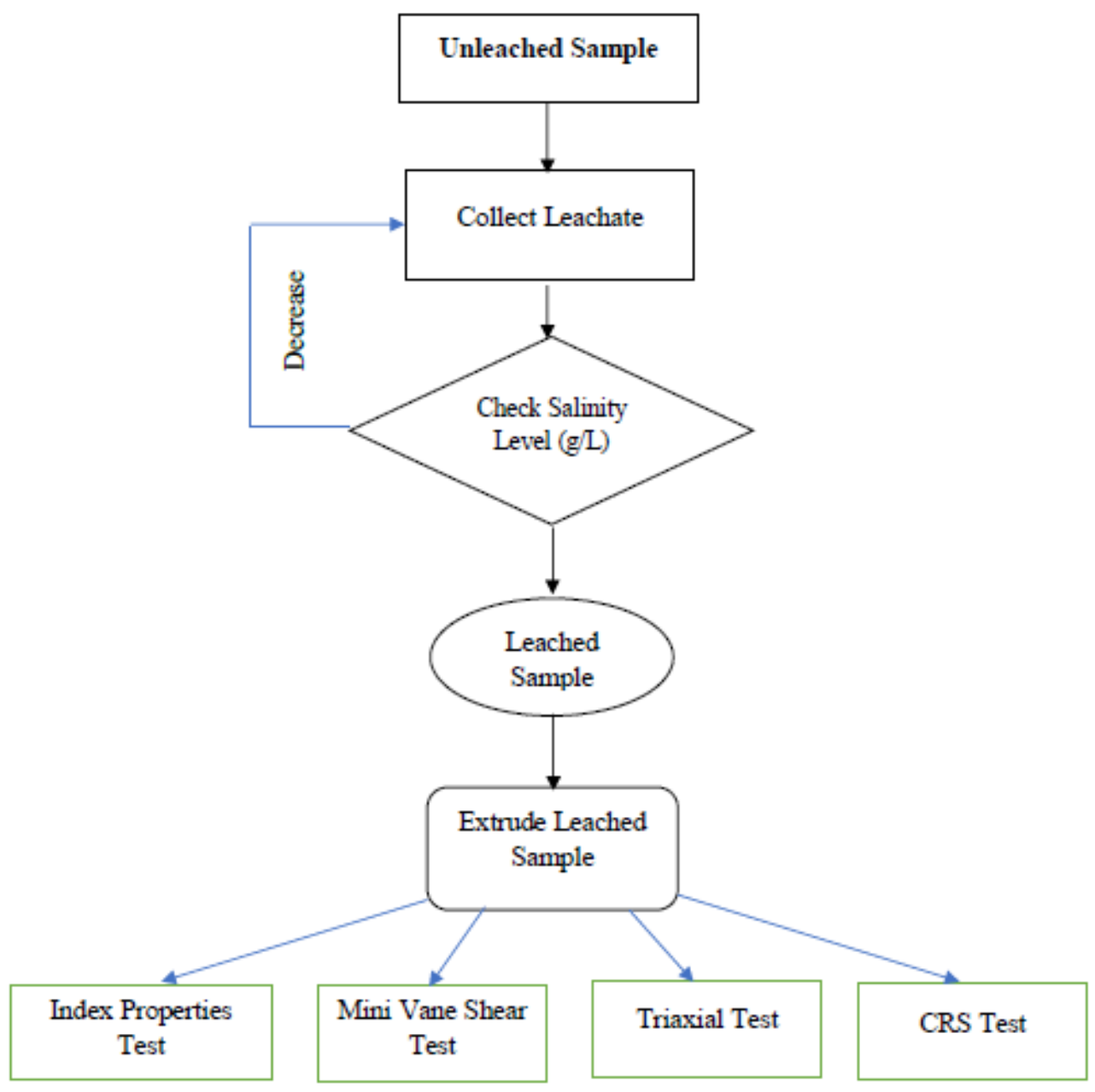

Figure 3-7 Schematic diagram of the leaching test procedure 


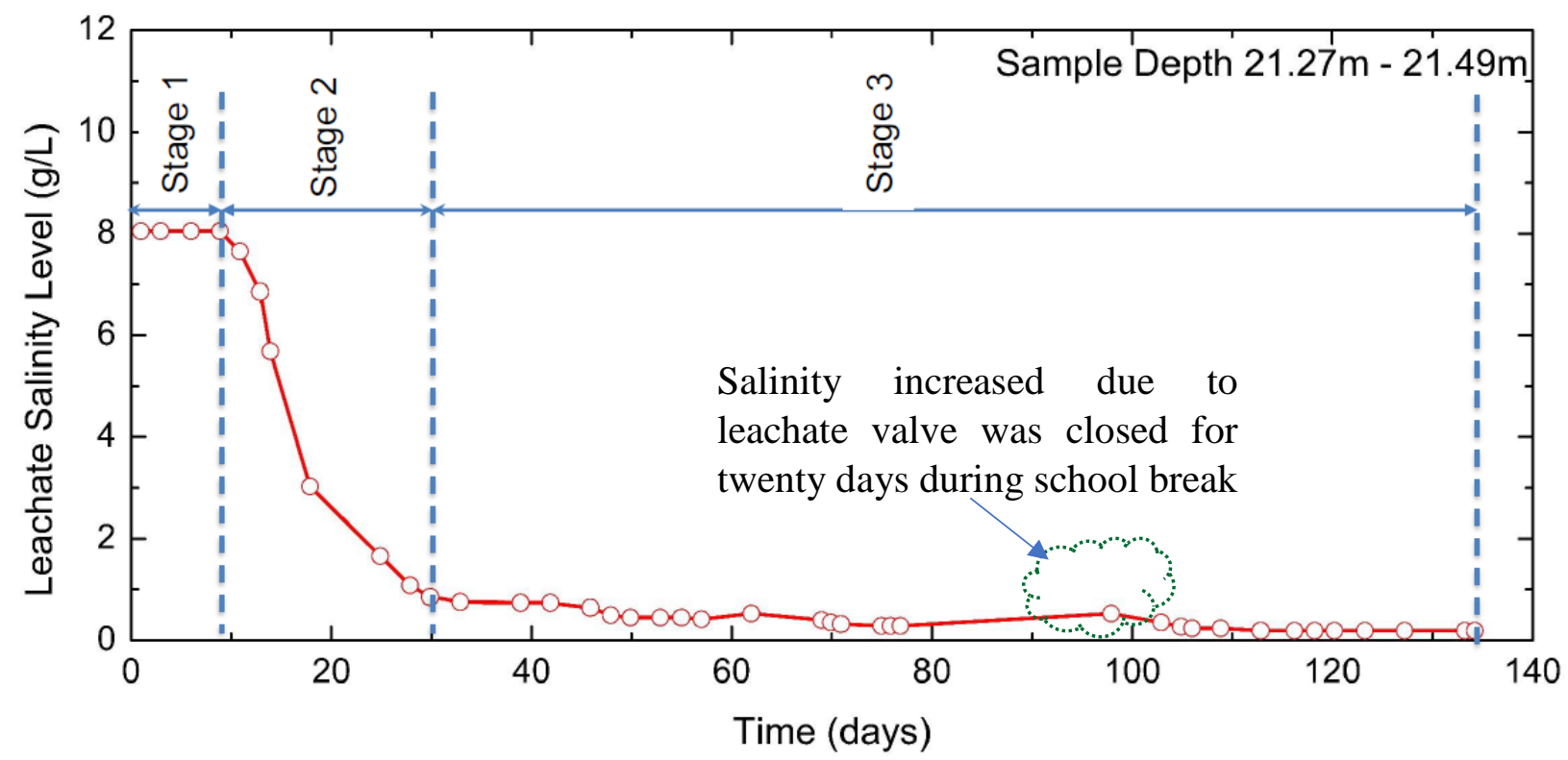

Figure 3-8 Typical graph showing decrease in percentage of salinity level in the collected leachate during the leaching period

It should be mentioned that the salinity level was suddenly jumped when the leachate valve was open twenty days after the school break which is shown briefly in Figure 3-8. The reduction of salinity level with time for the samples are shown in Appendix B. The leaching procedure was finished when salinity reached to a desired level. After the leaching process, the leached sample was extruded from the ring as shown in Figure 3-10. From the extruded leached soil at least three samples were taken from top, middle and bottom part of the leached sample to verify the uniformity of the leaching process. So far, the samples those were taken out after leaching process and tested later, were found uniform salinity throughout the leached sample. 


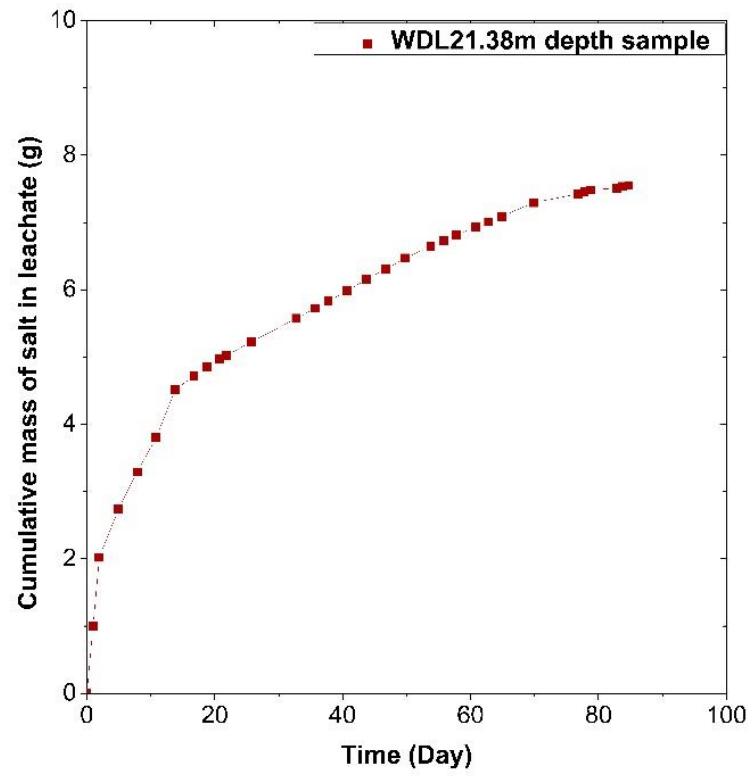

Figure 3-9 Typical cumulative mass of salt collection in leachate over time

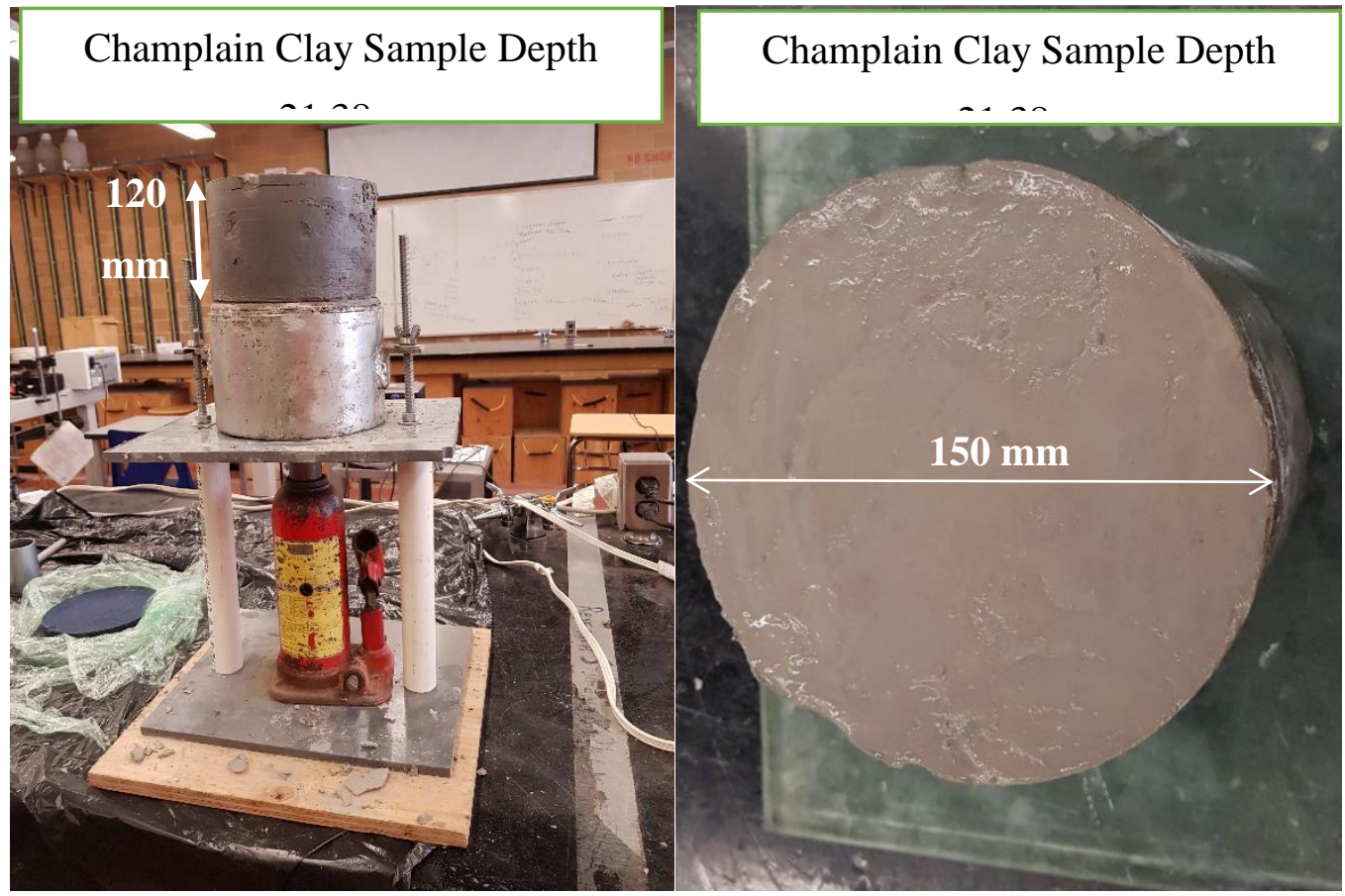

Figure 3-10 Extruding the leached sample (right) and leached sample after being extruded (left) 


\subsubsection{Index properties of leached soil}

\subsubsection{Grain size distribution}

In this study, a sieve analysis was performed on the leached soil sample at $22.20 \mathrm{~m}$ depth according to ASTM D6913 and ASTM D422. Another sieve analysis on the native soil of the same depth was also conducted to compare with the leached one. From the sieve analysis results, a modest change in the grain size distribution was observed when the soil was leached as shown in Figure 3-11.

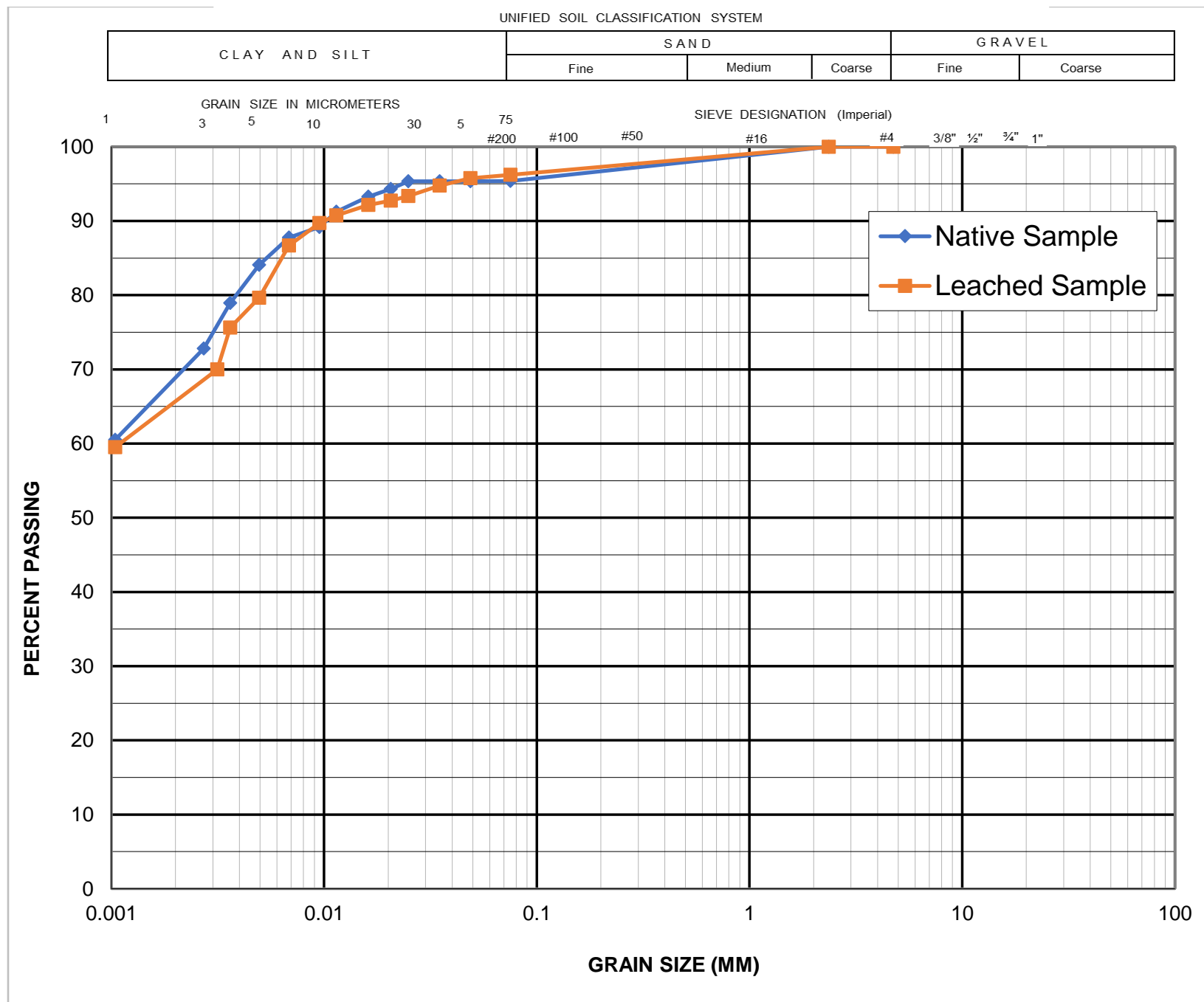

Figure 3-11 Typical grain size distribution comparing leached and native samples 


\subsubsection{Atterberg limits}

Atterberg limits were also conducted on leached samples. The test results were compared with the native soil at the same depth as shown in Table 3-2 and Figure 3-12. Test results shows that there was a slight reduction in liquid limit when the sample was leached. A similar trend was also reported by Bjerrum (1954) and Ismael (1993). Liquidity index for the soil samples were obtained to be close to 1. Similar results were reported by other researchers (Quigley, et al., 1985; Taha 2010). Liquidity index was slightly higher for the leached soil which made the soil more sensitive (Scott, 2003).

Table 3-2 Atterberg limits test results for leached and native soil samples in this study

\begin{tabular}{|c|c|c|c|c|c|c|c|}
\hline $\begin{array}{c}\text { Soil } \\
\text { Type }\end{array}$ & $\begin{array}{c}\text { Depth } \\
\text { of } \\
\text { sample } \\
\text { Native }\end{array}$ & $\begin{array}{c}\text { Salinity } \\
\text { level } \\
(\mathrm{g} / \mathrm{L})\end{array}$ & $\begin{array}{c}\text { Water } \\
\text { content, } \\
W c(\%)\end{array}$ & $\begin{array}{c}\text { Liquid } \\
\text { limit, LL } \\
(\%)\end{array}$ & $\begin{array}{c}\text { Plastic Limit, } \\
\text { PL }(\%)\end{array}$ & $\begin{array}{c}\text { Plasticity } \\
\text { Index, PI } \\
(\%)\end{array}$ & $\begin{array}{c}\text { Liquidity } \\
\text { Index, } I_{L}\end{array}$ \\
\hline Native & 21.38 & 9.5 & 80 & 82 & 34 & 48 & 0.96 \\
\hline Native & 22.20 & 9.85 & 77 & 80 & 28 & 52 & 0.94 \\
\hline Leached & 23.17 & 2.75 & 71 & 72 & 30 & 42 & 0.98 \\
\hline Leached & 21.38 & 1.03 & 72 & 65 & 32 & 33 & 1.21 \\
\hline Leached & 22.20 & 0.35 & 78 & 74 & 36 & 38 & 1.10 \\
\hline
\end{tabular}




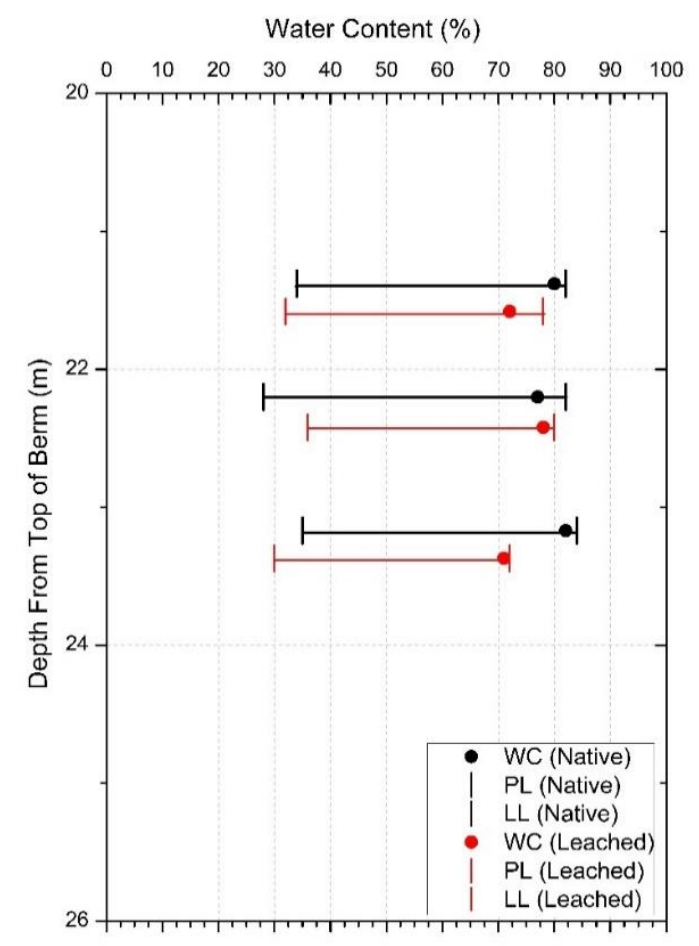

Figure 3-12 Atterberg limits for native and leached soil samples

\subsubsection{Chemical properties}

\subsubsection{Energy-dispersive $X$-ray spectroscopy (EDS) analysis}

Energy-dispersive X-ray spectroscopy (EDS) is a kind of analytical technique that helps to do chemical characterization or elemental analysis of a sample. EDS analysis was conducted on both native and leached soil. For the native soil (salinity of $9.5 \mathrm{~g} / \mathrm{L}$ ), the analysis showed that mostly sodium and chloride mineral (i.e. sodium chloride) dominant salt is present in the soil sample as shown Figure 4-14. But when the soil sample leaches (salinity of $1.03 \mathrm{~g} / \mathrm{L}$ ) both sodium and chloride minerals went down to a considerable amount as shown in Figure 4-15. 


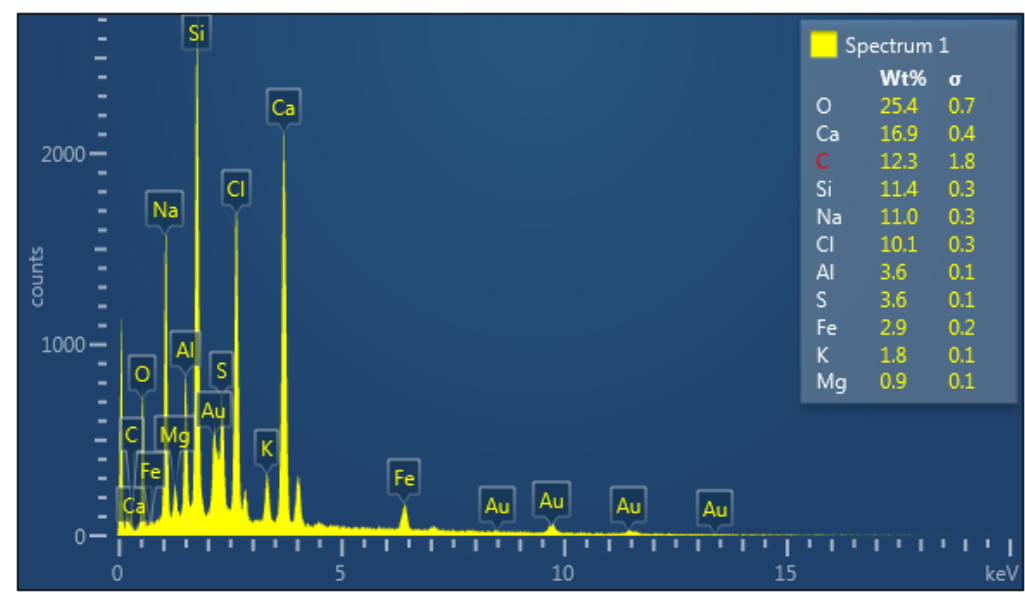

Figure 3-13 Elemental composition as determined by the EDS for the unleached soil at $23.17 \mathrm{~m}$ depth (salinity level $9.75 \mathrm{~g} / \mathrm{L}$ )

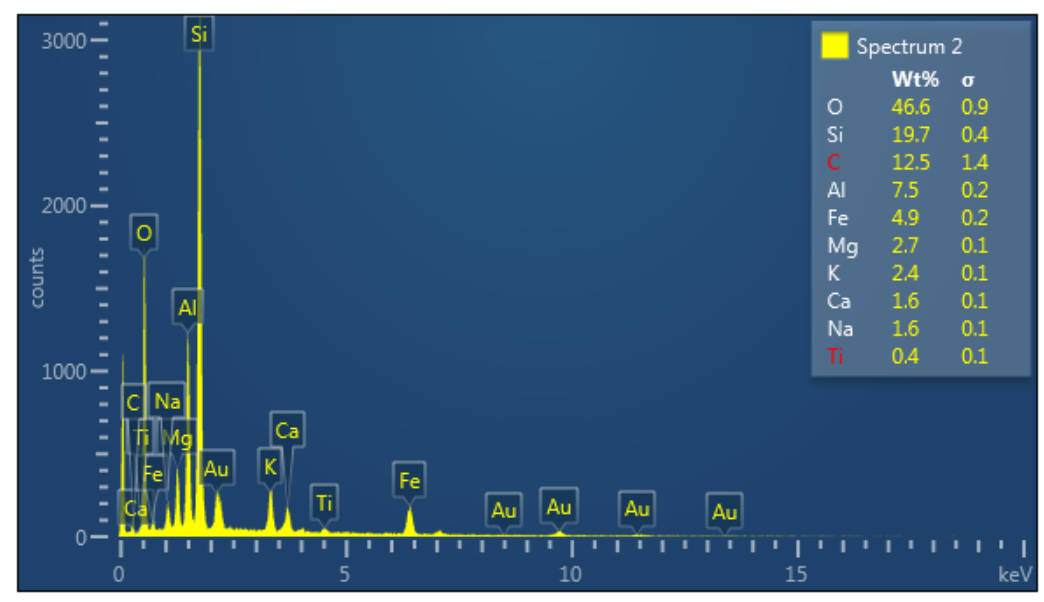

Figure 3-14 Elemental composition as determined by the EDS for the leached soil at $23.17 \mathrm{~m}$ depth (salinity level $1.03 \mathrm{~g} / \mathrm{L}$ )

\subsubsection{2 pH determination}

The $\mathrm{pH}$ value was obtained for both native and leached soil samples by using a $\mathrm{pH}$ meter in the laboratory. From the results, it seems that the native soil sample was slightly basic as pH value ranged from 8.10 to 8.27 . As the sample was leached, the test results showed that the $\mathrm{pH}$ value increased which indicates that the soil sample becomes more basic as the $\mathrm{pH}$ values ranged from 8.4 to 8.9. From this increasing tendency, it can be said that the lower the salt level of the soil sample, the higher the $\mathrm{pH}$ value will be. The reason might be the decrease of chloride mineral during the leaching process which was also observed in the EDS analysis. When chloride mixed 
with water, a weak acid is formed. As chloride mineral diminishes during the leaching process makes the in the soil sample more alkaline, resulting an increase in the $\mathrm{pH}$ value.

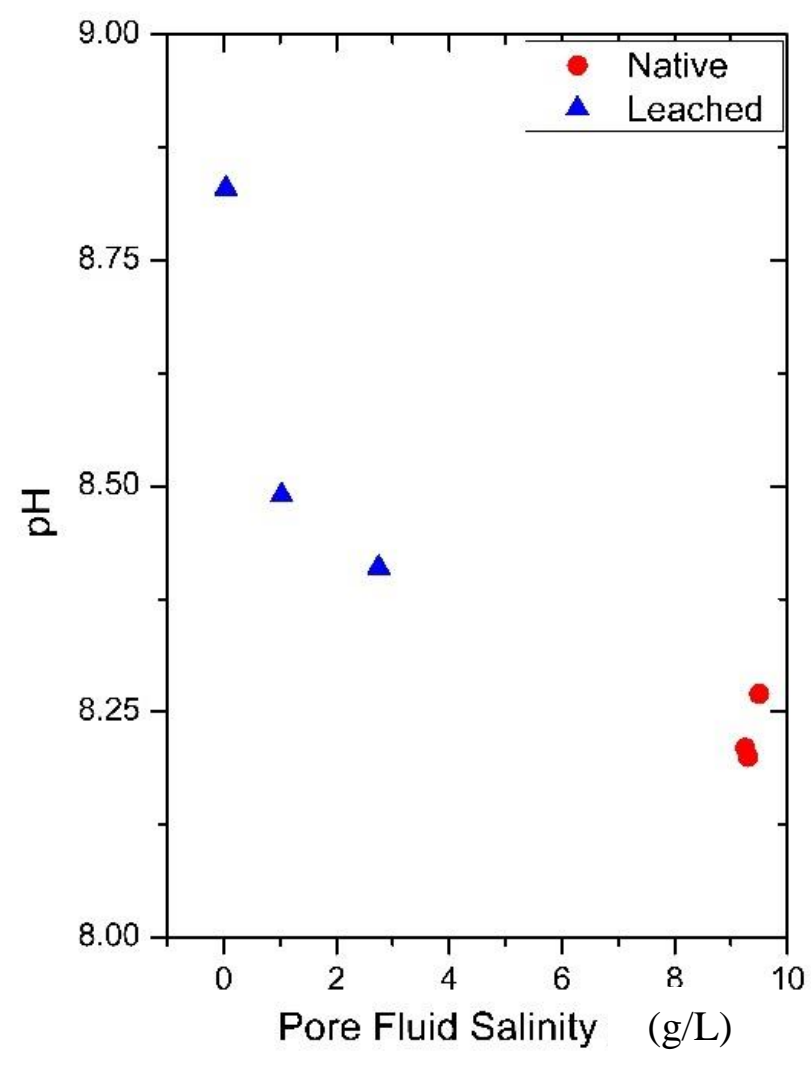

Figure 3-15 pH level at different salinity of soil

\subsection{Shear Strength Properties Obtained from Test by Triaxial Testing}

Triaxial test is one of the most versatile and widely accepted geotechnical tests that helps in determining shear strength and stiffness of soil and rock for geotechnical design. Primary parameters that can be obtained from this test include the angle of shearing resistance $\phi^{\prime}$, cohesion 
$\mathrm{c}^{\prime}$, and undrained shear strength $\mathrm{c}_{\mathrm{u}}$, although other parameters such as the shear stiffness $\mathrm{G}$, and permeability k may also be determined.

Soil responses are different in different testing methods and their engineering applications are also different. Three types of triaxial compression tests can be conducted in the laboratory:

$>$ Unconsolidated undrained test (UU)

$>$ Consolidated isotropic undrained test (CIU)

$>$ Consolidated drained test (CD)

For this research, only CIU tests were conducted.

\subsubsection{Sample Preparation for the triaxial testing}

\subsubsection{Preparing sample from native soil}

Before placing into the triaxial cell, the undisturbed native clay specimen that extruded from Shelby tube or cut from the block samples was trimmed to appropriate shape and size (38 $\mathrm{mm}$ diameter and $76 \mathrm{~mm}$ height) as shown in Figure 4-16.

\subsubsection{Preparing sample from DMM sample}

According to the FHWA manual, wet mixing method was used to prepare cement-treated clay samples. Ordinary Portland cement was used in the mix at a dosage of $50 \mathrm{~kg} / \mathrm{m}^{3}$ per treated soil wet volume. First, according to 1:1 water to cement mix ratio, slurry was prepared with two spatulas by hand for about two minutes. Clumps and aggregates were crushed to assure a homogeneous mixture. The final state of the slurry should be liquid and runny with no visible clumps or sludge. Second, due to small mixing quantity, a small mixture was used to mix the clay sample with slurry as shown in Figure 3-17. Sample was transferred to the mixer's metal bowl and placed under the mixer's mechanical mixing hook. Clay sample was mixed for about ten minutes. Third, after mixing, DMM samples were compacted as shown in Figure 3-17, are described as follows:

i. $\quad$ Each mold ( $38 \mathrm{~mm}$ dia and $76 \mathrm{~mm}$ height) is filled with approximately three lifts

ii. Each layer is compacted by hitting the mould 10 times against the floor

iii. Repeat Step 1 and Step 2 until the tube is filled to the top 
iv. Seal the mold with the plastic wrap and cure the sample in a curing tank

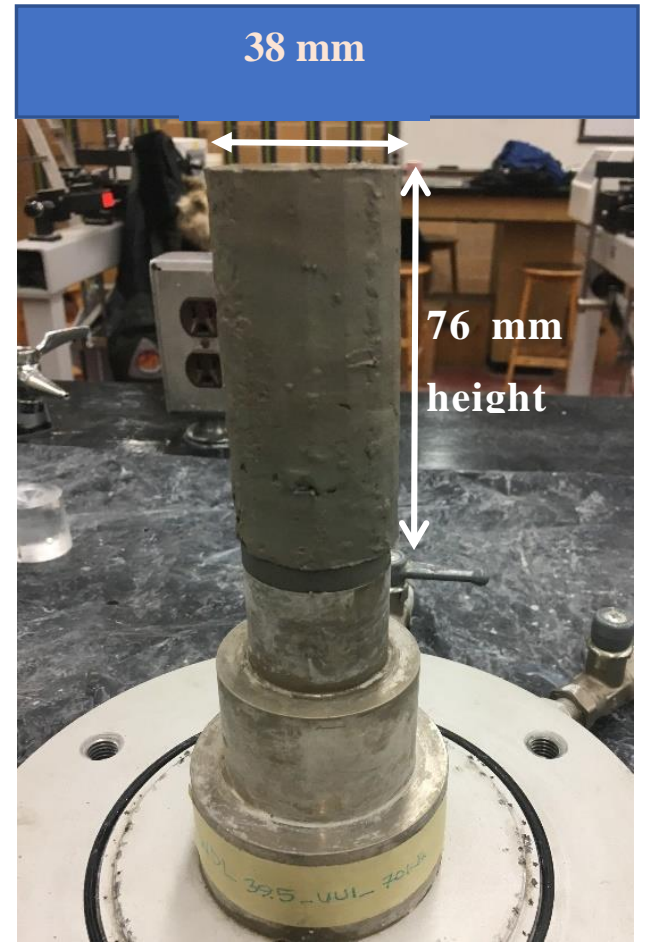

Figure 3-16 Native clay specimen before placing to a triaxial cell

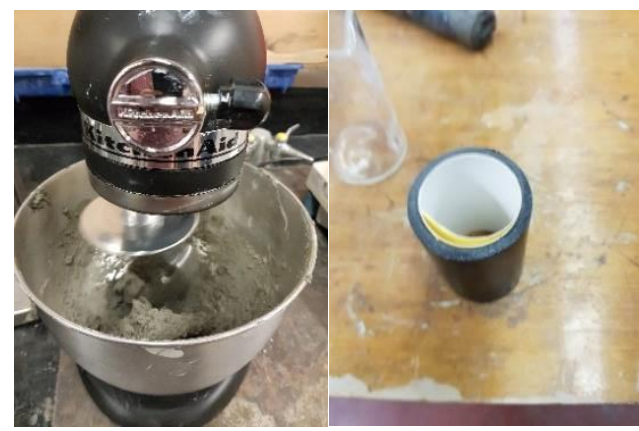

$\mathrm{a}$

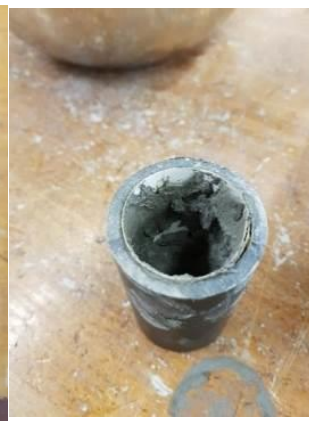

b

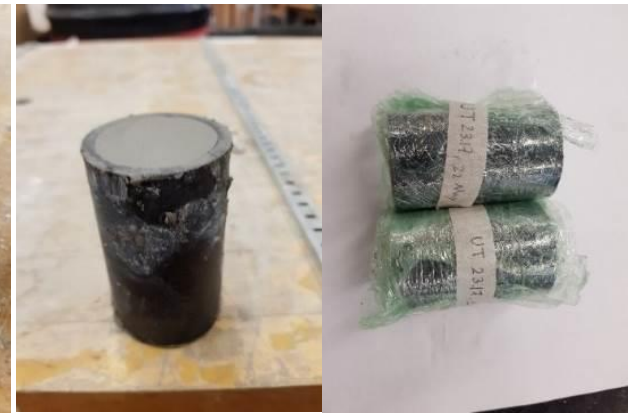

d e

Figure 3-17 DMM sample preparation- a) DMM sample homogenous mixing, b) sample mold with filter paper, c) pouring DMM sample inside the mold, d) sample inside mold after being compacted, e) sealing the sample with the plastic wrap 
DMM sample prepared for triaxial testing was then extruded by using a gentle push of thumb as shown in Figure 3-18. As a small amount of grease was applied to the outside of filter paper, which eased the extruding process.

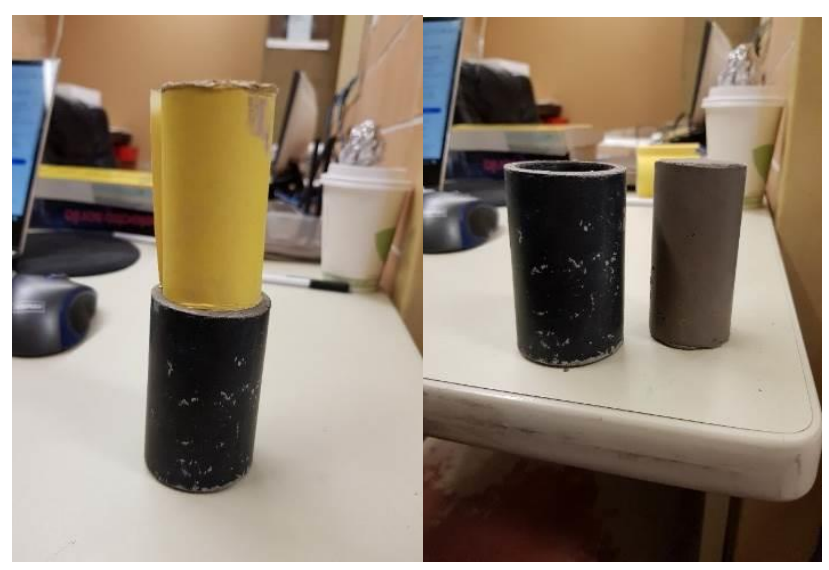

Figure 3-18 DMM triaxial sample extruding

\subsubsection{Consolidated isotropic undrained test (CIU)}

All the CIU tests were conducted according to ASTM standard D 4767-95. This test method covers the determination of strength and stress-strain relationships of saturated cohesive soil. In this method, specimens are isotopically consolidated and shared in compression without drainage at constant rate of axial compression.

\subsubsection{CIU test stages}

Triaxial test consists of four stages which are as follows:

1. Saturation

2. B-check

3. Consolidation

4. Shearing 


\subsubsection{Saturation}

The saturation process was performed to ensure that all the voids in the test specimen were filled with water and drainage lines were properly de-aired. Before saturating the sample, a partial vacuum to the specimen was applied to remove air inside the sample. Then cell and back pressures were applied to the specimen and increased proportionally so that a constant effective pressure was maintained, as shown in Figure 3-19. Since the permeability of Champlain Sea clay soil is very low, the following steps were taken to attain the full saturation. During test, a pressure increment of $50 \mathrm{kPa} / \mathrm{hr}$ was used.

$>$ de-aired water was used to fill specimen voids

$>$ back pressure was increased up to $700 \mathrm{kPa}$ to saturate the sample. A higher back pressure was needed to saturate a DMM sample than that for a native soil sample.

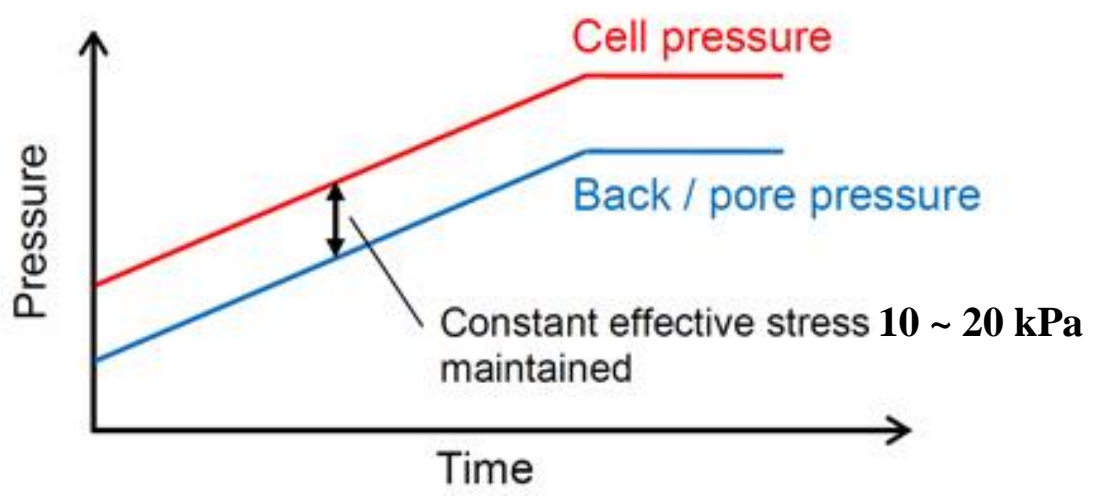

Figure 3-19 Sample saturation by increasing back pressure

\subsubsection{B-check}

After the saturation stagea short test was performed to determine Skempton's B-value for checking the degree of saturation. The Skempton's value is defined as:

$$
B=\frac{\Delta u}{\Delta \sigma}
$$

where $\Delta u$ is an increase in pore pressure, when both axial and radial stresses are increased under undrained conditions by a value $\Delta \sigma$ (in the tests $15-30 \mathrm{kPa}$ was used). In this stages $\mathrm{B}$-value was 
attained $\geq 0.92$. DMM samples were hard to saturate in comparison to the native soil since the permeability was decreased. Several methods were tried to saturate the DMM sample. The problem was solved by a large increase in back pressure which is shown briefly in Table 3-3. A typical curve showing an increase of B-value with time, as shown in Figure 3-20.

Table 3-3 Influence of back pressure and saturation time on B-value of native and DMM samples

\begin{tabular}{|c|c|c|c|c|c|}
\hline \multicolumn{3}{|c|}{ Native Sample } & \multicolumn{3}{|c|}{$\begin{array}{c}\text { DMM Sample } \\
\left(50 \mathrm{~kg} / \mathrm{m}^{3} \text { dosage sample } 7 \text { days cured sample }\right. \\
\text { before placing in the triaxial cell) }\end{array}$} \\
\hline $\begin{array}{c}\text { Back } \\
\text { Pressure } \\
\text { (kPa) }\end{array}$ & $\begin{array}{l}\text { Saturation } \\
\text { time (Day) }\end{array}$ & B - Value & $\begin{array}{c}\text { Back Pressure } \\
(\mathrm{kPa})\end{array}$ & $\begin{array}{l}\text { Saturation } \\
\text { time (Day) }\end{array}$ & B - Value \\
\hline 400 & 2 & 0.96 & 400 & 2 & 0.38 \\
\hline 600 & 1.5 & 0.98 & 600 & 1.5 & 0.49 \\
\hline- & - & - & 700 & 2 & 0.58 \\
\hline- & - & - & 700 & 4 & 0.79 \\
\hline- & - & - & 700 & 7 & 0.95 \\
\hline
\end{tabular}

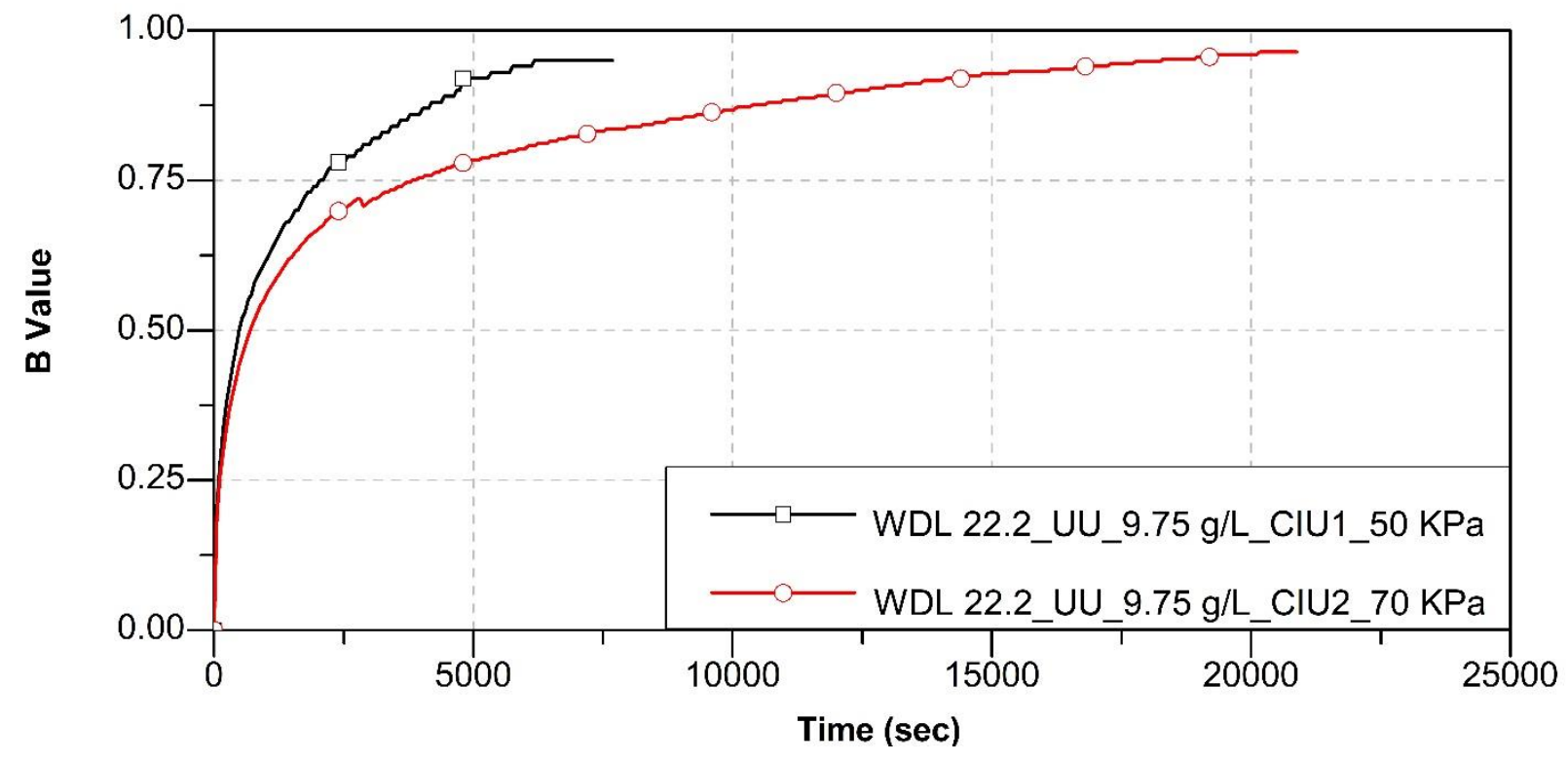

Figure 3-20 Typical curve of increase in B-value with time 


\subsubsection{Consolidation}

The consolidation stage was used to bring the specimen to the required effective stress for shearing. The stage was performed by increasing the cell pressure while maintaining the constant back pressure. This stage was continued until the volume change $\Delta V$ of the specimen was no longer significant and the excess pore pressure was dissipated at least $95 \%$. In this study only over consolidation tests were conducted. For this reason, a consolidation pressure between 50 to 120 $\mathrm{kPa}$ was considered in the tests. Figure 3-21 shows typical behaviour of pore water pressure during consolidation.

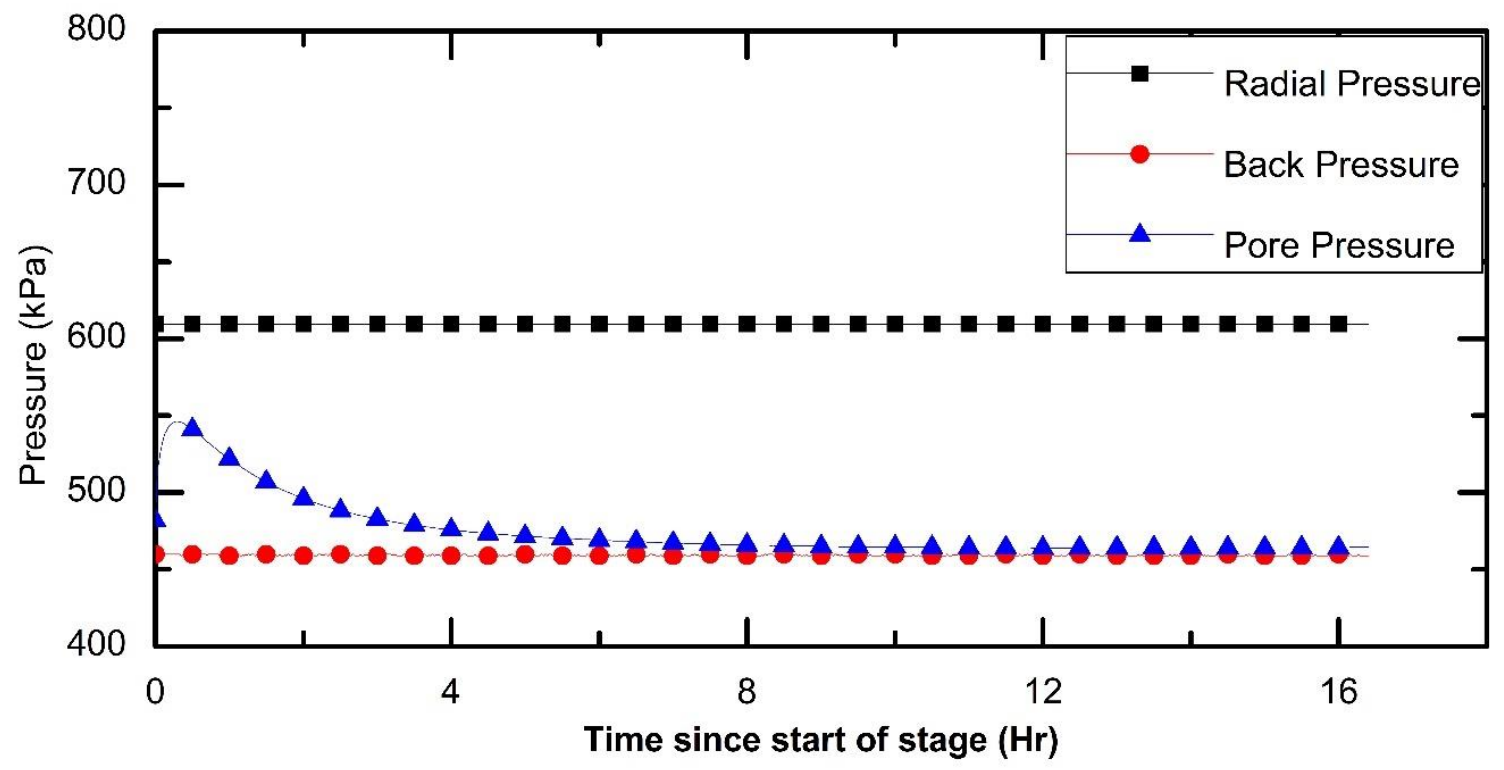

Figure 3-21 Typical graph showing consolidation stage with time

\subsubsection{Shearing}

After the consolidation stage, this stage was conducted by shearing the soil by applying an axial strain $\varepsilon_{a}$ to the test specimen at a constant rate. Since the permeability of sample is low, lower strain rate is recommended by the researchers (Lade, 2016). All the tests were conducted at rate of $1 \% / \mathrm{hr}$. The stage was continued until a specified failure criterion has been reached, which may include identification of the peak deviator stress or peak effective principal stress ratio, and a specific value of axial strain $\varepsilon_{a}=20 \%$ being reached. 
The pore pressure responses from native samples were much different from those of the DMM samples. For the undisturbed soil samples, the pore pressure and back pressure were increasing with time, while for the DMM sample the pore pressure and back pressure were increasing at the beginning but after a while they started to decrease as the native samples were slightly overconsolidated, and the DMM samples were highly over-consolidated (although the consolidation pressure was same but the pre-consolidation pressure for the DMM sample were much higher than the native samples) which is illustrated in Figures 3-23.

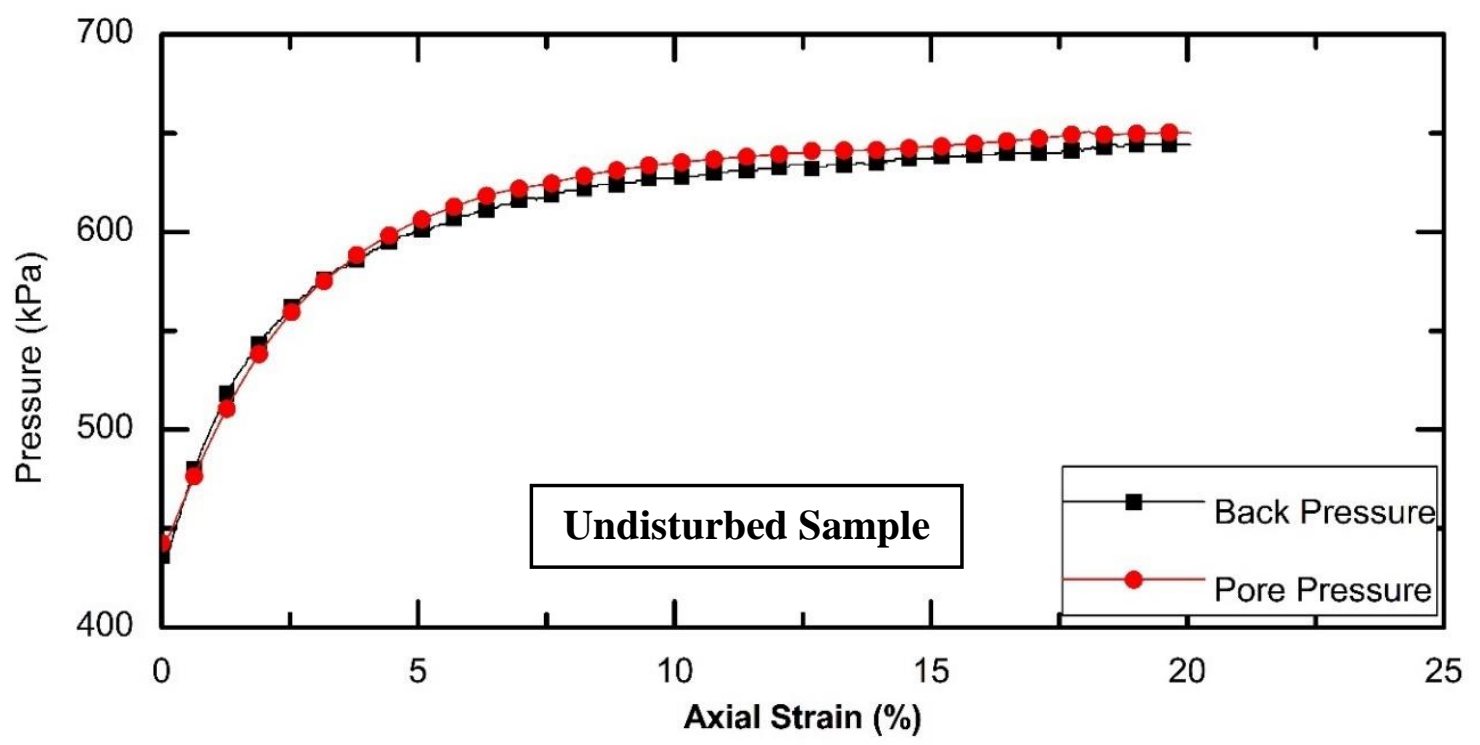

Figure 3-22 Typical undisturbed soil specimen back and pore pressure response during shearing 


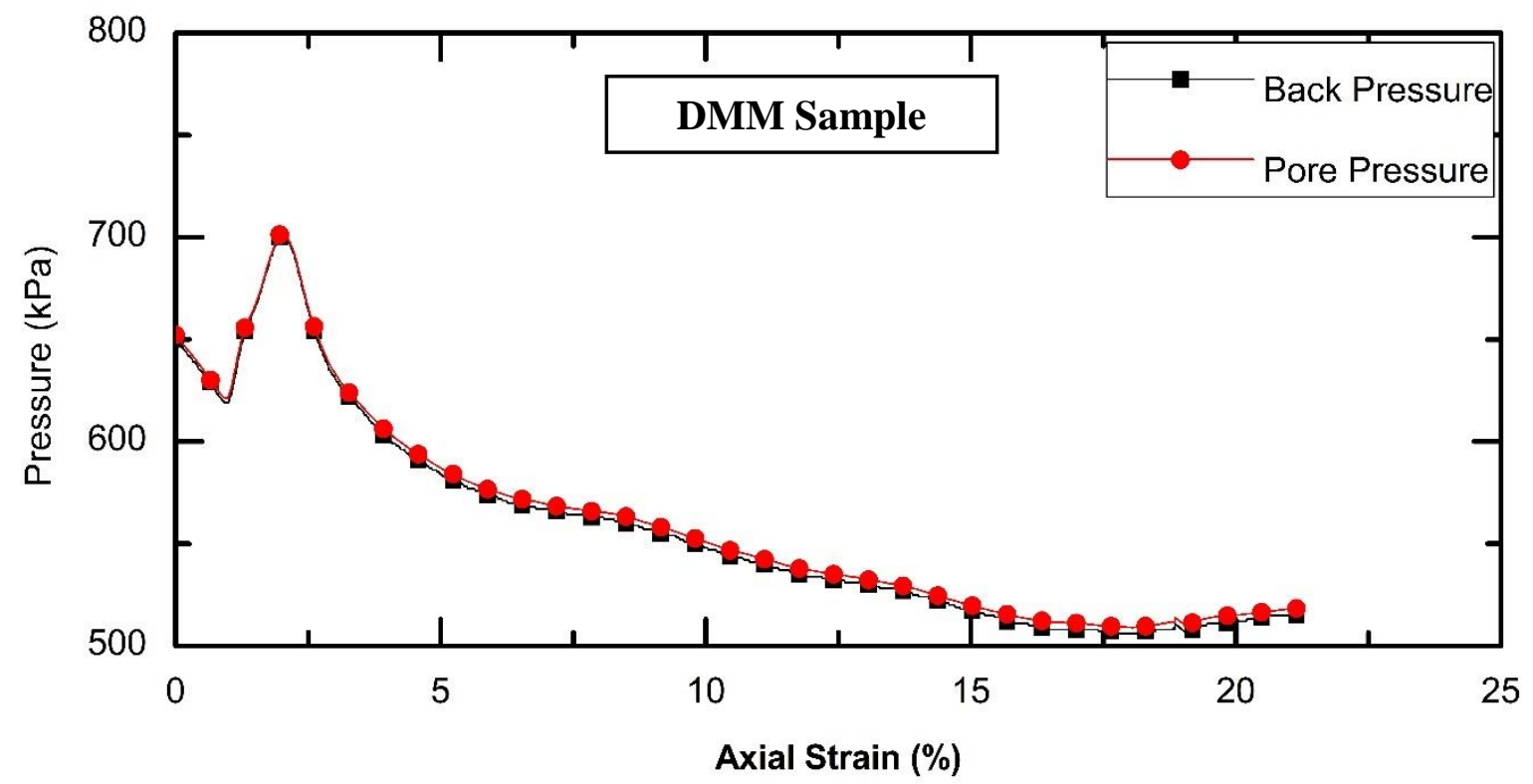

Figure 3-23 Typical DMM specimen back and pore pressure response during shearing

\subsubsection{Data Processing of Triaxial tests}

\subsubsection{Evaluation of cohesion ( $\left.C^{\prime}\right)$ and angle of internal friction ( $\left.\Phi^{\prime}\right)$}

To obtain the shear strength parameters stress-paths are often used by the researchers. When the stresses acting at a point experience changes, these changes may be suitably represented on a plot of shear stress against normal stress which is known as stress path. As stress paths only are plotted then the axes of the diagram are particular values (commonly referred to as $q$ and $p$ ) of the shear stress $\tau$ and normal stress $\sigma$.

$$
\begin{aligned}
& \mathrm{q}=\tau_{\max }=\frac{\sigma_{1}-\sigma_{3}}{2} \\
& \mathrm{p}=\text { mean normal stress }=\frac{\sigma_{1}+\sigma_{3}}{2}
\end{aligned}
$$

Equation 3-1

Equation 3-2

The shear strength values is taken from the residual strength, which shows as a line tangential to the stress-path at the end of the test, as $\varphi^{\prime} c^{\prime}$ shown in Figure 3-24. In case the cohesion received 
from this is lower than zero, a zero cohesion is assumed to obtain the friction angle value of shear strength.

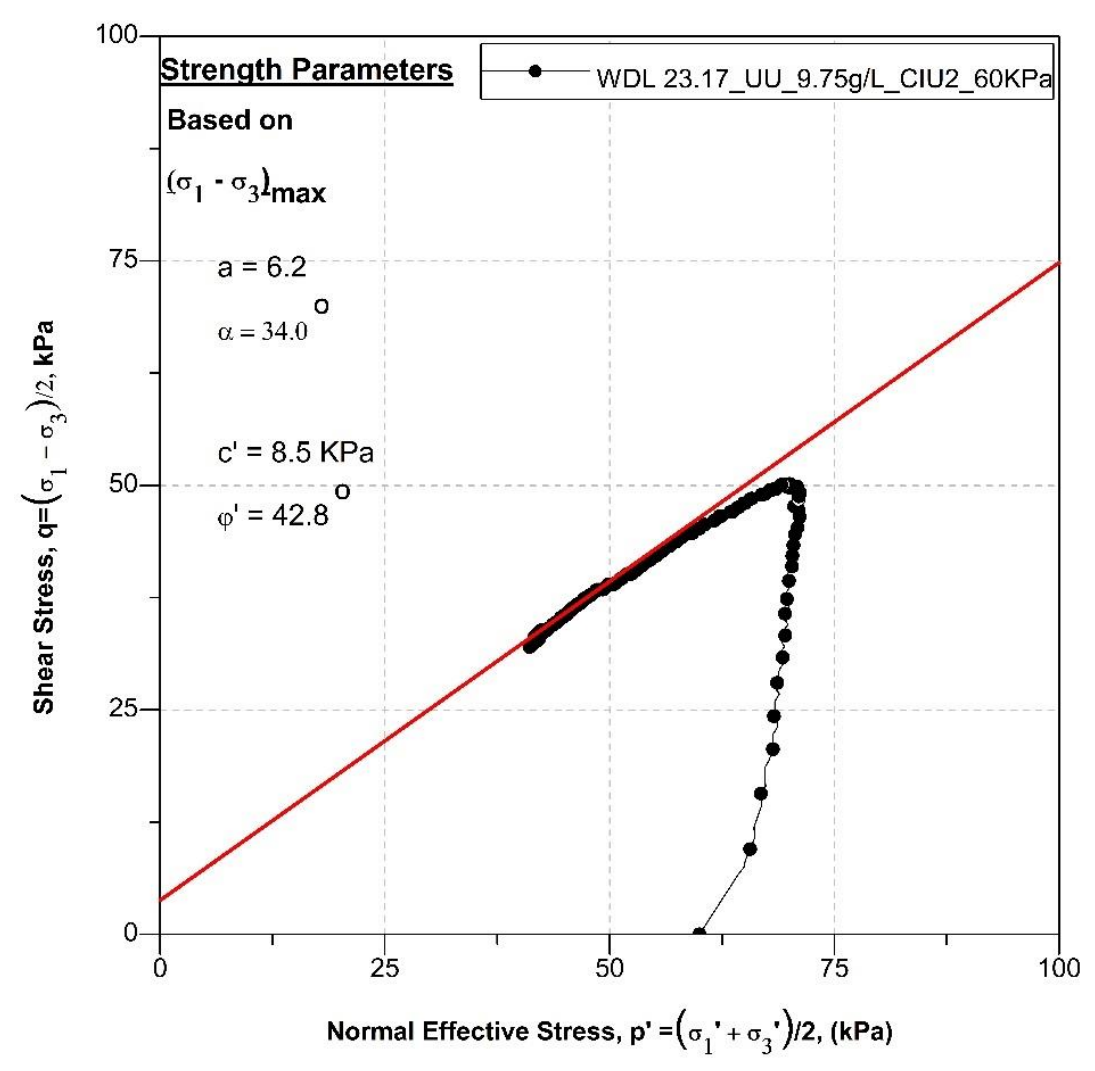

Figure 3-24 Typical p-q curve of CIU test

\subsubsection{Evaluation of modulus of soil sample, $E$}

Soil modulus, E, is an elastic soil parameter and a measure of soil stiffness. In order to evaluate modulus of elasticity, E the stress-strain diagram was drawn. The modulus of DMM was determined from the slope of stress-strain curve at stress levels of $1 / 3^{\text {rd }}$ to $2 / 3^{\text {rd }}$ of maximum deviator stress as shown in Figure 3-25. 


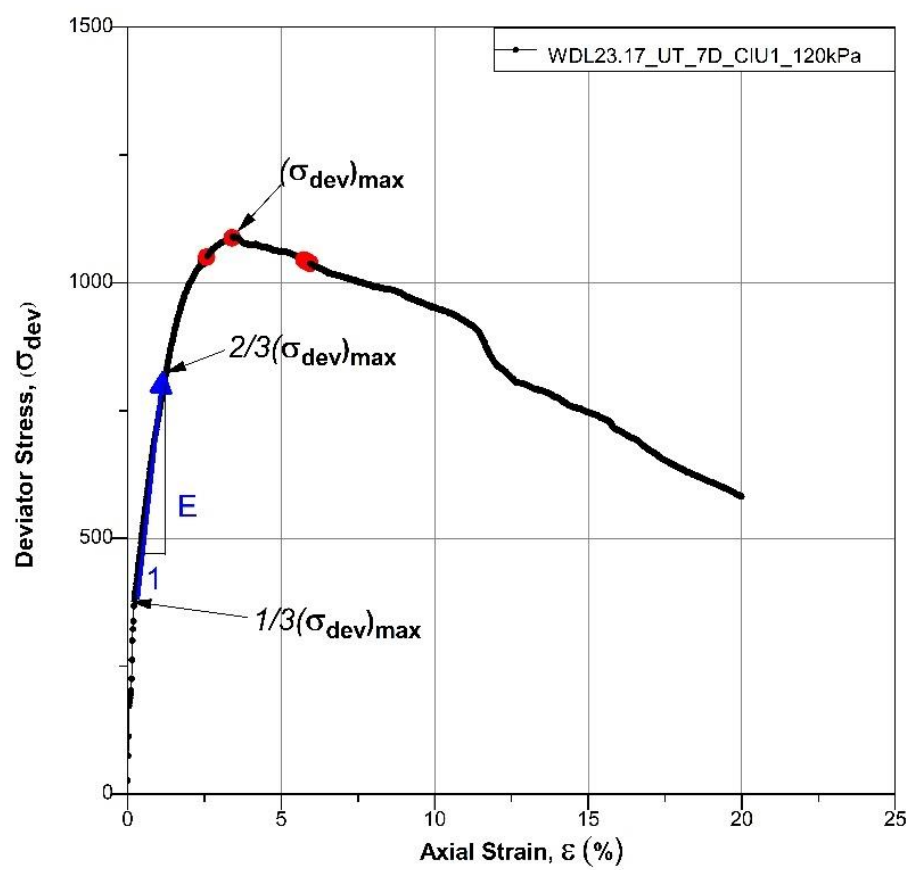

Figure 3-25 Typical stress-strain curve for sample of CIU test

\subsection{Compressibility Tests by CRS Testing Machine}

Two methods are well known to the researchers to determine the consolidation behaviour of soil: consolidation by incremental loading odometer test, and constant rate of strain (CRS). CRS test offer several benefits over incremental oedometer tests for the following reasons (Adam, 2011):

i) Significant reduction of time and manpower in both test procedure and data analysis;

ii) Computer controlled automated test procedure

iii) Continuous compression data can be obtained that improves data accuracy

iv) Secondary compression cannot able to affect the result

v) Automated data analysis

vi) Saturation can be easily obtained by application of back pressure

vii) Hydraulic conductivity can also be obtained, and the pore water pressure can be measured. 
The test specimen was trimmed into a stainless-steel ring. DMM sample was inserted to the ring and then it is cured for desired period of curing time. Wire sow was used in order to remove the extra part adhered to the specimen and to obtain flat surfaces at both top and bottom. Two filter papers were placed both top and bottom of the flat surfaces of the specimen and a pore stone was placed on top of the top filter paper to keep the drainage open. The specimen was mounted and then the cell was assembled, and piston was locked. After that, the load cell and the piston were lowered in order to contact the specimen. A target stress of $6.13 \mathrm{kPa}$ was applied slowly eliminate the gap in between specimen, piston, porous stone and the cell bottom. After reaching the target stress (i.e. $6.13 \mathrm{kPa}$ ), the cell was filled with water. Then the back pressure of $350 \mathrm{kPa}$ was applied to saturate the sample. Once the saturation done, the consolidation stage was initiated. Test specimen was drained from the top, and excess porewater pressure was measures from the bottom. During the consolidation stage, for all samples, the strain rate that applied are shown in the Table 3-4 according to the ASTM D4186. For all samples, stress levels for loading and unloading stage were limited to $2394 \mathrm{kPa}$ and $96 \mathrm{kPa}$ respectively as shown in the Table 3-4.

Table 3-4 CRS test loading stages with strain rate

\begin{tabular}{|c|c|c|}
\hline Loading stages & Strain Rate $(\% / \mathrm{hr})$ & Limit Stress $(\mathrm{kPa})$ \\
\hline 1 - Loading & 1 & 2394 \\
\hline 2- Unloading & 0.25 & 96 \\
\hline
\end{tabular}

\subsubsection{Data processing of CRS test}

All the data were processed according to the guidelines and equations provided by ASTMD4186.

Total axial stress, $\sigma_{a, n}(\mathrm{kPa})$ at any given time can be calculated as follows:

$$
\sigma_{a, n}=\frac{f_{a, n}}{A} \times 10000 \quad \text { Equation 3-3 }
$$

Where, $f_{a, n}=$ net applied force to specimen, $\mathrm{kN}$

$\mathrm{A}=$ specimen area, $\mathrm{cm}^{2}$ 
The average axial effective stress, $\sigma_{a, n}^{\prime}(\mathrm{kPa})$ at any given time can be calculated as follows:

$$
\sigma_{a, n}^{\prime}=\left(\sigma_{a, n}-\frac{2}{3} \Delta u_{m, n}\right) \quad \text { Equation 3-4 }
$$

Void ratio, $e_{n}$, at any given time or line data can be calculates by using the following equation:

$$
e_{n}=\frac{H_{n}-H_{S}}{H_{s}} \quad \text { Equation 3-5 }
$$

The base excess pore pressure, $\Delta u_{m, n}(\mathrm{kPa})$ at any given time or line data can be calculates by using the following equation:

$$
\Delta u_{m, n}=u_{m, n}-\sigma_{c, n} \quad \text { Equation 3-6 }
$$

Where, $u_{m, n}=$ base pressure, $\mathrm{kPa}$

$\sigma_{c, n}=$ chamber pressure, $\mathrm{kPa}$

Hydraulic conductivity, $\mathrm{k}$ can be for given line of data by using the following equation:

$$
k_{n}=\frac{\varepsilon_{n} H_{n} H_{o} \gamma_{w}}{2 \Delta u_{m, n}} \times \frac{1}{10000} \quad \text { Equation 3-7 }
$$

Where, $k_{n}=$ hydraulic conductivity, $\mathrm{m} / \mathrm{s}$

$\gamma_{w}=$ unit weight of water, at $20^{\circ} \mathrm{C}, \mathrm{kN} / \mathrm{m}^{3}$

$\varepsilon_{n}=$ strain rate at time $\mathrm{n}$

$H_{o}=$ Specimen initial height

$H_{n}=$ Specimen height at time $\mathrm{n}$ 
Volume compressibility, $m_{v, n}\left(m^{2} / \mathrm{kN}\right)$, can be for given time or line of data by using the following equation,

$$
m_{v, n}=\frac{\epsilon_{n+1}-\epsilon_{n-1}}{\sigma^{\prime} a, n+1}-\sigma_{a, n-1}^{\prime} \times \frac{1}{100} \quad \text { Equation 3-8 }
$$

Coefficient of consolidation, $c_{v, n}\left(\mathrm{~m}^{2} / \mathrm{s}\right)$, can be for given time or line of data by using the following equation,

$$
c_{v, n}=\frac{k_{n}}{m_{v, n} \gamma_{w}} \quad \text { Equation 3-9 }
$$

\subsubsection{Determination of compression and recompression index}

Compression index was obtained from the test results which were plotted in terms of the void ratio versus the logarithm of effective stress. The slope of the virgin compression curve is the compression index, $c_{c}$. For the sensitive clay is known for the $\mathrm{S}$-shaped compression curve (shown in Figure 2-4) which comprises of three sections: over-consolidated loading (Zone I), soil collapse after $P_{c}$ ' (Zone II), and normally consolidated loading after the soil has regained strength (Zone III). In this report although three zones are shown in this report, but Zone II is used for the report to emphasise $c_{c}$ as other researchers do. The recompression index, $c_{r}$, is the slope of the recompression part of the e versus $\log \mathrm{p}^{\prime}$.

\subsubsection{Determination of pre-consolidation pressure}

To determine the pre-consolidation pressure from e- $\log \mathrm{p}^{\prime}$ curve, there are many different methods available. In this research, in determining pre-consolidation pressure, method proposed by Pacheco Silva (1970) was used which is also recommended by the other researchers (Clementino, 2005). According to Pacheco Silva, pre-consolidation pressure can be obtained graphically which is briefly explained below using the figure 3-26.

(i) first, a horizontal line $(\mathrm{A}-\mathrm{B})$ passing through the initial void ratio $\left(e_{0}\right)$ of the specimen is needed to be sketched; 
(ii) second, the straight-line portion of virgin compression curve (C-D) is extended until it intercepts line A-B. In case of sensitive clay, the straight-line portion of Zone II (mentioned in section 3.5.1.1) of virgin the compression curve is considered as C-D line;

(iii) third, from the point of intersection of lines, A-B C-D, a vertical line is needed to be drawn until it intercepts the $\mathrm{e}-\log \mathrm{p}^{\prime}$ curve (Point E);

(iv) forth, a horizontal line from Point E required to be drawn until it intercepts line C-D (Point F); and

(iv) last, the pre-consolidation pressure $\left(p^{\prime}{ }_{c}\right)$ can be obtained from the stress value in the horizontal axis associated with Point $\mathrm{F}$

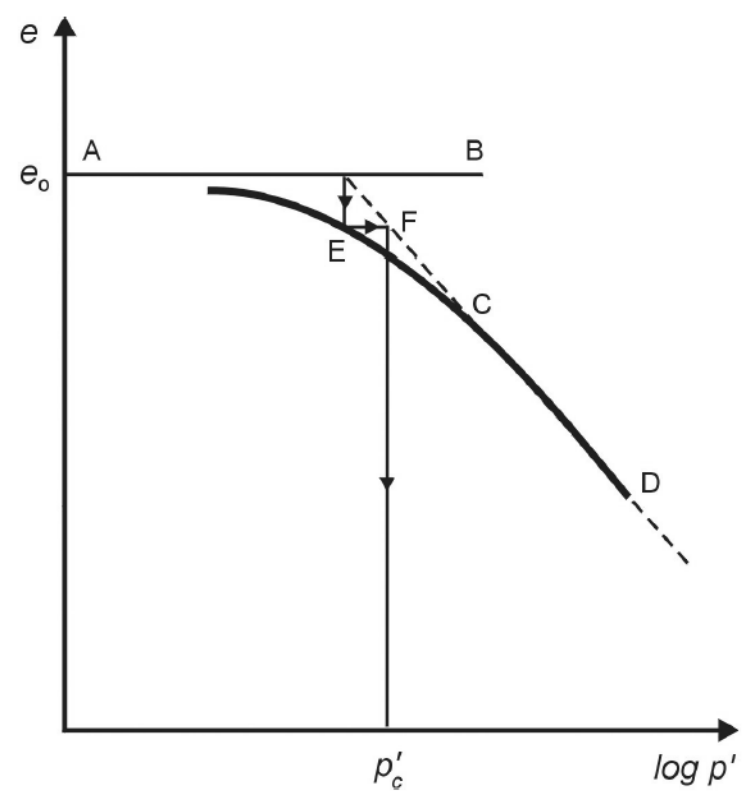

Figure 3-26 Determination of pre-consolidation stress using the Pacheco Silva construction (Clementino, 2005) 


\section{RESULTS AND ANALYSIS OF TEST}

\subsection{CRS Tests Result and Analysis}

\subsubsection{Leaching impact on the undisturbed Champlain Sea clay}

A total of four CRS tests were conducted on undisturbed leached samples and native samples. Native sample was obtained from $21.38 \mathrm{~m}$ depth at salinity level $9.5 \mathrm{~g} / \mathrm{L}$. And, three leached samples were obtained by leaching native samples (extracted from 20 to $25 \mathrm{~m}$ depth) in the laboratory with distilled water to the salinity level of $1.43,0.55$, and $0.35 \mathrm{~g} / \mathrm{L}$. Test results are shown in Figure 4-1 through Figure 4-6.

The $\varepsilon-\log \sigma^{\prime}$ compression curves of undisturbed unleached and leached soil samples are shown in Figure 4-1. For the undisturbed native soil sample, a maximum vertical strain of $40 \%$ was obtained at a vertical stress of $2.39 \mathrm{MPa}$ at the end of loading. On the other hand, maximum vertical strain for the leached samples was obtained $42.5 \%, 45 \% \& 47 \%$ at salinity level of $1.43,0.55 \& 0.35 \mathrm{~g} / \mathrm{L}$ respectively. From test results a, trend of increasing compressibility was observed when salinity declines.

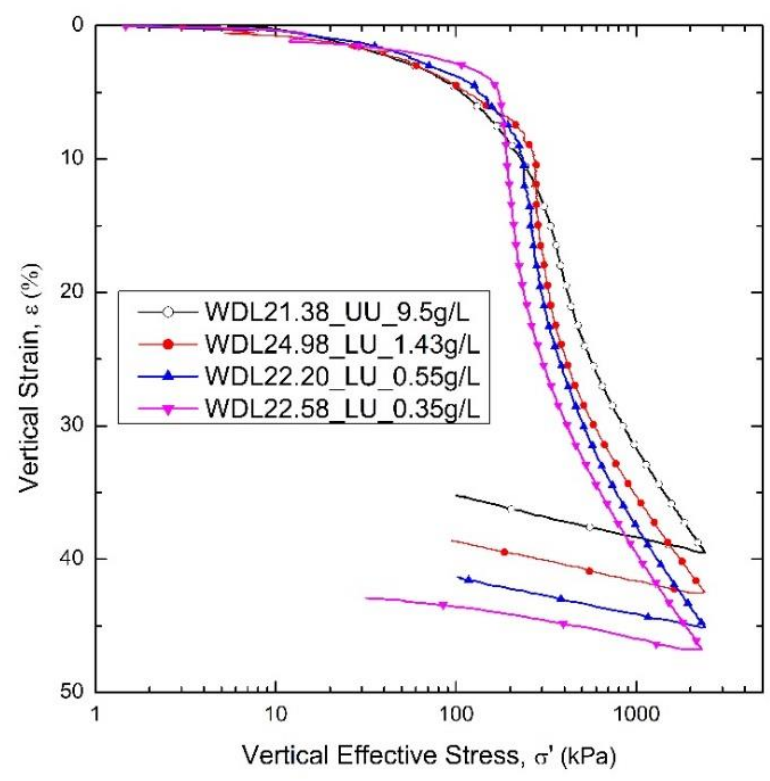

Figure 4-1 $\varepsilon-\log \sigma^{\prime}$ compression curve for untreated leached and unleached samples 
The e- $\log \sigma^{\prime}$ plots of undisturbed unleached and leached soil samples are shown in Figure 4-2. From the e-log $\sigma^{\prime}$ curves for the native soil sample, the pre-consolidation pressure was determined as $210 \mathrm{kPa}$. Whereas, for the leached samples pre-consolidation pressure was recorded 180 and $140 \mathrm{kPa}$ at salinity level 0.55 and $0.35 \mathrm{~g} / \mathrm{L}$ respectively. The pre-consolidation pressure decreased for the leached soil may due to the partial removal of salt and cementation accompanying with it. To calculate settlements in soil, compression index $\left(C_{c}\right)$ and recompression index $\left(C_{r}\right)$ are the most commonly used parameters. In comparison to undisturbed native sample the coefficient of compressibility $\left(C_{c}\right)$ of leached sample has increases by more than $20 \%$, and coefficient of recompression index $\left(C_{r}\right)$ has increased by $50 \%$. This agrees with results of kim \& Do (2009) and Ahmad (2018) which is also included in Figure 4-3. Furthermore, leached samples exhibit increased initial void ratios which might be due to decrease in volume of solids (as salt was leached away from the soil) and errors occurred during sample preparation. The initial void ratio $e_{o}$ of the unleached sample was 1.99. And, for the leached samples initial void ratio was obtained 2.03, 2.10 and 2.13 at salinity level $1.43,0.55$ and $0.35 \mathrm{~g} / \mathrm{L}$ respectively.

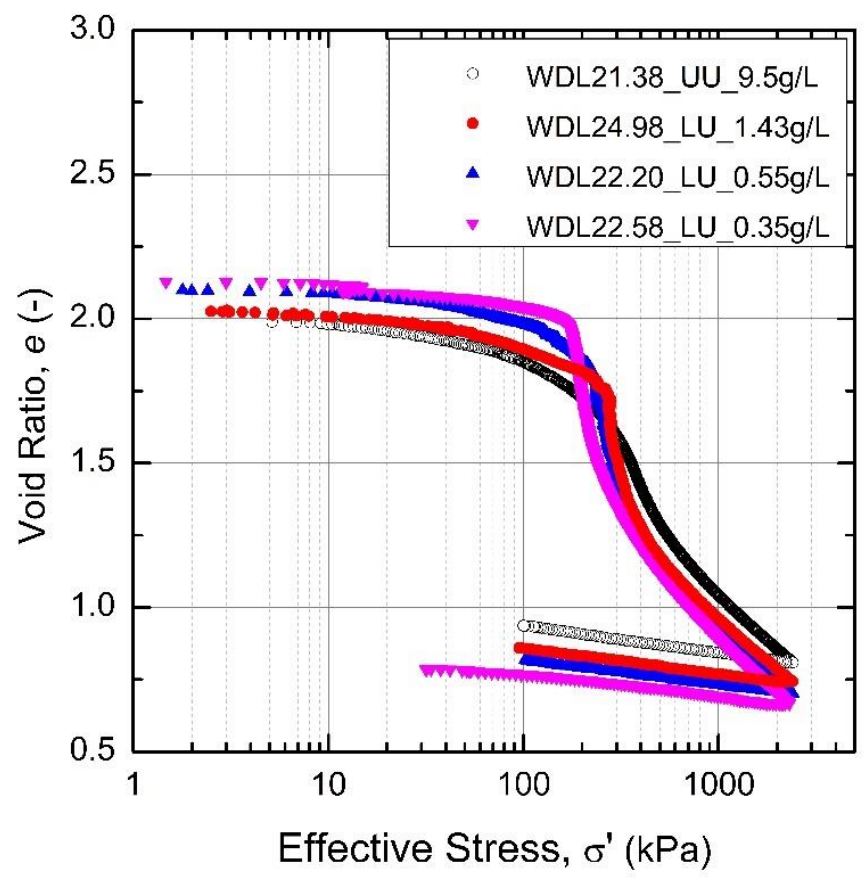

Figure 4-2 e- $\log \sigma^{\prime}$ plot comparing untreated leached and unleached samples 
When natural Champlain Sea clay soil was leached to salinity level of $0.35 \mathrm{~g} / \mathrm{L}, 34 \%$ increased in the relative compressibility $\left(\frac{C_{c}}{1+e_{o}}\right)$ was obtained in the CRS testing machine. Similar results were reported for salt-bearing clay soil in Doha by Ismael (1993).

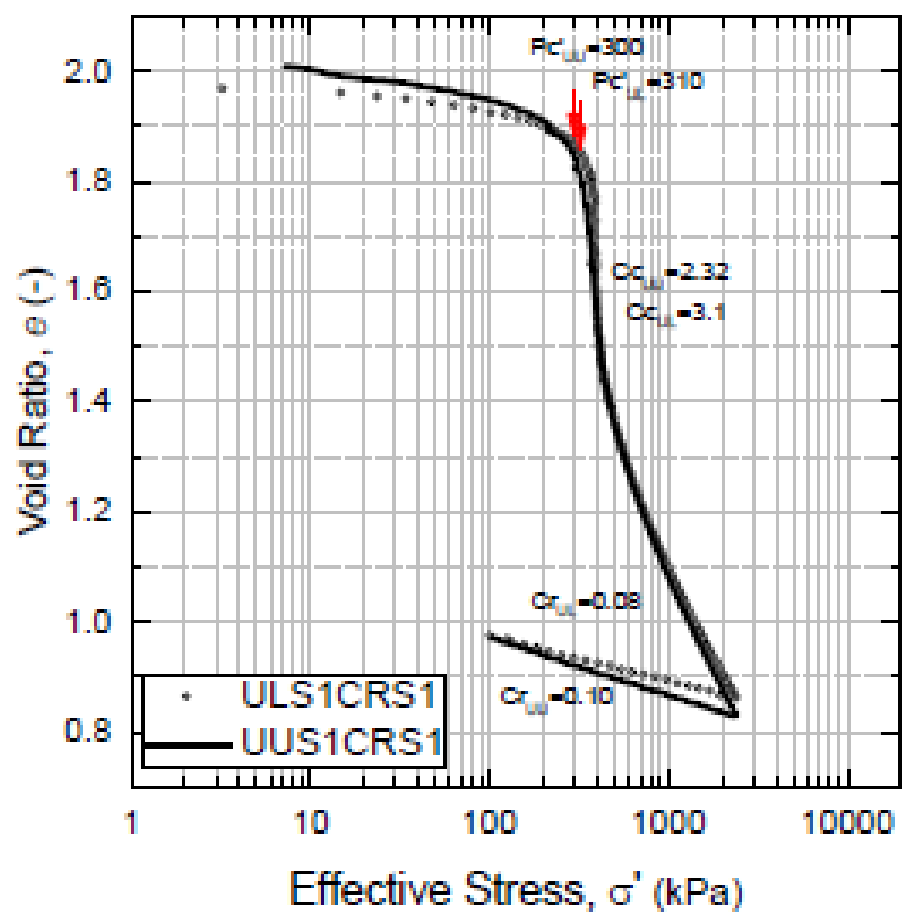

Figure 4-3 Influence of leaching on e-log p curve of undisturbed Sample at 38m depth of Champlain Sea clay (Ahmad, 2018).

The increase in the compression index and the recompression index may be attributed to a weakening of the inter-particle forces due to leaching (Kim \& Do, 1972). The compressibility parameters from the consolidation tests are shown in Table 4-1.

The coefficient of volume change, $M_{v}$, for both leached and unleached samples were plotted against the effective stress. For both leached and unleached samples, $M_{v}$ decreases with an increase of effective stress until the pre-consolidation pressure, $p^{\prime}{ }_{c}$ was reached. After reaching the $p^{\prime}{ }_{c}, M_{v}$ 
increased until $200 \mathrm{kPa}$ for leached and $300 \mathrm{kPa}$ for unleached samples and proceeds to decrease for the remainder of the test duration. A minor difference was observed when comparing leached and unleached samples. For unleached samples, $M_{v}$ was within the range of $1 \times 10^{-3}$ to $2 \times 10^{-5} / \mathrm{kPa}$. Whereas, for the leached samples, $M_{v}$ was within the range of $1.5 \times 10^{-3}$ to $2 \times 10^{-5} / \mathrm{kPa}$ shown in Figure 4-4.

Table 4-1 Summary of consolidation parameters for native and leached samples

\begin{tabular}{|c|c|c|c|c|c|c|c|c|c|}
\hline $\begin{array}{l}\text { Type of } \\
\text { Sample }^{1}\end{array}$ & $\begin{array}{c}\text { Sample } \\
\text { Designation }\end{array}$ & $\begin{array}{c}\text { Void } \\
\text { Ratio } \\
\left(e_{0}\right)\end{array}$ & $\begin{array}{l}\text { Maximum } \\
\text { vertical } \\
\text { strain (\%) }\end{array}$ & $\begin{array}{c}\text { Pre- } \\
\text { consolidation } \\
\text { pressure, } p^{\prime}{ }_{c} \\
(\mathrm{kPa})\end{array}$ & $\begin{array}{c}\text { Comp. } \\
\text { index, } \\
c_{c-I}\end{array}$ & $\begin{array}{l}\text { Comp. } \\
\text { index, } \\
c_{c-I I}\end{array}$ & $\begin{array}{l}\text { Comp. } \\
\text { index, } \\
c_{c-I I I}\end{array}$ & $\begin{array}{l}\text { Recomp. } \\
\text { index, } c_{r}\end{array}$ & $\frac{c_{c-I I}}{1+e_{0}}$ \\
\hline UU & $\begin{array}{c}\text { WDL21.38_ } \\
\text { UU_9.50 } \\
\text { g/L }\end{array}$ & 1.99 & 40.0 & 210 & 0.13 & 2.20 & 0.62 & 0.08 & 0.736 \\
\hline $\mathrm{LU}$ & $\begin{array}{c}\text { WDL24.98_ } \\
\text { LU_1.43 } \\
\text { g/L }\end{array}$ & 2.03 & 42.5 & 205 & 0.25 & 2.51 & 0.81 & 0.09 & 0.828 \\
\hline $\mathrm{LU}$ & $\begin{array}{c}\text { WDL22.20_ } \\
\text { LU_0.55 } \\
\mathrm{g} / \mathrm{L}\end{array}$ & 2.10 & 45.0 & 180 & 0.19 & 2.70 & 0.58 & 0.12 & 0.870 \\
\hline $\mathrm{LU}$ & $\begin{array}{c}\text { WDL22.58_ } \\
\text { LU_0.35 } \\
\text { g/L }\end{array}$ & 2.13 & 47.0 & 140 & 0.12 & 3.10 & 0.70 & 0.12 & 0.990 \\
\hline
\end{tabular}

The void ratio was plotted against hydraulic conductivity (permeability), $\mathrm{k}$, for the leached and unleached samples, as shown in Figure 4-5. For both leached and unleached samples, k value (m/s) has decreased with a decrease of void ratio. The $\mathrm{k}$ value for the unleached sample ranged from $3 \times 10^{-10}$ to $7 \times 10^{-8} \mathrm{~m} / \mathrm{s}$. Whereas, for the leached samples, $\mathrm{k}$ value ranged from $6 \times 10^{-10}$ to $2 \times 10^{-7} \mathrm{~m} / \mathrm{s}$. The test results show that leached samples exhibit higher permeability than the 
unleached sample at the identical void ratio or effective stress. Similar results were also reported for salt-bearing clay soil in Doha by Ismael (1993).

The coefficients of consolidation, $C_{v}$, for both leached and unleached samples were plotted against the effective stress in Figure 4-6. For the both leached and unleached samples, $C_{v}$ was decreasing with an increase in effective stress during the over consolidated stage. Whereas, $C_{v}$ was increasing at the beginning of the normally consolidated stage and then decreases again for the remainder of the test. $C_{v}$ is related to the $M_{v}$ and k value. Therefore, a larger value of $C_{v}$ was observed for the leached sample due to higher permeability value compared to that of unleached samples. Finally, based on the laboratory test results it appears that leaching of undisturbed soil samples resulted in an increase in void ratio, compressibility, and permeability. In addition, leaching causes a reduction in pre-consolidation pressure. Similar results were also obtained by the other researchers (Kim \& Do, 1972; Ismael, 1993; Ahmad, 2018).

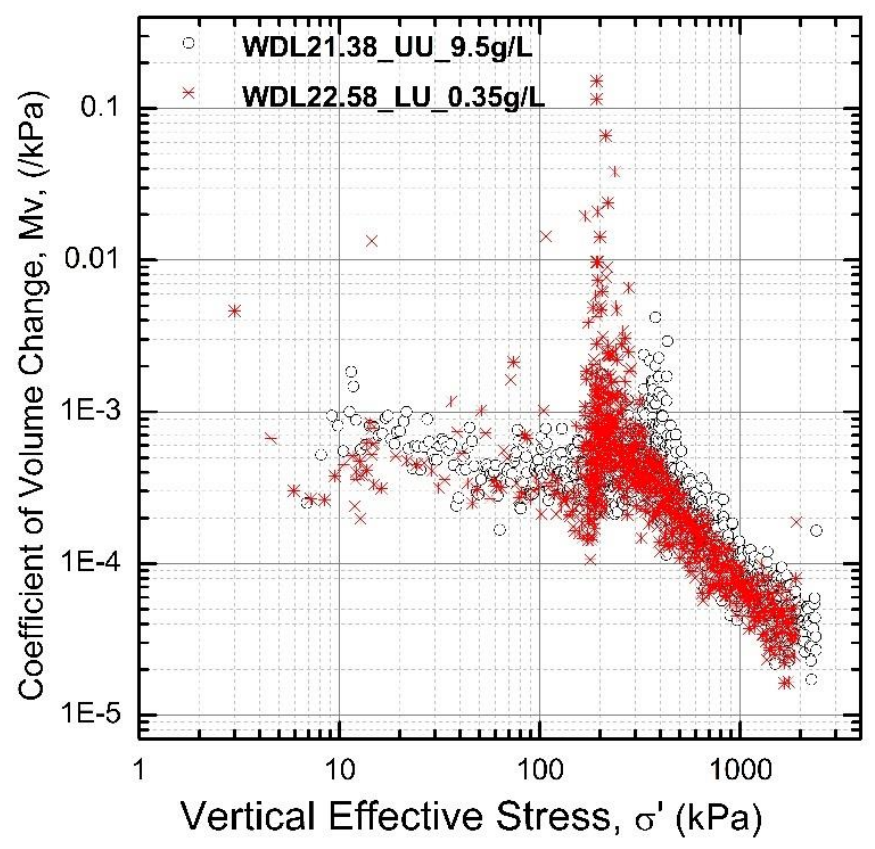

Figure 4-4 Variation of $M_{v}$ versus log effective stress of untreated leached and unleached samples 


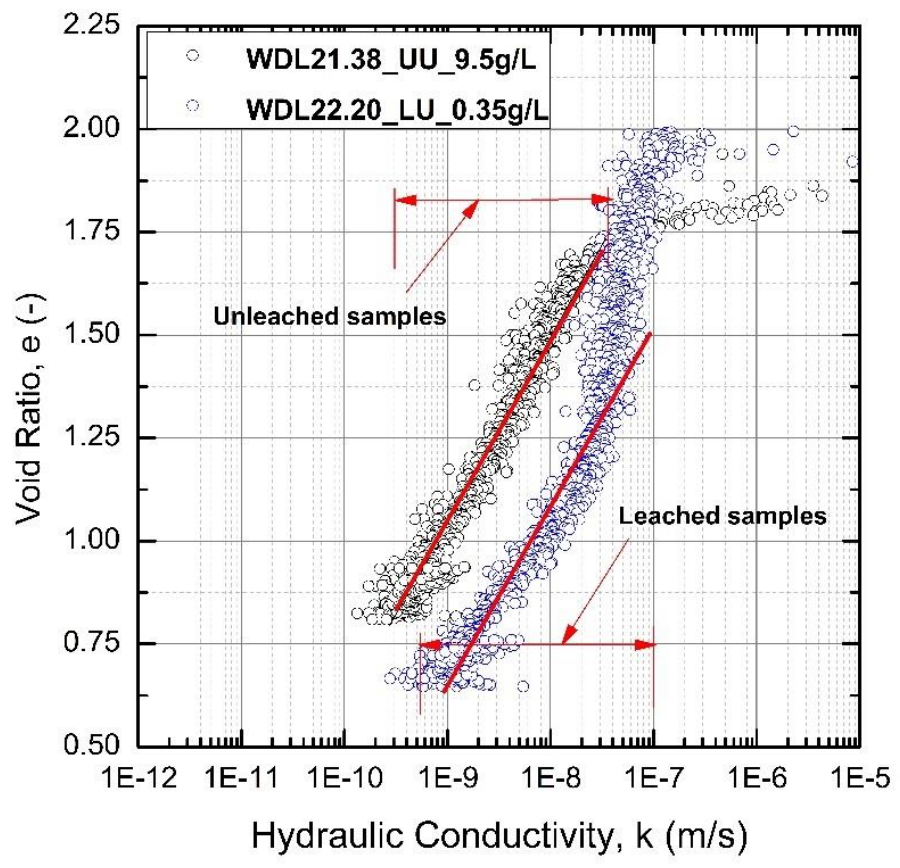

Figure 4-5 Hydraulic conductivity of untreated leached and unleached samples

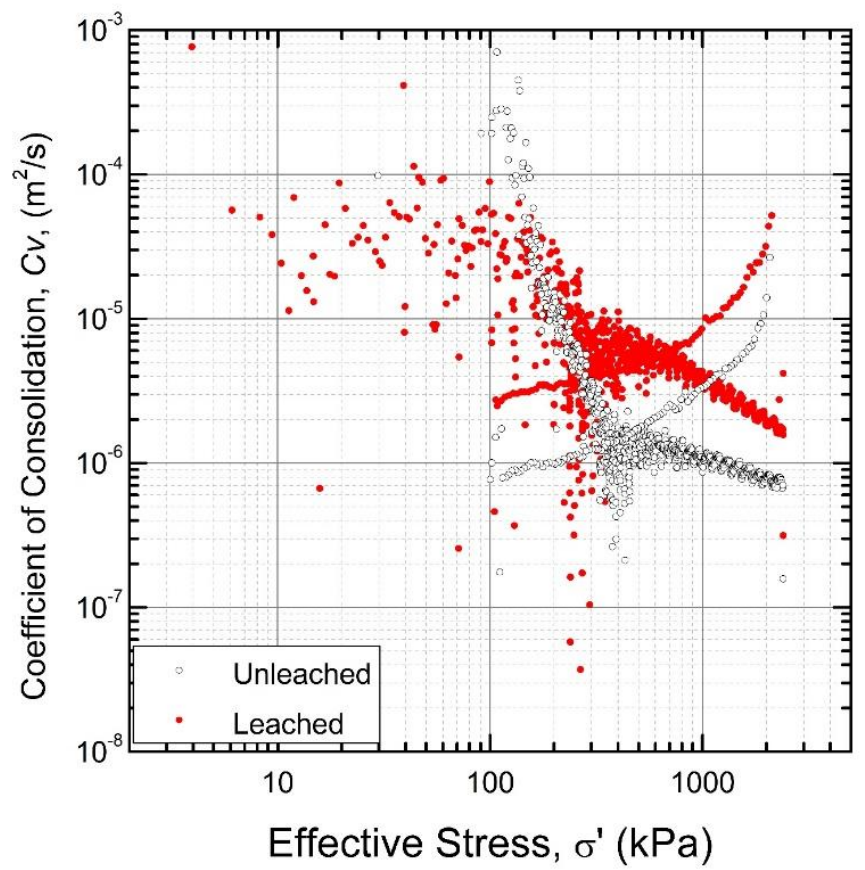

Figure 4-6 Variation of $C_{v}$ versus $\log$ effective stress of untreated leached and unleached samples 


\subsubsection{Compressibility of cement treated Champlain Sea clay}

In this study, cement-mixed soil samples were prepared at a $50 \mathrm{~kg} / \mathrm{m}^{3}$ cement dosage and were cured for 7 days. Due to the capacity restriction of the CRS machine, $50 \mathrm{~kg} / \mathrm{m}^{3}$ cement dosage samples that were cured for 7 days were considered for this study. Meaningful test results were not obtainable using present CRS machine if higher cement dosages were being used. The main objective is to investigate the impact of cement mixing on the compressibility of Champlain Sea clay. Test results are shown in the Figure 4-7 through Figure 4-11.

The $\varepsilon-\log \sigma^{\prime}$ curves of undisturbed unleached (UU) and unleached treated (UT) samples are shown in Figure 4-7. The maximum vertical strain was obtained at $40 \%$ for the undisturbed native soil at a vertical stress of $2.39 \mathrm{MPa}$ at the end of loading stage. Whereas, the maximum vertical strain was obtained to be only $10 \%$ under the same stress for the cement-treated native samples. From test results cement mixing results in a substantial reduction in the vertical strain. Consequently, the compressibility of Champlain Sea clay has significantly been improved due to cement mixing.

The e- $\log \sigma^{\prime}$ plots are shown in Figure 4-8 for undisturbed unleached (UU) and unleached treated (UT) samples. From the e-log $\sigma^{\prime}$ curves, the pre-consolidation pressure was determined as 210 $\mathrm{kPa}$ for the undisturbed natural soil sample. Whereas, for the cement-treated sample the yielding pressure was recorded as $1200 \mathrm{kPa}$. When the native clay was mixed with cement, the preconsolidation was increased due to the cementation bond induced by cement. Both the coefficient of compressibility $\left(C_{c}\right)$ and the coefficient of recompression index $\left(C_{r}\right)$ of the cement-treated sample are decreased by $60 \%$ compared to those of the native sample. Furthermore, the initial void ratio $e_{o}$ was slightly decreased due to cement mixing. An increase in the pre-consolidation pressure and a reduction in compression indices of soft clay resulting from the inclusion of cement were also reported by the other researchers (Uddin et al., 1997). A comparison of consolidation test parameters between undisturbed clay sample and cement-treated clay sample are shown in Table 4-2. A significant reduction in the compressibility of the Champlain Sea clay due to the cement mixing was also reported by Ahmad (2018) which is also included in Table 4-2. 


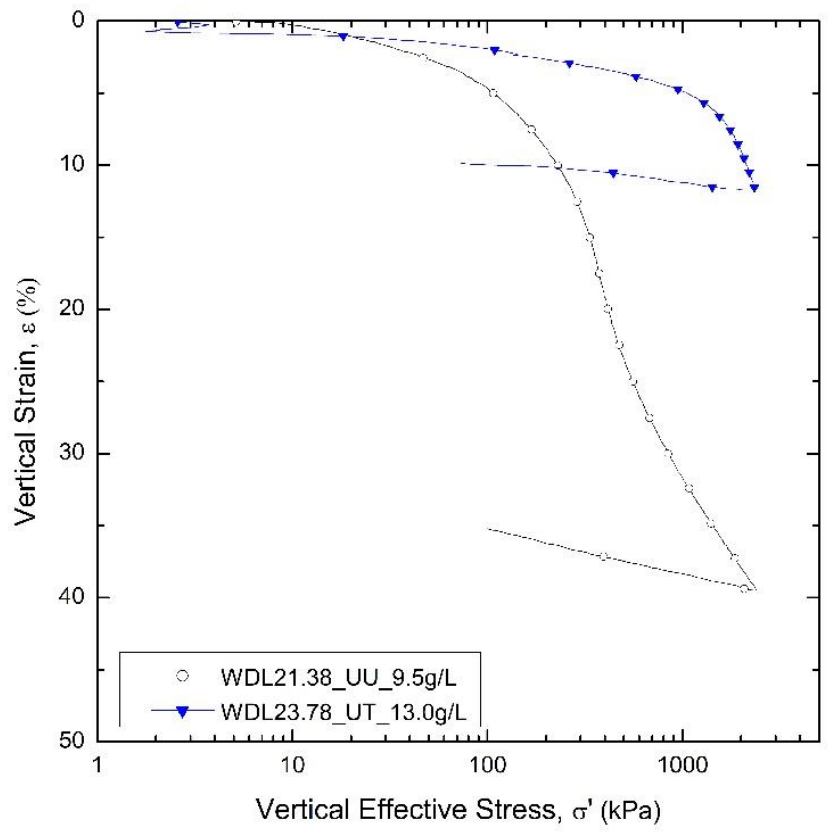

Figure 4-7 $\varepsilon-\log \sigma^{\prime}$ compression curves for undisturbed unleached and unleached treated samples

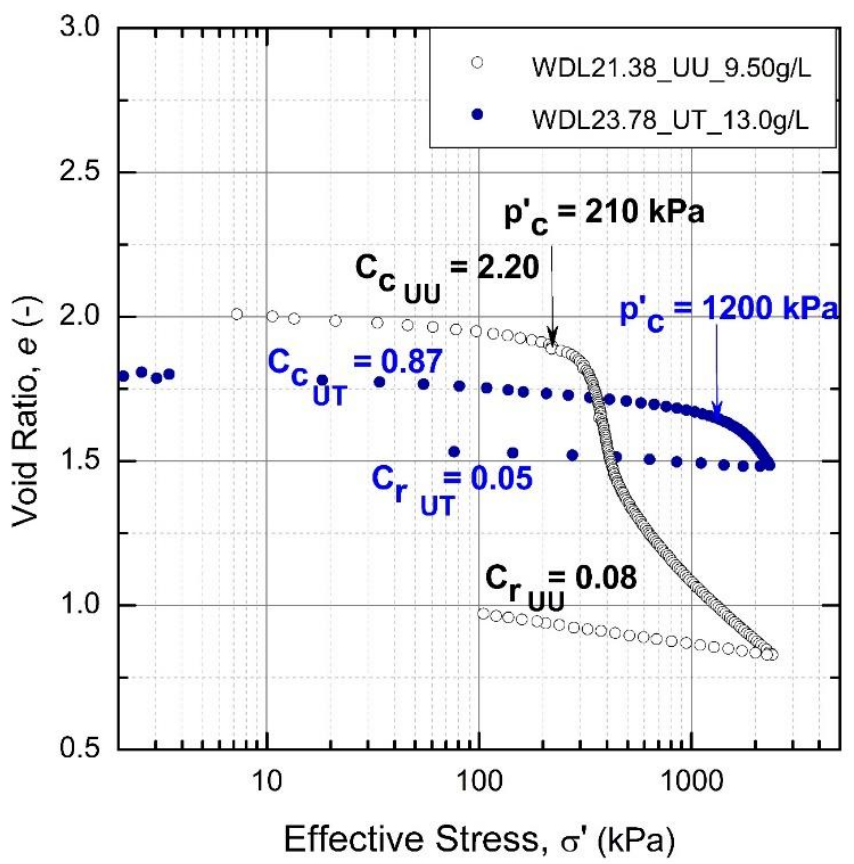

Figure 4-8 e-log $\sigma^{\prime}$ curves of undisturbed unleached and unleached treated samples 
The coefficient of volume change, $M_{v}$, for both undisturbed and cement-treated unleached samples were plotted against the effective stress in Figure 4-9. For the native sample, $M_{v}$ value decreases with an increase of effective stress until $p_{c}^{\prime}$ is reached. After reaching $p_{c}^{\prime}, M_{v}$ starts to increase until $300 \mathrm{kPa}$ for undisturbed unleached samples and then starts to decrease again until the end of the test. In contrast, for the cement-treated clay sample $M_{v}$ decreases with an increase of effective stress until the end of the test. A significant difference in $M_{v}$ was observed for cement-treated native sample compared to that of the undisturbed clay sample as shown briefly in Figure 4-9. For the undisturbed clay sample, $M_{v}$ value was within the range of $2 \times 10^{-3}$ to $1 \times 10^{-5} / \mathrm{kPa}$. Whereas, $M_{v}$ was within the range of $2 \times 10^{-4}$ to $3 \times 10^{-6} / \mathrm{kPa}$ for the cement-treated sample indicates that cement mixing decreases the compressibility of Champlain Sea clay.

The void ratio was plotted against hydraulic conductivity, $\mathrm{k}$ for the undisturbed and cement-treated unleached samples as shown in Figure 4-10. For both samples, k value decreases with a decrease of void ratio. The $\mathrm{k}$ value for the undisturbed unleached sample ranged from $3 \times 10^{-10}$ to $7 \times 10^{-8}$ $\mathrm{m} / \mathrm{s}$. In contrast, for the cement-treated native samples, $\mathrm{k}$ value ranged from $7 \times 10^{-11}$ to $2 \times 10^{-9}$ $\mathrm{m} / \mathrm{s}$. Therefore, from the test results, it seems that permeability of natural clay has decreased to a considerable amount when samples were mixed with cement. This could be due to the pozzolanic cement substance blocks the pores in the soil cement matrix. Similar findings were also reported by other researchers (Yu, et al., 1999).

The coefficient of consolidation, $C_{v}$ of the undisturbed clay sample and cement-treated sample were plotted against the effective stress as shown in Figure 4-11. $C_{v}$ is related to the coefficient of volume change and the hydraulic conductivity value. Due to a much lower coefficient of volume change, it is observed that $C_{v}$ for the cement-treated native samples is larger than that undisturbed clay samples.

Based on the laboratory test results, it can be concluded that the inclusion of cement to Champlain Sea clay results in a decrease in the compressibility and the permeability. Also, it causes a large increase in pre-consolidation pressure. Similar results were also obtained by the other researchers (Uddin et al., 1997; Yu et al., 1999; Ahmad, 2018). 
Table 4-2 Summary of consolidation parameters for native and cement-treated native samples

\begin{tabular}{|c|c|c|c|c|c|c|c|c|c|}
\hline $\begin{array}{l}\text { Type of } \\
\text { Sample }^{1}\end{array}$ & $\begin{array}{c}\text { Sample } \\
\text { Designation }\end{array}$ & $\begin{array}{c}\text { Void } \\
\text { Ratio } \\
\left(e_{0}\right)\end{array}$ & $\begin{array}{l}\text { Maximum } \\
\text { vertical } \\
\text { strain }(\%)\end{array}$ & $\begin{array}{c}\text { Pre- } \\
\text { consolidation } \\
\text { pressure, } p^{\prime}{ }_{c} \\
\text { or Yielding } \\
\text { pressure, } p^{\prime}{ }_{y} \\
(\mathrm{kPa})\end{array}$ & $\begin{array}{c}\text { Comp. } \\
\text { index, } \\
c_{c-I}\end{array}$ & $\begin{array}{c}\text { Comp. } \\
\text { index, } \\
c_{c-I I}\end{array}$ & $\begin{array}{l}\text { Comp. } \\
\text { index, } \\
c_{C-I I I}\end{array}$ & $\begin{array}{l}\text { Recomp. } \\
\text { index, } c_{r}\end{array}$ & $\frac{c_{c}}{1+e_{0}}$ \\
\hline UU & $\begin{array}{c}\text { WDL21.38_ } \\
\text { UU_9.50 } \\
\text { g/L }\end{array}$ & 1.99 & 40.0 & 210 & 0.13 & 2.20 & 0.62 & 0.08 & 0.736 \\
\hline $\mathrm{UU}^{2}$ & $\begin{array}{c}\text { WDL38.8_ } \\
\text { UU_19.81 } \\
\mathrm{g} / \mathrm{L}\end{array}$ & 1.99 & - & 310 & - & 2.32 & 0.73 & 0.10 & 0.776 \\
\hline UT & $\begin{array}{c}\text { WDL23.78_ } \\
\text { UT_13.00 } \\
\text { g/L }\end{array}$ & 1.81 & 10.0 & 1200 & 0.06 & 0.87 & N/A & 0.05 & 0.310 \\
\hline $\mathrm{UT}^{2}$ & $\begin{array}{c}\text { WDL38.80_ } \\
\text { UT_19.81 } \\
\text { g/L }\end{array}$ & 1.67 & - & 1050 & - & 0.52 & N/A & 0.04 & 0.195 \\
\hline \multicolumn{10}{|c|}{ Note 1: UU-Undisturbed Unleached, UT-Unleached Treated } \\
\hline
\end{tabular}




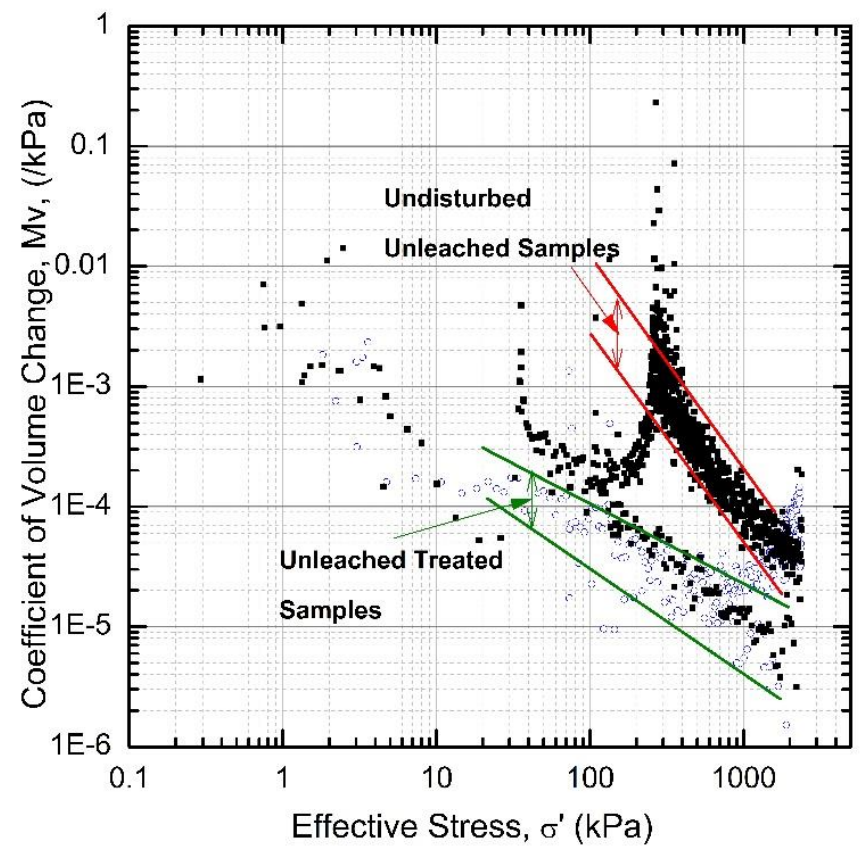

Figure 4-9 Variation of $M_{v}$ versus effective stress of undisturbed unleached and unleached treated samples

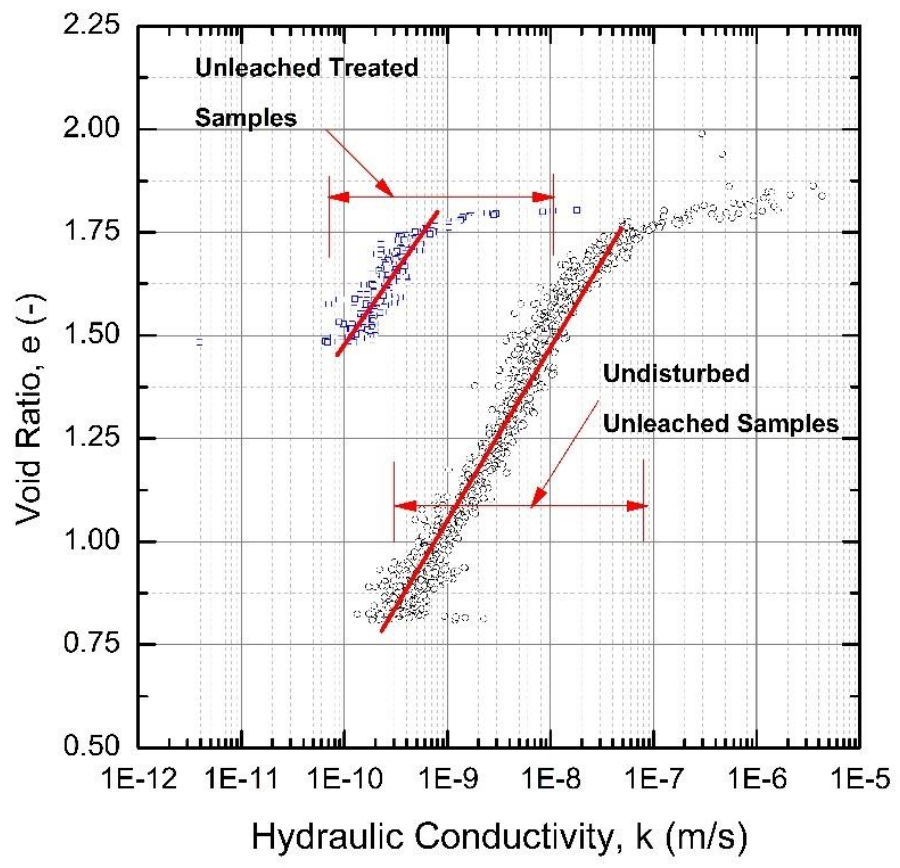

Figure 4-10 Hydraulic conductivity of undisturbed unleached and unleached treated samples 


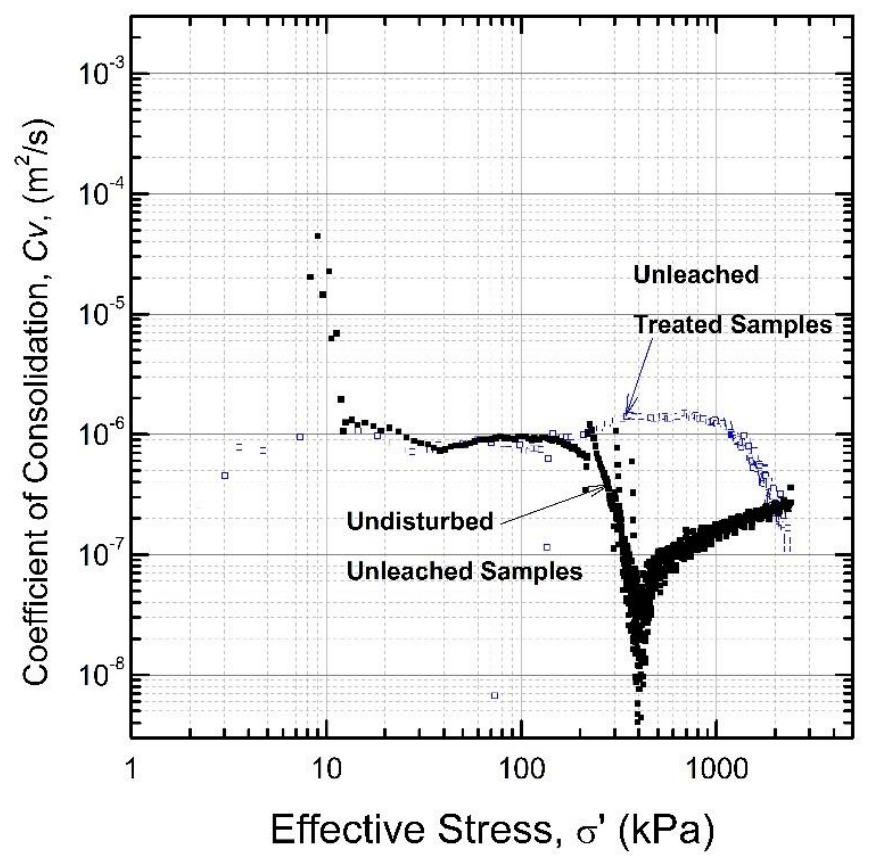

Figure 4-11 $C_{v}-\log p$ curves of undisturbed unleached and unleached treated samples

\subsubsection{Compressibility of cement treated leached Champlain Sea clay}

The main objective of this part was to observe how the salinity level impacts the compressibility of cement-treated samples. Five samples were leached to prepare for cement-treated samples under different leaching conditions. First, samples were leached to different salinity levels of 2.70, 1.60, $0.55, \& 0.35 \mathrm{~g} / \mathrm{L}$. Second, the leached clay samples were mixed with cement at a dosage of 50 $\mathrm{kg} / \mathrm{m}^{3}$ by wet-mixing method and cured for 7 days prior to conduct any test. Test results are shown in Figure 4-12 through Figure 4-16.

The $\varepsilon-\log \sigma^{\prime}$ compression curves of unleached and leached cement-treated samples are shown in Figure 4-12. The maximum vertical strain was obtained to be $10 \%$ for the cement-treated unleached clay sample at a vertical stress of 2.39 MPa. Whereas, for the leached treated samples. The maximum vertical strain was obtained at $12.4 \%, 11.0 \%, 13.5 \%$ \& $18 \%$ at salinity levels of 
$2.70,1.63,0.55 \& 0.35 \mathrm{~g} / \mathrm{L}$ respectively. From the test results, it can be said that leached treated samples display higher vertical strain compared to the unleached treated samples. All the test samples excluding the sample at $1.60 \mathrm{~g} / \mathrm{L}$ salinity show a general trend of increasing vertical strain with decreasing salinity levels in leached samples that mixed with cement.

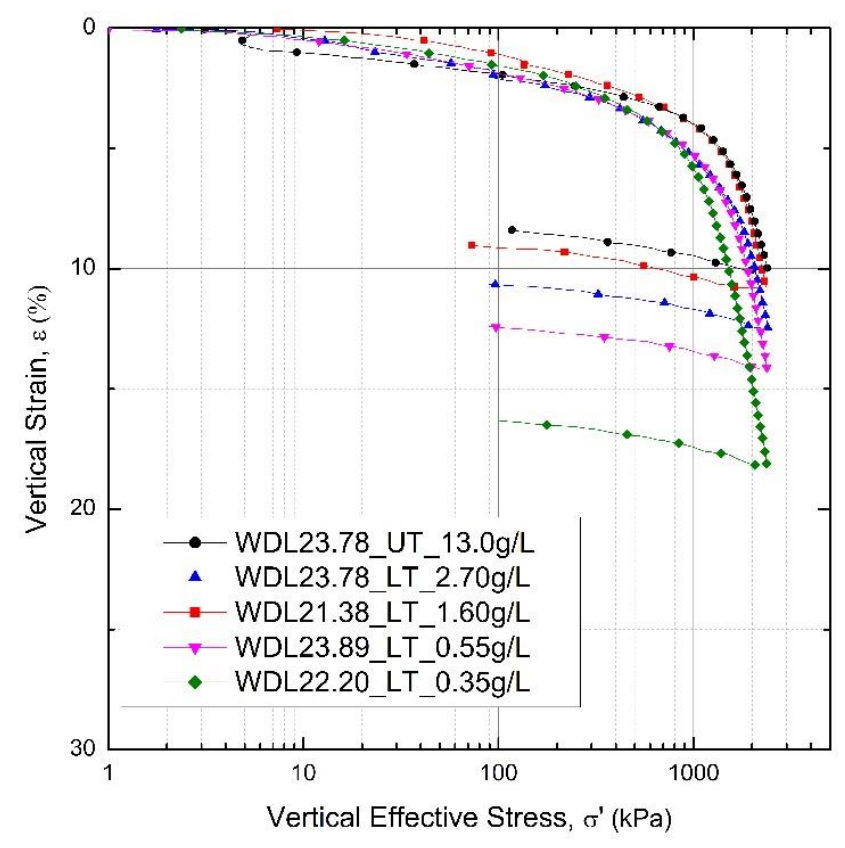

Figure 4-12 $\varepsilon-\log \sigma^{\prime} p$ compression curve for cement-mixed native and leached samples

The e- $\log \sigma^{\prime}$ plots of unleached and leached cement-treated samples are shown in the Figure 4-13. From the e- $\log \sigma^{\prime}$ curves for the cement-treated samples and cement-treated leached samples with salinity level above $1 \mathrm{~g} / \mathrm{L}$ yielding pressure was determined as $1200 \mathrm{kPa}$. Whereas, for the leached treated samples with salinity level below $1 \mathrm{~g} / \mathrm{L}$, the yielding pressure was recorded 1100 . Void ratio, $e_{o}$ remained the same for both leached and unleached treated samples. The consolidation parameters $C_{c}$ and $C_{r}$ are shown in Table 4-3. $C_{c}$ for the cement-treated unleached samples was obtained as 0.87 . On the other hand, for the cement-treated leached samples $C_{c}$ was obtained 0.88 , $0.90,1.04$ and 1.25 for salinity level of $2.70,1.60,0.55$ and $0.35 \mathrm{~g} / \mathrm{L}$ respectively. Therefore, from 
the test results reveal that leached treated samples exhibit higher value of $C_{c}$ than the unleached treated samples. And, it is also observed that $C_{c}$ value increases as salinity level goes down for the leached treated samples in the CRS testing machine. Whereas, recompression index $\left(C_{r}\right)$ values lies in between 0.05 to 0.06 for both cement-treated native and cement-treated leached samples.

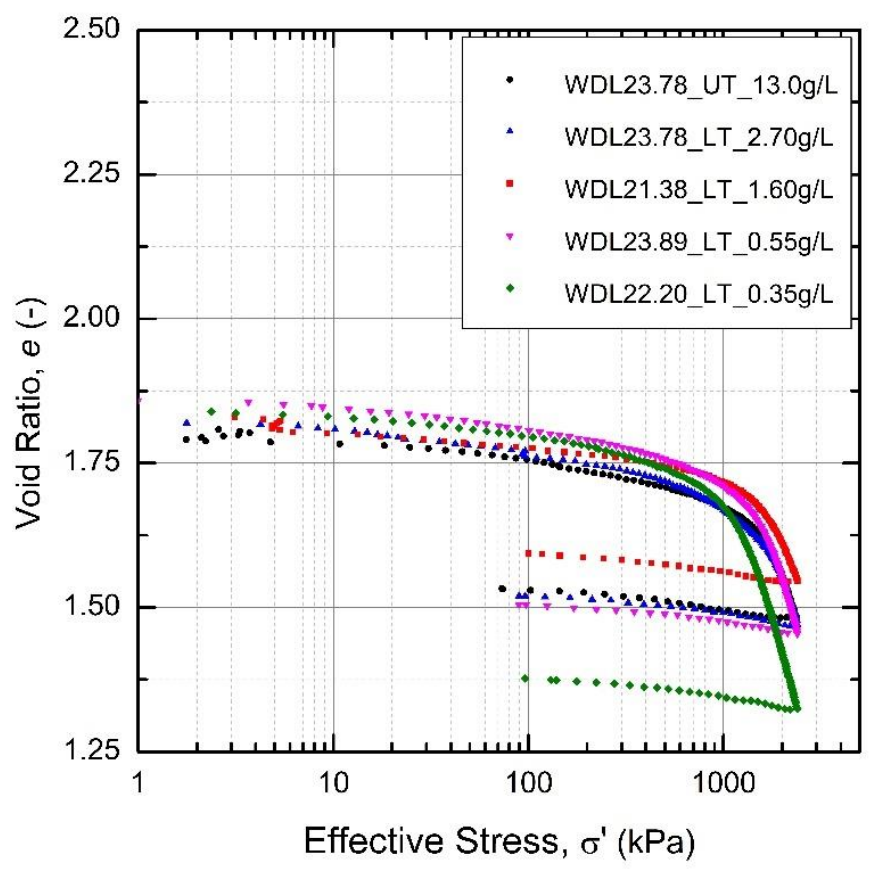

Figure 4-13 e- $\log p p^{\prime}$ curves of cement-treated Champlain Sea clay samples

$M_{v}$ for the cement-treated native and cement-treated leached samples were plotted against effective stress. For both cement-treated unleached and leached samples, $M_{v}$ value decreased with an increase of effective stress until the pre-consolidation pressure was reached, as shown in Figure 414. A modest increase of $M_{v}$ (ranging from $6 \times 10^{-4}$ to $2 \times 10^{-6} / \mathrm{kPa}$ ) was observed for the leached treated samples compared to unleached treated samples (ranging from $2 \times 10^{-4}$ to $3 \times 10^{-6} / \mathrm{kPa}$ ). 
Table 4-3 Summary of consolidation parameters for cement-treated leached and native samples

\begin{tabular}{|c|c|c|c|c|c|c|c|c|}
\hline $\begin{array}{l}\text { Type of } \\
\text { sample } \\
\text { s }\end{array}$ & $\begin{array}{c}\text { Sample } \\
\text { Designation }\end{array}$ & $\begin{array}{c}\text { Void } \\
\text { Ratio } \\
\left(e_{0}\right)\end{array}$ & $\begin{array}{l}\text { Maximum } \\
\text { vertical } \\
\text { strain }(\%)\end{array}$ & $\begin{array}{c}\text { Yielding pressure, } \\
p_{y}^{\prime}(\mathrm{kPa})\end{array}$ & $\begin{array}{c}\text { Comp. } \\
\text { index, } \\
c_{c-I}\end{array}$ & $\begin{array}{c}\text { Comp. } \\
\text { index, } \\
c_{c-I I}\end{array}$ & $\begin{array}{l}\text { Recomp. } \\
\text { index, } c_{r}\end{array}$ & $\frac{c_{c-I I}}{1+e_{0}}$ \\
\hline UT & $\begin{array}{c}\text { WDL23.78_ } \\
\text { UT_13.00 } \\
\text { g/L }\end{array}$ & 1.81 & 10.0 & 1200 & 0.05 & 0.87 & 0.05 & 0.310 \\
\hline LT & $\begin{array}{l}\text { WDL23.78 } \\
\text { LT_2.70 g/L }\end{array}$ & 1.81 & 12.4 & 1200 & 0.05 & 0.88 & 0.05 & 0.312 \\
\hline LT & $\begin{array}{l}\text { WDL21.38_ } \\
\text { LT_1.60 g/L }\end{array}$ & 1.82 & 11.0 & 1200 & 0.06 & 0.90 & 0.05 & 0.318 \\
\hline LT & $\begin{array}{l}\text { WDL22.58 } \\
\text { LT_0.55 g/L }\end{array}$ & 1.85 & 13.5 & 1100 & 0.06 & 1.04 & 0.05 & 0.364 \\
\hline LT & $\begin{array}{l}\text { WDL22.20_ } \\
\text { LT_0.35 g/L }\end{array}$ & 1.87 & 18.0 & 1100 & 0.06 & 1.25 & 0.06 & 0.430 \\
\hline
\end{tabular}

$M_{v}$ The void ratio was plotted against hydraulic conductivity, $\mathrm{k}$ for the unleached treated and leached treated samples as shown in Figure 4-15. For both samples, k value decreases with the decrease in void ratio. For the treated native samples, hydraulic conductivity value ranges from $7 \times 10^{-11}$ to $2 \times 10^{-9} \mathrm{~m} / \mathrm{s}$. whereas, the hydraulic conductivity value for the leached treated samples range from $8 \times 10^{-10}$ to $2 \times 10^{-7} \mathrm{~m} / \mathrm{s}$. The test results display that leached treated samples exhibit higher permeability compared to the unleached treated samples.

The coefficient of consolidation, $C_{v}$ for undisturbed unleached treated and leached treated samples were plotted against the effective stress as shown in Figure 4-16. $C_{v}$ is related to the coefficient of volume change and the hydraulic conductivity value. It is observed that the coefficient consolidation, $C_{v}$ for the leached treated native samples are slightly higher than the unleached treated samples. This is due to the higher permeability of leached treated samples compared to the unleached treated ones.

In short, the leached treated soil samples exhibit a higher compressibility and permeability compared to those of cement treated samples. 


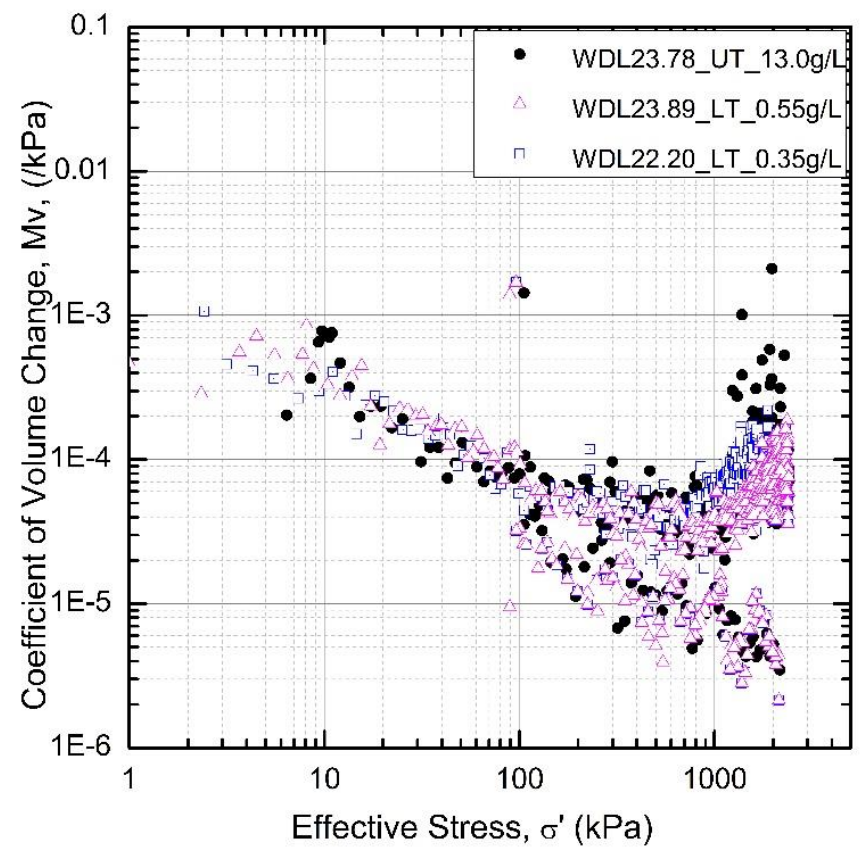

Figure 4-14 $M_{v}-\log p$ curves of cement-treated leached and unleached samples

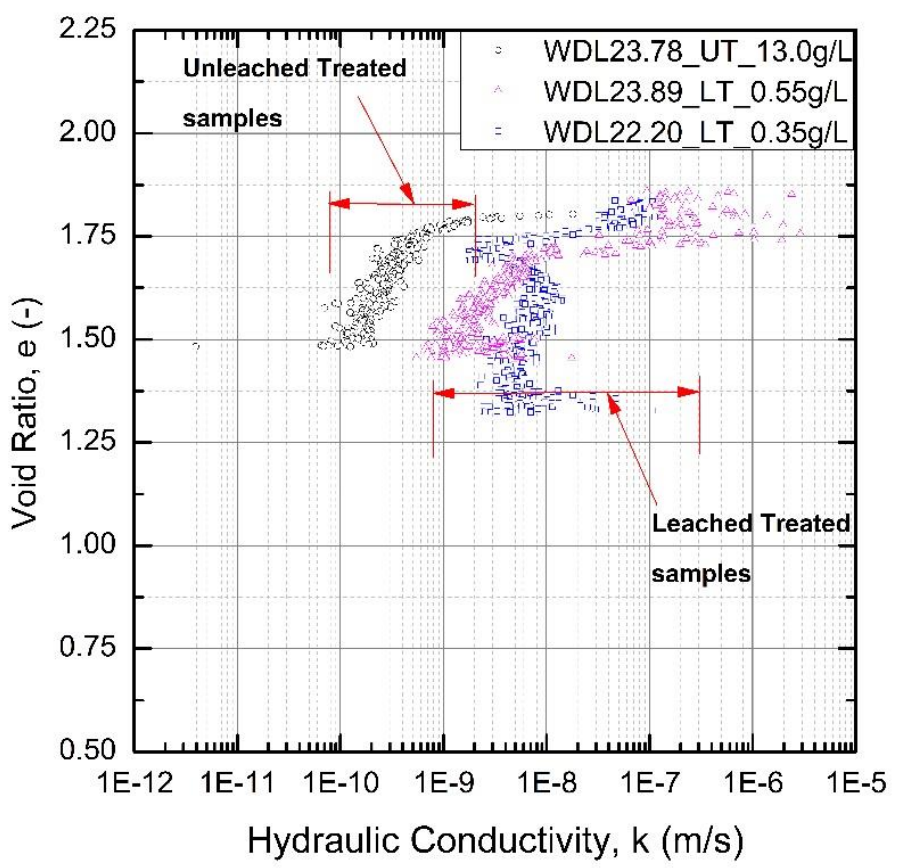

Figure 4-15 Hydraulic conductivity of cement-treated leached and unleached samples 


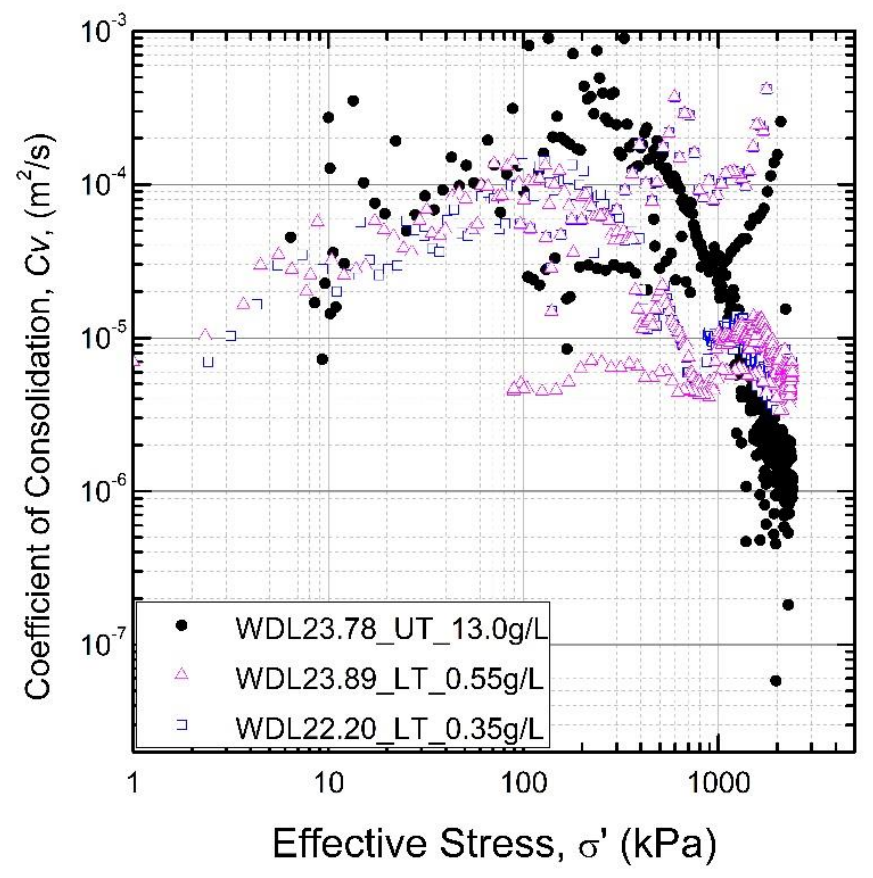

Figure 4-16 $C_{v}$-log $\square$ of cement-treated leached and unleached samples

\subsubsection{Summary of CRS test Results}

This section presented laboratory tests on the impact of salinity level on the compressibility behaviour of undisturbed and cement-treated Champlain Sea clay samples. Typical test results are shown from Figure 4-17 through Figure 4-21.

Based on the laboratory test results it seems that leached undisturbed soil sample exhibits a higher compressibility and permeability compared to those of undisturbed sample. Also, leaching causes a reduction in pre-consolidation pressure. The lower the salinity level of the sample, the higher the compressibility and permeability.

Cement can significantly improve the compressibility of Champlain Sea clay. Test results showed that due to cement mixing the compressibility of the clay has decreased to a considerable amount. Furthermore, cement mixing also decreases the permeability and increases the yielding pressure of the clay samples. 


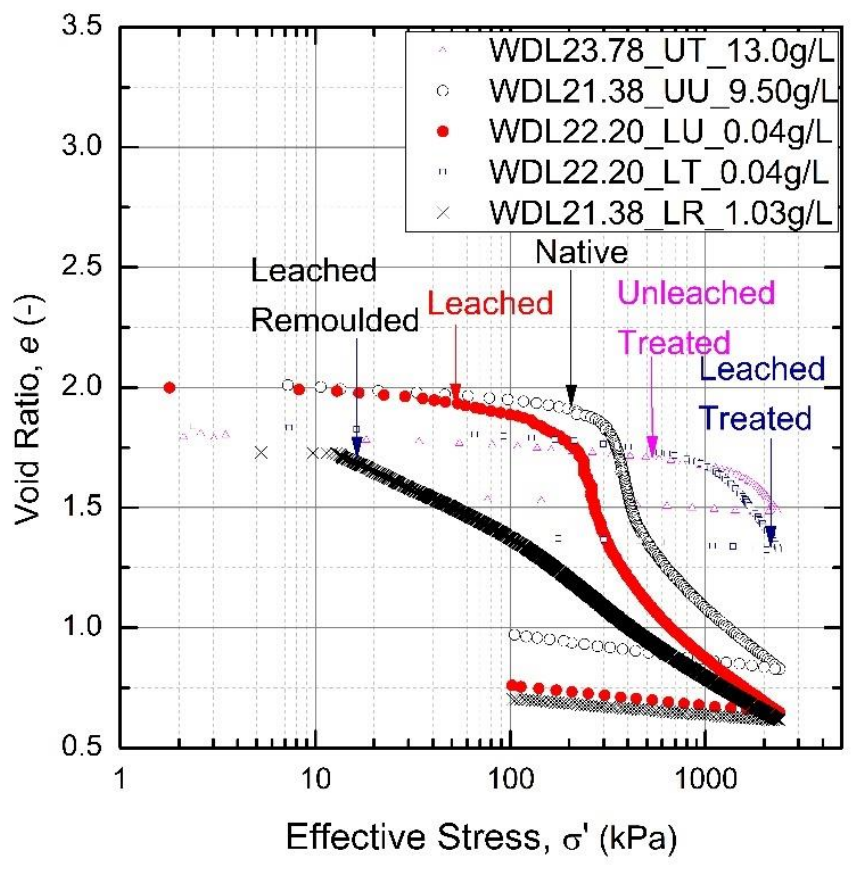

Figure 4-17 Typical e-log $p^{\prime}$ plot for different clay samples

Based on the laboratory test results, it was observed that leached treated soil samples exhibit slightly higher compressibility, and permeability compared to those of unleached treated samples. The lower the salinity level of the leached treated sample, the higher the compressibility and permeability.

Finally, all the parameters that obtained from the CRS tests results are summarized in Table 4-4. 


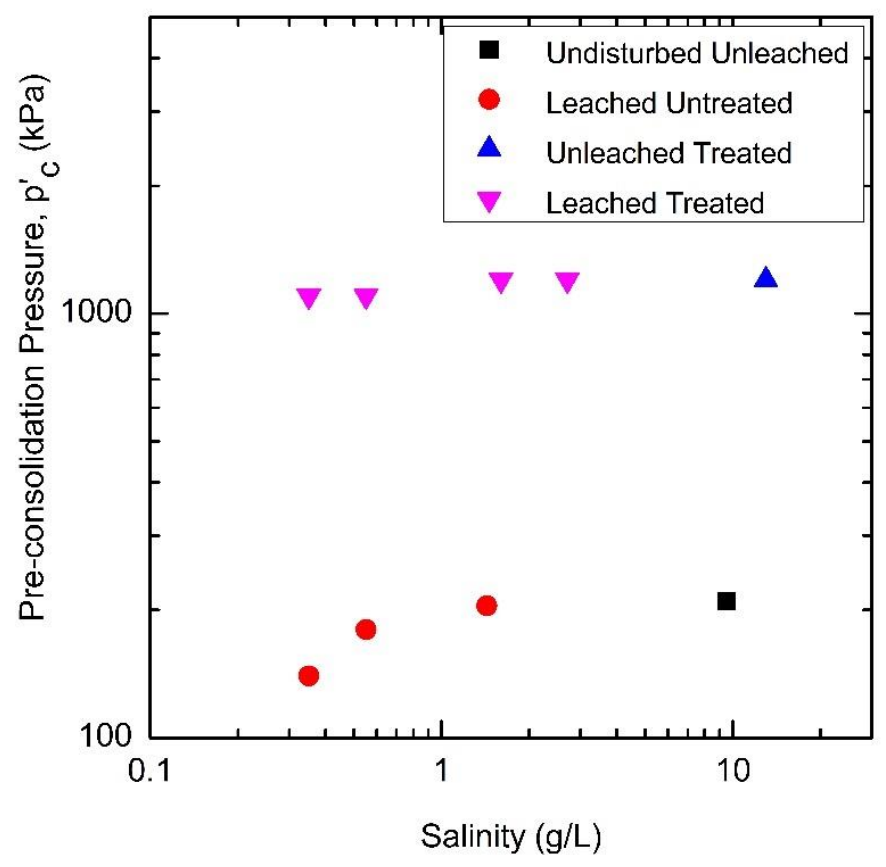

Figure 4-18 Impact of salinity on pre-consolidation pressure $\left(p_{c}^{\prime}\right)$ for different samples

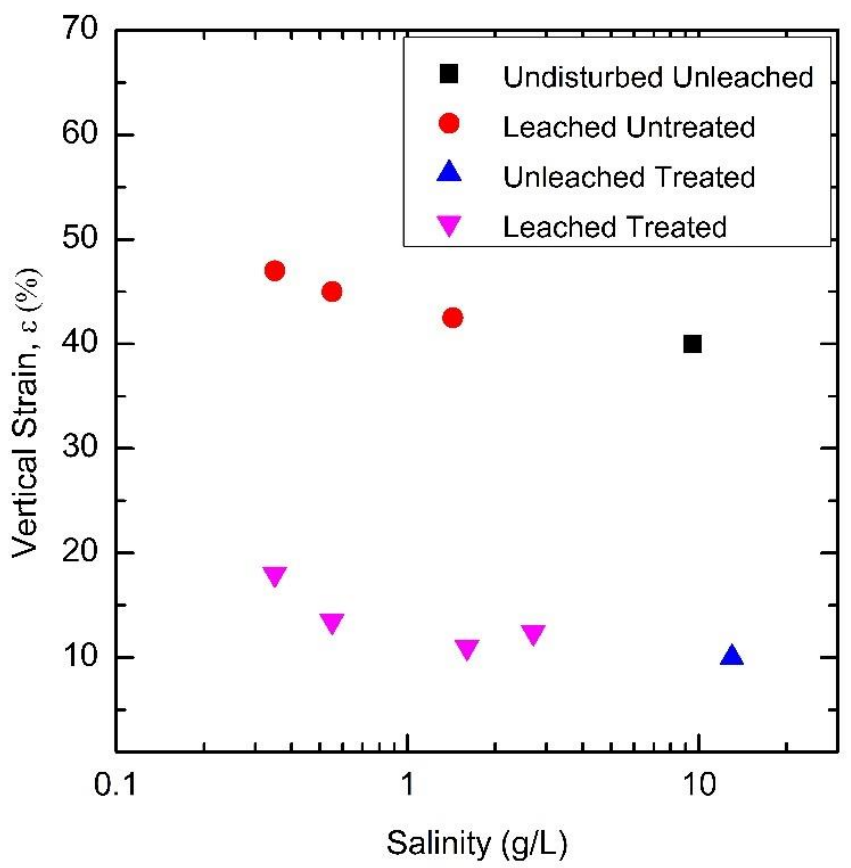

Figure 4-19 Impact of salinity on vertical strain $(\varepsilon)$ for different samples 


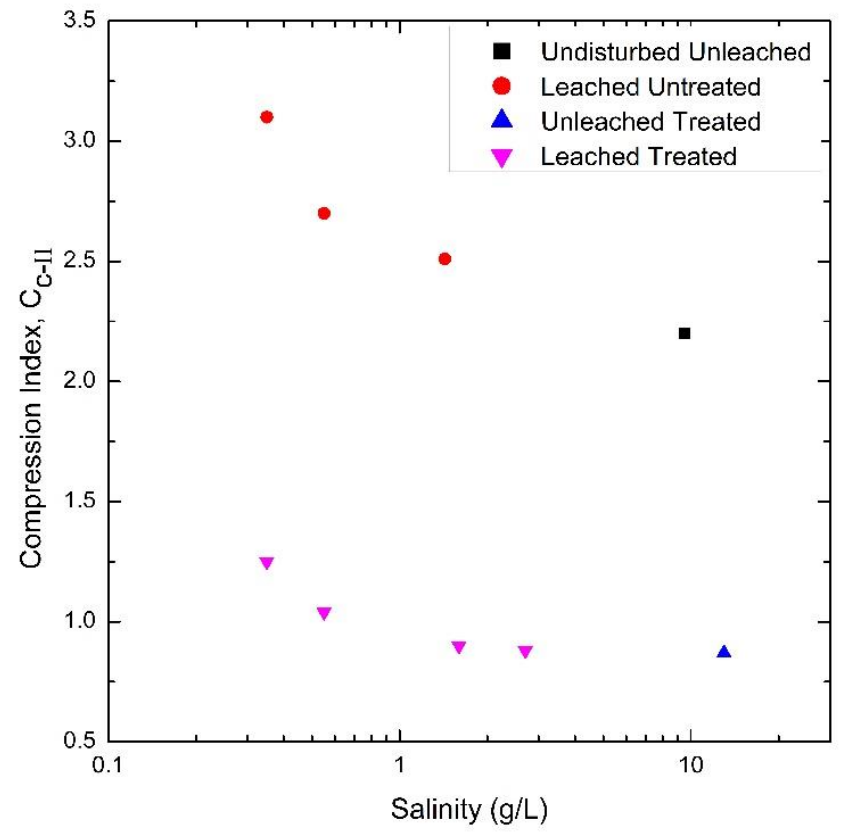

Figure 4-20 Impact of salinity on compression index $\left(c_{c}\right)$ for different samples

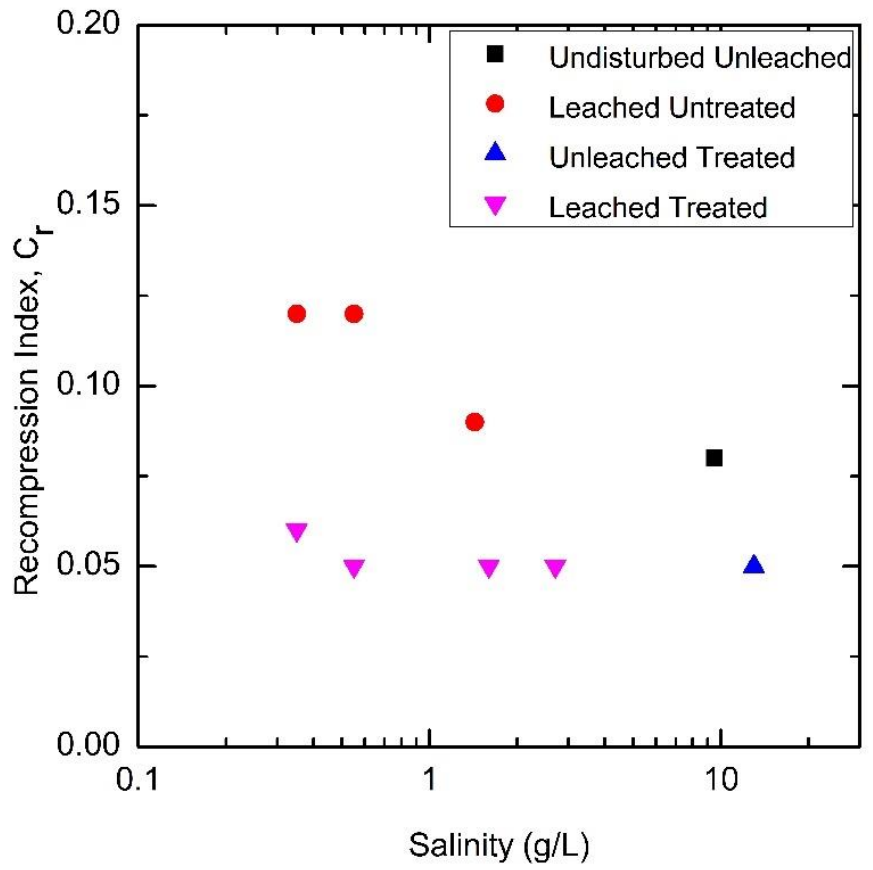

Figure 4-21 Impact of salinity on recompression index $\left(c_{r}\right)$ for different samples 
Table 4-4 Summary of consolidation parameters for all samples

\begin{tabular}{|c|c|c|c|c|c|c|c|c|c|c|c|c|c|c|c|}
\hline $\begin{array}{c}\text { Type of } \\
\text { Sample }^{1}\end{array}$ & $\begin{array}{c}\text { Sample } \\
\text { Designation }\end{array}$ & $\begin{array}{c}\text { Void } \\
\text { Ratio } \\
\left(e_{0}\right)\end{array}$ & $\begin{array}{l}\text { Maximum } \\
\text { vertical } \\
\text { strain }(\%)\end{array}$ & $\begin{array}{l}p_{c}^{\prime} \\
/ p_{y} \\
(\mathrm{kPa})\end{array}$ & $c_{c-I}$ & $c_{c-I I}$ & $c_{c-I I I}$ & $c_{r}$ & $\frac{c_{c}}{1+e_{0}}$ & $\begin{array}{c}\mathrm{k} \\
\left(\mathrm{x} 10^{-10}\right. \\
\mathrm{m} / \mathrm{sec})\end{array}$ & $\begin{array}{c}\mathrm{K} \text { at } p^{\prime}{ }_{c} \\
\left(\mathrm{x} 10^{-10}\right. \\
\mathrm{m} / \mathrm{sec})\end{array}$ & $\begin{array}{c}\mathrm{Mv} \\
(\mathrm{x} 10-5 \\
\left.\mathrm{m}^{2} / \mathrm{kN}\right)\end{array}$ & $\begin{array}{c}\mathrm{Mv} \text { at } p_{c}^{\prime} \\
\left(\mathrm{x} 10^{-7}\right. \\
\left.\mathrm{m}^{2} / \mathrm{sec}\right)\end{array}$ & $\begin{array}{c}\mathrm{Cv} \\
\left(\mathrm{x} 10^{-7}\right. \\
\left.\mathrm{m}^{2} / \mathrm{se}\right)\end{array}$ & $\begin{array}{c}\mathrm{Cv} \text { at } p_{c}^{\prime} \\
\left(\mathrm{x} 10^{-7}\right. \\
\left.\mathrm{m}^{2} / \mathrm{sec}\right)\end{array}$ \\
\hline UU & $\begin{array}{l}\text { WDL21.38_ } \\
\text { UU_9.50 g/L }\end{array}$ & 1.99 & 40.0 & 210 & 0.13 & 2.20 & 0.62 & 0.08 & 0.736 & $3.0-700$ & 347.0 & $\begin{array}{c}2.0- \\
100.0\end{array}$ & 3110.0 & $\begin{array}{c}50- \\
1000\end{array}$ & 113 \\
\hline $\mathrm{UU}^{3}$ & $\begin{array}{l}\text { WDL20.18_ } \\
\text { UU_9.25 g/L }\end{array}$ & 2.12 & - & 205 & - & 2.25 & - & 0.08 & 0.736 & $0.8-2.0$ & 1.5 & $1.0-300$ & 100.0 & $\begin{array}{c}0.05- \\
3.0\end{array}$ & 0.8 \\
\hline $\mathrm{UU}^{2}$ & $\begin{array}{l}\text { WDL38.80_ } \\
\text { UU_19.81 g/L }\end{array}$ & 1.99 & - & 310 & - & 2.32 & 0.73 & 0.10 & 0.776 & - & 10.0 & - & 200.0 & - & 3.0 \\
\hline LU & $\begin{array}{l}\text { WDL24.98_ } \\
\text { LU_1.43 g/L }\end{array}$ & 2.03 & 42.5 & 205 & 0.25 & 2.51 & 0.81 & 0.09 & 0.828 & $\begin{array}{c}6.0- \\
2000.0\end{array}$ & 368.0 & $\begin{array}{c}2.0- \\
150.0\end{array}$ & 3390.0 & $\begin{array}{l}100- \\
1000\end{array}$ & 27.0 \\
\hline $\mathrm{LU}$ & $\begin{array}{l}\text { WDL22.20_ } \\
\text { LU_0.55 g/L }\end{array}$ & 2.10 & 45.0 & 180 & 0.19 & 2.70 & 0.58 & 0.12 & 0.870 & $\begin{array}{c}6.0- \\
2000.0\end{array}$ & 971.0 & $\begin{array}{c}2.0- \\
150.0\end{array}$ & 8690.0 & $\begin{array}{l}100- \\
1000\end{array}$ & 114.0 \\
\hline $\mathrm{LU}$ & $\begin{array}{l}\text { WDL22.58_ } \\
\text { LU_0.35 g/L }\end{array}$ & 2.13 & 47.0 & 140 & 0.12 & 3.10 & 0.70 & 0.12 & 0.990 & $\begin{array}{c}6.0- \\
2000.0\end{array}$ & 992.0 & $\begin{array}{c}2.0- \\
150.0\end{array}$ & 3910.0 & $\begin{array}{l}100- \\
1000\end{array}$ & 76.6 \\
\hline $\mathrm{LU}^{2}$ & $\begin{array}{l}\text { WDL38.80_ } \\
\text { LU_0.79 g/L }\end{array}$ & 1.94 & - & 320 & - & 3.61 & 0.73 & 0.10 & 0.783 & - & 9.0 & - & 2000.0 & - & 0.02 \\
\hline UT & $\begin{array}{l}\text { WDL23.78_U } \\
\mathrm{T} \_13.00 \mathrm{~g} / \mathrm{L}\end{array}$ & 1.81 & 10.0 & 1200 & 0.05 & 0.87 & N/A & 0.05 & 0.310 & $0.7-20.0$ & 6.0 & $0.2-60.0$ & 552.0 & $\begin{array}{c}50- \\
2000\end{array}$ & 11.2 \\
\hline
\end{tabular}




\begin{tabular}{|c|c|c|c|c|c|c|c|c|c|c|c|c|c|c|c|}
\hline $\begin{array}{l}\text { Type of } \\
\text { Sample }^{1}\end{array}$ & $\begin{array}{c}\text { Sample } \\
\text { Designation }\end{array}$ & $\begin{array}{c}\text { Void } \\
\text { Ratio } \\
\left(e_{0}\right)\end{array}$ & $\begin{array}{l}\text { Maximum } \\
\text { vertical } \\
\text { strain }(\%)\end{array}$ & $\begin{array}{c}p_{c}^{\prime} \\
/ p_{y} \\
(\mathrm{kPa})\end{array}$ & $c_{c-I}$ & $c_{c-I I}$ & $c_{C-I I I}$ & $c_{r}$ & $\frac{c_{c}}{1+e_{0}}$ & $\begin{array}{c}\mathrm{k} \\
\left(\mathrm{x} 10^{-10}\right. \\
\mathrm{m} / \mathrm{sec})\end{array}$ & $\begin{array}{c}\mathrm{K} \text { at } p^{\prime}{ }_{c} \\
\left(\mathrm{x} 10^{-10}\right. \\
\mathrm{m} / \mathrm{sec})\end{array}$ & $\begin{array}{c}\mathrm{Mv} \\
(\mathrm{x} 10-5 \\
\left.\mathrm{m}^{2} / \mathrm{kN}\right)\end{array}$ & $\begin{array}{c}\mathrm{Mv} \text { at } p_{c}^{\prime} \\
\left(\mathrm{x} 10^{-7}\right. \\
\left.\mathrm{m}^{2} / \mathrm{sec}\right)\end{array}$ & $\begin{array}{c}\mathrm{Cv} \\
\left(\mathrm{x} 10^{-7}\right. \\
\left.\mathrm{m}^{2} / \mathrm{se}\right)\end{array}$ & $\begin{array}{l}\mathrm{Cv} \text { at } p_{c}^{\prime} \\
\left(\mathrm{x} 10^{-7}\right. \\
\left.\mathrm{m}^{2} / \mathrm{sec}\right)\end{array}$ \\
\hline $\mathrm{UT}^{2}$ & $\begin{array}{c}\text { WDL38.80_U } \\
\text { T_19.81 g/L }\end{array}$ & 1.67 & - & 1050 & - & 0.52 & N/A & 0.04 & 0.195 & - & 10.0 & - & 300.0 & - & 300.0 \\
\hline $\mathrm{LT}$ & $\begin{array}{c}\text { WDL23.78_L } \\
\text { T_2.70 g/L }\end{array}$ & 1.82 & 12.4 & 1200 & 0.05 & 0.88 & N/A & 0.05 & 0.312 & $\begin{array}{c}8.0- \\
2000.0\end{array}$ & 1.7 & $0.3-20.0$ & 550.0 & $\begin{array}{l}600- \\
2000\end{array}$ & 12.0 \\
\hline LT & $\begin{array}{c}\text { WDL21.38_L } \\
\text { T_1.60 g/L }\end{array}$ & 1.83 & 11.0 & 1200 & 0.06 & 0.90 & N/A & 0.05 & 0.318 & $\begin{array}{c}8.0- \\
2000.0\end{array}$ & 1.6 & $0.3-20.0$ & 800.0 & $\begin{array}{l}600- \\
2000\end{array}$ & 2.4 \\
\hline LT & $\begin{array}{c}\text { WDL22.58_L } \\
\text { T_0.55 g/L }\end{array}$ & 1.86 & 13.5 & 1100 & 0.06 & 1.04 & N/A & 0.05 & 0.364 & $\begin{array}{c}8.0- \\
2000.0\end{array}$ & 23.8 & $0.3-20.0$ & 852.0 & $\begin{array}{l}600- \\
2000\end{array}$ & 65.0 \\
\hline LT & $\begin{array}{c}\text { WDL22.20_L } \\
\text { T_0.35 g/L }\end{array}$ & 1.91 & 18.0 & 1100 & 0.06 & 1.25 & N/A & 0.06 & 0.430 & $\begin{array}{c}8.0- \\
2000.0\end{array}$ & 58.0 & $0.3-20.0$ & 830.0 & $\begin{array}{l}600- \\
2000\end{array}$ & 110.0 \\
\hline $\mathrm{LT}^{2}$ & $\begin{array}{c}\text { WDL38.80_L } \\
\text { T_0.79 g/L }\end{array}$ & 1.65 & - & 1200 & - & 0.67 & N/A & 0.03 & 0.253 & - & 2.0 & - & 500.0 & - & 3.0 \\
\hline \multicolumn{16}{|c|}{ Notes 1: UU-Undisturbed Unleached, LU-Leached Untreated, UT-Unleached Treated, LT-Leached Treated } \\
\hline \multicolumn{16}{|c|}{ Note 2: Test results from Ahmad (2018) } \\
\hline Note 3: & sults from & al. & & & & & & & & & & & & & \\
\hline
\end{tabular}




\subsection{Shear Strength Tests Result and Analysis}

\subsubsection{Leaching impact on the undisturbed Champlain Sea clay}

This section presented and compared the impact of leaching on the shear strength of Champlain Sea clay. In this regard, both CIU triaxial and mini vane shear tests were conducted.

\subsubsection{CIU triaxial test}

A total of $6 \mathrm{CIU}$ tests were conducted on undisturbed leached samples and native samples. Unleached sample was obtained from the depth between 20 to $25 \mathrm{~m}$ at salinity level 9.5 to $15 \mathrm{~g} / \mathrm{L}$. A total of 4 CIU tests were conducted on two leached samples (salinity levels of 2.75 and 1.03 $\mathrm{g} / \mathrm{L}$ ) that were obtained from leaching of native samples (extracted from 20 to $25 \mathrm{~m}$ depth) in the laboratory with distilled water. Test results are shown in Figure 4-22 through Figure 4-24.

Typical stress-strain curves were plotted for undisturbed unleached and leached untreated soil samples as shown in Figure 4-22. From the result, it was observed that for the same consolation stress that native soil exhibits a higher deviator stress value compared to the leached one. Test results display that a small reduction in soil modulus, the $\mathrm{E}$ was obtained when the natural samples were leached, which may be due to an increase in compressibility of the leached samples. Similar result was also reported for the clay soil in Doha by Ismael (1993).

The deviator stress was normalized with the consolidation pressure and shown in Figure 4-23. It is evident after normalizing the deviator stress that native soil sample still displays a higher value than that of leached one. The decrease in normalized deviator stress is possibly due to the removal of salt from the soil. Similar result was also reported by Woo \& Moh (1977).

The effective stress paths for both undisturbed native and leached samples are shown in Figure 424 , where the failure envelopes were drawn by the straight lines passing through the origin. The angle of inclination, $\alpha$ along with other strength parameters are also shown in Table 4-4. The friction angle was computed from $\sin \alpha=\tan \emptyset^{\prime}$. 


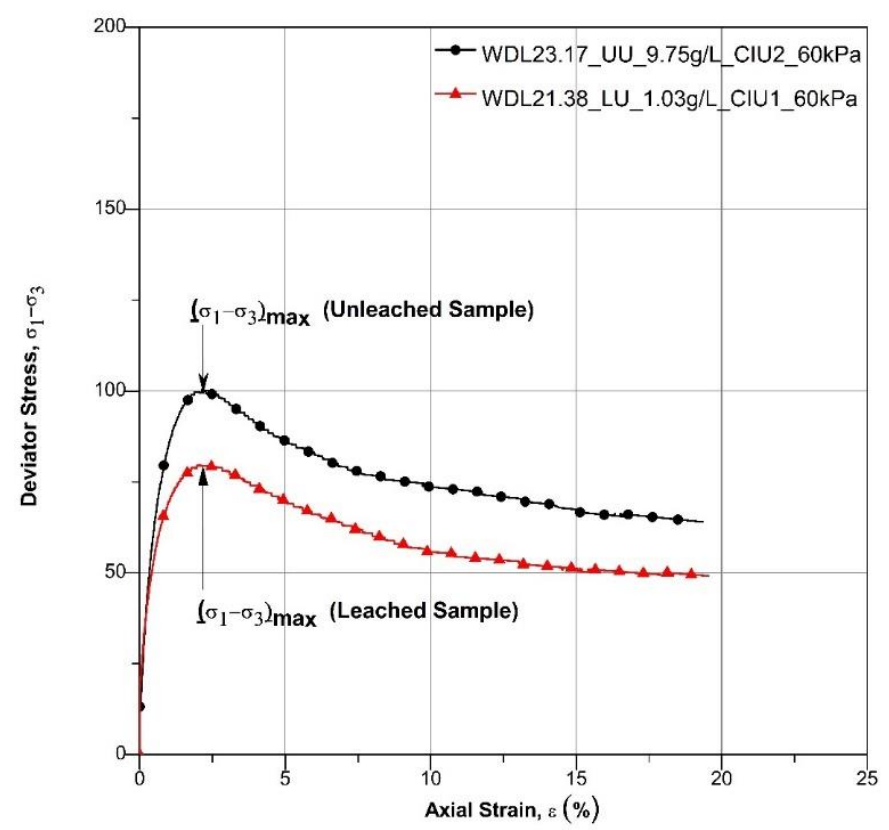

Figure 4-22 Typical deviator stress vs axial strain from CIU triaxial tests for undisturbed unleached and leached soil sample

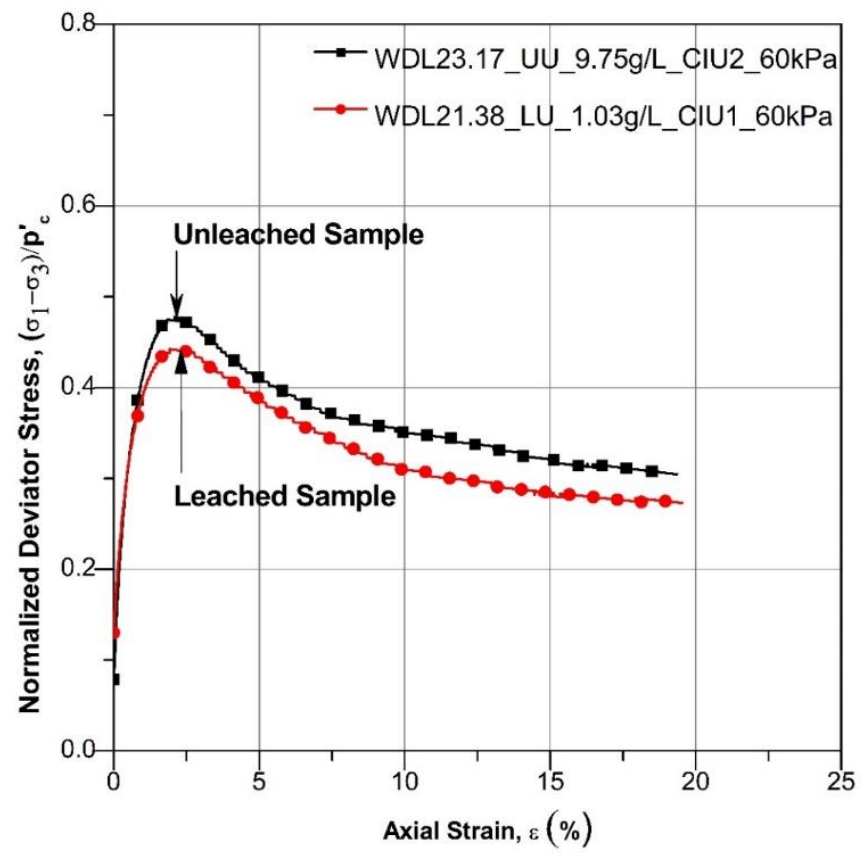

Figure 4-23 Comparison of normalized deviator stress-strain for undisturbed unleached and leached soil sample 
Table 4-5 Shear strength parameters of the undisturbed native and leached samples

\begin{tabular}{|c|c|c|c|c|c|c|c|}
\hline $\begin{array}{c}\text { Sample } \\
\text { Type }^{1}\end{array}$ & $\begin{array}{c}\text { Sample } \\
\text { Depth } \\
\text { (m) }\end{array}$ & $\begin{array}{l}\text { Salinity } \\
\text { level } \\
(\mathrm{g} / \mathrm{L})\end{array}$ & $\begin{array}{c}\mathrm{E} \\
(\mathrm{kPa})\end{array}$ & $\begin{array}{c}\text { Cohesion } \\
c^{\prime}(\mathbf{k P a})\end{array}$ & $\begin{array}{l}\text { Inclination } \\
\text { Angle, } \alpha \\
\text { (Degree) }\end{array}$ & $\begin{array}{l}\text { Friction } \\
\text { Angle, } \emptyset^{\prime} \\
\text { (Degree) }\end{array}$ & $\begin{array}{c}\text { Average } \\
\text { Friction } \\
\text { Angle, } \emptyset^{\prime} \\
\text { (Degree) }\end{array}$ \\
\hline UU & 23.17 & 9.75 & 7100 & 8.5 & $34.0^{\circ}$ & $42.8^{\circ}$ & \multirow[t]{2}{*}{$42.7^{\circ}$} \\
\hline $\mathrm{UU}$ & 23.17 & 9.75 & 7300 & 6.8 & $36.9^{\circ}$ & $42.6^{\circ}$ & \\
\hline UU & 25.20 & 15.0 & 6700 & 8.8 & $33.7^{\circ}$ & $41.8^{\circ}$ & \multirow[t]{2}{*}{$41.9^{\circ}$} \\
\hline UU & 25.20 & 15.0 & 6500 & 9.2 & $33.9^{\circ}$ & $42.1^{\circ}$ & \\
\hline LU & 23.17 & 2.75 & 5700 & 9.7 & $27.0^{\circ}$ & $30.7^{\circ}$ & \multirow[t]{2}{*}{$30.7^{\circ}$} \\
\hline $\mathrm{LU}$ & 23.17 & 2.75 & 5500 & 8.1 & $27.1^{\circ}$ & $30.8^{\circ}$ & \\
\hline $\mathrm{LU}$ & 21.38 & 1.03 & 3450 & 6.0 & $23.1^{\circ}$ & $25.3^{\circ}$ & \multirow[t]{2}{*}{$22.8^{\circ}$} \\
\hline LU & 21.38 & 1.03 & 3300 & 13.3 & $19.2^{\circ}$ & $20.4^{\circ}$ & \\
\hline
\end{tabular}

As mentioned in the previous section, the shear strength values were taken from the residual strength where a tangential line is drawn to the stress-path at the end of the CIU test. From the test results, the average cohesion $\left(c^{\prime}\right)$ and angle of internal friction $\left(\varnothing^{\prime}\right)$ were determined as $7.6 \mathrm{kPa} \&$ $42.7^{\circ}$ and $9 \mathrm{kPa} \& 41.9^{\circ}$ for the undisturbed native soil sample respectively at two different depth. Whereas, $c^{\prime}, \emptyset^{\prime}$ was obtained to $8.9 \mathrm{kPa}, 32.3^{\circ}$ respectively for the leached samples at salinity levels of $2.75 \mathrm{~g} / \mathrm{L}$. Again, for salinity level $1.03 \mathrm{~g} / \mathrm{L}, c^{\prime}, \emptyset^{\prime}$ was obtained to $9 \mathrm{kPa} \& 22.8^{\circ}$. Although the $c^{\prime}$ value almost remained the same, it can be said that a reduction in $\emptyset^{\prime}$ is occurred due to the leaching. Similar findings were also reported by Woo and Moh (1977) and Ismael (1993). 


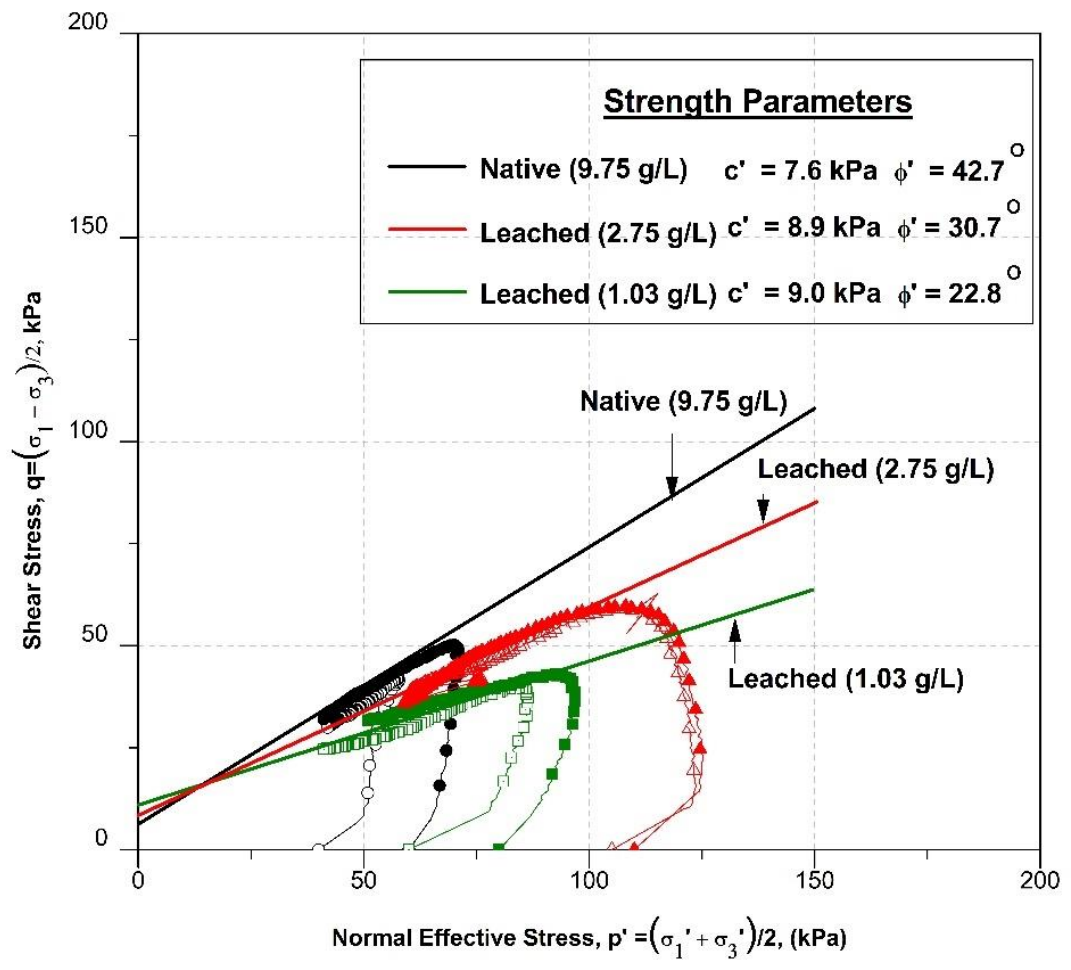

Figure 4-24 Effective stress paths and envelops of unleached and leached soil sample

\subsubsection{Mini vane shear test}

The shear strength of native and leached soil samples in both undisturbed and remoulded states were conducted using laboratory mini-vane. A total of 6 samples ( 3 native and 3 leached samples) were tested. Two vane shear tests were conducted for each sample and the average value was taken as the shear strength of the sample.

The undrained shear strengths of both undisturbed and remolded samples are shown in Table 4-4 and Figure 4-25. For the native soil the undrained shear strength ranged from 38 to $45 \mathrm{kPa}$. Whereas, it ranged from 12 to $25 \mathrm{kPa}$ for the leached soil. A significant reduction in undrained shear strength was observed due to leaching. On the other hand, the remolded shear strength was also declined remarkably for the leached soil (ranges from 0.5 to $1.5 \mathrm{kPa}$ ) compared to the undisturbed unleached soil (ranges from 7.5 to $10.5 \mathrm{kPa}$ ). Similar trend is also reported by another researcher (Woo \& Moh, 1977).

The sensitivity of soil was determined as the ratio of undrained shear strength of an undisturbed sample to that of a remolded sample. Test results show that the sensitivity for the native soil ranged 
from 4 to 6 . In contrast, for the leached soil sensitivity ranged from 13 to 24 . It seems that soil sensitivity has increased due to leaching. The lower the salinity level, the higher the sensitivity. This finding supports the results obtained by the other researchers (Bjerrum, 1954; Woo \& Moh, 1977). Test results are shown briefly in Table 4-4 and Figure 4-24.

Table 4-6 Summary of mini vane shear strength results for native and leached samples

\begin{tabular}{|c|c|c|c|c|c|}
\hline $\begin{array}{c}\text { Soil } \\
\text { Type }^{1}\end{array}$ & $\begin{array}{c}\text { Sample } \\
\text { depth (m) }\end{array}$ & $\begin{array}{c}\text { Salinity } \\
(\mathrm{g} / \mathrm{L})\end{array}$ & $\begin{array}{l}\text { Average undrained } \\
\text { shear strength of } \\
\text { undisturbed sample } \\
\text { (kPa) }\end{array}$ & $\begin{array}{l}\text { Average undrained } \\
\text { shear strength of } \\
\text { remolded sample } \\
\text { (kPa) }\end{array}$ & Sensitivity \\
\hline \multirow[t]{3}{*}{ UU } & 23.17 & 9.75 & 42.0 & 10.5 & 4 \\
\hline & 21.38 & 9.5 & 38.0 & 7.5 & 5 \\
\hline & 22.20 & 9.85 & 45.0 & 7.5 & 6 \\
\hline \multirow[t]{3}{*}{ LU } & 23.17 & 2.75 & 25.0 & 1.5 & 16 \\
\hline & 21.38 & 1.03 & 13.0 & 1.0 & 13 \\
\hline & 22.20 & 0.35 & 12.0 & 0.5 & 24 \\
\hline \multicolumn{6}{|c|}{ Note 1: UU-Undisturbed Unleached, LU-Leached Untreated } \\
\hline
\end{tabular}




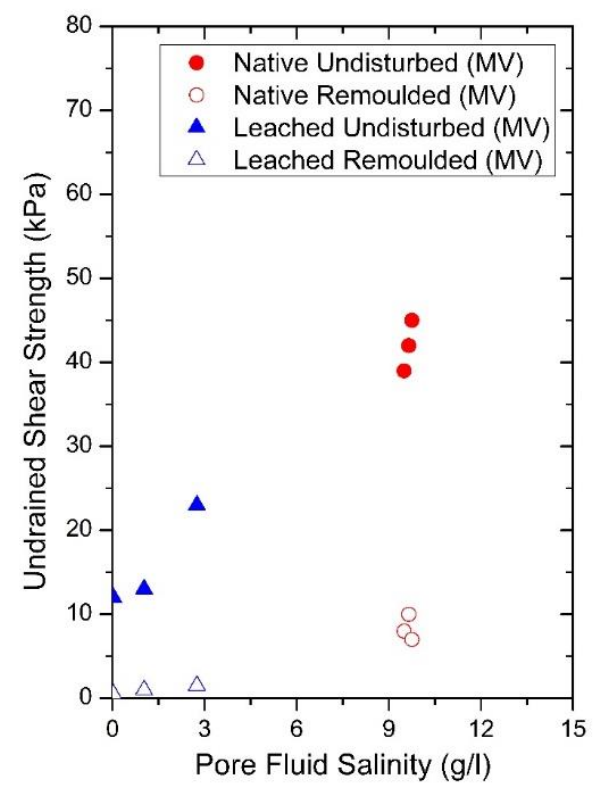

Figure 4-25 Undrained shear strength of soil sample at different leaching level

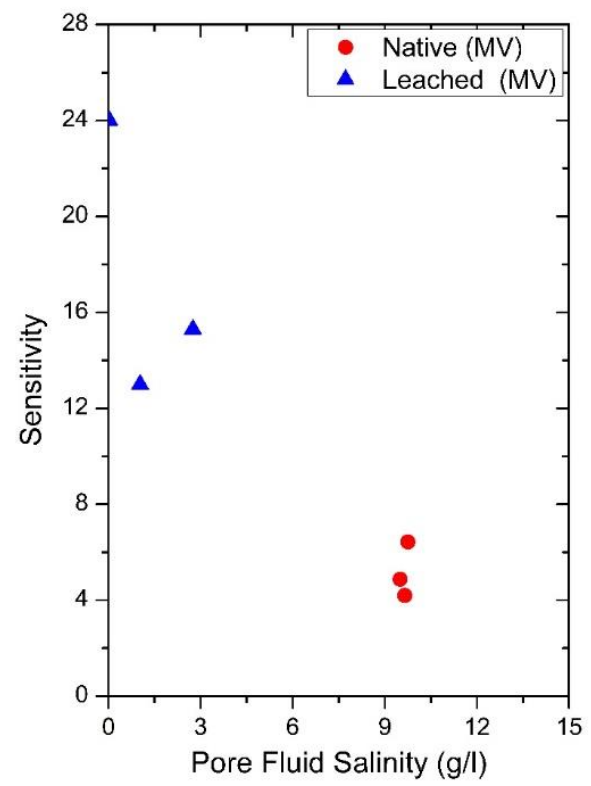

Figure 4-26 Sensitivity of soil at different leaching levels compared to the native soil 


\subsubsection{Shear strength of cement treated Champlain Sea clay}

A total of $4 \mathrm{CIU}$ tests were conducted on undisturbed samples and cement-treated samples. Soil samples were obtained from a depth of $23.17 \mathrm{~m}$ at a salinity level $9.5 \mathrm{~g} / \mathrm{L}$. A total of 2 CIU tests were conducted on native samples and another $2 \mathrm{CIU}$ tests were conducted on the samples from the same depth but mixed with cement. Test results are shown in Figure 4-27 and Figure 4-28.

The normalized deviator stress curves are shown in Figure 4-27. It is evident that cement-treated sample displays a much higher strength than that of untreated sample. Cement mixing increases the elastic modulus of Champlain Sea clay. The increase is due to the pozzolanic reaction occurs between soil and cement.

The effective stress paths of the cement-treated samples bring up several interesting features. Cement treatment changed the initial normally consolidated characteristics to a highly over consolidated clay behaviour as the yielding pressure is much higher than the consolidation pressure used in the study. The effective stress paths for both undisturbed native and cement-treated native samples were shown in Figure 4-28. Cohesion was zero for cement-treated samples as failure envelope passing through the origin was being considered due the shape of the stress path, and cohesion and internal friction is denoted as $\overline{c^{\prime}}$ and $\overline{\varnothing^{\prime}}$ respectively. From the test results, the angle of internal friction $\left(\emptyset^{\prime}\right)$ were determined as $42.7^{\circ}$ for the undisturbed untreated soil samples.

Whereas, $\bar{\emptyset}^{\prime}$ was increased to $52.3^{\circ}$ for the unleached cement-treated samples. A similar trend was reported for Bangkok soft clay by Uddin, et al. (1997). Strength parameter obtained the tests are shown in Table 4-6. 


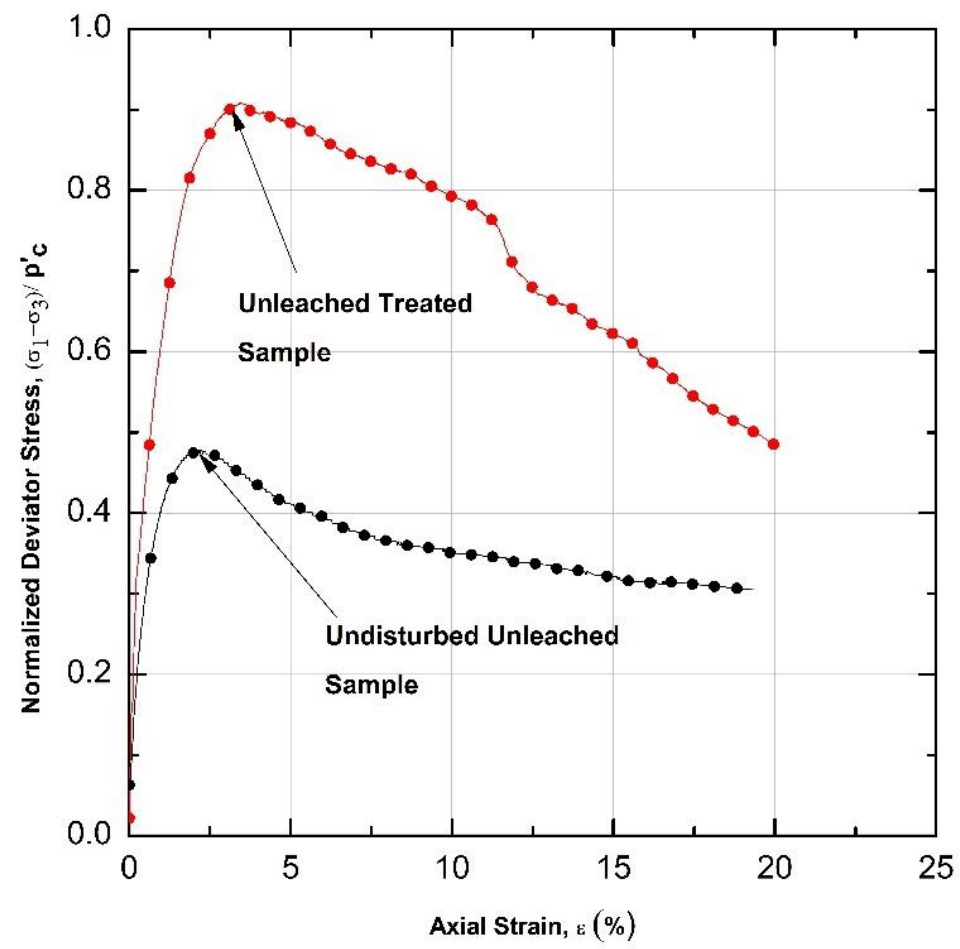

Figure 4-27 Comparison of normalized deviator stress-strain for undisturbed unleached and unleached treated samples

Table 4-7 Shear strength parameters of the undisturbed unleached and leached soil samples

\begin{tabular}{|c|c|c|c|c|c|c|c|}
\hline $\begin{array}{c}\text { Sample } \\
\text { Type }^{1}\end{array}$ & $\begin{array}{c}\text { Sample } \\
\text { Depth } \\
\text { (m) }\end{array}$ & $\begin{array}{c}\text { Salinity } \\
\text { level } \\
(\mathrm{g} / \mathrm{L})\end{array}$ & $\begin{array}{c}\mathbf{E} \\
(\mathbf{k P a})\end{array}$ & $\begin{array}{c}\text { Cohesion } \\
c^{\prime} / \overline{c^{\prime}} \\
(\mathbf{k P a})\end{array}$ & $\begin{array}{c}\text { Inclination } \\
\text { Angle, } \alpha \\
\text { (Degree) }\end{array}$ & $\begin{array}{c}\text { Friction } \\
\text { Angle, } \emptyset^{\prime} / \\
\emptyset^{\prime} \text { (Degree) }\end{array}$ & $\begin{array}{c}\text { Average } \\
\text { Friction } \\
\text { Angle, } \emptyset^{\prime} / \\
\overline{\emptyset^{\prime}} \text { (Degree) }\end{array}$ \\
\hline $\mathrm{UU}$ & 23.17 & 9.75 & 7100 & 8.5 & $34.0^{\circ}$ & $42.8^{\circ}$ & \multirow[t]{2}{*}{$42.7^{\circ}$} \\
\hline UU & 23.17 & 9.75 & 7300 & 6.8 & $36.9^{\circ}$ & $42.6^{\circ}$ & \\
\hline UT & 23.17 & 9.75 & 87500 & 0.0 & $39.6^{\circ}$ & $50.9^{\circ}$ & \multirow[t]{2}{*}{$52.3^{\circ}$} \\
\hline UT & 23.17 & 9.75 & 86000 & 0.0 & $40.8^{\circ}$ & $53.7^{\circ}$ & \\
\hline
\end{tabular}




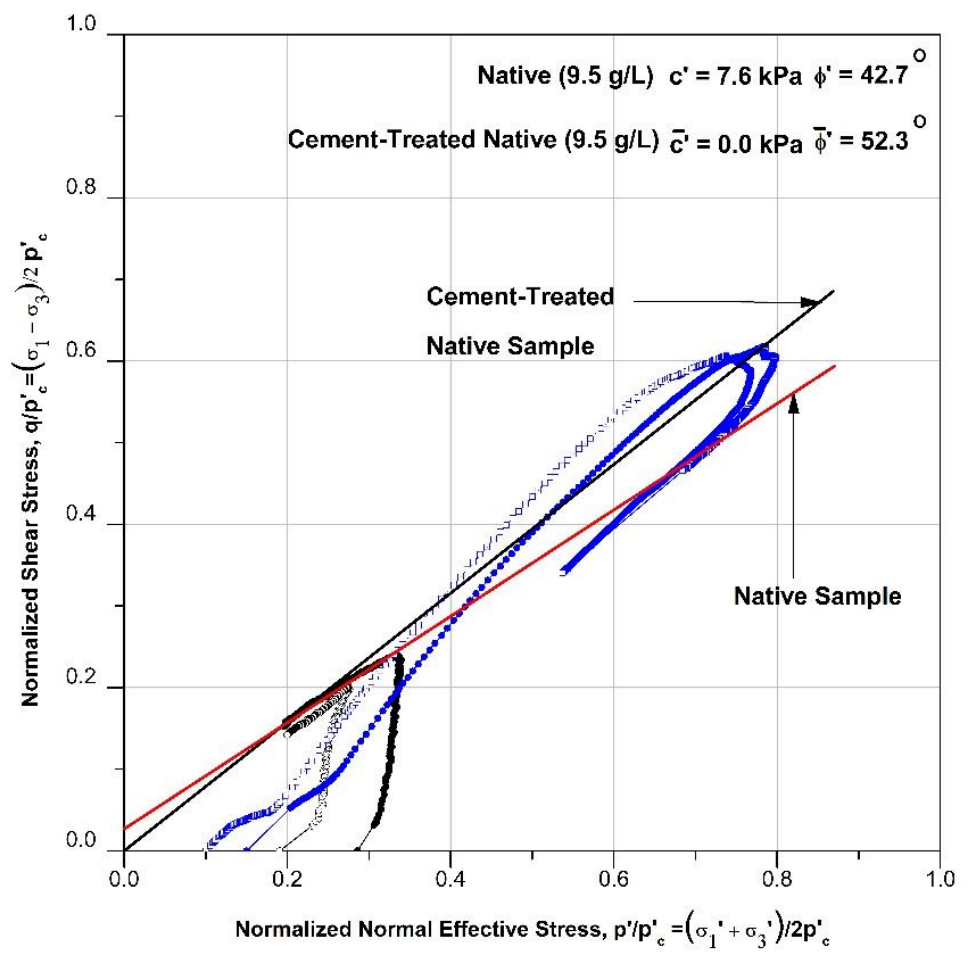

Figure 4-28 Effective stress paths and envelops of undisturbed unleached and unleached treated samples

\subsubsection{Shear strength of leached cement treated Champlain Sea clay}

A total of 4 CIU tests were conducted on cement-treated unleached and cement-treated leached samples. Native sample was obtained from $23.17 \mathrm{~m}$ depth at a salinity level of $9.5 \mathrm{~g} / \mathrm{L}$ was mixed with cement to prepare cement-treated samples. In order to prepare leached treated samples, a sample obtained from $23.17 \mathrm{~m}$ depth was first leached to salinity level of $1.03 \mathrm{~g} / \mathrm{L}$, and then mixed with cement according to the mix design. 2 CIU tests were conducted on cement mixed native samples and other 2 CIU tests were conducted on leached cement-treated samples. Test results are shown in the Figure 4-29 and Table 4-6.

From the test results, the angle of internal friction $\left(\bar{\emptyset}^{\prime}\right)$ were determined as $52.3^{\circ}$ for the unleached treated soil samples. Whereas, $\bar{\emptyset}^{\prime}$ was increased to $58.0^{\circ}$ for the leached treated samples at salinity 
levels of $1.03 \mathrm{~g} / \mathrm{L}$. Thus, it can be said that an increment in soil shear strength $\left(\bar{\emptyset}^{\prime}\right)$ is occurred due to the leached treated samples.

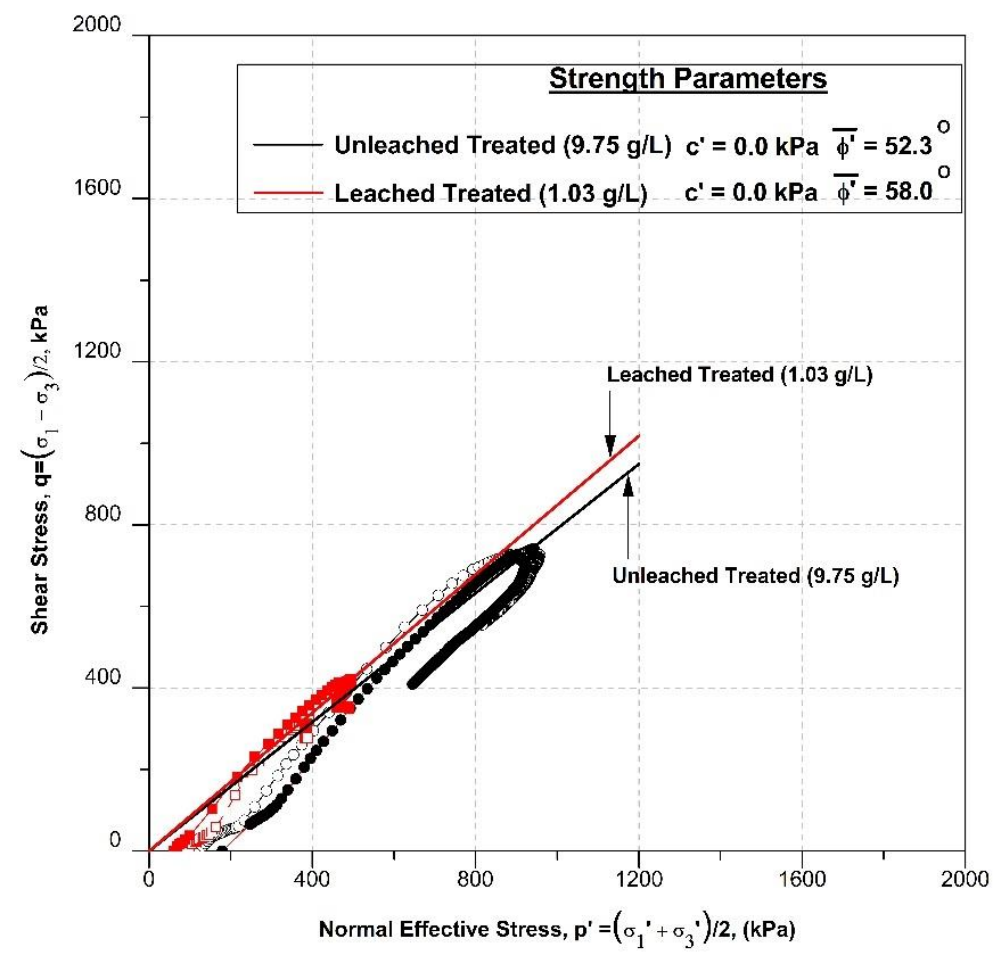

Figure 4-29 Effective stress paths and envelops of unleached treated and leached treated samples 
Table 4-8 Shear strength parameters for native, leached and cement mixed native soil samples

\begin{tabular}{|c|c|c|c|c|c|c|c|}
\hline $\begin{array}{c}\text { Sample } \\
\text { Type }^{1}\end{array}$ & $\begin{array}{c}\text { Sample } \\
\text { Depth } \\
\text { (m) }\end{array}$ & $\begin{array}{c}\text { Salinity } \\
\text { level } \\
(\mathrm{g} / \mathrm{L})\end{array}$ & $\begin{array}{c}\mathrm{E} \\
(\mathbf{k P a})\end{array}$ & $\begin{array}{c}\text { Cohesion } \\
\frac{c^{\prime}}{(\mathbf{k P a})}\end{array}$ & $\begin{array}{c}\text { Inclination } \\
\text { Angle, } \\
\overline{\boldsymbol{\alpha}} \text { (Degree) }\end{array}$ & $\begin{array}{c}\text { Friction } \\
\text { Angle, } \\
\emptyset^{\prime} \\
\text { (Degree) }\end{array}$ & $\begin{array}{c}\text { Average } \\
\text { Friction } \\
\text { Angle, } \overline{\emptyset^{\prime}} \\
\text { (Degree) }\end{array}$ \\
\hline UT & 23.17 & 9.75 & 87500 & 0.0 & $39.6^{\circ}$ & $50.9^{\circ}$ & \multirow[t]{2}{*}{$52.3^{\circ}$} \\
\hline UT & 23.17 & 9.75 & 86000 & 0.0 & $40.8^{\circ}$ & $53.7^{\circ}$ & \\
\hline LT & 21.38 & 1.03 & 54000 & 0.0 & $39.6^{\circ}$ & $59.2^{\circ}$ & \multirow[t]{2}{*}{$58.0^{\circ}$} \\
\hline LT & 21.38 & 1.03 & 52500 & 0.0 & $40.8^{\circ}$ & $56.8^{\circ}$ & \\
\hline & & & & & Leac & & \\
\hline
\end{tabular}

\subsubsection{Summary of shear strength tests results}

In order to determine shear strength parameters for undisturbed native and leached samples, both triaxial compression tests and vane shear tests were performed. Test results revealed that leaching results in a reduction in shear strength in the soil sample. The lower the salinity level of leached sample, the lower its shear strength. Furthermore, remolded undrained shear strength of leached is lower than the undisturbed unleached samples. Sensitivity of Champlain Sea clay increases with a reduction of salinity level.

Cement mixing has significantly improved the shear strength properties and modulus of clay samples. The increase is mainly due to the pozzolanic reaction that occurs between soil and cement.

Leached treated samples seems to exhibit a higher shear strength compared to that of native cement treated samples. More tests are required to confirm the strength parameters of the leached treated samples at different salinity levels. Summary of all CIU triaxial test results are shown in Table 4-9. 
Table 4-9 Summary of CIU triaxial test results for all samples

\begin{tabular}{|c|c|c|c|c|c|c|c|c|c|c|c|c|c|}
\hline $\begin{array}{c}\text { Sample } \\
\text { Type }^{1}\end{array}$ & $\begin{array}{c}\text { Sample } \\
\text { Depth } \\
\text { (m) }\end{array}$ & $\begin{array}{c}\text { Salinity } \\
\text { Level } \\
\text { (g/L) }\end{array}$ & $\begin{array}{c}\text { Cell } \\
\text { Pressure, } \\
\sigma_{3}\end{array}$ & $\begin{array}{c}\text { Back } \\
\text { Pressure, } \\
\sigma_{b}^{\prime}\end{array}$ & $\begin{array}{l}\text { Consolidation } \\
\text { pressure, } \sigma^{\prime}{ }_{c}\end{array}$ & $\begin{array}{c}\text { B } \\
\text { Value }\end{array}$ & $\begin{array}{c}\text { Max } \\
\text { Deviator } \\
\text { stress, } \\
\boldsymbol{\sigma}_{\text {dev }}^{\prime}\end{array}$ & $\begin{array}{c}\text { Max } \\
\text { stress } \\
\text { ratio } \\
\left(\sigma^{\prime}{ }_{1} /\right. \\
\left.\sigma^{\prime}{ }_{3}\right)\end{array}$ & $\begin{array}{c}\mathbf{E} \\
(\mathbf{k P a})\end{array}$ & $\begin{array}{c}\text { Cohesion } \\
c^{\prime} / \overline{c^{\prime}} \\
(\mathbf{k P a})\end{array}$ & $\begin{array}{c}\text { Inclination } \\
\text { Angle } \alpha \\
\text { (Degree) }\end{array}$ & $\begin{array}{l}\text { Friction } \\
\text { Angle, } \\
\frac{\emptyset^{\prime} /}{\emptyset^{\prime}} \\
\text { (Degree) }\end{array}$ & $\begin{array}{l}\text { Average } \\
\text { Friction } \\
\text { Angle, } \\
\emptyset^{\prime} / \overline{\emptyset^{\prime}} \\
\text { (Degree) }\end{array}$ \\
\hline UU & 23.17 & 9.75 & 460 & 400 & 60 & 0.97 & 105 & 8.5 & 7100 & 8.5 & $34.0^{\circ}$ & $42.8^{\circ}$ & $42.7^{\circ}$ \\
\hline UU & 23.17 & 9.75 & 440 & 400 & 40 & 0.98 & 82 & 6.0 & 7300 & 6.8 & $36.9^{\circ}$ & $42.6^{\circ}$ & \\
\hline UU & 25.20 & 15.0 & 480 & 400 & 80 & 0.99 & 115 & 7.9 & 6700 & 8.8 & $33.7^{\circ}$ & $41.8^{\circ}$ & $41.9^{\circ}$ \\
\hline UU & 25.20 & 15.0 & 460 & 400 & 60 & 0.97 & 102 & 8.1 & 6500 & 9.2 & $33.9^{\circ}$ & $42.1^{\circ}$ & \\
\hline LU & 23.17 & 2.75 & 510 & 400 & 110 & 0.98 & 185 & 3.6 & 5700 & 9.7 & $27.0^{\circ}$ & $30.7^{\circ}$ & $30.7^{\circ}$ \\
\hline LU & 23.17 & 2.75 & 505 & 400 & 105 & 0.99 & 175 & 3.5 & 5500 & 8.1 & $27.1^{\circ}$ & $30.8^{\circ}$ & \\
\hline $\mathrm{LU}$ & 21.38 & 1.03 & 480 & 400 & 80 & 0.94 & 85 & 4.2 & 3450 & 6.0 & $23.1^{\circ}$ & $25.3^{\circ}$ & $22.8^{\circ}$ \\
\hline LU & 21.38 & 1.03 & 460 & 400 & 60 & 0.96 & 72 & 4.0 & 3300 & 13.3 & $19.2^{\circ}$ & $20.4^{\circ}$ & \\
\hline UT & 23.17 & 9.75 & 760 & 600 & 160 & 0.89 & 1145 & 16.2 & 87500 & 0.0 & $39.6^{\circ}$ & $50.9^{\circ}$ & $52.3^{\circ}$ \\
\hline UT & 23.17 & 9.75 & 760 & 630 & 130 & 0.91 & 1030 & 9.1 & 86000 & 0.0 & $40.8^{\circ}$ & $53.7^{\circ}$ & \\
\hline LT & 21.38 & 1.03 & 760 & 670 & 90 & 0.87 & 850 & 22 & 54000 & 0.0 & $39.6^{\circ}$ & $59.2^{\circ}$ & $58.0^{\circ}$ \\
\hline LT & 21.38 & 1.03 & 760 & 710 & 50 & 0.90 & 610 & 12.5 & 52500 & 0.0 & $40.8^{\circ}$ & $56.8^{\circ}$ & \\
\hline
\end{tabular}




\section{SUMMARY AND CONCLUSIONS}

\subsection{Introduction}

The impact of salinity in the pore fluid on the compressibility and shear strength of the native and cement-treated Champlain Sea clay were investigated in this study.

For this study, a few undisturbed soil samples that obtained from 20 to $25 \mathrm{~m}$ depth of foundation of Waba dam, near Ottawa city, were first leached with distilled water in the geotechnical laboratory of Ryerson university. The salinity level from the native samples was between 9.5 to $15 \mathrm{~g} / \mathrm{L}$ depending on the depth of soil sample at the field. The salinity was leached to different levels of $2.75,1.60,1.43,0.55$, and $0.35 \mathrm{~g} / \mathrm{L}$. Cement was then mixed at a dosage of $50 \mathrm{~kg} / \mathrm{m}^{3}$ using the wet-mix method, and cement-treated samples were cured for 7 days before conducting any tests.

A series of CRS consolidation tests, triaxial compression tests, and vane shear tests were carried out in the laboratory. Test results were compared to investigate both impacts of cement mixing and leaching on the behaviour of Champlain Sea clay treated or without cement treatment.

\subsection{Conclusions of the Study}

Based on the test results, the following conclusions can be drawn:

1. Leaching resulted in a reduction in both liquid limit and plasticity. Leached soil samples display higher sensitivity than those of native ones. Leached soil samples exhibit slightly higher initial void ratio compared to the undisturbed native clay samples might be due to decrease in volume of solids (as salt was leached away from the soil) and errors occurred during sample preparation. The lower the salinity level of the leached samples, the higher the void ratio. Leaching leads to a reduction in pre-consolidation pressure of a clay sample. An increase in compressibility was observed due to leaching. Test results also reveal the lower the salinity level, the higher the compressibility of the leached soil sample. A leached soil sample exhibits a higher permeability compared to that of a native sample. A reduction in soil modulus and shear strength was also obtained from CIU triaxial and vane shear tests on leached samples compared to those of native samples.

2. Cement mixing results in a decrease in the initial void ratio and a significant increase in yielding pressure. Cement mixing significantly decreases the compressibility as well. 
Cement mixing also decreased the permeability of the native clay. Cement mixing also significantly increases the modulus and the shear strength of Champlain Sea clay. Changes in stress paths for the cement-treated sample were also observed due to the changes in soil consolidation behavior from normally consolidated state to highly over-consolidated state.

3. Leaching also affects the cement-treated sample as well. Void ratio almost remained the same for cement-treated leached and unleached samples. A higher permeability was observed for leached cement-treated samples. Strength parameters obtained for leached treated samples were greater than the respective parameters for unleached cement-treated samples. Conducting more triaxial tests on leached treated samples of different salinity will confirm the findings.

4. Leached treated samples exhibit almost the same yielding pressure as unleached treated samples. An increase in compressibility was observed for the leached treated samples compared to the unleached treated samples. Test results also reveal that the compressibility increases as salinity declines for the leached treated samples.

\subsection{Recommendations for Future Study}

1. Due to the capacity restriction of the CRS machine load cell, only the $50 \mathrm{~kg} / \mathrm{m}^{3}$ cement dosage was considered for this study. Influence of a higher cement dosage on the compressibility and properties of Champlain Sea clay is needed to be investigated since a dosage higher than the one used in this study is more practical in the practice.

2. Due to triaxial machine breakdown in the middle of research, only a limited number of triaxial tests were conducted on cement-treated samples. More tests with a wider range of salinity for cement-treated samples should be conducted to find a better picture of leaching impact on the shear strength of the cement-treated soil.

3. The impact of salinity levels above $2.70 \mathrm{~g} / \mathrm{L}$ and below $0.35 \mathrm{~g} / \mathrm{L}$ were not investigated in this study due to time restraint. More studies should be conducted at different salinity levels to provide a whole picture of salinity impact on shear strength and compressibility properties of Champlain Sea clay. 
4. Only Champlain Sea clay samples of 20-25m depth from a site near the city of Arnprior were considered in this research. More tests are required to be conducted on lower depth soil samples at this site or other regions with Champlain Sea clay.

5. Compressibility and shear strength parameters of 28 days cured cement-treated samples are also needed to be investigated and should be compared with those of 7 days cured samples test results. 


\section{APPENDICES}




\section{Appendix A- Sample Mix Design}




\begin{tabular}{|c|c|c|}
\hline \multicolumn{3}{|l|}{ PROJECT INFORMATION } \\
\hline Client & Boring Number & \\
\hline Project Name & Sample Number & 1 \\
\hline Sample Location & Sample Depth & 23.15 \\
\hline Specimen Description : Leda Clay & Specimen Remarks & \\
\hline \multicolumn{3}{|c|}{ MIX DESIGN (Based on FHWA Guidelines) } \\
\hline Symbol & Long name & \\
\hline \multicolumn{3}{|c|}{ Input } \\
\hline $\mathrm{Nm}$ & Number of mold to be used & 1 \\
\hline $\mathrm{Hm}(\mathrm{m})$ & Heigth of mold (meter) & 0.078 \\
\hline $\operatorname{Dm}(\mathrm{m})$ & Dia of mold (meter) & $\mathbf{0 . 0 3 9}$ \\
\hline $\mathrm{w}: \mathrm{b}$ & Water to binder ratio & 1 \\
\hline$\gamma$ soil & Total unit weight of soil $(\mathrm{kg} / \mathrm{m} 3)$ & $1,549.00$ \\
\hline$\omega$ & Water content $(/ 100)$ & $79.00 \%$ \\
\hline Gs & Specific gravity of soil & 2.67 \\
\hline $\mathrm{Gb}$ & Specific gravity of binder & 3.15 \\
\hline ain-place & Binder dosage; Factor per total volume of mix $(\mathrm{kg} / \mathrm{m} 3)$ & 50 \\
\hline \multicolumn{3}{|c|}{ Calculations } \\
\hline$\alpha$ & Binder dosage; Factor per volume of wet soil $(\mathrm{kg} / \mathrm{m} 3)$ & 54 \\
\hline$\alpha \mathrm{w}(\%)$ & Binder content in percentage of soil solid & $6.19 \%$ \\
\hline $\operatorname{Vmix}(\mathrm{m} 3)$ & (\# of molds)( volume of mold) & 0.00009 \\
\hline$\gamma d$ soil & Dry unit weight of soil $(\mathrm{kg} / \mathrm{m} 3)$ & 865 \\
\hline $\mathrm{S}$ & Soil saturation & 0.989 \\
\hline VR & $\begin{array}{l}\text { Volume ratio expressed in terms of binder factor in-place for any } \\
\mathrm{S}\end{array}$ & 0.071 \\
\hline Vs & Volume of the dry soil (m3) & 0.0000275 \\
\hline Vsoil & Volume of wet soil (m3) & 0.00009 \\
\hline
\end{tabular}




\begin{tabular}{|c|c|c|}
\hline Ws & Weight of soil (wet) (kg) & 0.13 \\
\hline Wsoil & Weight of soil (dry) (kg) & 0.08 \\
\hline $\mathrm{Wb}$ & Weight of the binder $(\mathrm{kg})$ & 0.005 \\
\hline Ww,slurry & $\begin{array}{l}\text { Weight of water in the slurry for wet mixing (kg) (water added) } \\
(\mathrm{kg})\end{array}$ & 0.005 \\
\hline $\mathrm{Vb}$ & Volume of the binder (m3) & 0.000001 \\
\hline$\gamma d$, slurry & Dry unit weight of the slurry (Wb/Vslurry) & 759 \\
\hline Vw,slurry & Volume of water in the slurry for wet mixing (m3) & 0.00000 \\
\hline Vw,mix & Volume of water in the mixture & 0.000064 \\
\hline Vw,s & Volume of water in the soil (m3) & 0.000060 \\
\hline $\mathrm{WW}_{\mathrm{w}, \mathrm{mix}}$ & Weight of water in the mixture (m3) & 0.06 \\
\hline Vslurry & Volume of slurry before mixing ( $\mathrm{Vb}+\mathrm{V}_{\mathrm{w}}$,slurry) (m3) & 0.000006 \\
\hline Vmix & Volume of the mixture $\left(\mathrm{Vs}+\mathrm{Vb}+\mathrm{V}_{\mathrm{w}, \mathrm{mix}}\right)(\mathrm{m} 3)$ & 0.00009 \\
\hline Wmix & Weight of the mixture (Ws $+\mathrm{Wb}+\mathrm{Ww}$,mix) $(\mathrm{m} 3)$ & 0.1441 \\
\hline \multicolumn{3}{|c|}{ Results } \\
\hline $\mathrm{w}: \mathrm{b}$ & Water to binder ratio & 1 \\
\hline wT:b & Total water-to-binder ratio of mix (wT:b) & 13.77 \\
\hline VR & $\begin{array}{l}\text { Volume ratio expressed in terms of binder factor in-place for any } \\
\text { S }\end{array}$ & 0.07 \\
\hline ain-place & Binder dosage; Factor per total volume of mix $(\mathrm{kg} / \mathrm{m} 3)$ & 50 \\
\hline$\alpha$ & Binder dosage; Factor per volume of wet soil $(\mathrm{kg} / \mathrm{m} 3)$ & 54 \\
\hline$\alpha \mathrm{w}(\%)$ & Binder content in percentage of soil solid & $6.19 \%$ \\
\hline Wsoil & Weight of the soil to be used (g) & 134.83 \\
\hline $\mathrm{Wb}$ & Weight of the binder $(\mathrm{g})$ & 4.66 \\
\hline Ww,slurry & Weight of water in the slurry for wet mixing (g) & 4.66 \\
\hline
\end{tabular}


Appendix B - Leaching process 


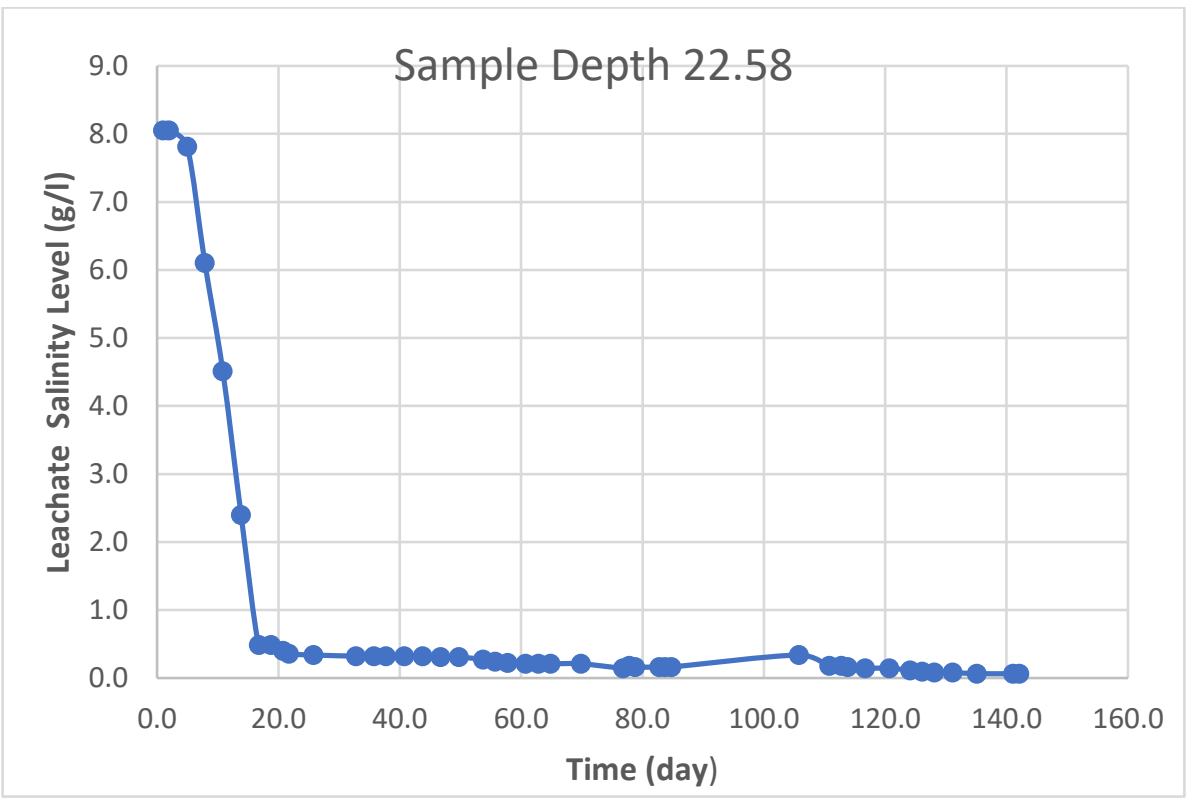



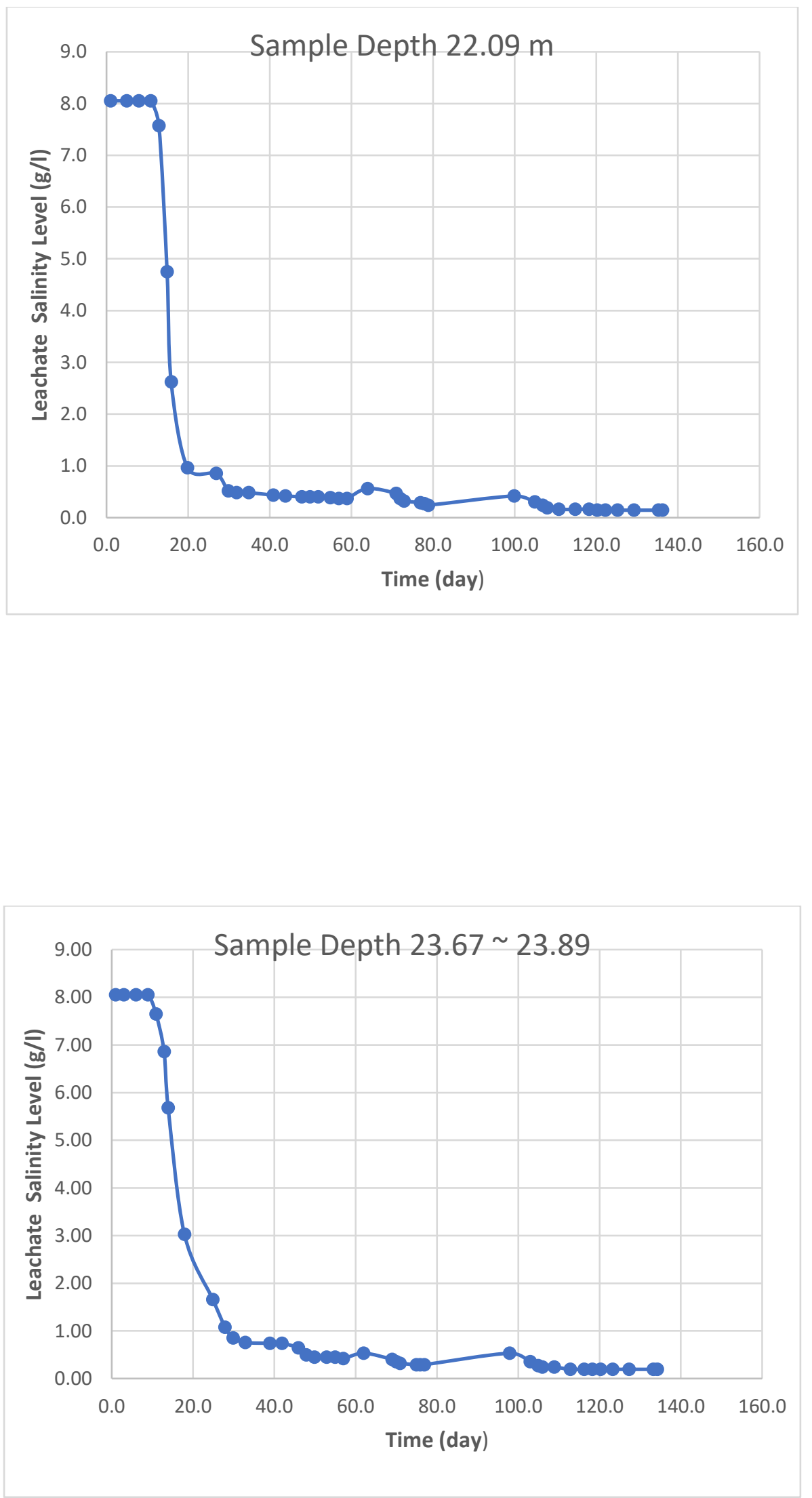


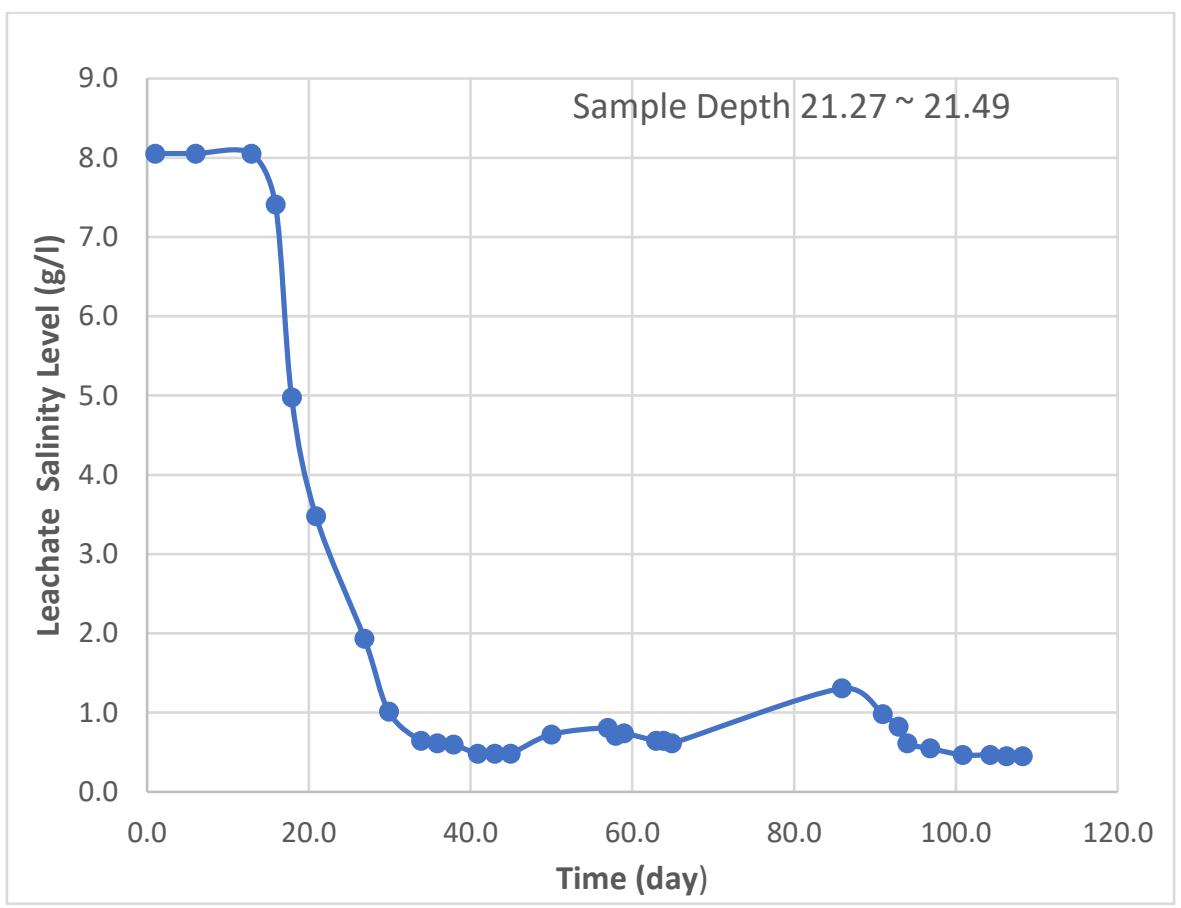




\section{Appendix C- Triaxial Test Results}




\section{C-1 Triaxial test result for the unleached untreated Soil sample}

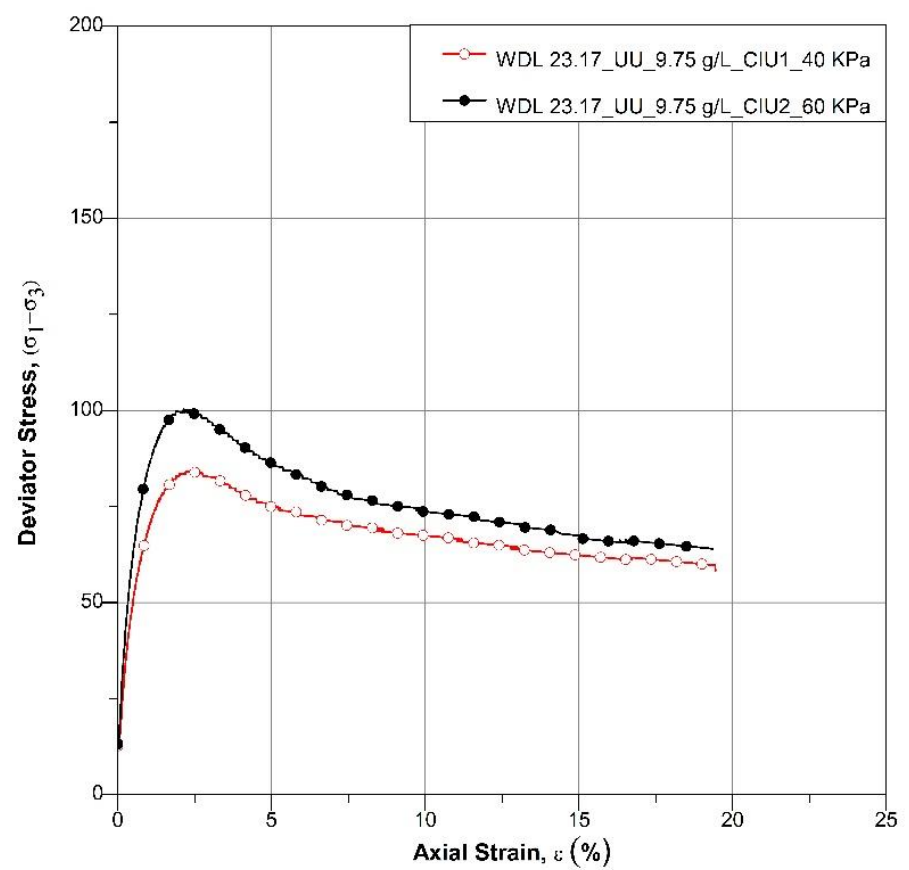



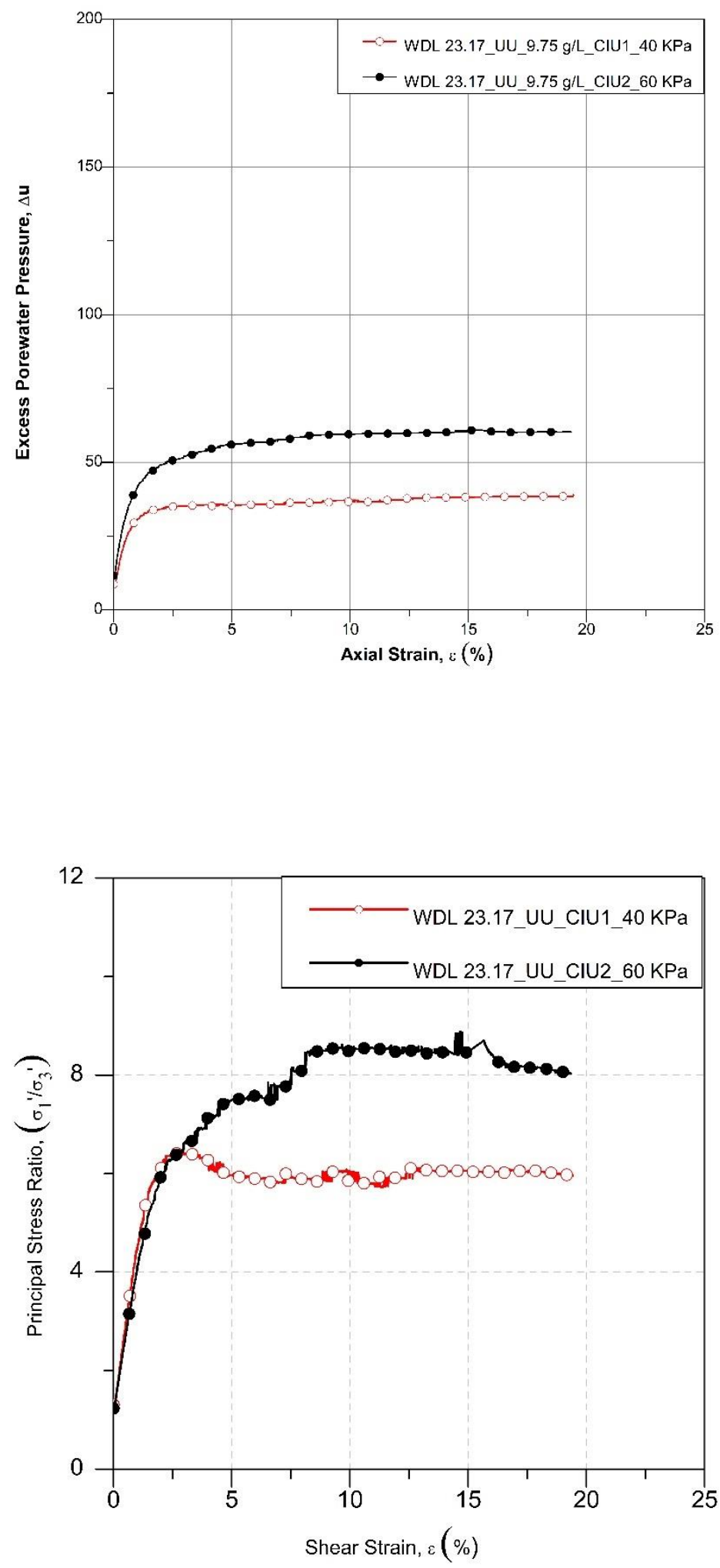


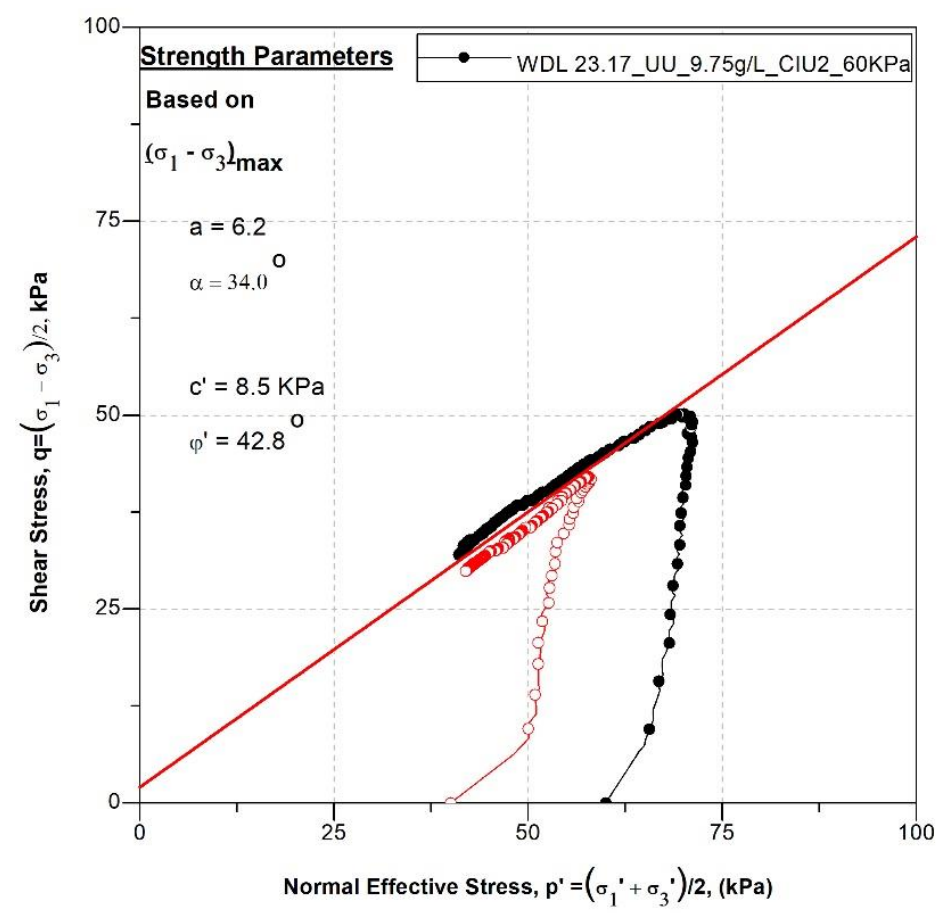

C-2 Triaxial test results for leached soil $(2.75 \mathrm{~g} / \mathrm{L})$ sample

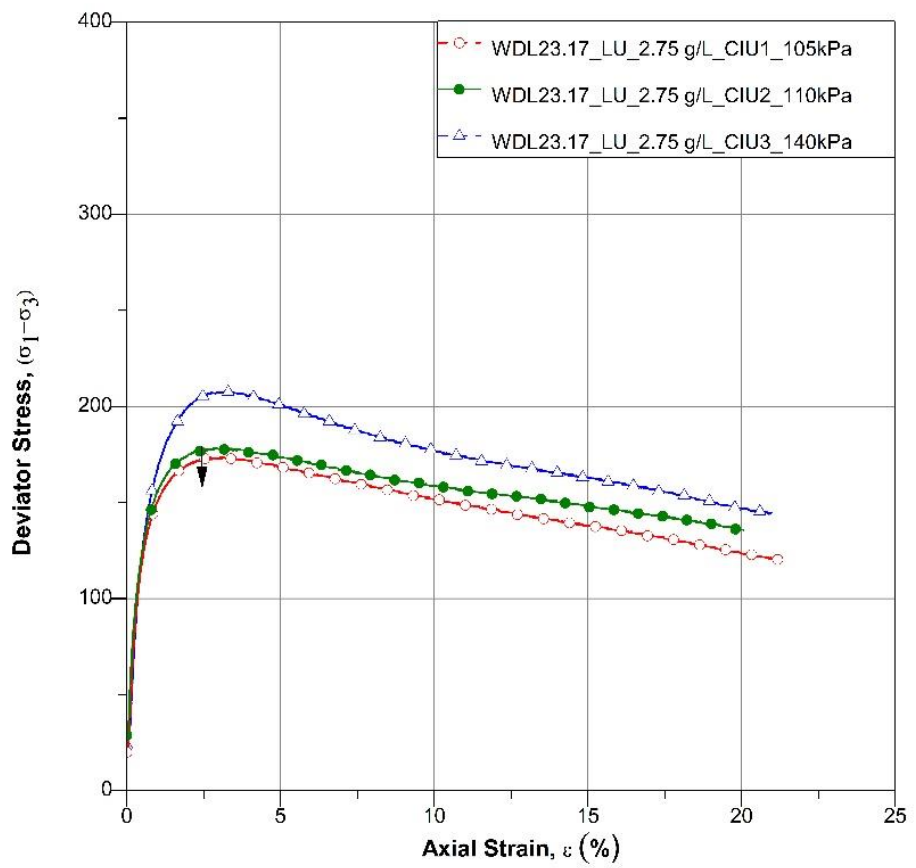



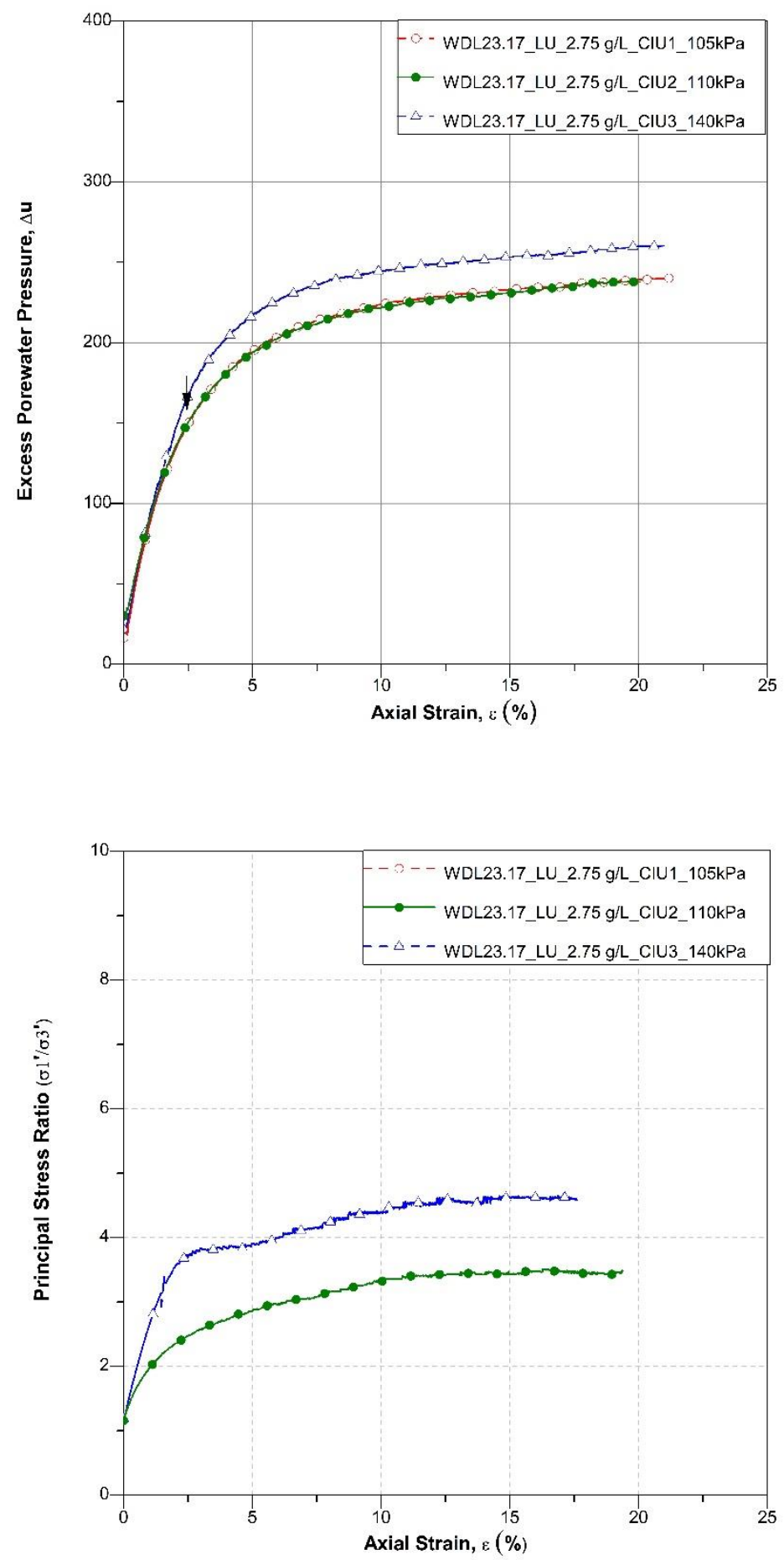


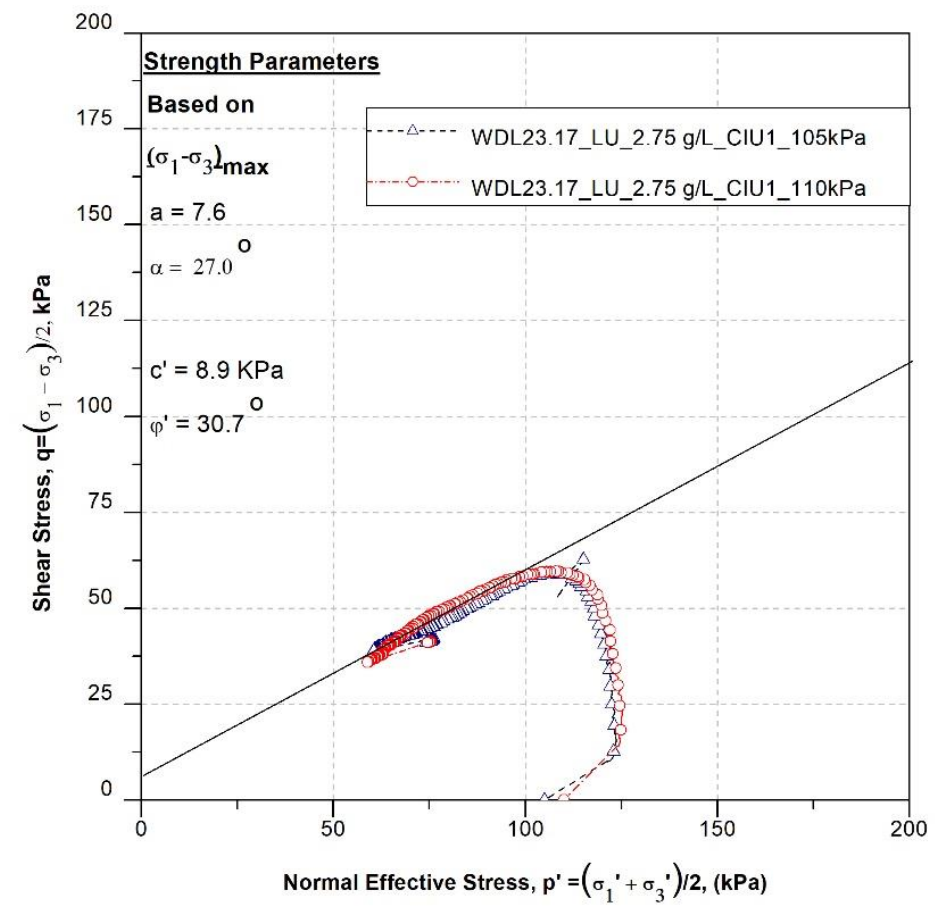

C-3 Triaxial test results for leached soil (1.03 g/L) sample

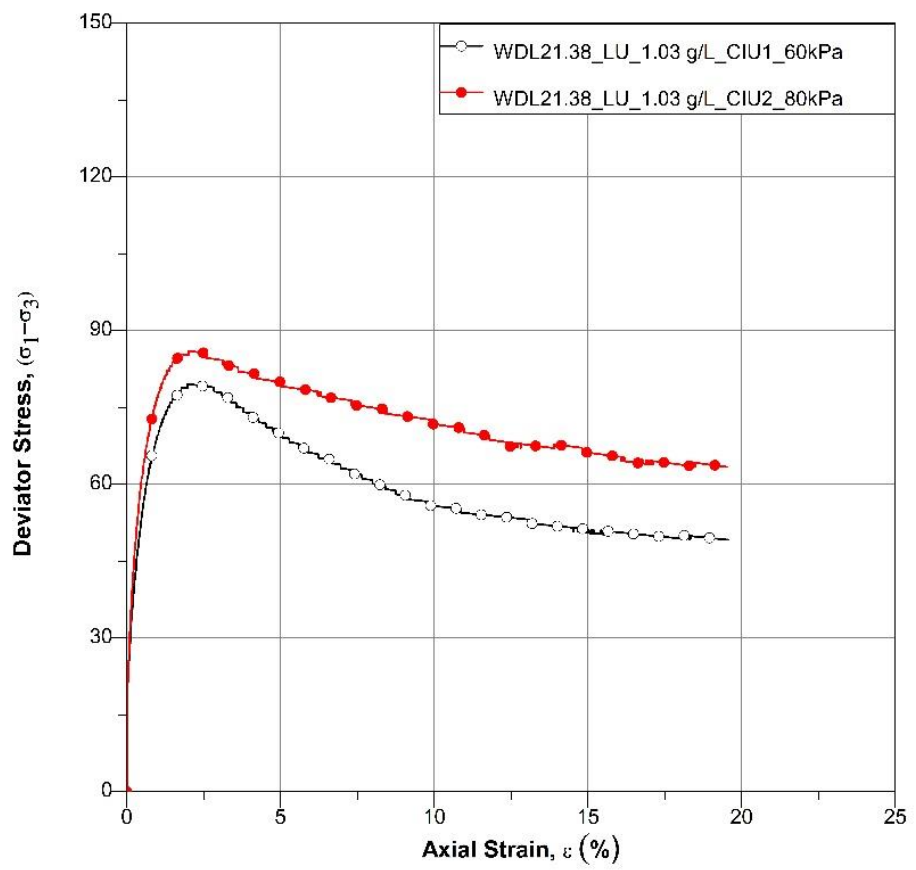



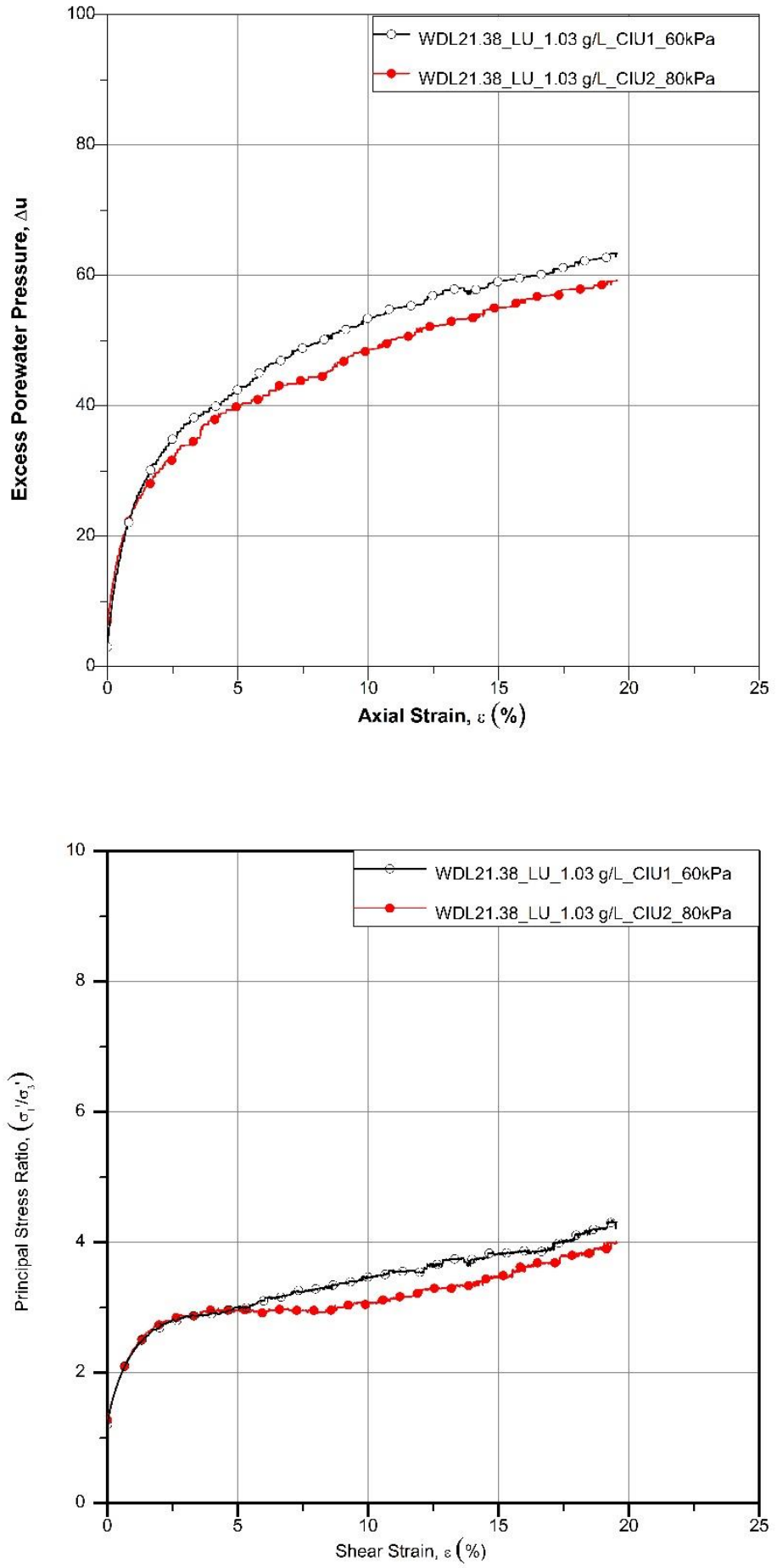


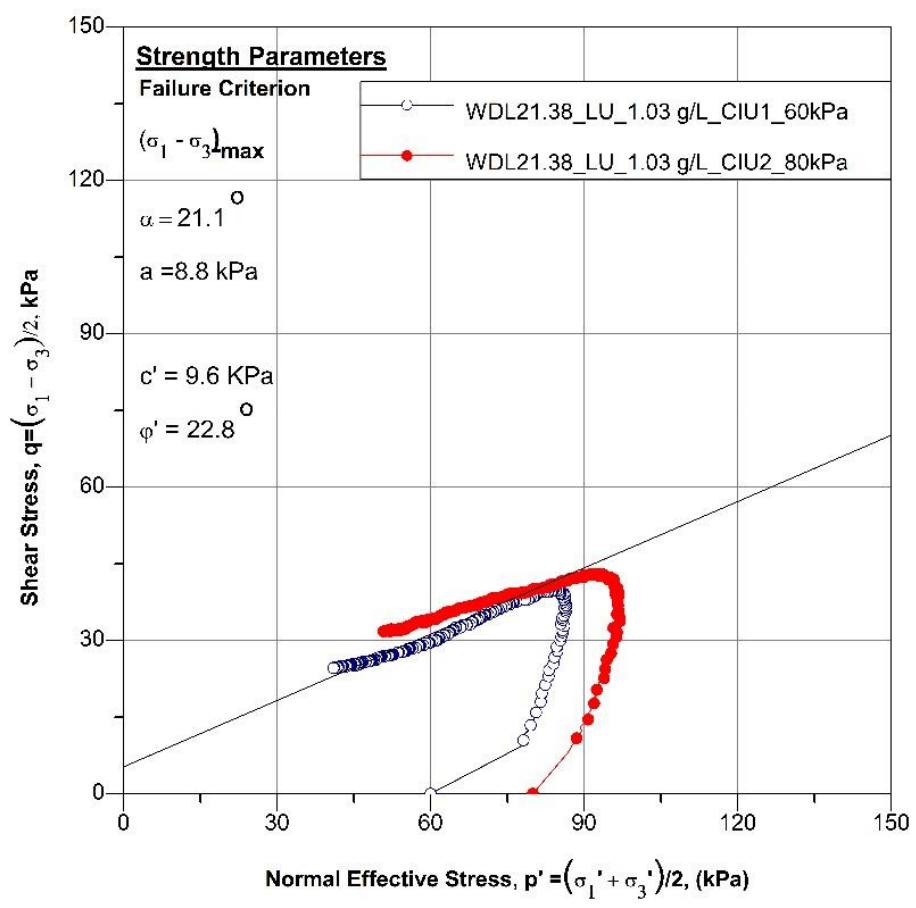

C-4 Triaxial test result of unleached treated 7-day cured soil sample at $50 \mathrm{~kg} / \mathrm{m}^{3} \mathrm{dosage}$ 

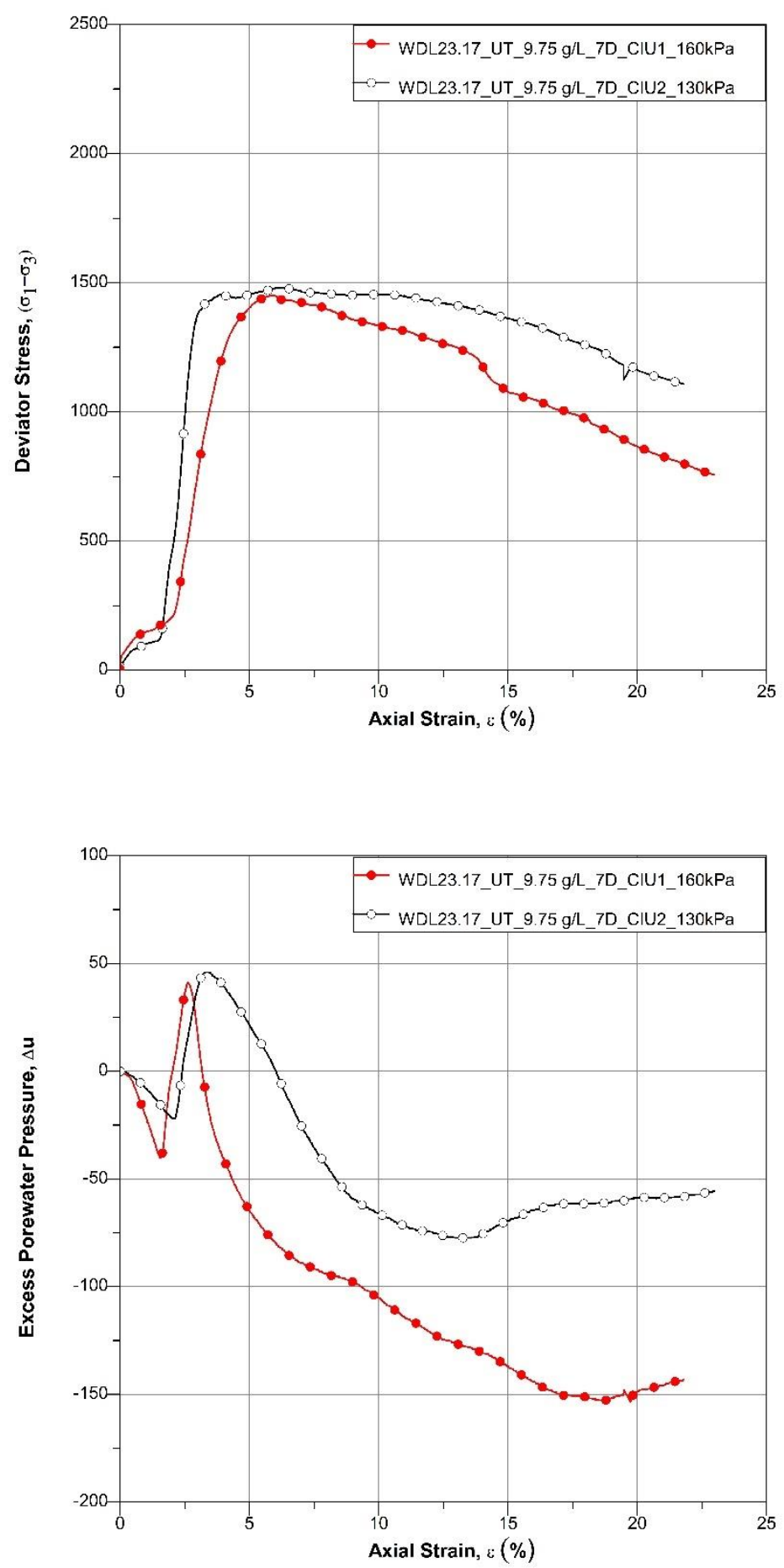

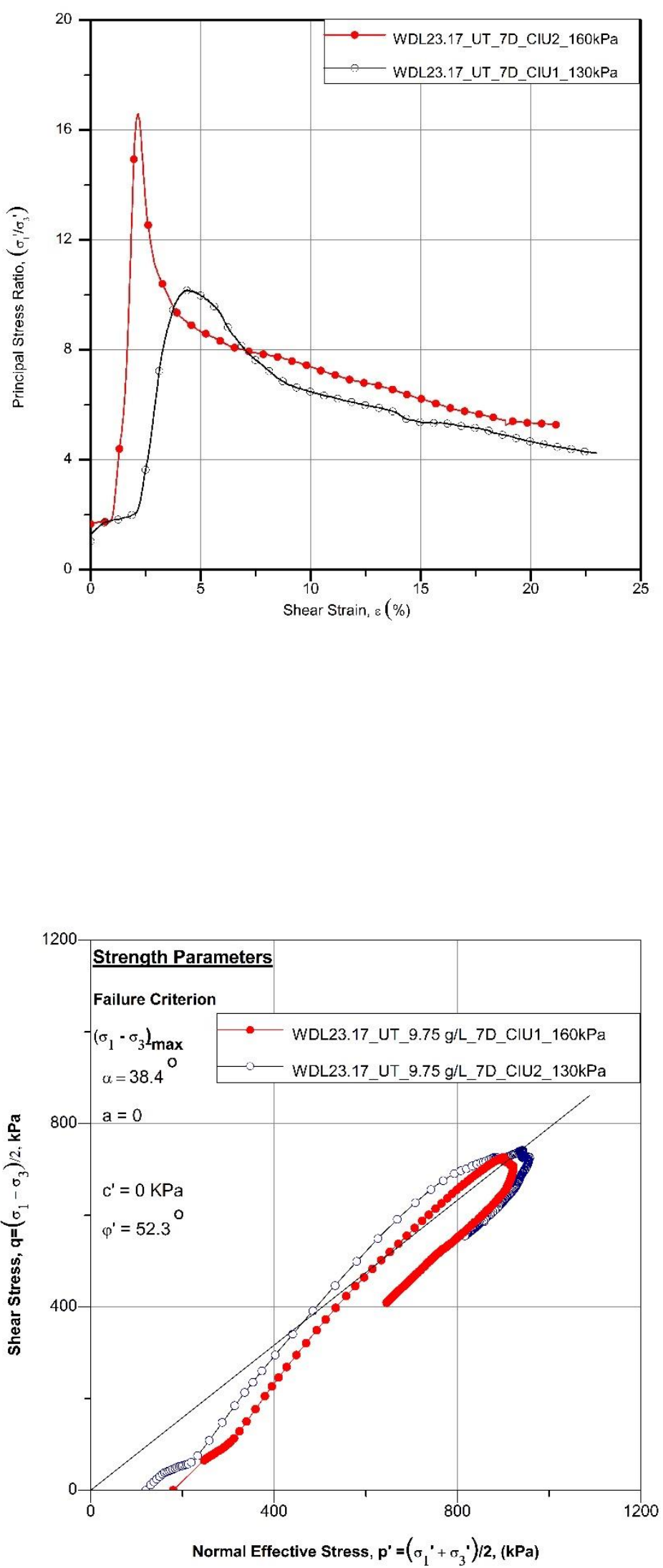
C-5 Triaxial test result of leached treated 7-day cured soil sample at $50 \mathrm{~kg} / \mathrm{m}^{3}$ dosage
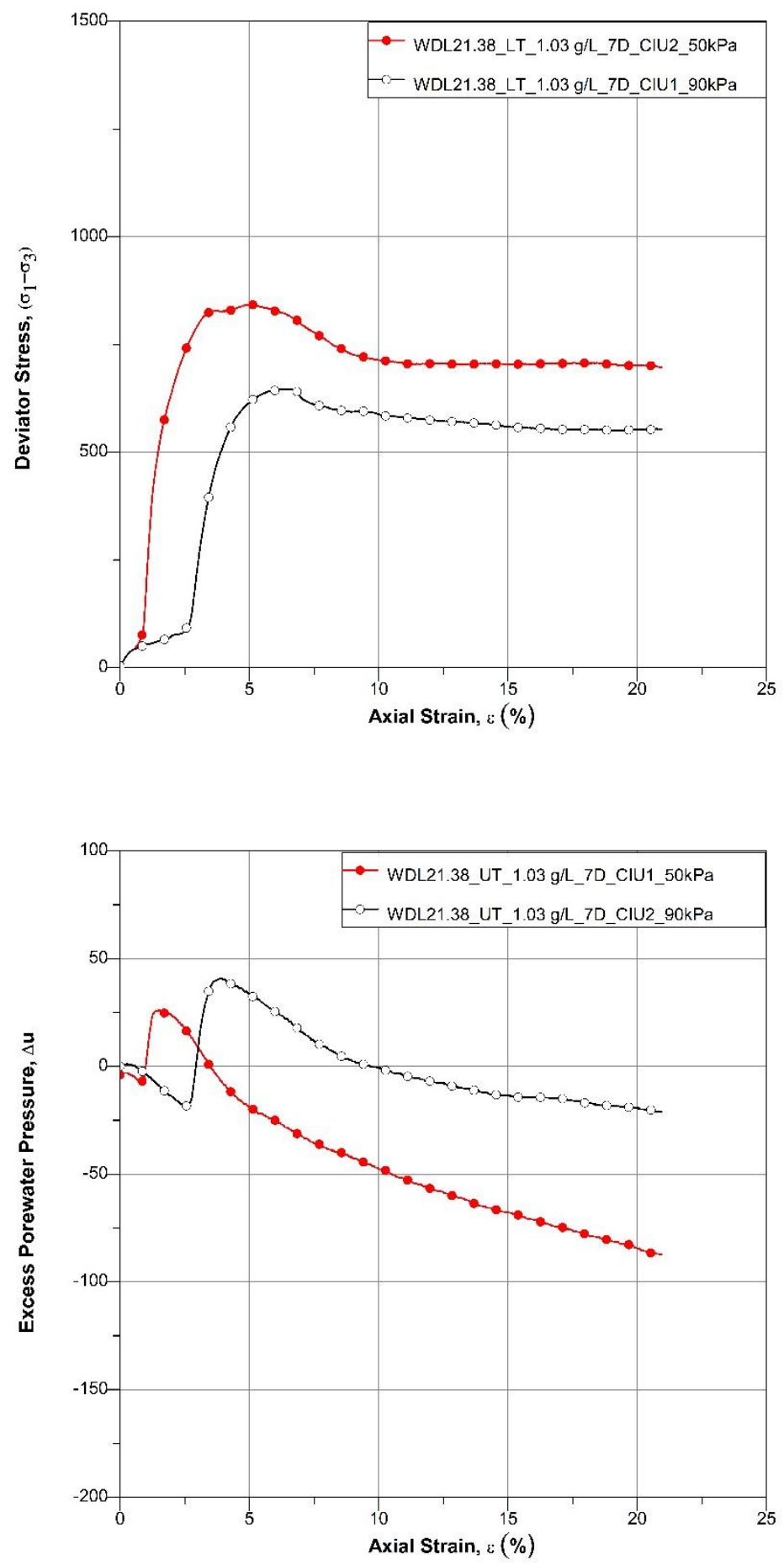


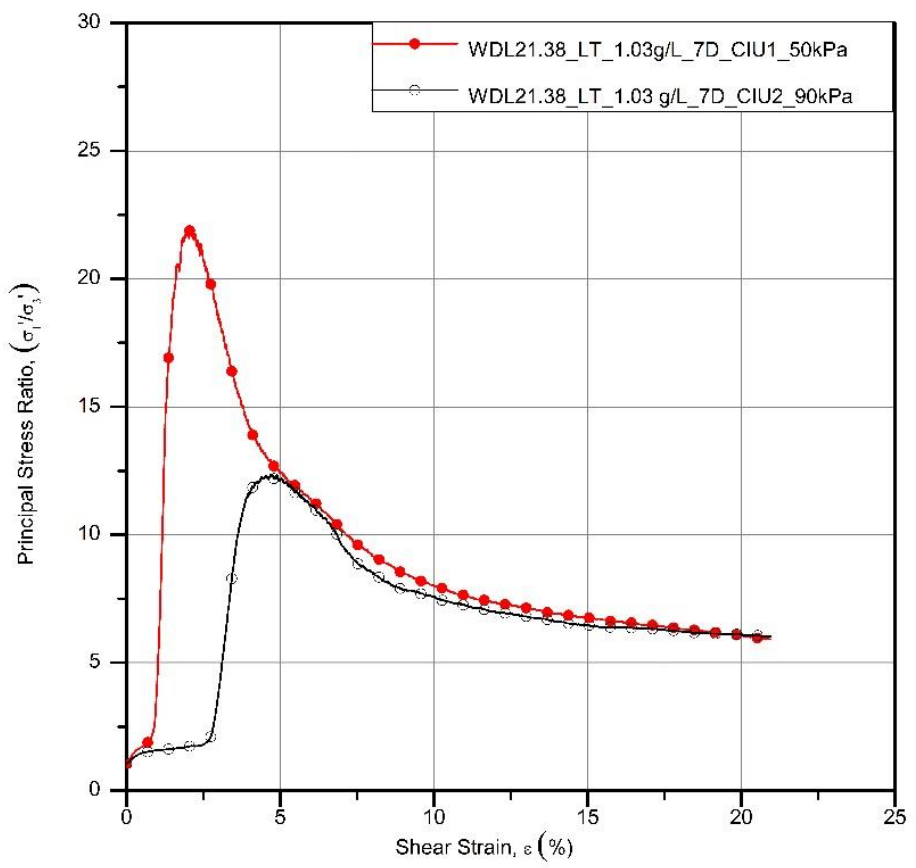




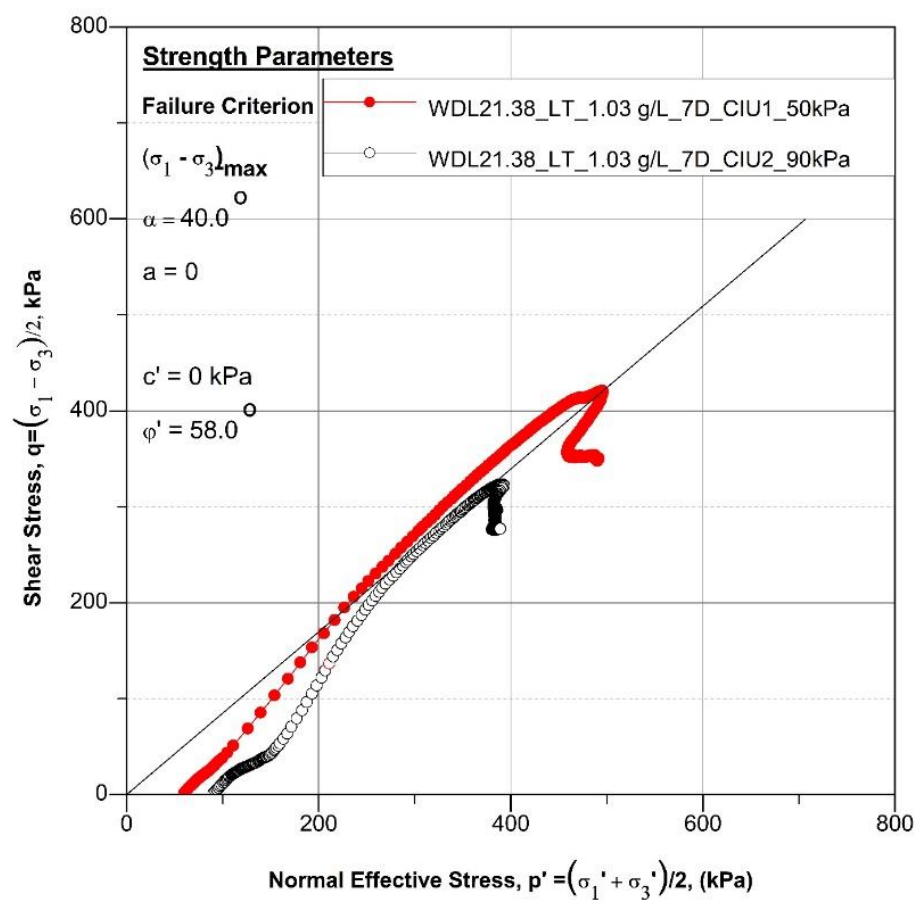




\section{Appendix D- CRS Test Results}




\section{D-1 CRS test result of leached remoulded soil sample}
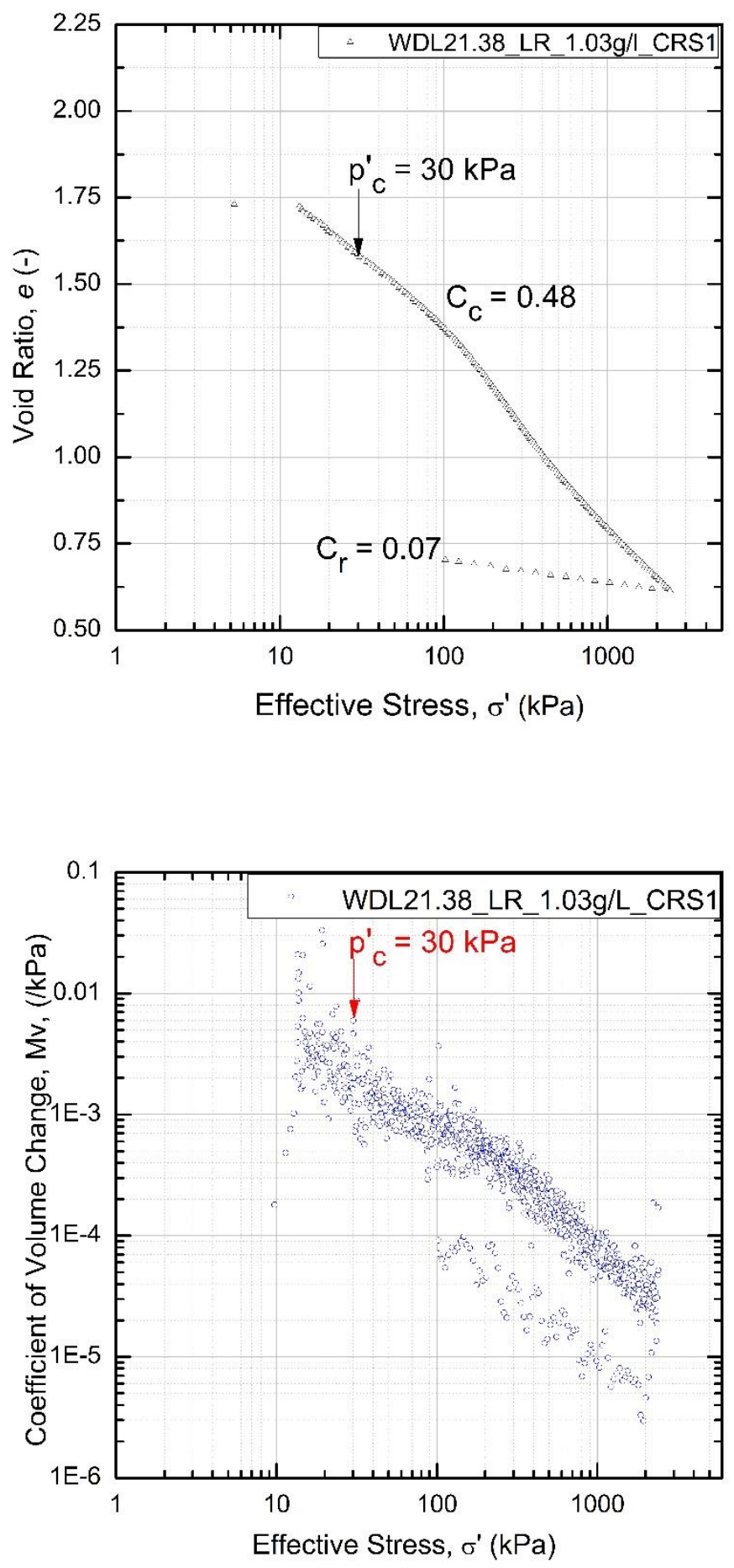

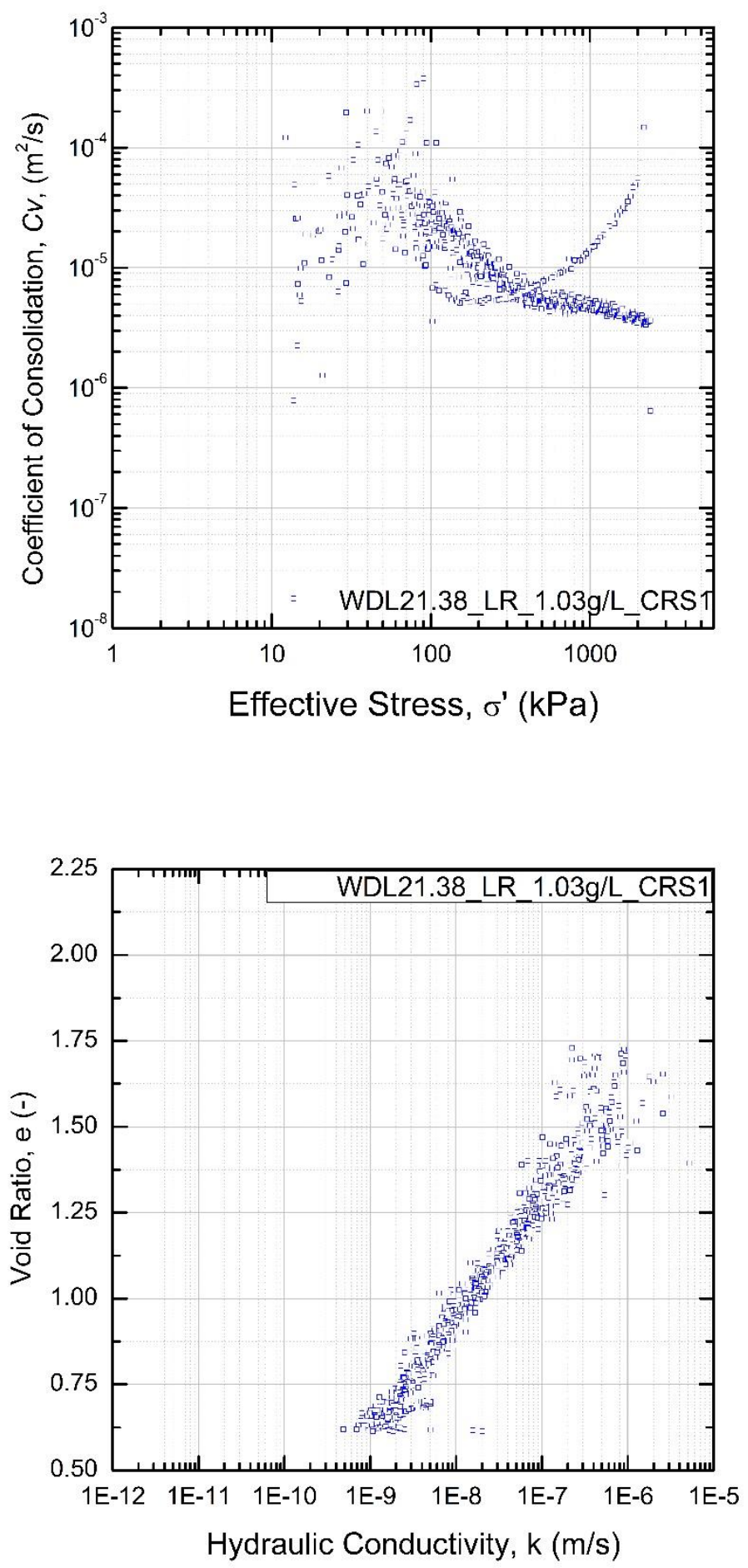


\section{D-2 CRS test result of Native (Unleached Untreated) soil sample}

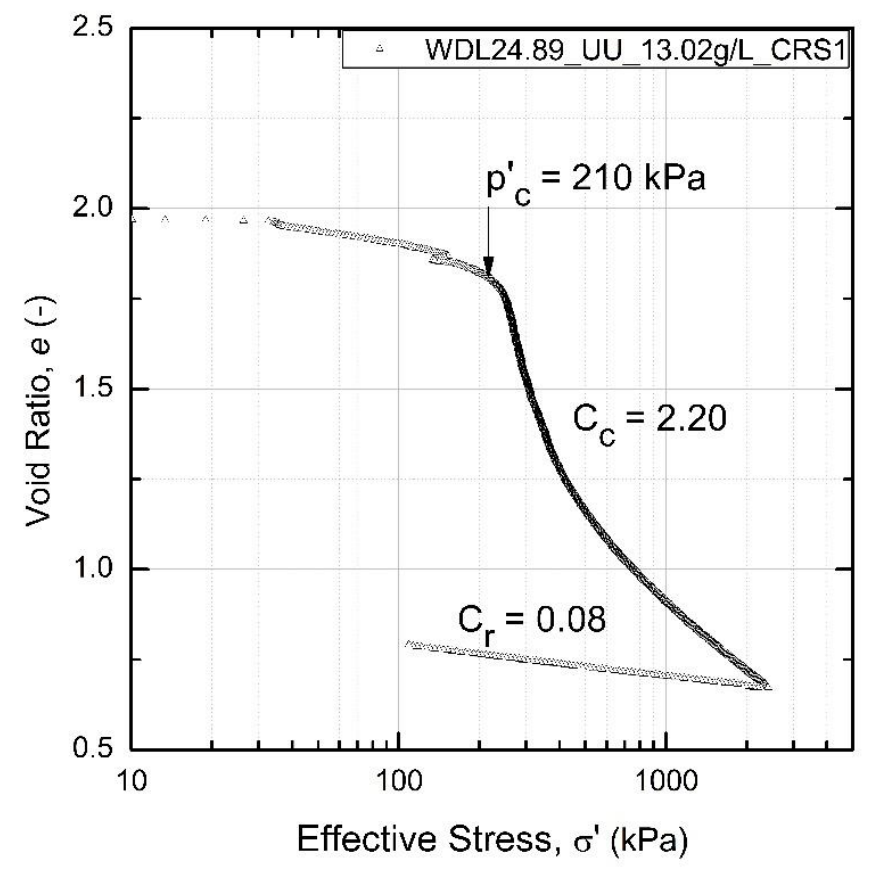



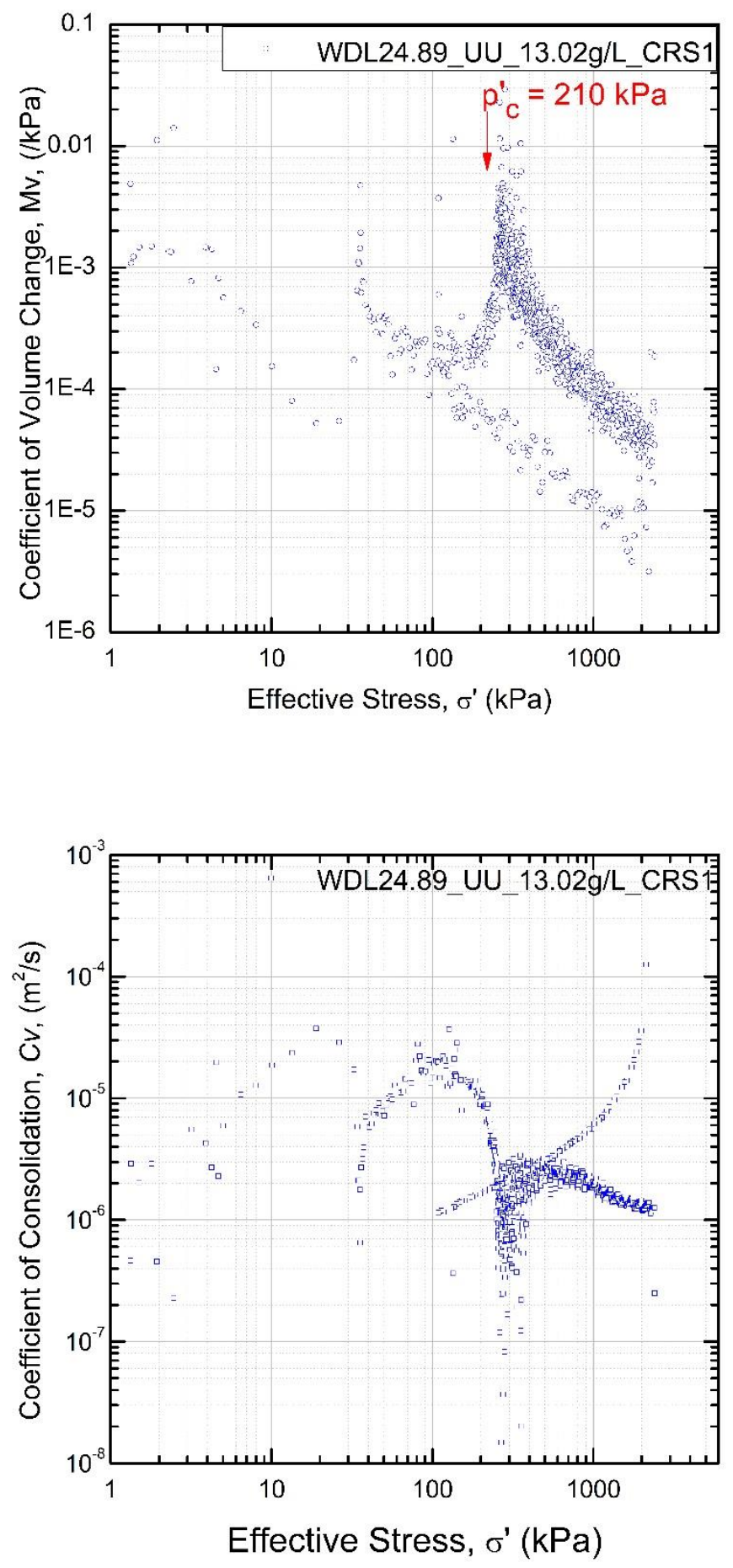


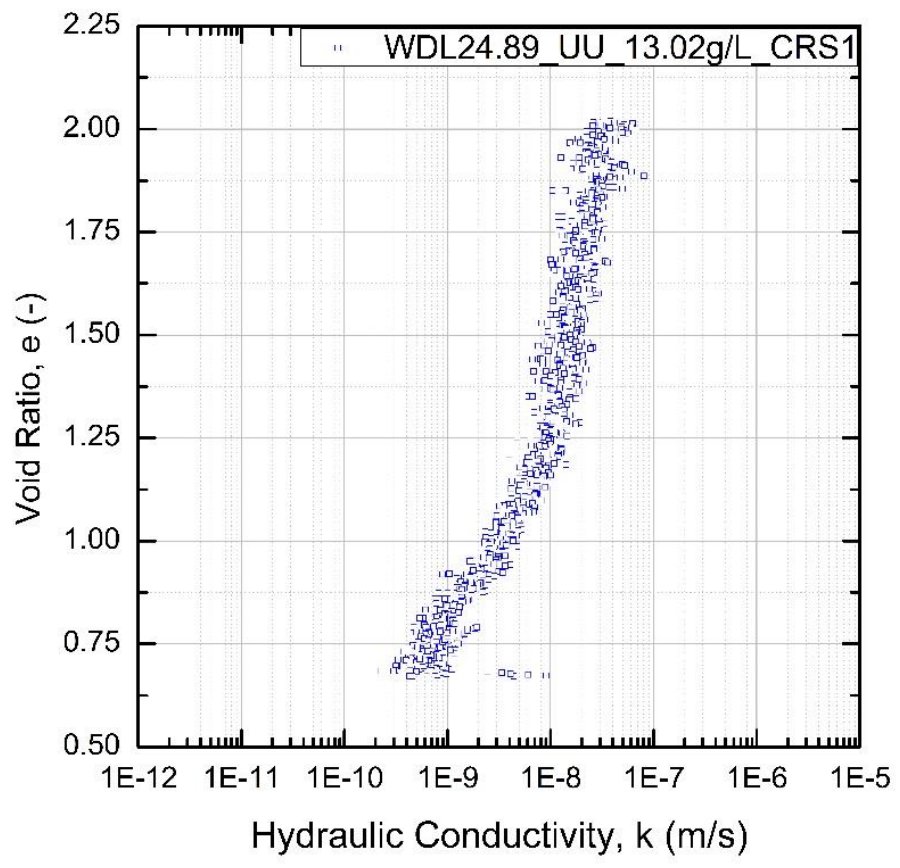

D-3 CRS test result of Leached Untreated soil sample 

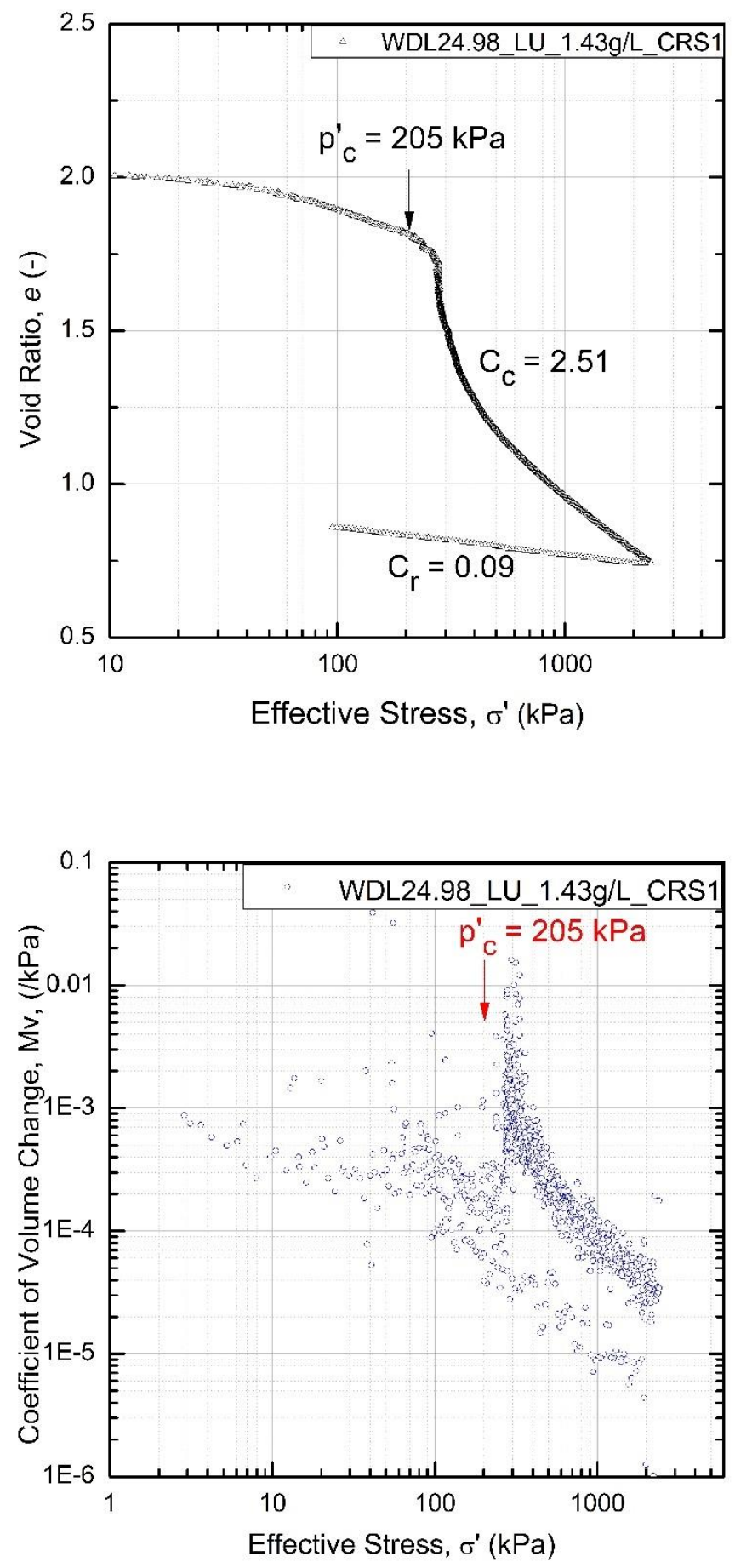

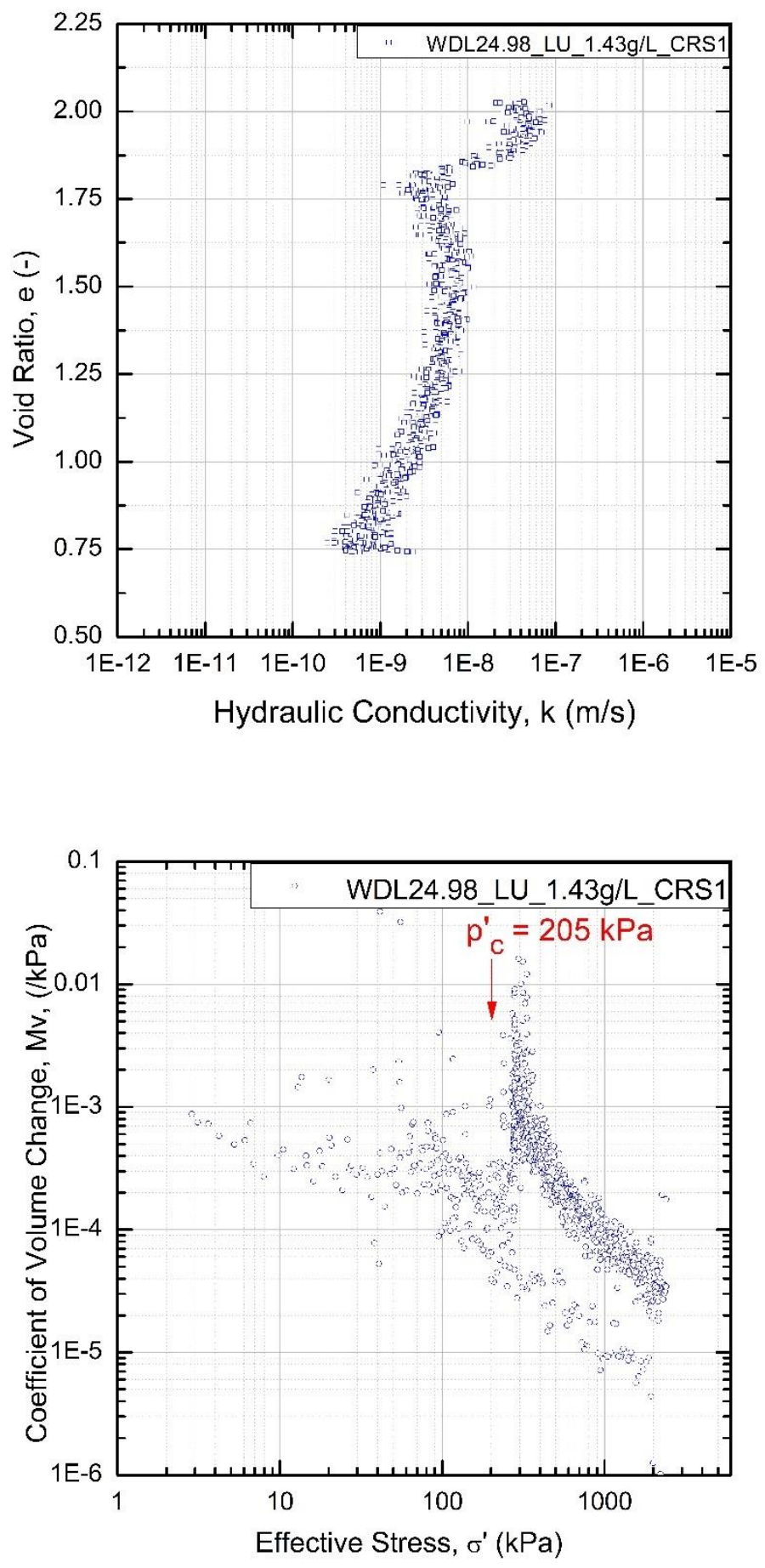

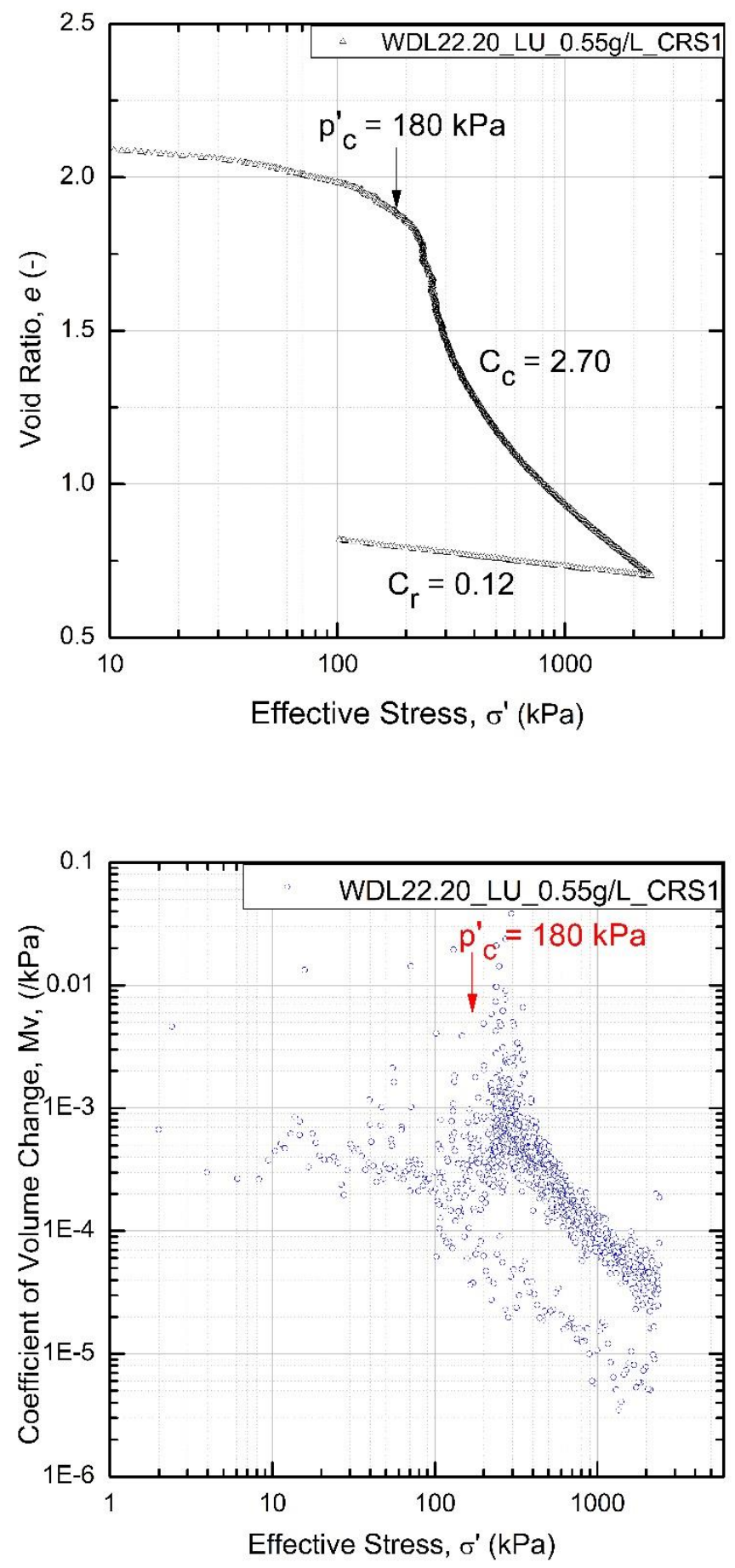

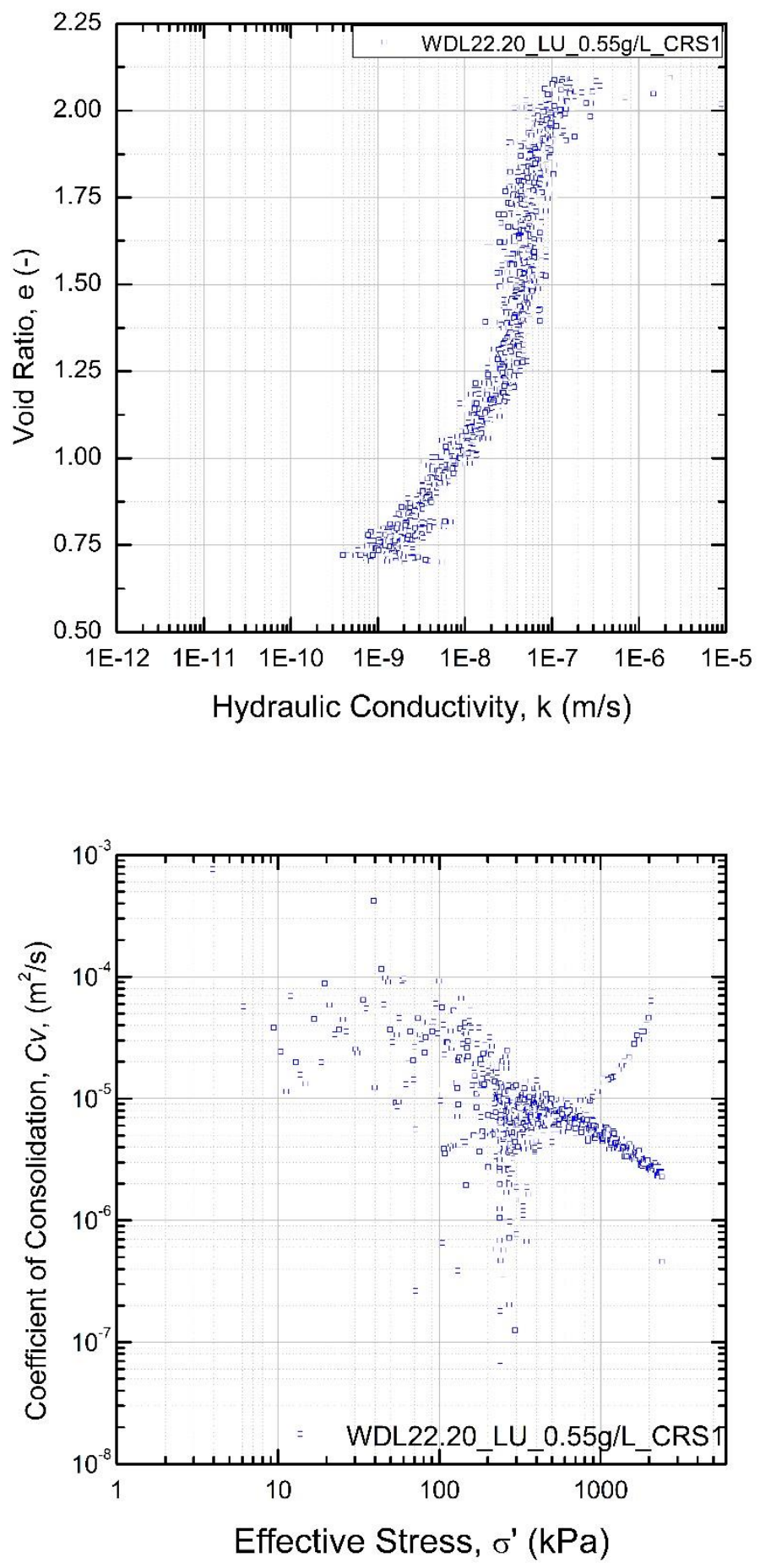

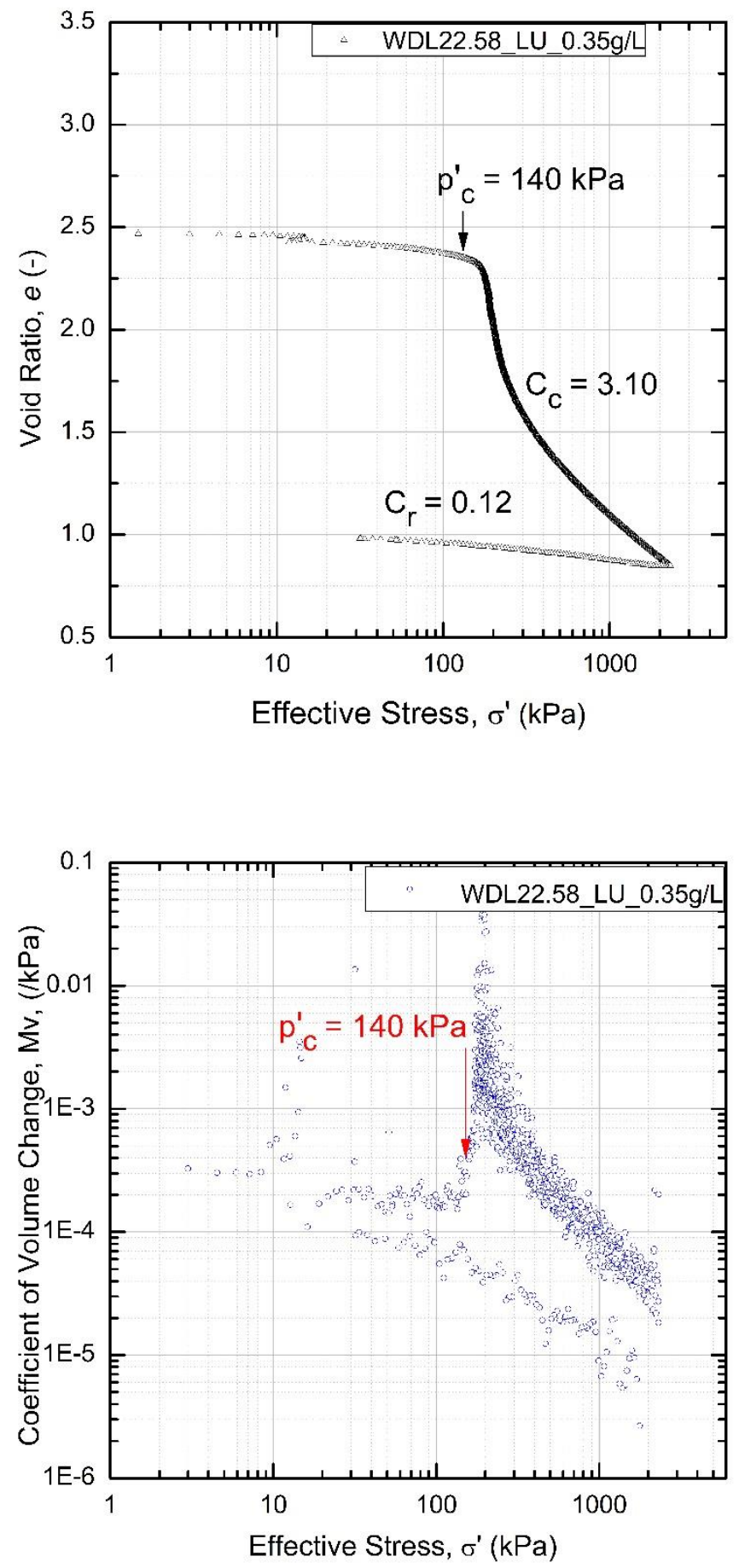

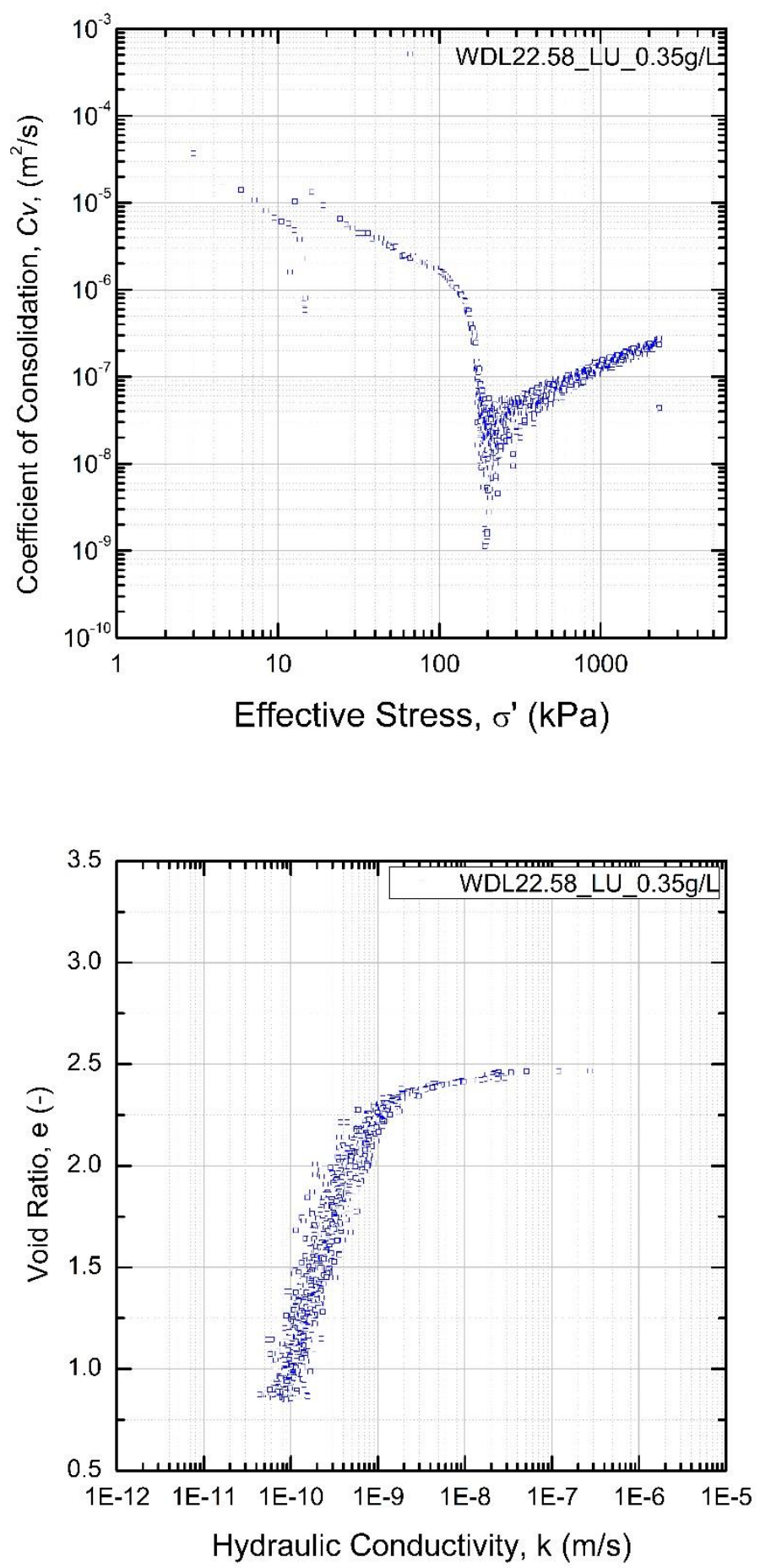


\section{D-4 CRS test result of unleached treated soil sample}

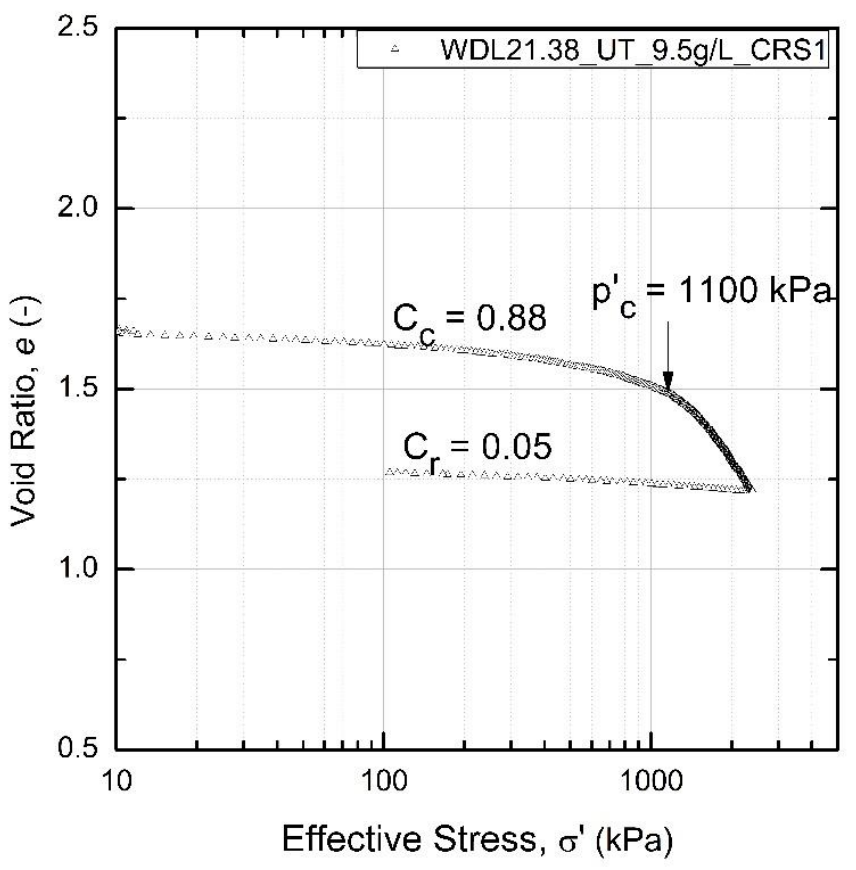



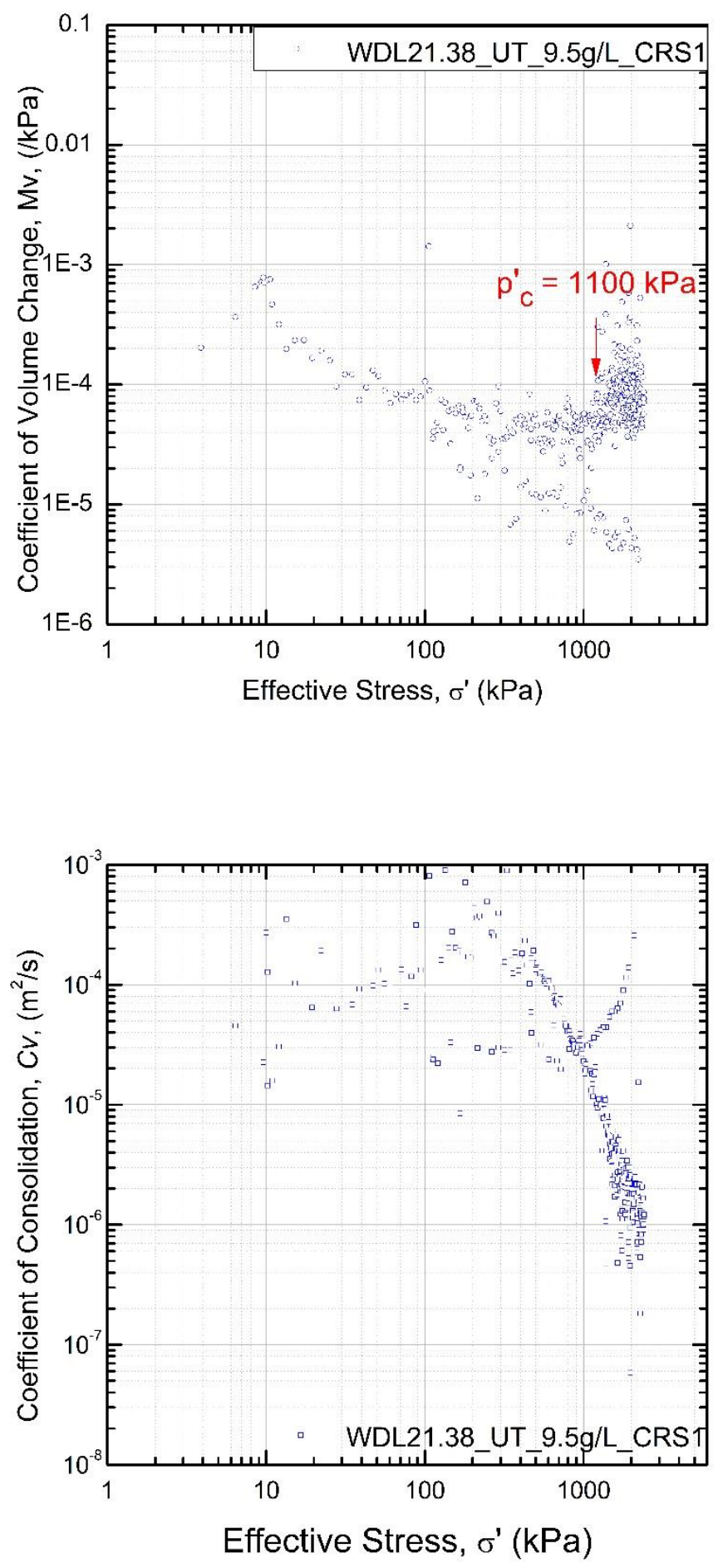


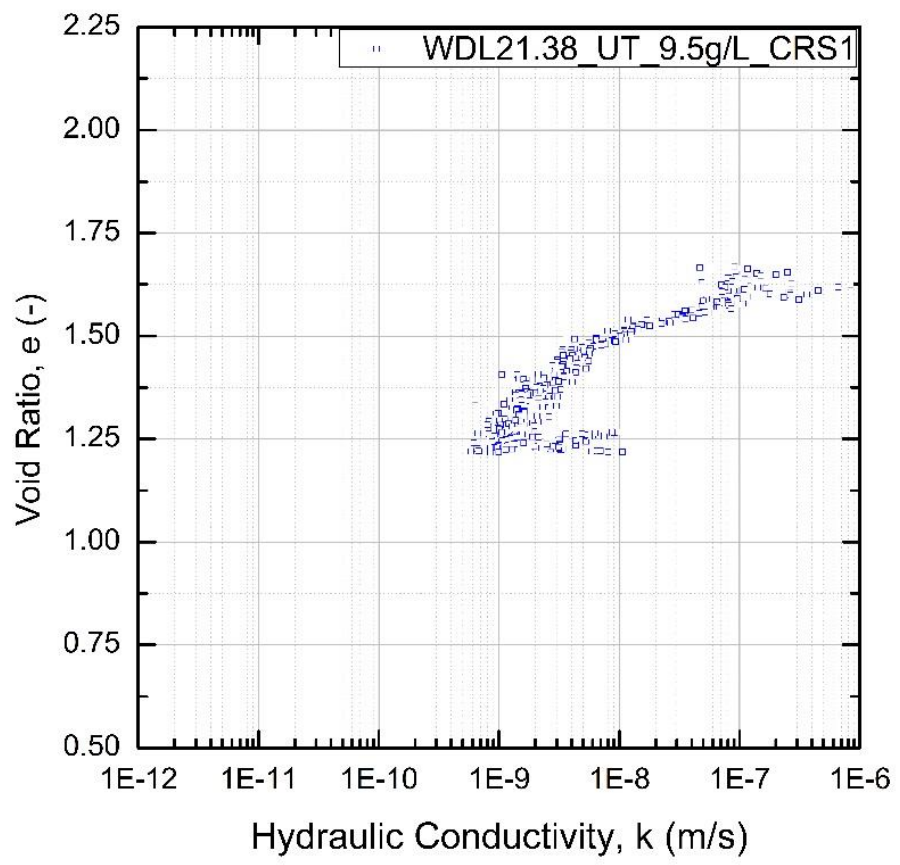

D-5 CRS test result of Leached treated soil sample 

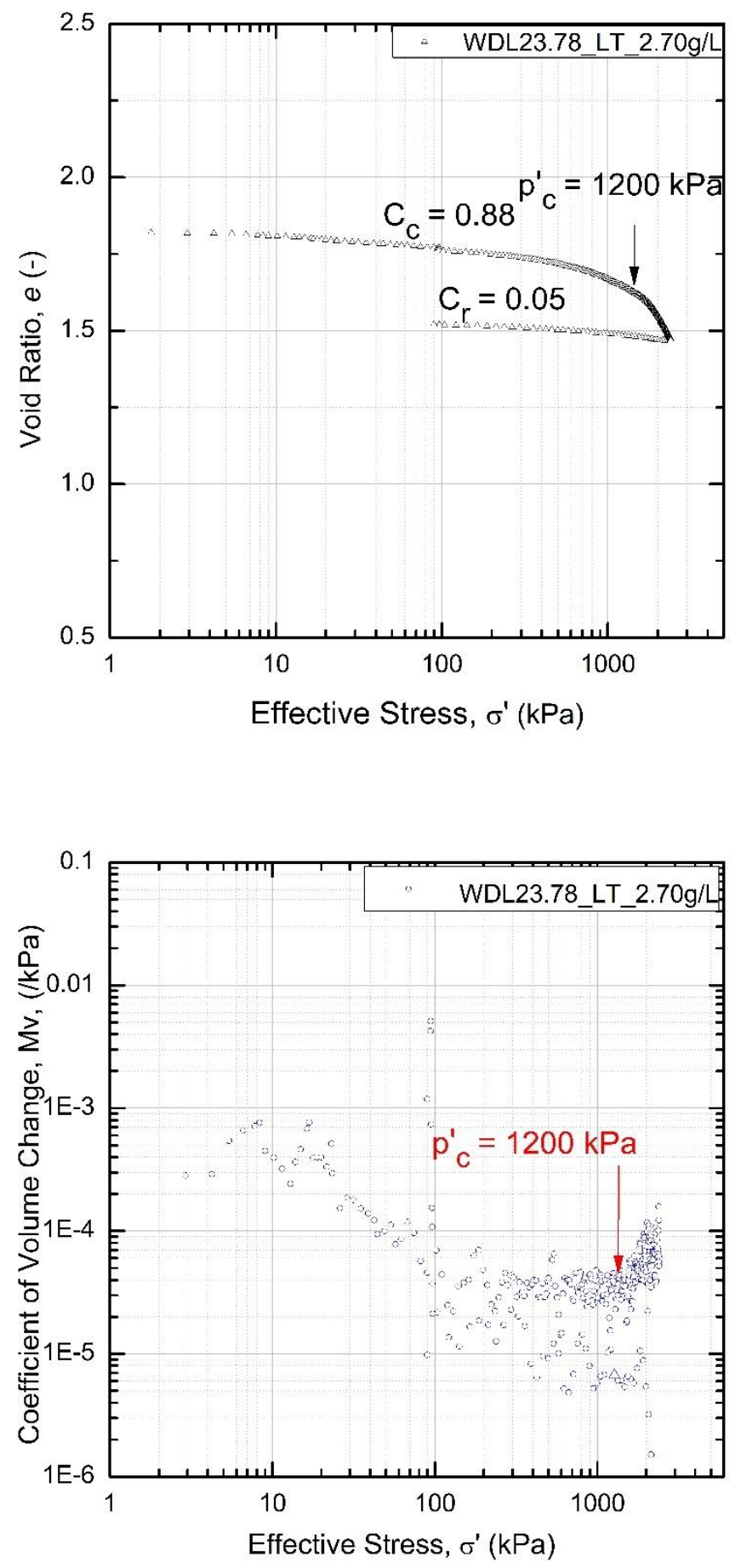

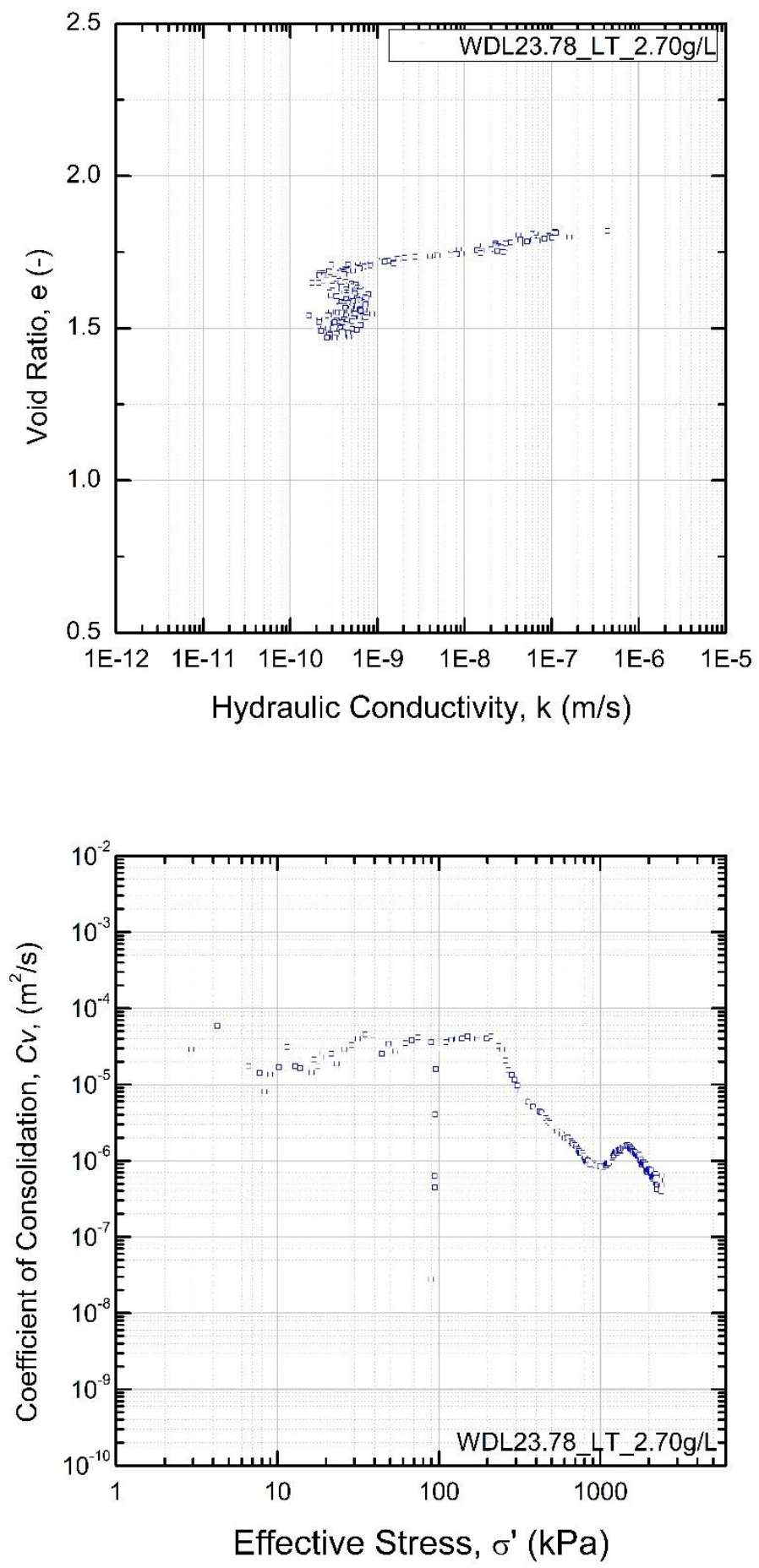

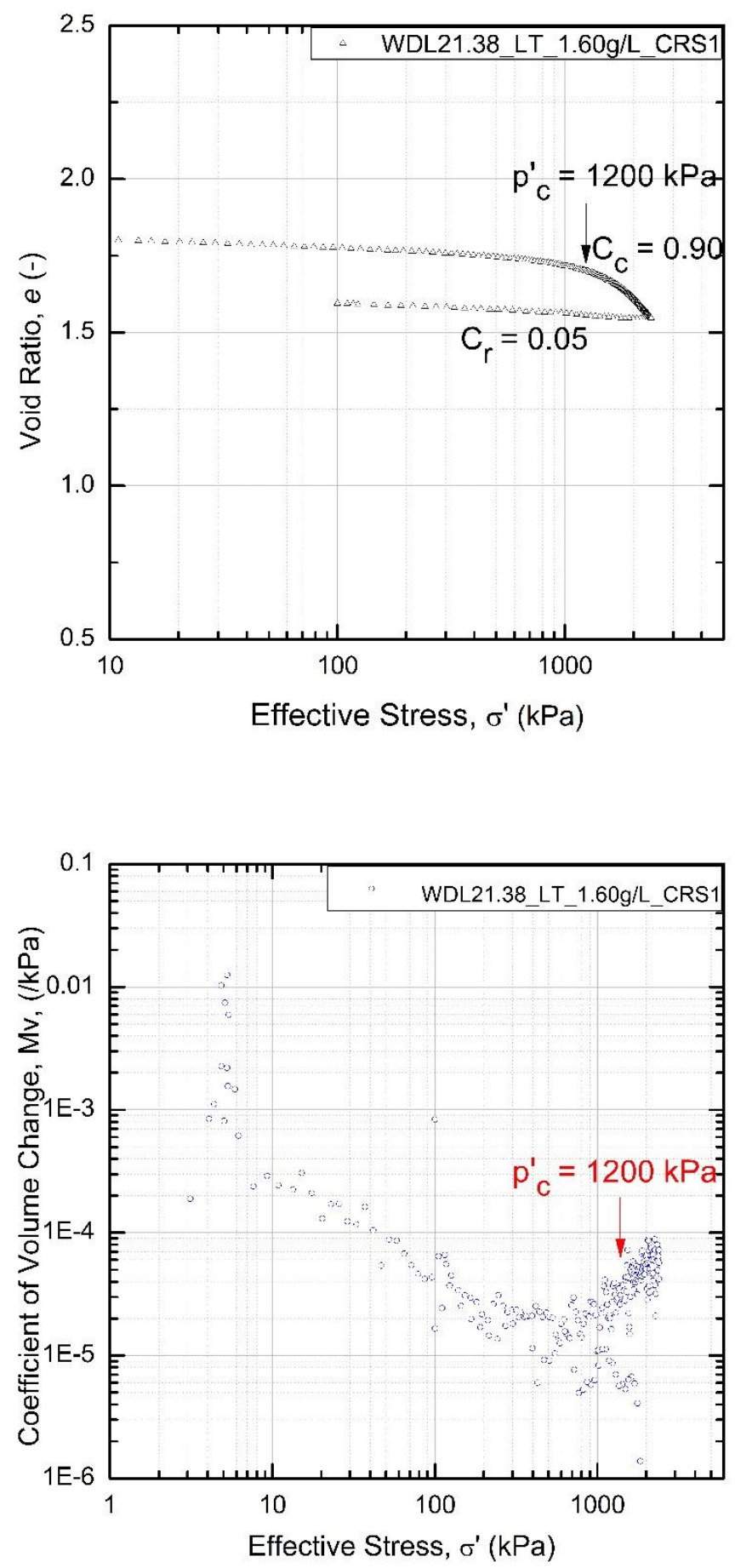

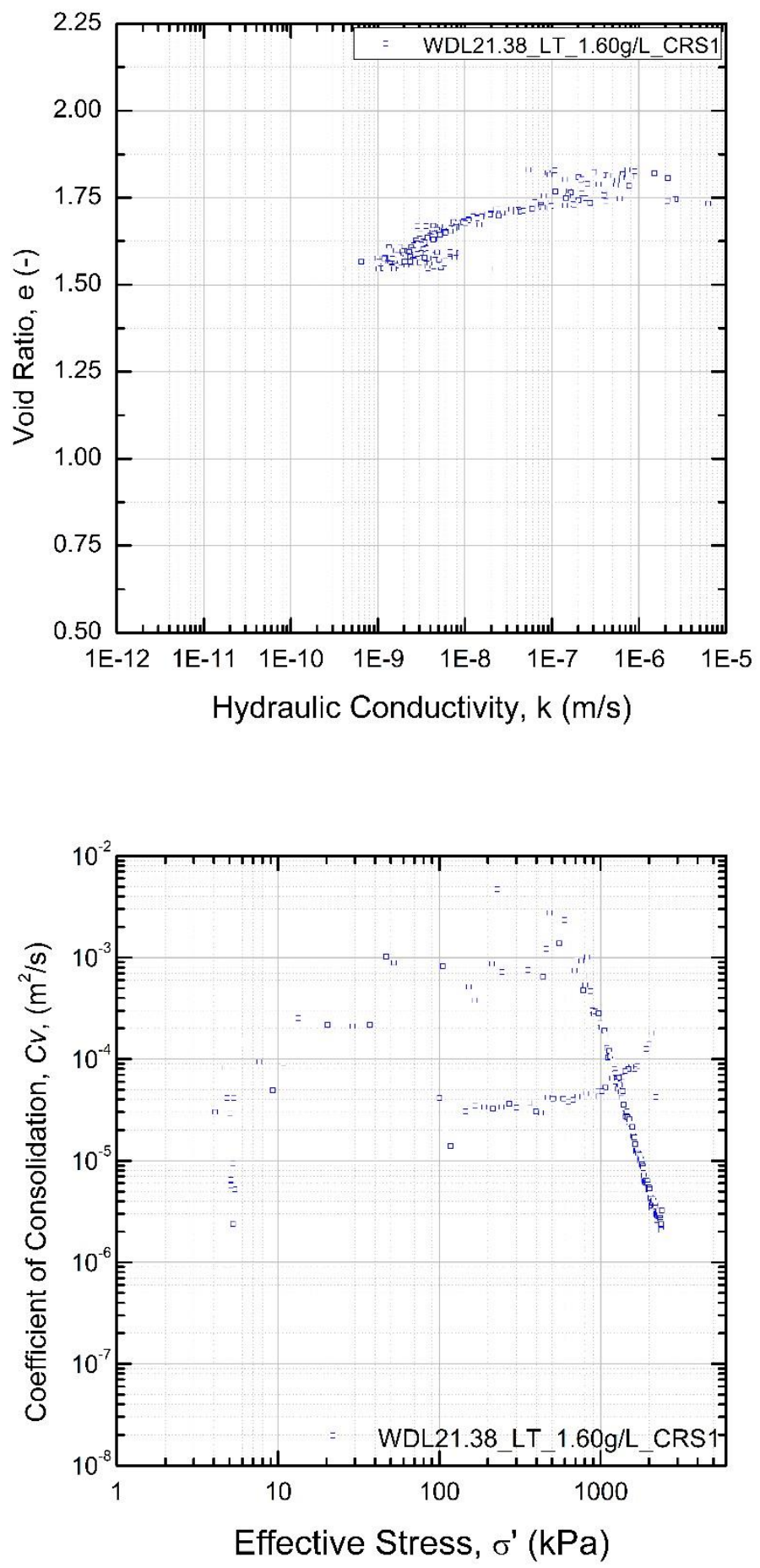

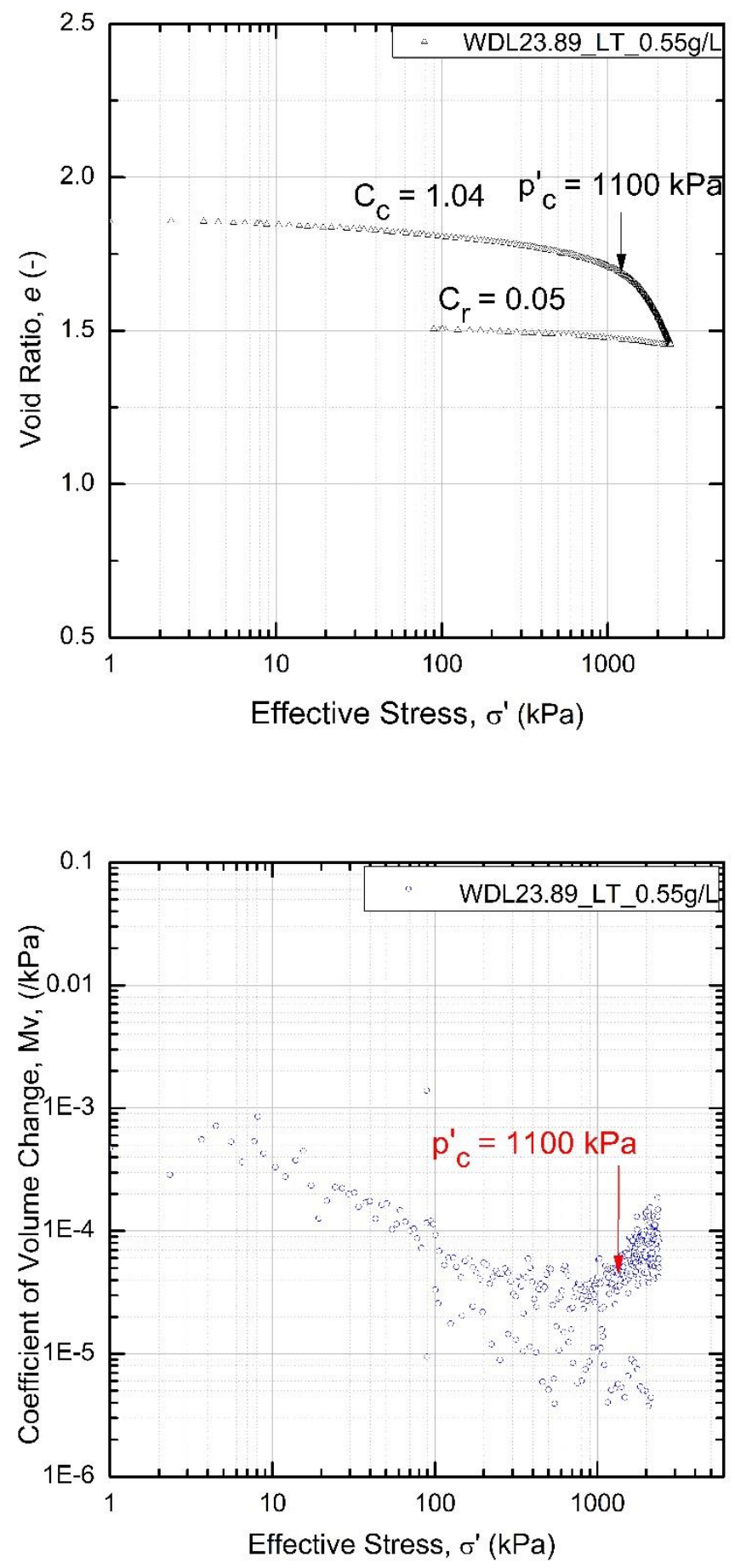

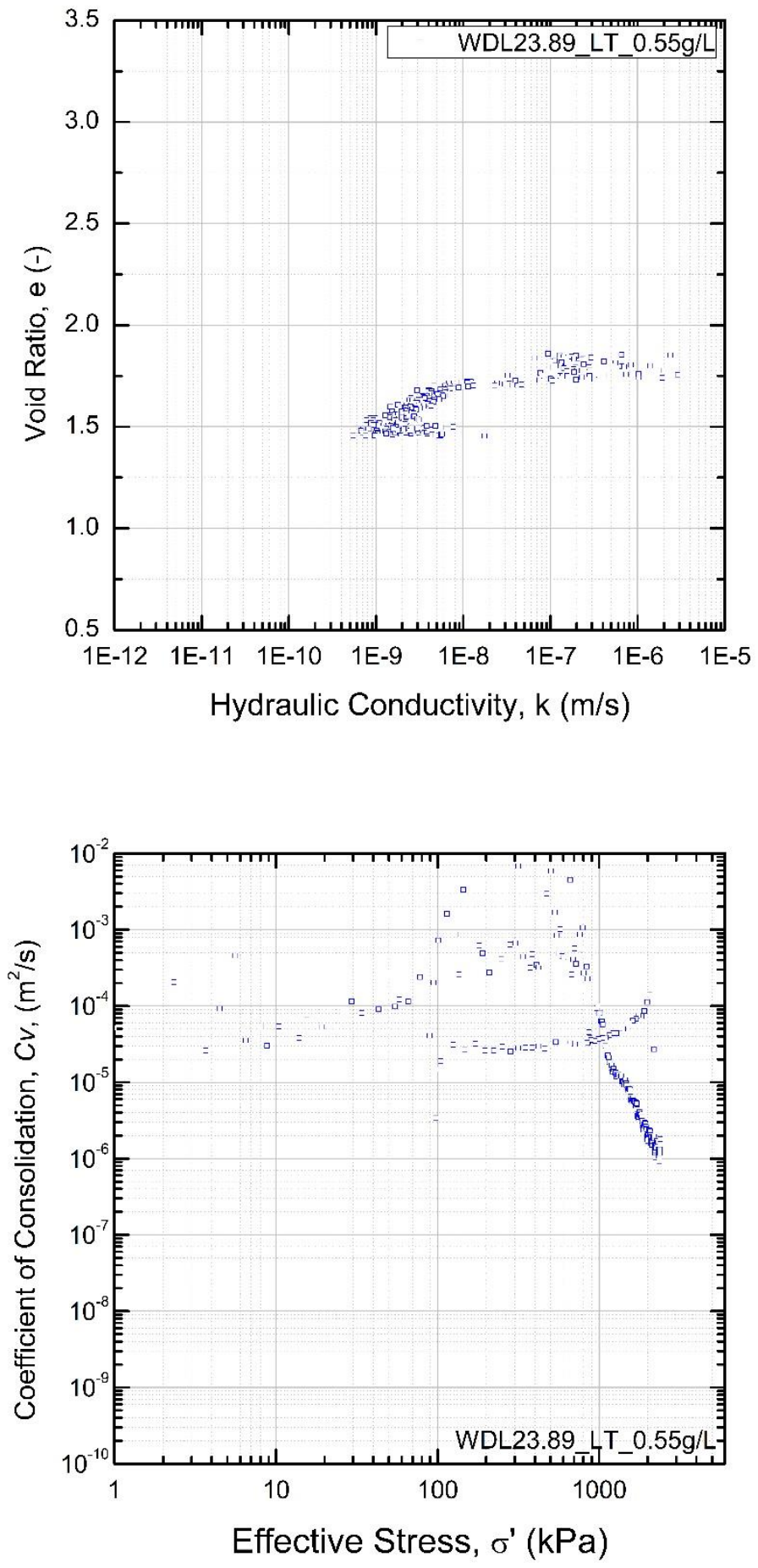

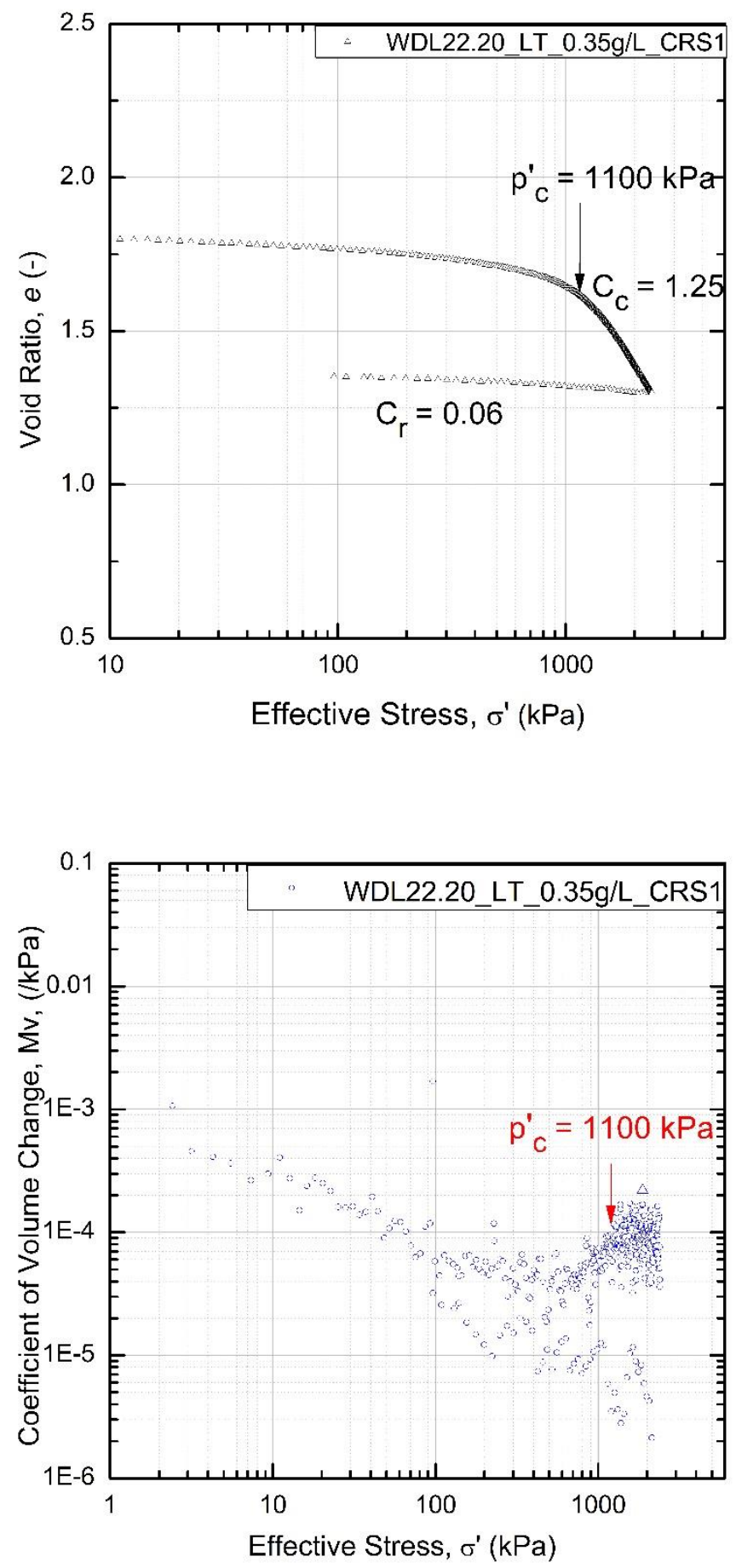


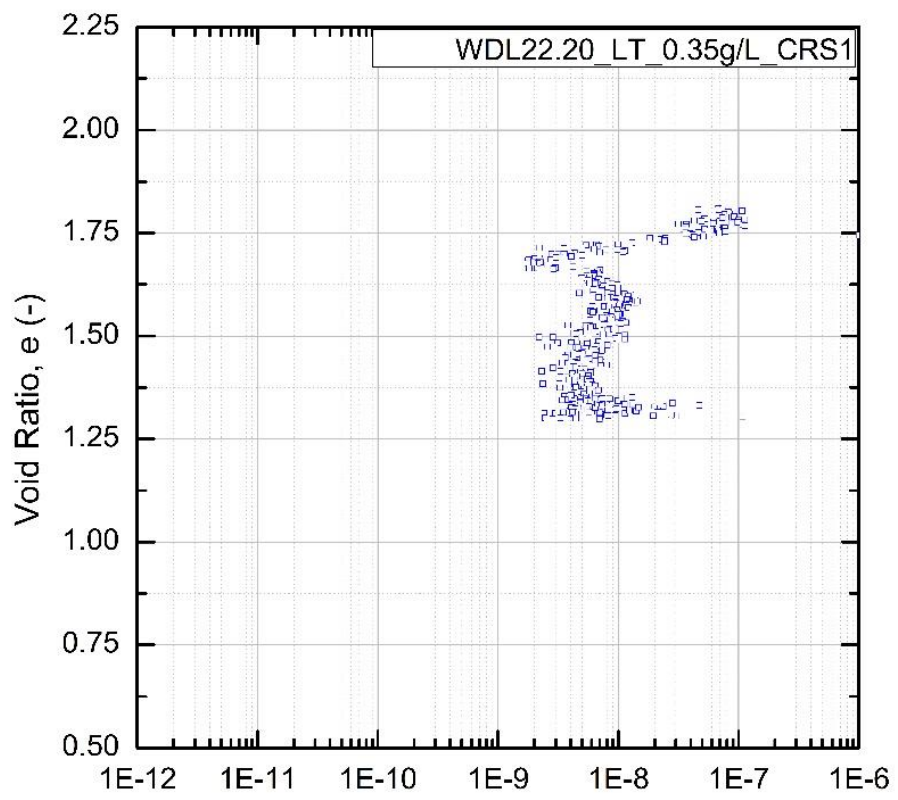

Hydraulic Conductivity, k (m/s)

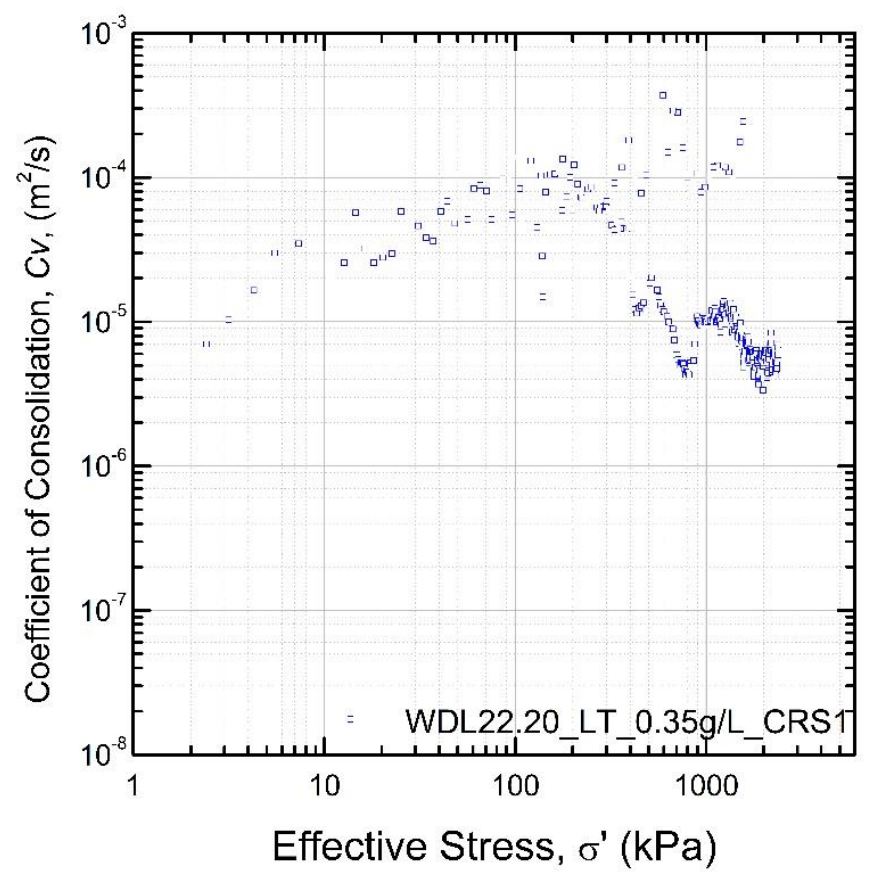




\section{REFERENCES}

ACI230.1R-90, 1990. State-of-the-Art report on soil Cement. ACI Material Journal, 87 (4).

Adam , A. L., 2011. Laboratory Evaluation of the Constant Rate of Strain and Constant Head Techniques for Measurement of the Hydraulic Conductivity of Fine Grained Soil, Massachusetts: Massachusetts Institute of Technology.

Ahmad, A., 2018. LEACHING IMPACT ON COMPRESSIBILITY OF UNTREATED AND CEMENT-TREATED CHAMPLAIN SEA CLAY, Toronto: Ryerson University.

Åhnberg, H., 2006. Strength of Stabilised Soils, Linköping: Swedish Geotechnical Institute Lund University.

Amin, D., 2015. Triaxial testing of lime/cement stabilized clay, s.1.: KTH Royal Institute of Technology.

Amin, D., 2015. Triaxial Testing of Lime/Cement stabilized Clay, s.l.: KTH Royal Institute of Technology.

Anon., 2007. Canadian Foundation Engineering Manual. In: Rock, Identification And Classification Of Soil And Rock. Vancouver: The Canadian Geotechnical Society.

Anon., 2013. FHWA. McLean(Virginia): Federal Highway Administration.

Baker, S., 2000. Deformation behaviour of Lime/Cement Column Stabilized Clay, Linköping: Swedish Deep Stabilization Research Centre Chalmers University of Technology.

Bergado, D., Anderson, L., Miura, N. \& Balashubramanium, A., 1996. Soft Ground Improvement In Lowlands and Other Environments. New York: ASCE Press.

Bergado, D. T., Ahmed, S., Sampaco, C. L. \& Balasubramaniam, A. S., 1990. SETTLEMENTS OF BANGNA-BANGPAKONG HIGHWAY ON SOFT BANGKOK CLAY. Volume 116, pp. 36-155.

Bjerrum, L., 954. Geotechnical properties of Norwegian marine clays. Geotechnique, pp. 49-69. 
Bolton, M. W., 2014. Soil Improvement Using Optimized Cementious Material Designs, s.l.: Griffith University.

Bruce, D., 2000. An Introduction to the Deep Soil Mixing Methods as Used in Geotechnical Applications, s.1.: U.S. Department of Transportation Federal Highway Administration.

Clementino, R. V., 2005. Discussion of "An oedometer test study on the preconsolidation stress of glaciomarine clays". NRC Canada.

Duhaime, F., Benabdallah, E. M. \& Chapuis, R. P., 2013. The Lachenaie clay deposit: some geochemical and geotechnical properties in relation to the salt-leaching process. Volume 50.

Eden, W. J. \& Crawford, C., 1957. Geotechnical properties of Leda Clay in the Ottawa area, Ottawa: The Division Of Building Research Ottawa, NRC.

Eden, W. J. \& Crawford, C. B., 1957. Geotechnical Properties of Leda Clay in the Ottawa Area.

FANG, Z., 2006. PHYSICAL AND NUMERICAL MODELLING OF THE SOFT SOIL GROUND IMPROVED BY DEEP CEMENT MIXING METHOD, s.1.: s.n.

HAYNES, J. E., 1975. Mineralogy and bonding components of Leda clay at four sites, London: The University of West Ontario.

Holtz, R. D., Kovacs, W. D. \& Sheahan, T. C., 2010. An Introduction to Geotechnical Engineering. 2nd ed. s.1.:Pearson.

HONG, Z., LIU, S. \& NEGAMI, T., 2005. Strength Sensitivity of Marine Ariake Clays. Volume 23, pp. 221-233.

Horpibulsuk, S. et al., 2012. Strength development in blended cement admixed saline clay. pp. 4452.

Huang, J. \& Han, J., 2010. Two-dimensional parametric study of geosynthetic-reinforced columnsupported embankments by coupled hydraulic and mechanical modeling. Computers and Geotechnics, pp. 638-648. 
Ismael, N. F., 1993. Laboratory and field leaching tets on coastal salt-bearing soils. Journal of Geotechnical Engineering, pp. 453-470.

J.K., T., 1974. A laboratory investigation of the effect of leaching on the compressibility and shear strength of Norwegian marine clays. Geotechnique 24. No 2, pp. 155-173.

Kim, Y.-T. \& Do, T.-H., 2009. Effect of leaching on the compressibility of Busan clay. KSCE Journal of Civil Engineering, pp. 608-737.

Kitazume, M. \& Terashi, M., 2012. The Deep Mixing Method, Tokyo: CRC Press.

Liao, H., T.C., K., M.S., C. \& Z.C., W., 1992. Grouting for retaining wall movement control of a deep excavation in soft clay. pp. 403-416.

Li, B., Kirstein, A., Gurpersaud, N. \& Liu, J., 2016. Deep Soil Mixing for Ground Improvement of Champlain Sea Clay Preliminary Experimental Investigation, s.1.: s.n.

Li, S., Kirstein, A., Gurpersaud, N. \& Liu, J., 2016. Experimental investigation of cement mixing to improve Champlain Sea clay. Vancouver, GEOVANCOUVER.

Liu, J., Shi, C., Afroz, M. \& Kirstein, A., 2017. Numerical Investigation of Long-Term Settlement, Toronto: s.n.

Locat, J., Berube, M. \& Choquette, M., 1990. Laboratory Investigation on the Lime Stabilization of Sensitive Clays: Shear Strength Development. Canadian Geotechnical Journal, pp. 294-305.

Mitchell, J., 1976. The properties of Cement-stabilized soils, Leura, Australia: Residential Workshop on Materials and Methods For Low Cost Road, Rail, and Reclamation Works.

Mosallamy, M. E., Salloum, T., Hassan, P. \& Liu, J., 2014. Numerical simulation of deformation. s.l., GeoRegina2014.

Muhunthan, B. \& Sariosseiri, F., 2008. Interpretation of Geotechnical Properties of Cement Treated Soil, s.l.: The Federal Highway Administration U.S. Department of Transportation. 
Nader, A., 2014. Engineering Characteristics of Sensitive Marine Clays - Examples of Clays in Eastern Canada, Ottawa: s.n.

Nataraj, T., Murthy, B., Vatsala, A. \& Joshi, R., 1990. ANALYSIS OF COMPRESSIBILITY OF SENSITIVE SOILS. Journal of Geotechnical Engineering, Volume 116.

PATHIVADA, S. P., 2005. EFFECTS OF WATER-CEMENT RATIO ON DEEP MIXING TREATED EXPANSIVE CLAY CHARACTERISTICS, s.1.: THE UNIVERSITY OF TEXAS AT ARLINGTON.

Penner, E. \& Burn, K. N., 1977. Review of engineering behaviour of marine clays in Eastern Canada. CAN. GEOTECH. J. , pp. 269-288.

Quang, N. D. \& Chai, J. C., 2015. Permeability of lime- and cement-treated clayey soils.

Quigley, R. M., Haynes, J. E., Bohdanowicz, A. \& Gwyn, Q., 1985. Geology, Geotechnique, Mineralogy and Geochemistry of Leda Clay from Deep Boreholes, s.1.: Ontario Geological Survey.

Quinn, P. E., 2013. Landslide susceptibility in sensitive clay in eastern Canada:. International Journal of Image and Data Fusion, p. 70-96.

Rochelle, L., P., C., J. \& Lefebvre, G., 1970. Regional geology and landslides in the marine clay deposits of Eastern Canada. Canadian Geotechnical Journal, pp. 145-157.

Salloum, T., Bhardwaj, V., Hassan, P. \& Cragg, C., 2009. Deformation Performance of Waba Dam, s.l.: GeoHalifix.

Scott, J. S., 2003. A review of the geology and geotechnical characteristics of Champlain Sea Clays of the Ottawa River Valley with reference to slope failures, Ottawa: Geological Survey of Canada.

Taha, A. M., 2010. Interface Shear Behavior of Sensitive Marine Clays - Leda Clay, Ottawa: s.n.

Torrace, J. K., 1974. A laboratory investigation of the effect of leaching on the compressibility and shear strength of Norwegian marine clays. Geotechnique 24. No 2, pp. 155-173. 
Torrace, J. K., 1975. On the Role of Chemistry in the Development and Behavior of the Sensitive Marine Clays of anadaan d Scandinavia. CAN. GEOTECH. J. VOL. 12, 1975.

Uddin, K., Balasubramaniam, A. \& Bergado, D., 1997. Engineering behavior of cement-treated Bangkok soft clay. pp. 89-119.

Woo, S. \& Moh, Z., 1977. Effect of leaching on undrained shear strength behaviour of a sedimented clay, Taipei: MAA Publishing Company.

Yafrate, N. J. \& DeJong, J. T., 2006. Interpretation of Sensitivity and Remolded Undrained Shear Strength with Full.

YONG, R. N., ELMONAYERI, D. S. \& CHONG, T., 1985. THE EFFECT OF LEACHING ON THE INTEGRITY OF A NATURAL CLAY. Engineering Geology, 19 November, Volume 21, pp. 279-299.

Yu, Y., Pu, J., Ugai, K. \& Hara, T., 1999. A Study on the Permeability of Soil-Cement Mixture. Volume 39, pp. 145-149. 